Universidade de São Paulo

Faculdade de Filosofia, Letras e Ciências Humanas

Departamento de História

Programa de Pós-Graduação em História Social

\title{
Pequenos Poemas em Prosa
}

\section{Vestígios da leitura ficcional na infância brasileira, nas décadas de 30 e 40.}

Patricia Tavares Raffaini

Tese apresentada ao Programa de PósGraduação em História Social do Departamento de História, da Faculdade de Filosofia, Letras e Ciências Humanas da Universidade de São Paulo, para a obtenção do título de Doutor em História.

Orientador: Prof. Dr. Elias Thomé Saliba

São Paulo

2008 
Ao Fra e à Renata 


\section{Resumo}

Durante as décadas de 30 e 40, o escritor Monteiro Lobato reuniu e preservou inúmeras cartas enviadas a ele por crianças leitoras, nelas estão registradas muitas opiniões sobre sua obra além de considerações sobre a vida das próprias crianças e como elas viam o mundo a seu redor. A presente pesquisa pretende analisar através dessa fonte documental qual era a recepção da obra infantil de Lobato, naquele período. Abordaremos ainda a circulação dos livros de Lobato assim como as maneiras de leitura praticadas na infância. Como forma de ampliarmos a percepção sobre a recepção da leitura ficcional no período, utilizamos também uma outra rica fonte documental: O jornal produzido pelas crianças freqüentadoras da Biblioteca Infantil Municipal, em São Paulo. Esse jornal intitulado A Voz da Infância veiculava resenhas e comentários de livros escritos pelas crianças, possibilitando assim uma compreensão mais abrangente da recepção da literatura infanto-juvenil, pois mencionava os autores mais lidos no período.

Palavras-chave: Infância, Epistolografia, Leitura na Infância, Literatura Infanto-Juvenil, História da Leitura, Monteiro Lobato 


\begin{abstract}
The writer Monteiro Lobato, during the 30's and 40's, reunited and preserved a number of letters sent to him by children who read his books. Those letters had registered many opinions about his work, beyond statements about those kids way of life and their environment. Analyzing this corpus this research wants to show how children realize Lobato's children books, in those days, besides this books circulation and the reading manners in childhood. To enlarge the perception of the literary reading reception in that period, we can use another documental source: a newspaper, named: A Voz da Infância, produced by frequently users, children who went to Biblioteca Infantil Municipal in São Paulo, Brazil. In this newspaper children wrote minutes descriptions and comments about books mentioning authors who had more books reads in the period, making possible a large perception about children literary reading reception.
\end{abstract}

Key-words: Childhood, Epistolography, Readings in Childhood, Children’s Literature, Reading History, Monteiro Lobato 


\section{Sumário}

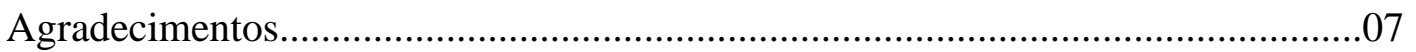

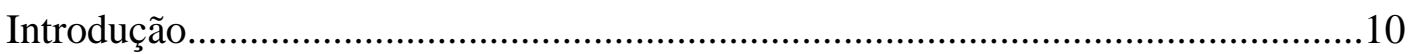

Como trabalhar com uma documentação produzida por crianças? ........................18

Livros para infância $\quad$...................................................................................29

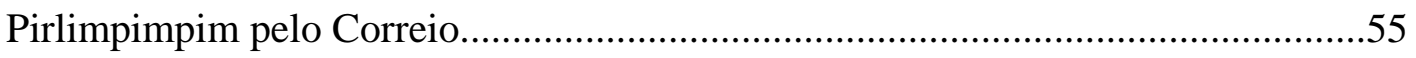

O Jornal “A Voz da Infância”.................................................................................146

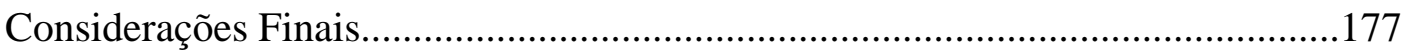

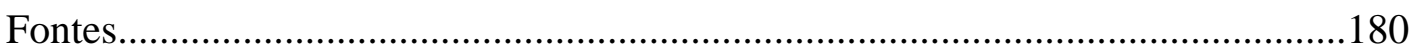

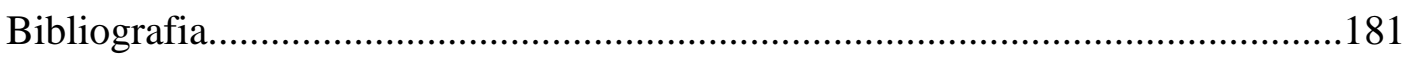


"A melhor coisa do mundo é ser criança. A segunda melhor coisa do mundo é escrever sobre ser criança”

J. M. Barrie 


\section{Agradecimentos}

Gostaria, em primeiro lugar, de agradecer ao Prof. Elias Thomé Saliba, que desde o mestrado orienta minha vida acadêmica, compartilhando informações importantes, emprestando livros, sendo um leitor atento e perspicaz de toda a minha produção. Acredito que, depois de todos esses anos, uma das lições mais importantes apreendidas é a de que, juntamente com a seriedade da pesquisa, devemos sempre manter o bom humor. Posso dizer que, durante todo o desenrolar da pesquisa, a máxima de Montaigne foi seguida tornando todo o percurso mais leve e produtivo.

Devo também agradecer aos professores Nelson Schapochnik, da Faculdade de Educação, e Gabriela Pellegrino Soares, do Departamento de História, pelas críticas e sugestões oferecidas na banca de qualificação, assim como pelo empréstimo de livros e conversas motivadoras e espero ter, em parte, desenvolvido alguns dos pontos levantados naquela ocasião. Ao Prof. Nicolau Sevcenko agradeço as conversas sempre interessantes e generosas resultantes do convívio desde a graduação. À Profa. Maria dos Prazeres S. Mendes agradeço a oportunidade de percorrer as obras literárias infanto-juvenis sob outras perspectivas.

Meu interesse por Monteiro Lobato data de quase duas décadas: tudo começou em uma disciplina “História da Arte no Brasil”, ministrada pelo Prof. Tadeu Chiarelli, que havia terminado sua pesquisa sobre o Lobato crítico de arte. Foi ele quem me estimulou, no início da graduação, a ler a Barca de Gleyre, possibilitando, assim, ver Lobato de um outro ponto de vista. Muitos anos depois Celina Kuniyoshi convidou-me a ajudá-la em uma pesquisa que se transformaria em uma exposição sobre Lobato, foi então que entrei em contato, pela primeira vez, com as cartas que as crianças escreveram para o autor e de onde surgiu a idéia inicial deste trabalho. 
Durante todo o percurso da pesquisa muitos foram os que ajudaram em todas as instituições pelas quais passei. No Arquivo do Instituto de Estudos Brasileiros (IEB/USP) sou imensamente grata a Izilda, Cecília, Maria Helena, Mônica e Cinthia, que sempre me auxiliaram nas buscas pelos documentos, e que também tantas vezes me ouviram falar da pesquisa. Ainda no IEB devo agradecer às bibliotecárias e aos técnicos em informática que digitalizaram parte do material iconográfico reproduzido neste trabalho.

Na Biblioteca Infanto-Juvenil Monteiro Lobato, em São Paulo, tive a agradável surpresa de não só encontrar funcionários competentes e solícitos, mas pessoas que se tornaram amigos queridos, meu muito obrigado a: Ana Lúcia Brandão, Kazue, Nério, Sônia, Kelma, Cecília, Oiram e Azilde. Fica também registrado um agradecimento especial à D. Hilda J. Villela Merz, sem a qual o acervo histórico da Biblioteca praticamente não existiria e também pelas conversas tão interessantes.

Aos funcionários da Biblioteca da Faculdade de Filosofia, Letras e Ciências Humanas (FFLCH/USP) agradeço pela atenção com que sempre me receberam dando o apoio necessário para que a pesquisa se realizasse. Não posso deixar de agradecer também aos funcionários da Seção de PósGraduação do Departamento de História, sobretudo Oswaldo Medeiros, pelo trabalho indispensável e por facilitarem muito a vida acadêmica.

Alguns amigos foram presenças muito especiais durante a pesquisa, mas principalmente na reta final da redação da tese devo agradecer à Marly A. Shibata que fez uma revisão cuidadosa e também a preciosa ajuda com as imagens, ao Janes Jorge agradeço pela leitura atenta e pelas sugestões feitas ao texto e ao Carlos Avelino A. Camargo pela feitura da capa. No Departamento de História encontrei amigos queridos, todos eles também orientandos do Prof. Elias, à Camila Rodrigues, Karícia, Leandro, Margareth e Camila Koshiba agradeço as conversas e indicações.

Outros amigos devem ser lembrados, pois contribuíram muito, sendo sempre atenciosos e solidários: Acácio, Sílvia, Paulo, Tânia, Débora, Tâmara, Fred, Malu, Joviniano, Cacá e Theo.

Ao $\mathrm{CNPq}$ agradeço pelo apoio fornecido por meio de bolsas de estudo, sem as quais esta pesquisa seria inviável. 
Aos meus pais, Luis Carlos e Maria Tereza, agradeço a dedicação e o apoio em todos os momentos da minha vida e, sobretudo, nesses últimos anos, nos quais além de pais exemplares foram também avós ativos e carinhosos. Aos meus irmãos e cunhados agradeço também pelo apoio e carinho, ao Edu e a Lili, que me receberam no Rio, a Pri e ao Rafael e a Ale e ao Ricardo, obrigada. Aos meus sobrinhos, grandes e pequenos, todos meninos: Daniel, Tomás, Lucas, Tiago, Dudu, Rafael e João Pedro, agradeço a oportunidade de conviver e entender melhor a infância.

Ao Fra e à Renata essa obra é dedicada porque, do início até o final, vocês acompanharam todo o trajeto, me ouvindo falar de crianças e de livros de antigamente, e sem saber me ajudando com seu amor e carinho. 


\section{Introdução}

Em maio de 1946, Monteiro Lobato escreve à amiga Marina Andrada Procópio de Carvalho enviando um caderno de anotações com idéias e rascunhos feitos, provavelmente, a partir de 1917, além de um conjunto de mais de trezentas cartas enviadas a ele por crianças e jovens leitores. $\mathrm{O}$ autor se mudava para Buenos Aires e pretendia lá ficar por um bom tempo; fazia, então, uma organização do seu arquivo pessoal e de sua biblioteca, encarregando tanto Marina Andrada como Edgard Cavalheiro de preservarem parte de sua documentação. As cartas enviadas pelos leitores, principalmente as escritas pelas crianças, eram seu tesouro particular; por meio delas Lobato percebia que sua produção surtia efeito e estabelecia com as crianças um diálogo muito importante. Sobre o Lobato epistológrafo, Marina escreve no Prefácio ao livro Prefácios e Entrevistas:

“As manhãs ele as consagra à sua correspondência, sobretudo a infantil. E o carinho e o respeito que dedica à correspondência com as crianças toma um caráter ritual religioso. É um dever sagrado. Penso que tudo poderá acontecer a Lobato, menos deixar de responder uma cartinha de criança. (...)””

Já numa entrevista para a Revista Diretrizes, o repórter comenta sobre as mesmas cartas:

“As cartas de literatos a Lobato enchem toda uma canastra. Mas há outras, muito mais numerosas, que se empilham aos montes; as cartas de todos os dias, que invariavelmente, ele recebe das crianças do Brasil. Trazem elas, geralmente, o pedido de um retrato ou de um livro.(...)

Monteiro Lobato diz que só isso, só as cartas que as crianças brasileiras lhe enviam todos os dias, compensa escrever literatura

\footnotetext{
${ }^{1}$ CARVAlHO, Marina Andrada Procópio de. Prefácio. In: MONTEIRO LOBATO. Prefácios e Entrevistas. 8.ed. São Paulo: Ed. Brasiliense, 1957. p. xiii.
} 
infantil. Ele guarda com amor as cartas dos meninos. Tanto assim que todas elas há muito que se encontravam catalogadas e numeradas, trabalho que somente agora Lobato está tendo com as cartas de escritores e artistas adultos que tem recebido nestes vinte e cinco anos de literatura e trabalho." 2

Outro testemunho desse cuidado que Lobato possuía ao guardar as cartas enviadas pelas crianças pode ser percebido numa resposta enviada a um leitor já crescido que, tendo se correspondido com o autor na infância, retomava quase dez anos depois o contato. É assim que Lobato inicia a carta:

"Gilson

Tenho aqui todas as suas cartinhas de menino, como as de todos quanto me escreveram e me escrevem. Centenas, e muito preciosas - e vai para o 'filé' das preciosas a sua de 24 do corrente $(\ldots)^{\text {3 }}$

Era essa preciosa correspondência que ele deixava sob a responsabilidade de Marina e compreendia os anos de 1932 a 1946, período que corresponde aos anos que Lobato morou em São Paulo, entre sua estada como adido cultural em Nova York e o ano de sua mudança para Buenos Aires. As cartas haviam sido enviadas por crianças de todo o Brasil e mesmo do estrangeiro e estabeleciam com o autor um diálogo que versava sobre muitos assuntos. Em sua maioria as cartas comentavam as obras lidas do autor, mas também faziam os pedidos mais variados: encontros pessoais, traduções de outros livros, e até mesmo um pouco de pó do pirlimpimpim; expressavam ainda opiniões políticas e muitos outros assuntos como veremos a seguir.

Foi por meio da leitura desta correspondência entre as crianças e Lobato que surgiu nosso desejo de trabalhar, de uma forma mais ampla, com a recepção da obra literária infantil. Assim, um dos objetivos deste trabalho é investigar como as crianças liam, quais eram suas preferências, que opinião tinham sobre aquilo que liam e quais os possíveis significados que essa leitura possuía em suas vidas. Outro aspecto a ser analisado pela pesquisa é

\footnotetext{
${ }^{2}$ MONTEIRO LOBATO. Um governo deve sair do povo como o fumo sai da fogueira. In : Prefácios e entrevistas. 8.ed.São Paulo: Ed. Brasiliense, 1957. p. 155-167.

${ }^{3}$ Resposta de Monteiro Lobato a Gilson. S. P. 30/03/1943. In: DEBUS, Eliane. Monteiro Lobato e o leitor, esse conhecido. Itajaí; Florianópolis: Univali/Ufsc, 2004. p. 260.
} 
como essa relação, por meio das cartas entre o escritor e o leitor, repercutiu e, eventualmente, até transformou a produção literária de Lobato.

As crianças expressavam suas opiniões sobre a leitura não somente pelas cartas, mas também por meio de artigos e resenhas em jornais infantis. Dessa forma outra fonte importante para esta pesquisa foi o jornal $A$ Voz $d a$ Infância, publicado pelas crianças frequentadoras da Biblioteca InfantoJuvenil, mais tarde intitulada Monteiro Lobato. Essa Biblioteca foi inaugurada em 1936, na cidade de São Paulo, como uma das bibliotecas da rede de bibliotecas imaginada por Rubens Borba de Morais e Mário de Andrade, e ficou sob a direção de Lenyra Fraccaroli. Por meio da leitura do jornal que começou a ser publicado mensalmente em julho de 1936 e que continuou sem interrupções até 1948, poderemos verificar quais autores eram os mais lidos e qual a opinião dos leitores destes livros.

Paralelamente à análise das opiniões das crianças sobre o que liam, esta pesquisa pretende refletir sobre como a criança articulava uma escrita sobre aquilo que lia. Como seriam formuladas as opiniões sobre a leitura? Quais as especificidades da escrita infantil? Não podemos unicamente analisar a apreciação da obra pelas crianças sem nos atermos às formas pelas quais elas faziam essa apreciação. Em inúmeras cartas vemos que a coloquialidade da escrita está muito presente, no entanto quando as crianças escrevem artigos e resenhas no jornal “A Voz da Infância” essa já não é a forma mais utilizada. Assim vemos que a criança domina um repertório de possibilidades da escrita e que as utiliza conforme a conveniência. Essas análises possibilitam a compreensão mais aprofundada não apenas de como a criança lia, mas também de como ela escrevia sobre o que havia lido.

Na área da História da Leitura, o leitor é, muitas vezes, difícil de ser compreendido, pois as fontes frequentemente são indiretas, e possibilitam uma visão um tanto enevoada de como a leitura era realizada, e o que pensava esse leitor. Em alguns momentos temos um corpo documental que possibilita um aprofundamento maior como no estudo de Robert Darnton ${ }^{4}$ sobre Jean Ranson, um leitor do século XVIII. Mas como o próprio historiador comenta, no mesmo trabalho: dossiês com correspondência de

\footnotetext{
${ }^{4}$ DARNTON, Robert. Os leitores respondem a Rousseau. In: o Grande Massacre de gatos. e outros
} episódios da história cultural francesa. 4.ed. Rio de Janeiro: Graal. 1986. p. 277-328. 
leitores não são fáceis de encontrar em arquivos. No caso do leitor analisado por Darnton temos as cartas enviadas a uma casa editorial, que nos fornecem um perfil de seus interesses e seus comentários sobre as obras lidas. Correspondências enviadas por leitores a escritores são ainda mais raras e, como veremos no caso específico de Lobato com as crianças, ultrapassam em muito a relação pela via da tinta e do papel.

Tendo, então, em mãos um corpo documental que possibilitava uma compreensão aprofundada de como a leitura acontecia na infância, outras questões se colocaram: como trabalhar com uma documentação que foi produzida por leitores que eram crianças? Quem eram essas crianças leitoras? Como o historiador deve trabalhar com uma documentação produzida exclusivamente por crianças e jovens? Que indícios as cartas dão sobre como essas crianças percebiam sua própria infância?

Em um primeiro momento começamos a ver essa criança como um adulto em miniatura; no entanto, ao utilizarmos essa perspectiva, a leitura dos documentos ficava empobrecida, e no decorrer da pesquisa se tornava evidente que essas crianças não eram adultos em miniatura, não eram tratadas como tal por Lobato, nem tampouco se percebiam como tal. Enxergando as crianças como adultos em miniatura, as peculiaridades da escrita e do pensar da criança se perdiam e era essa especificidade que dava um colorido e um sabor especial a essa correspondência. Não era possível compreender os autores das cartas, nem o que achavam do que liam, sem compreender de forma mais aprofundada o que chamamos de infância ou ser criança.

Logo em seguida pensamos em trabalhar com o universo infantil em oposição, ou em paralelo ao universo adulto: neste caso a criança ainda não é adulta, mas seu cotidiano é praticamente moldado por formas de imitação do mundo adulto. Dessa forma quando a criança “brinca de casinha”, o que ela está fazendo é uma imitação e uma preparação para quando ela entrar no mundo adulto. Assim, poderíamos ver na escrita das cartas um preparo para a vida adulta, ou então crianças imitando uma prática freqüente da vida adulta. No entanto, essa visão da infância como um vir a ser, como seres ainda não sociais, e que necessitam passar pela socialização - muitas vezes pensada como algo proveniente somente do contato com adultos - acarreta certos problemas, já que impossibilita uma compreensão do universo infantil em 
sua plenitude, na sua peculiaridade. Por exemplo, essa visão da infância como um vir a ser impossibilita a análise da capacidade de elaboração da realidade em outros parâmetros que a criança possui. Assim, mesmo quando participa de brinquedos que parecem imitar a vida dos adultos as crianças não estão imitando, mas recriando através da brincadeira um outro mundo, com uma lógica muito peculiar.

No trabalho com as cartas de crianças era necessário compreender o universo mágico e onírico que aparecia na documentação de forma autêntica, e não do ponto de vista do adulto, que já não participa da mesma forma deste universo. $^{5}$ Ao mesmo tempo não poderíamos perder de vista que mesmo tendo sido escritas por crianças, havia em muitas cartas a construção de uma imagem pessoal que se queria mostrar ao escritor. Por vezes as crianças teciam comentários sobre sua própria condição, realizando assim, como qualquer correspondente, também uma escrita de si, embora com algumas particularidades.

Foi então necessário recorrer a uma bibliografia que abordasse e definisse de forma mais adequada a infância, para os nossos propósitos. E que analisasse a criança em suas particularidades, respeitando-a assim como o próprio Lobato fazia em sua correspondência, sem falar, obviamente, em sua produção literária. Em um texto escrito originalmente para ser uma conferência de proteção à infância ${ }^{6}$ Lobato nos fala de duas formas bastante distintas de se ver a criança:

"Uma, a dos que consideram a criança como um homem em miniatura e pede que se dê a ela o mesmo alimento mental e moral que se dá ao homem, com redução apenas de dose. Critério dos farmacêuticos: para adultos, uma colher de sopa; para crianças, uma colher de chá. (...)

A outra corrente admite a criança como um ser especialíssimo, do qual o homem vai sair, mas que ainda tem muito pouco de homem. Em conseqüência, o seu alimento mental há de ser nunca uma redução da dose, mas algo especial.(...)

\footnotetext{
${ }^{5}$ Ver carta fac-símile no final do trabalho.

${ }^{6}$ Este texto foi publicado postumamente, não se sabendo se foi de fato utilizado em uma conferência ou não. Além da publicação no livro Conferências, Artigos e Crônicas, foi também publicado em um folheto comemorativo da inauguração da Biblioteca Infantil Monteiro Lobato, de Salvador, em 1948.
} 
A criança é um ser onde a imaginação predomina em absoluto. O meio de interessá-la é falar-lhe à imaginação. Vive num mundinho irreal e dêle só sai, para aos poucos, ir penetrando no das duras e cruas realidades, quando com o natural desenvolvimento do cérebro, a intensidade imaginativa vai-se apagando."7

Lobato resume aqui toda uma ampla história das concepções sobre a criança, sendo que sua produção literária se pautará em explorar, é claro, essa segunda corrente, onde a fantasia e o prazer da leitura constituem os ingredientes principais. No entanto, mais adiante, no mesmo texto Lobato explica de que forma constrói sua obra:

“(...) Não possuo a mínima autoridade pedagógica de qualquer gênero, e tudo quanto sei de educação se resume em arruinar a exceção em favor da regra. Apesar disso escrevi uns livros que as crianças gostam de ler. E porque gostam as crianças de ler êsses livros? Talvez pelo fato de serem escritos por elas mesmas através de mim. Como as coitadinhas não sabem escrever, admito que me pedem que o faça. Mas não que o faça como quero e sim como querem elas. Há de ser assim, assim, assim - e humildemente anulo-me para dar a minha clientelazinha um produto que não lhes desagrade."8

Como veremos, essa postura de colocar a criança como um agente importante de sua criação literária pode ser encontrada na correspondência analisada e encontra ressonância na bibliografia contemporânea que trabalha com a criança como ator-social. No mesmo texto, o próprio Lobato relata a experiência de se contar uma história para uma criança, e como a criança ao escutar a história vai modificando-a, tornando-se quase sua co-autora:

"Faça-se a experiência. Conte-se uma história qualquer a uma criança. Ela a vai recebendo com reações muito dignas de estudo. Vai corrigindo-a no sentido de pô-la de acôrdo com as exigências da sua imaginação. E se o contador possui a necessária inteligência para

\footnotetext{
${ }^{7}$ MONTEIRO LOBATO. A criança é a humanidade de amanhã. In: Conferências, Artigos e Crônicas. 5.ed. São Paulo: Ed. Brasiliense, 1968. p.250.

${ }^{8}$ Idem. p. 254-255.
} 
atender a essas reações, a história modifica-se até cair em ponto de bala."9

No entanto, a atenção que Lobato dava à recepção de sua obra infantil, assim como a utilização de muitas sugestões que as crianças lhes davam, através das cartas, não deve ser supervalorizada a ponto de deixarmos de perceber que o autor tinha um projeto e veiculava suas idéias e concepções sobre o mundo, quando escrevia as aventuras que se passavam no Sítio do Picapau Amarelo. Quando afirma que a criança é diferente do adulto assim como a crisálida é da borboleta, Lobato o faz segundo um modelo de representação, e o que certamente existe por traz dessa concepção é uma idéia de infância bastante peculiar: a idéia de que a criança é diferente, mas possui autonomia de pensamento, mesmo que esse pensamento nem sempre corresponda ao padrão adulto. Outro ponto importante de ser analisado nesse discurso é a transitoriedade da infância: ela está destinada a não mais ser, a se tornar adulta, por isso o título da conferência: A criança é a humanidade de amanhã. É nessa característica efêmera da criança que Lobato aposta suas fichas. Seu projeto era tornar a literatura palatável às crianças para que elas, gostando de ler, se tornassem ao crescer um público leitor. A constituição de um público leitor era, desde o século XIX, um sonho almejado por literatos e intelectuais, sem o qual não se via a constituição de uma nação. Dessa forma, durante os anos de formação do que viria a ser o público leitor, Lobato pretendia despertar a crítica, a autonomia de pensamento, a irreverência e também o humor nesse indivíduo em formação.

As crianças produtoras da documentação, que aqui será analisada, parecem compreender e aceitar o convite de Lobato. Através das cartas emitem suas opiniões sobre as obras lidas, e também sobre outros aspectos de suas vidas. Solicitam livros, traduções, desejam estar nas aventuras com a turma do Sítio e Lobato atende seus pedidos, aproveitando com boa vontade suas opiniões. Até mesmo a forma pela qual elas se dirigem ao escritor está diretamente relacionada à maneira pela qual Lobato idealiza a criança na sua obra literária.

\footnotetext{
${ }^{9}$ Idem. p. 253.
} 
Para melhor compreendermos quem eram, e o que pensavam as crianças autoras da documentação analisada, foi necessário utilizar uma bibliografia que vê a criança e a infância sob uma outra perspectiva. É o que se fará no primeiro capítulo deste trabalho, a partir de um ensaio de revisão da extensa historiografia que trabalha com a criança.

No segundo capítulo pretende-se abordar o universo da leitura. De início faremos um panorama da produção voltada à infância, do século XVIII até as décadas iniciais do século XX, pretendendo com isso localizar melhor não só a produção de Lobato, bem como as obras, livros e revistas citadas pelas crianças na documentação analisada. Assim poderemos analisar não só o texto, mas materialmente como essas publicações eram produzidas antes e durante o período estudado.

A partir de então analisaremos, no terceiro e quarto capítulos, a documentação central desta tese: cartas e artigos escritos pelas crianças com o intuito de perceber quais obras eram as mais lidas e o porquê dessa escolha. Como as crianças realizavam essa leitura, se eram estimuladas pelos pais, se havia mediação da escola ou de bibliotecas são alguns dos pontos a serem tratados. Ainda gostaríamos de averiguar que opiniões as crianças tinham sobre o que liam, quais eram seus autores preferidos e porque o eram. Pretende-se também refletir sobre o que representava para essas crianças o ato de ler, que significado as leituras poderiam ter em suas vidas? Se a leitura era um passaporte que as levaria para longe, para um mundo imaginário, para realidades desconhecidas ou se, ao contrário, as auxiliava na compreensão de seu mundo real e cotidiano é algo que nos esforçamos por vislumbrar no decorrer desta tese. 


\title{
Como trabalhar com uma documentação produzida por crianças?
}

\author{
"Tudo é misterioso, nesse reino que o homem começa a \\ desconhecer desde que o começa a abandonar.” \\ Cecília Meireles
}

Até a década de 50, o campo de estudos sobre a criança na história era quase que inexistente. Foi com o trabalho pioneiro de Philippe Ariés, publicado em 1962, L'enfant et la vie familiale sous l'Ancien Regime que se iniciou uma reflexão sobre a infância. Esse trabalho se tornou um clássico ao afirmar que foi durante os séculos XV, XVI e XVII que veremos o aparecimento da infância como um fenômeno social. Ariés desenvolvia em seu estudo a idéia de que o mundo medieval ignorava a infância, que não existia nessa época um longo período em separado da vida adulta e que logo após os cinco ou seis anos a criança era incorporada ao ambiente de trabalho e à vida social como um todo. Essa transformação levaria também às mudanças na sociabilidade e no surgimento de um novo modelo familiar. As relações mais significativas davam-se, na opinião do historiador francês, a partir do advento da modernidade no âmbito privado e não mais no público. Dessa forma a modernidade não só criava a infância, como também inaugurava uma nova sociabilidade. As concepções de Philippe Ariés podem ser melhor entendidas se levarmos em consideração que outros autores seguiram também essa tendência historiográfica de “invenção” de inúmeros aspectos da modernidade. $^{10}$

Muitos autores criticaram a tese de Ariés, como Jean-Louis Flandrin que apesar de elogiar a documentação utilizada no trabalho alertou para a sua fragilidade metodológica. Outros autores mostraram que Ariés partia do

\footnotetext{
${ }^{10}$ Assim como Ariés mapeou a "invenção da infância", temos outros autores que se propuseram a analisar a modernidade através do aparecimento de inúmeros novos constructos, como o "homem normal”, de Foucault, os "modos a mesa" de Norbert Elias e o "romance realista” de Ian Watt.
} 
princípio de que os artistas pintavam o que a sociedade como um todo via. Assim, utilizava inúmeros registros iconográficos sem se preocupar em refletir sobre como a realidade é mediada na obra de arte. ${ }^{11}$ Outros pesquisadores ressaltaram, em suas críticas, uma velada atitude presentista no trabalho de Ariés, como D. Archard. Segundo Archard não se pode dizer que não havia infância antes da modernidade somente porque essa visão difere da anterior, a medieval. Para ele a modernidade não inventou, nem descobriu a infância, a modernidade trouxe uma transformação em como a infância era entendida, como um “outro-cultural”, como tendo uma cultura diferente da dos adultos. Assim, Ariés teria inaugurado uma forma de pensar dicotomizada e feita através de opostos entre a infância e a vida adulta. ${ }^{12}$

Mais adiante veremos como esse pensar dicotomizado dificulta atualmente uma compreensão mais adequada da infância. Alguns medievalistas aceitaram a premissa de Ariés, mas em oposição muitos trabalhos foram escritos no sentido de contestar seu trabalho criticando, entre outros fatores, sua abordagem homogeneizante e interclassista, como se tivesse existido uma única Idade Média, com uma única forma de se pensar a infância. Um destes trabalhos que se opõem ao de Ariés é o do medievalista norte-americano David Herlihy, Medievals Households ${ }^{13}$ que mostra como a infância era considerada uma etapa distinta das outras, utilizando em seu estudo leis e textos produzidos pela Igreja. Também o historiador Pierre Riché, estudando os monastérios entre os séculos VI e VIII, mostrou como uma visão específica da infância se moldava nessas instituições que recebiam muitos oblatos jovens.

“São Columbano, no final do século VI, observou que em alguns aspectos, o menino poderia ser um monge superior a um adulto, porque 'não persiste na raiva, não guarda rancor, não se delicia com a beleza das mulheres e expressa aquilo em que realmente acredita'. Outro monge ilustre, Beda, repetiu a mesma fórmula no século VIII, para dar sustentação à sua visão

\footnotetext{
${ }^{11}$ HEYWOOD, Colin. Uma história da Infância. Da idade média à época contemporânea no ocidente. Porto Alegre: Artmed, 2004. p. 23-27.

${ }^{12}$ ARCHARD, D. Children: Rights and childhood. London: RoutledgeFalmer, 1993. Citado por: PROUT, Alan. The future of childhood. Towards the interdisciplinarystudy of children. New York; London: RoutledgeFalmer, 2005. p.10.

${ }^{13}$ HERLIHY, David. Medivals Households. Harvard University Press, 1985.
} 
excepcionalmente favorável da criança, que afirmava ser boa de educar, absorvendo com fidelidade aquilo que se lhe ensinava.”14

No entanto, apesar das críticas recebidas, o trabalho de Ariés foi bem recebido, principalmente, entre psicólogos e sociólogos e vemos muitas de suas idéias sendo desenvolvidas no trabalho de Neil Postman, $O$ desaparecimento da Infância, publicado em 1982. O argumento principal de Postman defendia que assim como a infância não existia antes do período moderno, tendo sido inventada, ela também poderia desaparecer. O que, segundo o autor, estaria acontecendo durante a segunda metade do século XX, em virtude, sobretudo, da exposição das crianças aos meios de comunicação de massa. Para Postman, esse processo de desaparecimento da infância teria se iniciado com a criação da imprensa e se acelerou com o crescimento da alfabetização compulsória, pois as crianças através da escrita tiveram acesso ao que antes era exclusivo do mundo adulto. O livro de Postman recebeu muitas críticas, principalmente, por historiadores ligados ao grupo denominado New Social Studies of Childhood, que abordaremos em seguida. O comentário de Colin Heywood resume em certa medida essas críticas:

“Olhando um pouco em perspectiva, Postman surge como um observador razoavelmente perspicaz dos acontecimentos contemporâneos em termos de relações etárias, especialmente os questionamentos à suposição da inocência e da vulnerabilidade das crianças, mas seu 'desaparecimento’ parece tão exagerado quanto a 'descoberta' postulada por Ariés. Uma abordagem mais plausível seria certamente não perder de vista as formas mutantes da infância como constructo social.”15

O próprio Postman, no Prefácio escrito em 1994, continuava afirmando sua tese, de 1982, de que na sociedade norte-americana e no mundo ocidental como um todo a infância estava em vias de desaparecer. Embora transcreva, no Prefácio, cartas que havia recebido de crianças, com onze ou

\footnotetext{
${ }^{14}$ HEYWOOD, Colin. Uma história da Infância. Da idade média à época contemporânea no ocidente. Porto Alegre, Artmed, 2004. p. 34-35.

${ }^{15}$ Idem. p 45.
} 
doze anos, que haviam analisado junto com seus professores os argumentos de seu livro, parece não notar o que elas de fato expressam:

"Joseph escreveu: 'A infância não desaparece porque a gente assiste à TV. Acho que a infância é desperdiçada quando vamos a escola cinco dias na semana. Na minha opinião isso é demais. A infância é preciosa demais pra se ir à escola mais do que meia semana.' Tina escreveu: 'Quando você é criança, não tem de se preocupar seriamente com responsabilidade. As crianças tem é que brincar mais.’ John escreveu: 'Eu acho que 18 anos é a idade certa para se tornar um adulto.' Patty: 'Não acho que se um garoto de dez anos assiste a um show para adultos nunca mais possa ser criança novamente’ Andy: 'A maioria da garotada que vê filmes na TV sabe que eles não são reais.”16

Os fragmentos das cartas publicadas no Prefácio mostram que as crianças percebiam que os meios de comunicação de massa, principalmente a televisão, não tinham um papel determinista. Ao contrário de Postman, não viam a tecnologia como a causa principal da transformação, como uma via de mão única. A televisão não era a responsável pela transformação da criança em adulto, isso quem fazia era a vida social; a escola na opinião de Joseph, os dezoito anos na de John. Notamos por esses fragmentos de cartas as opiniões que as crianças tinham sobre o que é ser criança e como elas próprias definiam a infância. Para Joseph e Tina as crianças deveriam brincar mais e não ir demais à escola, a infância é vista pelas próprias crianças como um período onde não é necessário se preocupar com responsabilidades. Existe ainda uma certa autonomia e liberdade para se assistir programas de televisão e uma consciência de que o que aparece nos filmes não é real. Podemos perceber através desses fragmentos de cartas que essas visões expressas pelas crianças correspondem em certa medida ao modelo de infância norte-americano contemporâneo, onde as crianças tem um papel social determinado pela escola e também pelo tempo livre, utilizado em brincadeiras e no contato com os meios de comunicação, notadamente com os programas veiculados pela televisão.

\footnotetext{
${ }^{16}$ POSTMAN, Neil. Prefácio In: O desaparecimento da infância. Rio de Janeiro: Graphia, 2002. p.9.
} 
Uma das críticas possíveis a serem feitas ao trabalho de Postman é que, ao utilizar idéias bastante conservadoras ao definir a infância, ele comete o equívoco de pensar a mudança, a transformação da infância durante o século XX como um declínio ou como a extinção da infância. Utilizando o paradigma presencialista de infância elaborado por Ariés não consegue enxergar outras possibilidades e desenvolvimentos para este fenômeno. Assim como também supervaloriza o avanço tecnológico, não levando em consideração que o acesso a essas tecnologias são muito diferentes, dependendo das circunstâncias sociais e econômicas, e não pode ser visto como uma via de mão única, onde a tecnologia tudo determina. O autor termina o Prefácio comentando as cartas das crianças: “Há é claro, muita coisa a aprender com esses comentários mas para mim sua lição principal é que as próprias crianças são uma força na preservação da infância."17

Postman certamente acertaria mais em sua análise se conseguisse enxergar nas crianças seres completos, porém diferentes, capazes de analisar, de opinar, por vezes de forma muita acertada, sobre sua própria vida, detentores de uma forma de ver sua própria infância que está em consonância com a da sociedade na qual vivem.

Deste modo, para trabalhar com a documentação escrita pelas crianças, foi necessário recorrer a uma abordagem proveniente da antropologia, especificamente da vertente que trabalha com as idéias de Clifford Geertz que pensa a cultura como um sistema simbólico que dá sentido as experiências na sociedade. Dessa forma a criança pertence e cresce em um determinado sistema simbólico que está em constante transformação, transformação na qual a própria criança pode atuar. Assim buscamos inspiração num repertório teórico que possibilitasse entender o universo infantil não como algo em separado, marcado pelas dicotomias: adulto/criança, natureza/cultura, incompetente/ competente, entre outras. Segundo Clarice Cohn, as diferentes idéias sobre a criança surgem a partir das concepções que os adultos constroem, e elas são estabelecidas em oposição ao mundo adulto, são idéias em negativo. Com esse olhar, para essa autora somente reafirmamos uma cisão, uma grande divisão entre o mundo adulto e o das crianças.

\footnotetext{
${ }^{17}$ Idem. p. 9.
} 
“(...) precisamos nos desvencilhar das imagens preconcebidas e abordar esse universo e essa realidade tentando entender o que há neles, e não o que esperamos que nos ofereçam. Precisamos nos fazer capazes de entender a criança e seu mundo a partir do seu próprio ponto de vista. E é por isso que uma antropologia da criança é importante. Ela não é a única disciplina científica que elege esse objeto de estudo: a psicologia, a psicanálise e a pedagogia têm lidado com essas questões há muito tempo. Mas é aquela que, desde seu nascimento, se dedica a entender o ponto de vista daqueles sobre quem e com quem se fala, seus objetos de estudo.(...) a grande contribuição que a antropologia pode dar aos estudos das crianças: a de fornecer um modelo analítico que permite entendê-las por si mesmas; a de permitir escapar daquela imagem em negativo, pela qual falamos menos das crianças e mais de outras coisas (...)”18

É necessário dessa forma perceber a infância e as crianças como objetos legítimos de estudo por si mesmas, e não como seres incompletos, a serem socializados. É importante estudar e compreender o ponto de vista que elas possuem sobre o mundo no qual se inserem, e para isso a fonte documental na qual trabalhamos é um meio privilegiado. Assim, a criança passa a ser vista como um ser social completo, que participa da vida social de maneira plena, ela mesma produzindo cultura assim como todos em uma sociedade.

"Quando a cultura passa a ser entendida como sistema simbólico, a idéia de que as crianças vão incorporando-a gradativamente ao aprender 'coisas’ pode ser revista. A questão deixa de ser apenas como e quando a cultura é transmitida em seus artefatos (sejam eles objetos, relatos ou crenças), mas como a criança formula um sentido ao mundo que a rodeia. Portanto, a diferença entre as crianças e os adultos não é quantitativa, mas qualitativa: A criança não sabe menos, sabe outra coisa.”19

${ }^{18}$ COHN, Clarisse. Antropologia da Criança. Rio de Janeiro: Jorge Zahar Ed., 2005. p.8-9.

${ }^{19}$ Idem. p.33. 
Estar atento a como a criança formula um sentido ao mundo que a rodeia e que opiniões tem sobre esse mundo pode ser bastante revelador das formas de pensar. Formas essas por vezes opostas às que o adulto possui. Em um relato publicado no prefácio escrito por P. J. Stahl, à obra Les Contes de Perrault, com desenhos de Gustave Doré, publicada em 1883, vemos como o autor, em meados do séc. XIX, se admira ao contar a história de Chapeuzinho Vermelho a uma criança de quatro anos. Sua surpresa vem do fato da criança ao invés de se assustar com o lobo, que na versão de Perrault devora Chapeuzinho comenta ao final da história ser o lobo muito bonzinho. Stahl fica estarrecido com o comentário, não conseguindo entender o que se passava na cabecinha da pequena ouvinte, pergunta então porque acredita a criança ser o lobo bonzinho, a resposta é ainda mais perturbadora, “ele não havia comido o bolo”. Frente a essa resposta o autor retruca que o lobo havia devorado tanto a menina como sua avó, e isso era terrível. A menina impassível diz: “O lobinho estava com muita fome”. Toda a cena e a inusitada resposta da menina só são explicadas pela mãe, que conta para o autor que a menina já estava há quarenta e oito horas de dieta. Não podendo se alimentar a menina se solidarizou com o lobo e como a mãe havia prometido, assim que acabasse o período de dieta daria um bolo à menina, ela, com sua pouca idade, se preocupou ao ouvir atentamente a história, mais com o bolo prometido, que na sua imaginação poderia ser o mesmo da história. ${ }^{20}$

Esse relato nos alerta para a necessidade de tentar compreender a criança a partir de seu próprio ponto de vista. Sem esse olhar reduziríamos a experiência infantil, não conseguiríamos perceber a riqueza e a peculiaridade de sua forma de pensar. Como já se disse: jogaríamos fora o bebê junto com a água do banho, e neste caso específico, quase que literalmente!

Roger Bastide, no Prefácio à obra As trocinhas do Bom Retiro, de Florestan Fernandes, faz considerações sobre como deveriam ser realizados os trabalhos de pesquisa com a criança e os grupos infantis. Bastide aponta os

\footnotetext{
${ }^{20}$ STAHL, P. J. A Respeito dos contos de fadas. IN: PERRAULT, Charles. Contos de Perrault. 2.ed. Belo Horizonte: Ed. Itatiaia, 1989. p. 15-47.

P. J. STAHL era o pseudônimo de Pierre Jules HETZEL (1814-1891) o famoso editor de Julio Verne. HETZEL foi o fundador de uma casa editorial que publicou Prodhon e Baudelaire e que fez a primorosa edição dos contos de Perrault ilustrada por Gustave Doré, fundou a Magasin d'Education et de Recreation, mas é muito conhecido pelas edições das Viagens Extraordinárias, de Julio Verne, de quem era grande amigo e incentivador.
} 
méritos do trabalho de Florestan, que com uma perspectiva etnográfica conseguiu fazer uma interpretação profunda dos grupos de crianças, que se reuniam nas ruas populares da cidade de São Paulo, na década de quarenta. Segundo Bastide:

“(...) há entre o mundo dos adultos e o das crianças como que um mar tenebroso, impedindo a comunicação. Que somos nós, para as crianças que brincam ao nosso redor, senão sombras? Elas nos cercam, chocam contra nós; respondem às nossas perguntas, num tom de condescendência, quando fingimos interessar-nos por suas atividades; mas sente-se, perfeitamente, que, para elas, somos como os móveis da casa, parte do cosmo exterior, não pertencemos a seu mundo, que tem seus prazeres e seus sofrimentos. E nós, os adultos, vivemos também dentro de nossas próprias fronteiras, olhamos as crianças brincar, repreendemo-las quando fazem muito barulho, ou se deixamos cair sobre seus divertimentos um olhar amigo, não é para eles que olhamos, mas, através deles, para as imagens nostálgicas de nossa infância desaparecida.

Para poder estudar a criança, é preciso tornar-se criança. Quero com isso dizer que não basta observar a criança, de fora, como também não basta prestar-se a seus brinquedos; é preciso penetrar, além do círculo mágico que dela nos separa, em suas preocupações, suas paixões, é preciso viver o brinquedo.(...)”21

Esse olhar antropológico também é importante para percebermos como a socialização, a transmissão e a mudança cultural ocorrem, dentro do universo infantil, mediadas pelas próprias crianças. O estudo clássico de Florestan Fernandes, As Trocinhas do Bom Retiro, já apontava em 1944, quando foi escrito, para a necessidade de se analisar o processo de socialização da criança dentro de seus próprios grupos. E com isso antecipava uma discussão que só aparecerá com força nas duas últimas décadas do século XX.

\footnotetext{
${ }^{21}$ BASTIDE, Roger. Prefácio, as Trocinhas do Bom Retiro. In: FERNANDES, Florestan. Folclore e mudança social na cidade de São Paulo. São Paulo: Martins Fontes, 2004. p.195.
} 
“(...) o interessante para nós, é que se trata exatamente, do aspecto da socialização elaborado no seio dos próprios grupos infantis, ou seja: educação da criança, entre as crianças e pelas crianças. A criança é modelada, é formada, também, através dos elementos da cultura infantil, pois estes elementos põem-na em contato direto com os valores da sociedade.”22

Como veremos, muitas das cartas de crianças mostram que o contato com os livros se dá por intermédio de outras crianças. Primos ou amigos emprestam livros, colegas de escola comentam as leituras, e os lançamentos de Lobato são vistos como objetos de desejo das crianças. É claro que não podemos esquecer que, em última análise, a mediação dos pais ou adultos da família era quase imprescindível, pois era necessário adquirir os exemplares. A esse respeito Peter Hunt, especialista em literatura infanto-juvenil, nos alerta para a mediação existente por parte dos adultos. São os pais que compram os livros para as crianças, no entanto a partir de certa idade as crianças passam a solicitar o livro desejado. Mas não podemos deixar de observar que a criança só pode escolher a partir do que está exposto. Assim existe uma mediação: editores, livreiros e bibliotecários fazem uma escolha antes dos pais e crianças.

Na correspondência estudada vemos quase que uma rede de leitores, o mesmo livro passa por todos os irmãos, primos ou mesmo vizinhos ${ }^{23}$.Neste caso é ainda interessante apontar para o fato que a correspondência praticamente não comenta o fato dos livros serem emprestados de bibliotecas públicas ou escolares, mesmo quando elas já existem. É muito mais freqüente a solicitação, a Lobato, de exemplares que ficariam disponíveis nas bibliotecas escolares.

Foi durante a década de 80 e 90, do século $X X$, que um grupo de cientistas sociais, descontentes com a forma como a infância era trabalhada principalmente pelo campo da psicologia, propuseram uma nova maneira de vê-la, estudando-a dentro do seu contexto histórico e social. Esse grupo

\footnotetext{
${ }^{22}$ FERNANDES, Florestan. As Trocinhas do Bom Retiro. In: Folclore e mudança social na cidade de São Paulo. 3.ed. São Paulo: Martins Fontes, 2004. p. 219.

${ }^{23}$ Clarice Lispector aborda esse universo da leitura por empréstimo em Felicidade Clandestina.
} 
denominado New Social Studies of Childhood, se constituiu por sociólogos, historiadores, psicólogos, antropólogos e geógrafos, que pretendiam abordar a infância como uma construção social, não levando em consideração sua natureza biológica. Uma das críticas recorrentes que esse grupo fazia aos estudos sobre a criança era a de que as crianças eram vistas como seres "ainda não sociais”, que não se prestava atenção na participação social que a criança tinha na sua vida coletiva. Autores como Allison James, Alan Prout, Chris Jenks e J. Hockey foram importantes no desenvolvimento dessa perspectiva.

Depois de mais de uma década desses estudos, inicia-se agora uma revisão empreendida por Alan Prout em seu livro The future of childhood. De forma geral, o autor analisa algumas premissas do grupo, e faz a crítica no sentido de ser necessário ver e estudar a infância não somente no plano histórico-social, mas de forma heterogênea se aproximando de campos até então evitados, como o da biologia. Nesse sentido, o autor constrói seu trabalho a partir do New Social Studies, mas reconsiderando criticamente algumas das suposições e posições do grupo. Em um dos pontos mais inovadores aborda a infância como fazendo parte simultaneamente de uma cultura e de uma natureza. Assim o cultural/social e o biológico não devem ser vistos como "entidades puras”, mas em inter-relação, de forma imbricada. Utiliza então a obra de Bruno Latour, We have never been modern, que coloca uma alternativa radical ao pensamento modernista, onde toda a relação entre o mundo da cultura e o da natureza foi abandonado, nada poderia mediá-los ou conectá-los. Latour vê a necessidade de repensarmos essa dualidade, vendo como cultura e natureza podem estar hibridizados. ${ }^{24}$

Prout recorre também a estudos feitos por primatologistas para entender a evolução da juvenilidade em várias espécies animais, especificamente em primatas. Apesar dos primatas não serem os únicos mamíferos com um extenso período juvenil, o enorme período de imaturidade é o traço mais importante nos padrões de história de vida entre os primatas e outros mamíferos. Assim como outras características que compartilhamos com os primatas como: cérebro complexo e grande, crescimento lento do corpo, reprodução adiada e vida longa. Dessa forma não podemos afirmar que

\footnotetext{
${ }^{24}$ LATOUR, B. Citador por: PROUT, Alan. The future of childhood. Towards the interdisciplinary study of children. New York; London: Routledge Falmer, 2005. p. 40-42.
} 
a infância é cultural e colocar de fora tudo o que é biológico, é necessário pensar além do dualismo natureza/cultura.

"Isso significa, por exemplo, compreender que uma juvenilidade extendida faz parte de nossa história como espécie e é algo que compartilhamos com outros primatas (...) Nessa perspectiva a infância não pode ser vista como um fenômeno biológico mas como a tradução dele na cultura. Todas as infâncias são, em parte, constituídas através de uma juvenilidade extensa e todas as culturas humanas tem de negociar com isto. Porque essa tradução na cultura pode ser feita de várias formas, as quais acrescentam e tiram traços através dos tempos, a infância aparece como um fenômeno muito diversificado.”25

A perspectiva aberta por Prout para a reflexão sobre a infância nos parece ser a mais apropriada, porque além de pensar a criança como um constructo histórico social, ela permite compreender também a importância que as questões biológicas têm sem ser, no entanto, determinista. Os autores que embasam seu trabalho permitem ver o mundo na sua complexidade e heterogeneidade, características importantes para entrar em um mundo como o das cartas enviadas pelas crianças.

Para entendermos esse mundo literário comentado pelas crianças nas cartas e nos artigos será necessário abordar, mesmo que de forma não muito aprofundada, um pouco do desenvolvimento da literatura infanto-juvenil. Como ela se transformou e como podemos ver no Brasil uma diferença entre a produção de Lobato e a dos autores que o precederam, é o que se fará a seguir.

\footnotetext{
${ }^{25}$ PROUT, Alan. The future of childhood. Towards the interdisciplinary study of children. New York; London: Routledge Falmer, 2005. p. 111. (minha tradução)
} 


\title{
Livros para a infância
}

\author{
“Criança da pura fronte sem névoas \\ E sonhadores olhos de espanto! \\ Embora o tempo seja veloz \\ E meia vida separa você e eu \\ Seu adorável sorriso bem certo saudará \\ O presente de amor de um conto de fadas” \\ Lewis Carrol \\ Alice através do espelho
}

A literatura voltada às crianças se desenvolveu e se consolidou definitivamente durante o século XIX. No entanto, diversos pesquisadores acreditam que ela é herdeira das canções de gesta, lais medievais que foram sendo transmitidos oralmente e que incorporaram narrativas primordiais que remontam à difusão da cultura indo-européia, tendo se transformado no decorrer dos séculos. Todo esse universo da cultura popular era transmitido de forma oral e no decorrer dos séculos XVI e XVII começaram a ser registrados de modo escrito, por eruditos que começavam a se preocupar com a formação de uma cultura baseada em material autóctone, que serviria posteriormente para se pensar em uma identidade nacional. Dentre estes, Charles Perrault (1628-1703) é sempre apontado como um precursor, apesar de estar inserido em um contexto de criação para o público adulto. Seu livro mais conhecido, Histórias ou contos do tempo passado, com suas moralidades. Contos de minha Mãe Gansa (1697) reunia oito histórias retiradas da tradição popular. Mais recentemente, na ótica da história cultural, sua obra tem sido analisada no contexto da Querela dos Antigos e dos Modernos, que se desenvolveu na Academia Francesa, da qual Perrault fazia parte. Um de seus opositores nessa disputa era também um autor que produziu uma obra importante que posteriormente seria divulgada para a infância, as Fábulas, de Jean La Fontaine (1621-1692). Joan DeJean em seu livro, Antigos contra Modernos, analisa a disputa entre esses intelectuais, que de uma parte defendiam a escrita literária em versos (La Fontaine), modelo francês do século XVII, e de outra pretendiam transformar a escrita, 
introduzindo gêneros literários como o romance e o conto (Perrault). A autora também mostra em seu trabalho como as mulheres tiveram um papel muito importante na criação literária da época, escrevendo e recriando contos de origem popular. ${ }^{26}$

No entanto, cabe ressaltar que esses autores não produziram tais obras especificamente para um público infantil, as crianças só terão essas obras publicadas especialmente para elas no decorrer do século XIX, quando esses textos receberam edições ilustradas e voltadas para a infância e, em muitos casos, com textos modificados. Podemos analisar esse crescimento das publicações voltadas para um público infanto-juvenil em certa medida como parte do processo de alfabetização compulsória pelo qual passavam as nações européias durante esse período engendrado, sobretudo, pelo nacionalismo, de fins do século XIX. O trabalho clássico de Eric J. Hobsbawm, A Era dos Impérios, nos mostra como nesse período a criação do nacionalismo étnicolinguístico foi também a "grande era da alfabetização em massa". ${ }^{27} \mathrm{Na}$ última década do século XIX, a Europa ocidental possuía cerca de 90\% de sua população alfabetizada e as obras para crianças, que no início do século eram principalmente de cunho moral e didático, passaram a contar com elementos de exotismo, fantasia e magia. Mas devemos também lembrar que toda uma indústria voltada para artigos específicos da infância começava a surgir ainda no século XVII, como as oficinas de brinquedos e miniaturas, que se desenvolveram nas cidades alemãs, como Nuremberg, Munique e Sonneberg, entre outras. Às miniaturas e brinquedos que começam a ser fabricados nesse período se somam os livros de gravuras, ou os volumes de pequeno tamanho, que tinham uma estante específica para serem guardados $^{28}$.

Durante o século XIX obras clássicas como as Fábulas de La Fontaine e Contos de Perrault foram editadas com belíssimas ilustrações de Gustave Doré, em volumes primorosos pela casa editorial de Hetzel. Esses volumes tinham um preço alto e estavam destinados às classes mais

\footnotetext{
${ }^{26}$ DEJEAN, Joan. Antigos contra Modernos.As guerras culturais e a construção de um fin de siècle. Rio de Janeiro: Civilização Brasileira, 2005.

${ }^{27}$ HOBSBAWM, Eric. J. A Era dos Impérios. 1875-1914. 8 ed. Rio de Janeiro: Paz e Terra, 2003. p 222.

${ }^{28}$ BENJAMIN, Walter. "Velhos Brinquedos” e "História Cultural do Brinquedo” In: Reflexões sobre a criança, o brinquedo e a educação. São Paulo: Duas Cidades; Ed. 34, 2002. p. 81-94.
} 
abastadas, no entanto as histórias de fadas também circulavam nas brochuras baratas da Bibliothequè Bleue, sendo consumidas por crianças e adultos de todas as classes sociais.

Refletindo sobre os livros infantis publicados durante os séculos XVIII e XIX, Walter Benjamin faz um paralelo entre o fascínio que a criança tinha frente os resíduos que se originavam da construção, do trabalho de costureiras e outras atividades, e a apropriação que faziam dos contos do universo popular:

“(...) Com isso as crianças formam o seu próprio mundo de coisas, um pequeno mundo inserido no grande. Um tal produto de resíduos é o conto maravilhoso, talvez o mais poderoso que se encontra na história espiritual da humanidade: resíduos do processo de constituição e decadência da saga. A criança consegue lidar com os conteúdos do conto maravilhoso de maneira tão soberana e descontraída como o faz com retalhos de tecidos e material de construção. Ela constrói o seu mundo com os motivos do conto maravilhoso, ou pelo menos estabelece vínculos entre os elementos do seu mundo. (...),29

Walter Benjamin nos mostra que apesar dos contos de fadas, ou maravilhosos, não terem sido produzidos, com o objetivo único de se destinarem as crianças, elas se relacionam com eles de maneira "soberana e descontraída" assim como fazem com retalhos e materiais residuais da atividade adulta. As crianças estabelecem assim com os contos e fábulas uma nova relação, construindo um mundo peculiar e autônomo a partir de seus motivos.

Durante o século XVIII surge também uma literatura que no século seguinte chega ao público infantil transformada: são os primeiros romances modernos envolvendo uma forma de narrativa que, atrelada à realidade nascente, vai se tornar um sucesso absoluto de público. As duas narrativas que se destacam são Robinson Crusoé, de Daniel Defoe (1660-1731) publicado em 1719, e traduzido para o português em 1786 e Viagens de Gulliver, de

\footnotetext{
${ }^{29}$ BENJAMIN, Walter. Livros infantis velhos e esquecidos. In: Reflexões sobre a criança, o brinquedo e a Educação. São Paulo: Duas Cidades; Ed. 34, 2002. p. 58
} 
Jonathan Swift (1667-1745) publicado em 1726, e traduzido para o português em 1822. O próprio Lobato fará sua obra infantil norteado pela lembrança que a leitura de Robinson deixara em sua memória. Em sua correspondência com Rangel, Lobato comenta o desejo de criar obras infantis onde as crianças possam “morar”, como ele próprio havia “morado” no Robinson Crusoé, de Daniel Defoe, Nos filhos do Capitão Grant, de Julio Verne e no Rocambole, de Ponson du Terrail.

Michel de Certeau chega a considerar Robinson Crusoé uma narrativa mítica, "um dos raros mitos que a sociedade ocidental moderna foi capaz de inventar”. Sua importância, para ele, se deve ao fato da obra falar da própria escrita, da transformação do mundo natural e da produção de um sistema de objetos por um sujeito. $^{30}$ Já o crítico Otto Maria Carpeaux considerava Robinson "um livro de conseguir sucesso", isto é, de “como estabelecer uma sucursal numa ilha deserta”. “A obra pode ser interpretada como manual do escoteiro na solidão selvagem - mas também como história da sociedade burguesa, que é uma sociedade de indivíduos isolados, lutando cada um por sua ventura.” - escreveu ele. ${ }^{31}$ Nessa mesma perspectiva Ian Watt aborda Robinson Crusoé como um dos mitos do individualismo moderno, juntamente com D. Quixote, D. Juan e Fausto. Watt analisa o individualismo econômico e também o religioso, presentes na obra, elucidando alguns dos significados do que é considerado por ele um dos principais e mais populares mitos da modernidade. ${ }^{32}$

No entanto, essas obras sofrerão, assim como as de Perrault e La Fontaine, várias adaptações que muitas vezes esvaziaram as análises e críticas empreendidas pelos autores, retirando-as do seu contexto original como no caso da obra de Swift. Tendo sido subtraída a crítica social o que restava das obras nessas versões para crianças era o exótico, a aventura, a ação e o heroísmo dos protagonistas. A transposição de Robinson ou de Gulliver para o universo da literatura infantil se fará, na maior parte das

\footnotetext{
${ }^{30}$ CERTEAU, Michel. A invenção do cotidiano. Artes do fazer. 2.ed. Petrópolis: Vozes, 1996. p. 227.

${ }^{31}$ CARPEAUX, Otto Maria. História da Literatura Ocidental. 2.ed. Rio de Janeiro: Ed. Alhambra, 1984. vol 4. p.870-871.

${ }^{32}$ WATT, Ian P. Mitos do Individualismo Moderno: Fausto, Dom Quixote, Dom Juan, Robinson Crusoé. Rio de Janeiro: Jorge Zahar, 1997.

WATT, Ian P. A ascensão do romance: Defoe, Richardson e Fielding. 3.ed. São Paulo: Companhia das Letras, 1990.
} 
vezes, através de uma simplificação da história original, além de uma unificação e redução na linguagem e da utilização de ilustrações sugestivas. Além disso, podemos perceber que cada adaptador/tradutor tem uma concepção própria de infância e também de um modelo educacional a ser divulgado, como mostra Gabriela Pellegrino Soares, em seu livro: Semear Horizontes, quando faz uma interessante comparação entre as traduções e adaptações de Viagens de Gulliver, no Brasil e na Argentina ${ }^{33}$. Sendo assim, em cada adaptação/tradução temos a mediação feita por um adulto, com um determinado propósito que modificará estruturalmente a leitura feita pelas crianças.

O sucesso que essas obras fizeram nesse universo infanto-juvenil, do qual não eram originárias, pode ser analisado pela capacidade que tinham em sugerir às crianças a autonomia, que tanto desejavam, em uma sociedade fortemente patriarcal, onde cabia a criança somente obedecer. A fuga para uma região exótica, as peripécias dos protagonistas e sua autonomia frente ao mundo, deveriam parecer às crianças do século XIX um mundo idílico, encontrado posteriormente por elas também em alguns outros autores como em Júlio Verne.

Dessa forma foi durante o século XIX que se desenvolveu uma rica literatura voltada exclusivamente para a criança e o jovem. Logo nas primeiras décadas desse século temos a publicação da obra de Jacob (17851863) e Wilhem (1786-1859) Grimm, Contos de fadas para Crianças $e$ Adultos, publicada entre os anos 1812-1822. Esses contos da narrativa popular foram coletados pelos irmãos Grimm, mas sofreram posteriormente modificações para que pudessem se destinar às crianças. De fato, os contos coletados pelos irmãos Grimm já eram resultantes de uma cultura popular que os havia recebido por meio de variantes escritas. Uma das informantes dos Grimm, Jeannette Hassenpflug os havia ouvido da mãe, que descendia de uma família francesa huguenote, que por sua vez, provavelmente havia tido contato com os contos de fadas publicados no século XVII. A esse respeito Robert Darnton comenta:

\footnotetext{
${ }^{33}$ SOARES, Gabriela Pellegrino. Semear Horizontes. Belo Horizonte: Ed. UFMG, 2007. p. 375-387.
} 
“(...)Assim, ‘Chapeuzinho Vermelho’ inseriu-se na tradição literária alemã e, mais tarde, na inglesa, com suas origens francesas não detectadas. Ela mudou consideravelmente suas características, ao passar da classe camponesa francesa para o quarto do filho de Perrault e daí partir para a publicação, atravessando depois o Reno e voltando para uma tradição oral, mas, desta vez, como parte da diáspora huguenote, dentro da qual retornou sob a forma de livro mas, agora, como produto da floresta teutônica, em lugar das lareiras das aldeias do tempo do Antigo Regime, na França.”34

Nessa passagem, Robert Darnton nos elucida o percurso que muitas das histórias da cultura popular tradicional européia tiveram, migrando da forma oral para a escrita, para retornarem novamente à forma oral e daí para o livro dos irmãos Grimm. Esse movimento mostra como o mundo da palavra escrita e da oralidade está imbricado um no outro durante o século XIX. Sendo assim, devemos lembrar que é importante reconhecer as permanências da oralidade no mundo dos impressos, sem esquecer contudo que as histórias também passam do papel para o verbal.

Outro autor importante do mesmo século, no que concerne a obra dedicada às crianças, foi o escritor dinamarquês Hans Christian Andersen (1805-1875). A produção desse autor se diferenciava das anteriores, embora também fosse herdeira da literatura popular oral, pela criação de histórias onde alguns aspectos românticos estarão presentes. Nelly Novaes Coelho considera que Andersen foi “(...) a primeira voz autenticamente romântica a contar histórias para as crianças e a sugerir-lhe padrões de comportamento a serem adotados pela nova sociedade que se organizava”35 De fato, grande parte das histórias criadas por Andersen tocavam em questões caras aos românticos, como a individualidade dos protagonistas, que para realizarem seus sonhos e desejos muitas vezes têm de passar por inúmeras provações e sofrimentos para que, a partir, dessa trajetória possam encontrar a purificação

\footnotetext{
${ }^{34}$ DARNTON, Robert. Histórias que os camponeses contam: o significado de Mamãe Ganso. In: $o$ Grande massacre de gatos e outros episódios da história cultural francesa. 4 ed. Rio de Janeiro: Graal, 2001. p.24-25

${ }^{35}$ COELHO, Nelly Novaes. Panorama Histórico da Literatura Infantil/Juvenil. 3 ed. São Paulo: Quiron, 1985. p.119.
} 
e a elevação espiritual. Muitas das histórias não têm o final feliz adocicado que o século XX vai se empenhar em mostrar às crianças, sobretudo, a partir das adaptações feitas para o cinema por Disney. Pelo contrário, as histórias muitas vezes têm finais trágicos com conteúdos morais muito nítidos.

Muitos outros autores surgem durante o século XIX e consolidam uma literatura voltada para jovens e adultos, dentre esses nomes podemos citar o de Walter Scott (1771-1832), escritor escocês que desenvolveu romances históricos como Ivanhoé, publicado em 1820. No campo de histórias de suspense e aventuras temos vários autores todos bastante traduzidos e lidos no Brasil, desde meados do século XIX, como Eugene Sue (1804-1857) cuja obra mais conhecida Mistérios de Paris, foi publicada em 1842, por meio de folhetins, tendo alcançado um público enorme ${ }^{36}$. Outro autor muito lido do período foi Maurice Leblanc (1864-1941), criador do personagem Arséne Lupin, um ladrão de casaca que desafiava os detetives da belle-époque, em alguns livros o personagem se defrontava com Herlock Sholmes criando situações muito embaraçosas para o detetive inglês parodiado. Um dos mais lidos desses autores franceses no Brasil parece ter sido Ponson du Terrail (1829-1871) criador de Rocambole, romance que será publicado primeiramente em folhetins e posteriormente teve sua obra reunida em uma série de volumes, sempre relembrado por muitos escritores do período. Também Alfonse Daudet (1840-1897), autor de Tartarin de Tarascon, teve muito sucesso no Brasil, sendo citado inúmeras vezes pelo próprio Monteiro Lobato, principalmente quando relembrava sua juventude passada na república do Minarete.

No entanto, o mais lido de todos os autores que se dedicaram a esse gênero era Júlio Verne (1828-1905), cujas obras publicadas primeiramente em capítulos em algumas revistas como na Le Magasin d'Education et de Recreátion eram devoradas pelos leitores e ganharam muitas edições em várias línguas. Tendo sido muito lido nas últimas décadas do século XIX no Brasil, podemos observar comentários sobre a leitura de suas obras na infância em muitas memórias e biografias. Olavo Bilac escreve, por ocasião

\footnotetext{
${ }^{36}$ A seção de manuscritos da Biblioteca Nacional do R. J. possui um parecer de André Pereira Lima, encarregado de autorizar textos adaptados para o teatro, que data de 1844, nesse documento o parecerista reconhece o enorme sucesso que "Os Mistérios de Paris” havia alcançado em nosso país, no entanto, diz ser a adaptação teatral infiel ao romance.
} 
da morte de Júlio Verne, um artigo onde faz uma reflexão sobre a importância da leitura de seus romances de aventura durante a sua puberdade. Inicia sua crônica com a descrição de uma cena na Biblioteca Nacional: um “mocinho imberbe” lê com voracidade um volume. Bilac narra cada um dos movimentos que o leitor faz: agitação febril dos olhos, rugas na testa, corpo tenso, que só relaxa ao ler a última linha. Quando o rapaz se levanta e vai embora, ele curioso vai até a mesa para ver que livro o jovem havia lido. Era a obra Da Terra à Lua, de Júlio Verne. Identificando-se com o leitor, Olavo Bilac tece comentários sobre a saudade que sente das leituras realizadas na sua puberdade:

“Oh! a saudade, a deliciosa e dolorosa saudade que me apertou o coração! saudade dos meus treze anos, da minha inquieta e sofredora puberdade, agitada de sonhos que ninguém compreendia, de distrações que ninguém perdoava, de súbitos acessos de fervor de estudo e de preguiça, e das vagas torturas de uma imaginação que acordava e não se entendia a si mesma...”

Logo em seguida discorre sobre o que a leitura das obras de Júlio Verne significava para ele e para os de sua geração:

“Graças, porém, a Júlio Verne, eu fugia, num surto vitorioso, deste mundo que me aborrecia, e entrava, cantando, vestido de luz, sorrindo, delirando, nos mundos radiantes que a sua piedade abria à minha imaginação”.(...)

“(...) O que mais desenvolveu a minha imaginação e o que consolou as vagas e indefiníveis tristezas da minha adolescência foi a leitura de Júlio Verne. Todos os homens da minha idade dirão o mesmo.”37

Já Lobato, por sua vez, via a leitura de Julio Verne não como fuga da realidade, mas como motor de descobertas:

"Recordando minha vida colegial vejo quão pouco os mestres contribuíram para a formação do meu espírito. No entanto, a Julio Verne todo um mundo de coisas eu devo.(...)

\footnotetext{
${ }^{37}$ BILAC, Olavo. Julio Verne, o bonde, o burro e outros escritos. São Paulo: Ed. Barcarolla, 2004. p19 e 22.
} 
Julio Verne levou-me a Humboldt, e depois a geografia e as demais ciências físicas e sociais. Foi o aperitivo. Entreabriu-me as cortinas do mundo como coisa viva e pitoresca, composta de paisagens e dramas(...),38

Essas duas posturas sobre a leitura podem também ser percebidas nas cartas dirigidas a Lobato por seus leitores. Como veremos a frente, alguns leitores afirmam ser a leitura um momento de evasão, enquanto lêem se transportam para o mundo imaginário que se desenrola e assim passam agradáveis horas de leitura. Quando retornam desse mundo idílico trazem essa sensação de tranquilidade por passarem algum tempo longe de um cotidiano maçante ou de uma realidade difícil. Outros leitores, porém, apesar de também afirmarem que "vivem” no Sítio, que se transportam para dentro da obra, parecem retornar dessa viagem com algo a mais, uma curiosidade sobre algum autor mencionado, uma vontade de transformar a realidade. A leitura para esses últimos é mais que simples entretenimento e fuga, é também um impulso que os leva para dentro do cotidiano. Não necessariamente são as obras mais sérias e didáticas que fazem com que o leitor desenvolva esse sentimento de pertencer ao mundo, esse desejo de saber mais e transformar a realidade, nos capítulos seguintes discutiremos de forma mais aprofundada essas formas de se realizar a leitura.

Essa postura ligada ao prazer que certas obras suscitavam nos leitores está relacionada também ao teor imaginativo da narração, assim é necessário também citar outros autores do mesmo período que se dedicaram a construir obras onde um universo mais onírico, fantástico ou mesmo ligado ao nonsense estavam presentes. Esses autores criaram suas obras, principalmente, para crianças mais novas que ainda não liam obras como as de Júlio Verne ou Ponson du Terrail. No entanto não faltavam aventuras e situações inusitadas em seus livros que foram imensamente vendidos, entre os mais importantes do período estão: Lewis Carrol (1832-1898) criador de Alice no País das Maravilhas, dentre outras obras; Collodi (1826-1890) com a obra Pinnochio, lançada como folhetim no Giornale dei Bambini; James M. Barrie (18601937) que concebeu Peter Pan, primeiramente como uma peça teatral e depois

\footnotetext{
${ }^{38}$ MONTEIRO LOBATO. Mundo da Lua e miscelanea. São Paulo: Brasiliense, 1957. Obras Completas. vol.10. p. 8-9.
} 
como livro, Peter Pan e Wendy, publicado em 1911 e Beatrix Potter (18661943) criadora do personagem Peter Rabbit, e de livros em pequeno formato repletos de ilustrações.

Grande parte desta literatura foi traduzida e adaptada por Monteiro Lobato e, em alguns casos, dentro dos livros nos quais aparecia a turma do Sítio do Picapau Amarelo, como foi o caso de Peter Pan, transformado em amigo de Narizinho e Pedrinho, ou ainda como Pinnochio lido e comentado por Dona Benta. Em outros casos as obras apareciam traduzidas por Lobato na coleção Terramarear, como é o caso de Rudyard Kipling (1865-1936) e Edgard Rice Burroughs (1875-1950). Lobato vai também traduzir e adaptar obras que mais tarde reunirá na coleção das obras completas: os Contos de Andersen, de Grimm, de Perrault, Alice no País das Maravilhas, Através do Espelho e Robinson Crusoé. Assim como também será o responsável pela tradução de importantes obras da coleção Terramarear e da Paratodos da Cia. Editora Nacional. José Paulo Paes refere-se à importância dessas coleções:

“Não sei se se deve a Monteiro Lobato a idéia de lançá-las, mas sei que foi ele quem traduziu alguns de seus melhores títulos. De resto, além da importância dos autores publicados, escolhidos a dedo, ambas as coleções primavam pela qualidade de suas traduções, feitas por escritores como Manuel Bandeira, Godofredo Rangel, Agripino Grieco e outros. Quando falo na importância dos autores selecionados para a Terramarear e Paratodos, não me refiro apenas àqueles que têm seus nomes incluídos na história literária, a exemplo de Herman Melville, Rudyard Kipling, R. L. Stevenson ou Jack London. Refiro antes e sobretudo a autores como Mayne Reid, Emilio Salgari, Edgar Rice Burroughs, Rafael Sabatini etc., autores menosprezados pela crítica sob a alegação de serem 'comerciais', mas que pela sua competência e dedicação a uma modalidade de literatura tida por 'menor', aliciaram milhões de leitores, ensinandolhes desde cedo o prazer da leitura e preparando-os para a ulterior fruição de obras literárias de maior complexidade de fatura e de maior ambição de propósitos.”39

\footnotetext{
${ }^{39}$ PAES, José Paulo. A aventura literária. Ensaios sobre ficção e ficções. São Paulo: Companhia das Letras, 1990. p. 16.
} 
Dessa forma grande parte da literatura produzida para crianças e jovens no século XIX e décadas iniciais do século XX estará disponível, a partir das décadas de 30 e 40, em traduções bem feitas por escritores nacionais. Essas obras que podem ser classificadas de "romances de aventuras” ${ }^{40}$ tiveram inúmeras edições e circularam enormemente durante o período estudado. A documentação pesquisada mostra que as crianças e jovens comentavam as traduções feitas por Lobato, e também por outros autores, tanto que na correspondência enviada a Lobato as crianças chegavam a sugerir traduções ao autor. Assim percebemos que durante o período estudado já existia um mercado bastante complexo e completo no que diz respeito às traduções de obras estrangeiras, diferentemente do que acontecia no início do século XX.

Monteiro Lobato repetidas vezes afirmava que criara sua obra infantil como forma de suprir uma lacuna, pois seus próprios filhos não tinham o que ler. As traduções portuguesas eram enfadonhas e carregavam um linguajar lusitano que por vezes impossibilitava a compreensão do texto por crianças brasileiras. Edgard Cavalheiro citando Afonso Schmidt dá a dimensão dessa situação:

“De noite, na mesa de jantar, à luz do lampião belga que pendia do teto, eram freqüentes estas conversas:

- Papai, que quer dizer palmatória?

- Palmatória é um instrumento de madeira com que antigamente, os mestres-escola davam 'bolos' nas mãos das crianças vadias...

O pai botava os óculos, lia o trecho, depois explicava:

- Pelo assunto, neste caso, deve ser - castiçal. Parecido, não? Como um ovo com um espeto!

Minutos depois, a criança interrompia novamente a leitura.

- Papai, que é caçoula?

- Caçoula, que eu saiba, é uma vasilha de cobre, de prata ou de ouro, onde se queima incenso.

- Veja aqui na história. Não deve ser isso...

\footnotetext{
${ }^{40}$ Essa denominação é utilizada por José Paulo Paes no ensaio “As dimensões da aventura” em $A$ Aventura Literária. Ensaios entre ficção e ficções. São Paulo: Companhia das Letras, 1990. p.11 a 24.
} 
O pai botava os óculos de novo e lia, em voz alta: 'O bicho de cozinha deitou água fervente na caçoula atestada de beldroegas, e asinha partiu na treita dos três mariolas...'

Depois de matutar sobre o caso, o pai tentava o esclarecimento:

- Caçoula deve ser panela... Parecido, não?

E a mãe, interrompendo o crochê:

- Afinal, por que não traduzem esses livros portugueses para as crianças brasileiras?” 41

Ainda sobre as obras para crianças editadas em Portugal incompreensíveis às crianças brasileiras, temos o testemunho de outro memorialista, Luis Edmundo que reproduz um trecho em seu livro O Rio de Janeiro do meu tempo:

"E o petiz que andava às cavalitas do avô vendo o marçano que trazia o cabaz pleno de molhos de feijões verdes, sai-se-lhe com esta: a mamã que t’o conte"42

Os livros infantis vindos de Portugal eram inacessíveis aos leitores brasileiros, pois inúmeros vocábulos eram totalmente desconhecidos deste lado do Atlântico. Daí o comentário da mãe, da necessidade de se traduzir os livros portugueses. Percebemos que a circulação de livros vindos de Portugal deveria ser expressiva também pela menção de Graciliano Ramos em Infância. O autor não menciona a dificuldade de compreensão da linguagem, mas nos relata um outro problema:

“Apareceu uma dificuldade, insolúvel durante meses. Como adquirir livros? No fim da história do lenhador, dos fugitivos e dos lobos havia um pequeno catálogo. Cinco, seis tostões o volume. Tencionei comprar alguns, mas José Batista me afirmou que aquilo era preço de Lisboa, em moeda forte. E Lisboa ficava longe.”43

\footnotetext{
${ }^{41}$ CAVALHEIRO, Edgard. Monteiro Lobato. Vida e obra. 3 ed. São Paulo: Brasiliense, 1962. vol. II p.145-146.

${ }^{42}$ EDMUNDO, Luiz. O Rio de Janeiro do meu tempo. Rio de Janeiro: Imprensa Nacional, 1938. p. 734. Citado em EL FAR, Alessandra. Páginas de Sensação. Leitura popular e pornográfica no Rio de Janeiro (1870-1940). São Paulo: Cia das Letras, 2004. p. 93.

${ }^{43}$ RAMOS, Graciliano. Infância. 37. ed. Rio de Janeiro: Record, 2003. p. 229.
} 
O menino Graciliano, mesmo morando em uma pequena cidade do sertão de Pernambuco, entra em contato com um livro editado em Portugal. Entretanto, a aquisição de outros exemplares, lusitanos ou brasileiros, para ele era um obstáculo intransponível. Nos primeiros anos do século XX, período da infância de Graciliano, essa dificuldade deveria ser freqüente para os leitores que residiam no interior, longe das maiores capitais. Percebemos, assim, que apesar de existirem exemplares vindos de Portugal, poucos deveriam ser os leitores que tinham acesso a eles, devido sobretudo a circulação rarefeita de exemplares fora dos principais centros urbanos.

Os principais biógrafos de Monteiro Lobato, assim como grande parte da bibliografia sobre a história da literatura infantil em nosso país, indicam que Lobato pode ser considerado um pioneiro, muitos chegam a dizer que nada ou muito pouco existia antes da publicação de Narizinho Arrebitado. Podemos ver claramente essa postura em Edgard Cavalheiro:

“A literatura infantil praticamente não existia entre nós. Antes de Monteiro Lobato havia tão somente o conto com fundo folclórico. Nossos escritores extraíam dos vetustos fabulários o tema e a moralidade das engenhosas narrativas que deslumbraram e enterneceram as crianças das antigas gerações, desprezando, frequentemente, as lendas e tradições aparecidas aqui, para apanharem nas tradições européias o assunto de suas historietas.”44 Como vemos, Cavalheiro desconsidera a produção realizada anteriormente a Lobato por não considerá-la genuinamente brasileira. Essa discussão sobre a criação de uma literatura verdadeiramente brasileira pode ser vista desde os tempos de nossa independência política, e foi argutamente analisada por Roberto Schwarz, em Nacional por Subtração ${ }^{45}$. Para Schwarz grande parte da discussão intelectual passava pela necessidade de estabelecer uma produção cultural sem o caráter postiço e de imitação. Apesar disso, os homens de cultura que pensavam um projeto voltado à infância não podiam desconsiderar a produção mundial, assim era importante traduzir os clássicos como Perrault, Andersen, Irmãos Grimm e

\footnotetext{
${ }^{44}$ CAVALHEIRO, Edgard. Monteiro Lobato. Vida e obra. 3.ed. São Paulo: Brasiliense, 1962. p. 144. ${ }^{45}$ SCHWARZ, Roberto. Nacional por Subtração. In: Que horas são? Ensaios. São Paulo: Companhia das letras, 1997.
} 
outros marcos da literatura mundial, como Robinson Crusoé, Dom Quixote e mesmo As 1001 Noites. No entanto, esses clássicos deveriam estar vestidos com a língua nacional, sem os lusitanismos, e de preferência estarem ambientados em uma natureza mais próxima da nossa.

Apesar de este projeto ser bem anterior às obras de Lobato a bibliografia sobre literatura infantil, por exemplo, menciona pouco o trabalho como o de Carlos Jansen que traduziu de 1882 a 1901, para a Editora Laemmert, as grandes obras como As 1001 Noites, que teve prefácio de Machado de Assis, Robinson Crusoé, As Aventuras Pasmosas do celebérrimo Barão de Münchhausen e Dom Quixote. Como veremos desde as duas últimas décadas do século XIX teremos autores preocupados em traduzir e também em produzir obras destinadas exclusivamente às crianças, essas obras tanto eram utilizadas em escolas, como as de Júlia Lopes de Almeida, Coelho Neto e Olavo Bilac, como também estavam mais circunscritas a um âmbito doméstico.

Foi nesse contexto que um livreiro estabelecido na capital da República, Pedro da Silva Quaresma, publicou uma série de volumes a partir de 1894. O primeiro, de uma série, intitulado: Histórias da Carochinha foi escrito por Figueiredo Pimentel ${ }^{46}$, escritor que havia um ano antes publicado pela mesma livraria um livro polêmico que alcançou um número elevado de vendas: O Aborto livro considerado "leitura para homens". Ao se refletir sobre o número de edições que Histórias da Carochinha ${ }^{47}$ teve, parece que o público leitor carioca não se importava com o fato do mesmo escritor ser também o autor de obras pouco recomendáveis. Figueiredo Pimentel além de escrever mais três obras controversas como: Suicida! (1895), Um canalha (1895), O terror dos maridos - scenas da alta sociedade (1896), era o responsável pela chamada Biblioteca Infantil, tendo publicado depois de Histórias da Carochinha as seguintes obras: Histórias do Arco da Velha, Histórias da Avozinha, Histórias da Baratinha, Os meus brinquedos, Teatro infantil e O álbum das crianças.

\footnotetext{
${ }^{46}$ Figueiredo Pimentel publicou livros de enorme vendagem para a época, e anos depois se tornou o cronista responsável pela coluna “O Binóculo”, na Gazeta de Notícias. Nessa coluna foi o autor da frase: “O Rio Civiliza-se” pronunciada por ocasião da Reforma Pereira Passos.

${ }^{47}$ Em catálogo de 1901, a livraria do povo de Pedro Quaresma informava que Histórias da Carochinha estavam em $18^{\mathrm{a}}$ edição, tendo em vista a data da $1^{\mathrm{a}}$ edição, totalizava mais de duas edições por ano.
} 
É interessante notar como a obra Histórias da Carochinha é citada por Lobato em Reinações de Narizinho. A cena do encontro se dá quando a menina está visitando o Reino das Águas Claras. Dona Carochinha aparece procurando Pequeno Polegar, que havia fugido de seu livro e, assim, explica o sumiço do personagem:

“- Porque ele fugiu? - indagou a menina.

- Não sei - respondeu Dona Carochinha, mas tenho notado que muitos dos personagens das minhas histórias já andam muito aborrecidos de viverem toda a vida presos dentro delas. Querem novidade. Falam em correr o mundo a fim de se meterem em novas aventuras. Aladino queixa-se de que sua lâmpada maravilhosa está enferrujando. A Bela Adormecida tem vontade de espetar o dedo noutra roca para dormir outros cem anos.(...) Andam todos revoltados, dando-me um trabalhão para conte-los. Mas o pior é que ameaçam fugir, e o Pequeno Polegar já deu o exemplo.(...)

- Tudo isso - continuou Dona Carochinha - por causa do Pinocchio, do Gato Félix e sobretudo de uma tal menina do narizinho arrebitado que todos desejam muito conhecer.(...)”

Nesse trecho podemos perceber em certa medida a opinião que Lobato tinha a respeito dos Contos da Carochinha, já que a própria Narizinho na seqüência do diálogo chama esses livros de "bolorentos”. Personagens tão diversos como o Gato Félix, Pinóquio, assim como de Narizinho, atraem a curiosidade de Branca de Neve, Pequeno Polegar e outros. Como se os velhos personagens, cansados de suas histórias, pudessem sair dos livros para viverem novas aventuras. Essa idéia, que aparece pela primeira vez em Reinações de Narizinho, será o mote para o desenvolvimento da obra: $O$ Picapau Amarelo, onde os personagens dos contos da carochinha, além de outros como D. Quixote, se mudam para o sítio de D. Benta.

Dessa forma, já nos primeiros livros publicados por Lobato, assim como em muitos outros momentos de sua obra voltada para a infância, vemos que o autor se utilizava de recursos modernistas, como o uso da metalinguagem. Lobato utilizava-se de personagens exteriores a sua obra, vindos tanto das histórias de fadas ou da cultura popular, como de personagens ligados aos novos meios de comunicação como o cinema, o 
rádio e os quadrinhos e fazia com que seus personagens dialogassem com todos esses elementos, produzindo uma obra dinâmica e atual para o período. Além disso, possibilitava por meio de sua escrita que as crianças percebessem nitidamente a presença do autor e suas opiniões, nos textos lidos. Como veremos, essa forma peculiar de escrever para crianças deve ser levada em consideração ao analisarmos a documentação, pois provavelmente as escolhas que Lobato fez ao construir suas narrativas moldaram a recepção de sua obra, como podemos ver nas cartas escritas pelas crianças.

Mas, durante a última década do século XIX, não eram somente os livros de Figueiredo Pimentel que apareciam em um mercado que dava seus primeiros passos. Teremos ainda nesse período uma produção voltada para o público infantil realizada por figuras importantes daquele momento literário, como Júlia Lopes de Almeida, Coelho Netto, Olavo Bilac, Manoel Bonfim, João Kopke, Viriato Correa, e outros que, apesar de terem tido destaque e algum sucesso de vendas na época, não são tão lembrados como: Zalina Rolim, Francisca Júlia, Alexina de Magalhães Pinto, Presciliana Duarte de Almeida $^{48}$. Toda essa literatura era utilizada nas escolas, e tinha como orientação um compromisso com a retidão moral, com a religião cristã, a valorização da pátria e, em muitos casos, o desenvolvimento do apego aos estudos e à leitura.

Nesse momento parece que ainda não temos uma diferenciação muito estabelecida entre a literatura escolar e a não-escolar. Ambas se caracterizam por uma visão de infância muito peculiar, já que as obras são quase que em sua totalidade baseadas na premissa que a criança deve ser educada, que seus ímpetos devem ser contidos. Muitos dos contos e poesias são calcados também na moral cristã, a compaixão pelo sofrimento dos órfãos e o cuidado com idosos, são alguns temas que aparecem com freqüência. Muitos livros têm sua primeira edição somente como um livro de contos ou de poesias voltados à infância, para em segundas edições serem recomendados como livros de leitura para algumas séries específicas do

\footnotetext{
${ }^{48}$ Sobre as mulheres leitoras e escritoras ver: ELEUTÉRIO, Maria de Lourdes. Vidas de Romance. As mulheres e o exercício de ler e escrever no entresséculos. 1890-1930. Rio de Janeiro: Topbooks, 2005.
} 
ensino primário. Provavelmente os autores escreviam um livro já pensando em sua comercialização voltada à escola, mas esse formato só aparece impresso com a referida recomendação a partir da segunda edição. Podemos imaginar que uma recomendação oficial para o uso didático deveria elevar as tiragens de determinado livro, fazendo com que o autor vendesse seus direitos por quantias maiores que as convencionais. É freqüente o fato dos livros terem uma capa mais atrativa, assim como ilustrações em seu interior em uma primeira edição, situação essa que se transforma quando se fazem as edições escolares. Assim os livros a serem usados nas escolas apresentam uma capa sem grandes atrativos e perdem grande parte de suas ilustrações. Obviamente essa transformação na materialidade do livro afeta sua recepção por parte dos leitores, tornando-a muito menos prazerosa. Apesar disso, essa parece ter sido uma prática bastante duradoura, pois quando Lobato, em 1921, publica Narizinho Arrebitado em edição escolar, a capa e o miolo do livro passam por modificações semelhantes. Na primeira edição de Narizinho Arrebitado temos um livro de capa dura, bastante atrativa com muitos desenhos feitos por Voltolino em praticamente todas as páginas. Quando essa obra recebe sua edição escolar ela se transforma completamente, a capa deixa de ser feita em cores e recebe apenas um pequeno desenho, também o texto tem poucas ilustrações, provavelmente todas essas mudanças forma feitas com o intuito de baratear a edição do livro.
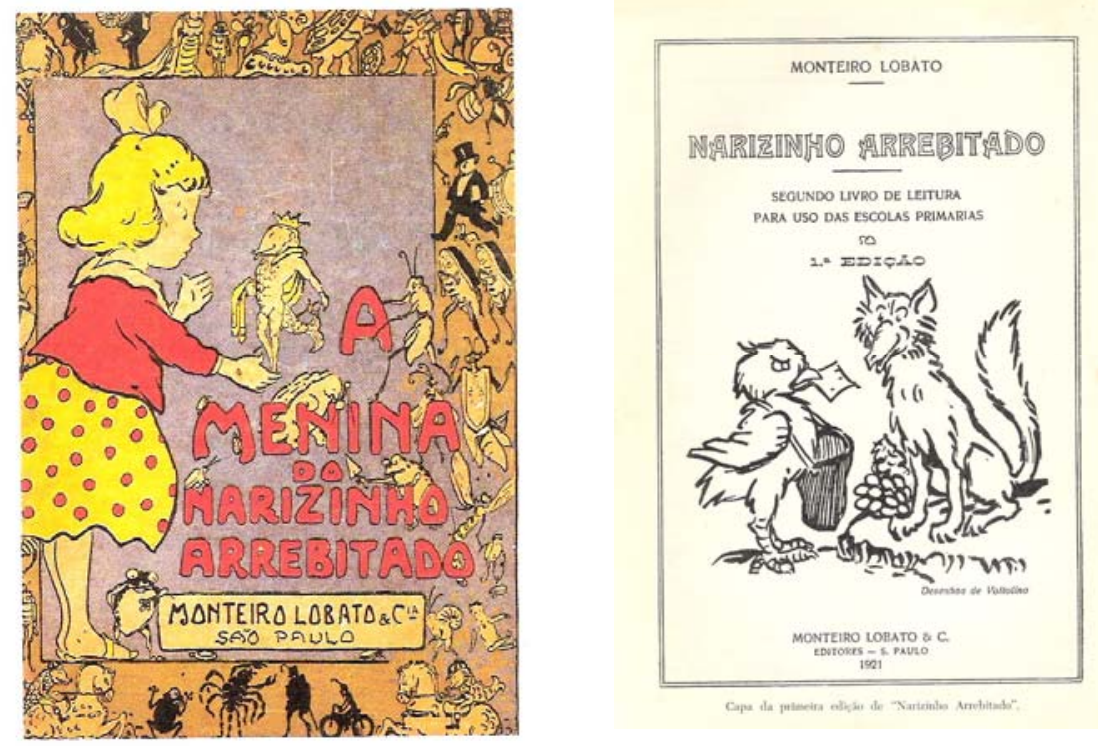

Acervo Seção de Bibliografia e Documentação - BML/PMSP 
o entanto, apesar de materialmente termos uma prática que se perpetua na confecção de livros escolares, em termos de conteúdo a diferença era enorme. Lobato estava preocupado mais em desenvolver o prazer da leitura, mesmo em livros escolares, do que em inculcar em seus leitores uma certa moral piedosa. As situações vividas por seus personagens, principalmente as atitudes de Emília eram irreverentes e audaciosas, sendo por isso tantas vezes criticada por educadores mais conservadores. No entanto, e talvez justamente por essas características, sua obra foi bem recebida pelo público infantil. Assim, na propaganda de Narizinho Arrebitado veiculada na Revista do Brasil temos a seguinte frase: “É um livro fora dos moldes habituaes e feito com o exclusivo intuito de interessar a creança na literatura. O livro que não interessa a creança é um mal: crea o desapego, quando não o horror á leitura”. 49

A diferença era realmente enorme, como podemos notar comparando Narizinho Arrebitado ao livro de Júlia Lopes de Almeida e Adelina Lopes, sua irmã, intitulado Contos Infantis. Em verso e prosa. O desejo de estimular a leitura era comum aos autores, contudo as autoras Júlia e Adelina Lopes escolhem um outro caminho. No conto “A leitura” é narrada a história de um avô, general aposentado, que tendo se tornado cego com a idade, perde todo o ânimo de viver. A protagonista, uma pequena menina que já sabe ler, salva o avô da depressão e da morte lendo para ele histórias de guerras e cenas de batalhas. ${ }^{50}$ A leitura aparece aqui como uma metáfora da visão, quem lê vê o mundo a sua volta, e tem também um papel de salvação, pois o avô, antes condenado, pois não conseguia mais ler, é salvo pela neta, uma pequena criança que adquire esse poder por conta da leitura. No final do conto a criança diz: “- Agora é que eu compreendo bem quanto vale à gente o saber ler.” Não podemos esquecer que este é o momento de uma obsessão pela educação e alfabetização, como foi mostrado por Nicolau Sevcenko, em Literatura como Missão ${ }^{51}$. A ilustração que acompanha o

\footnotetext{
${ }^{49}$ AZEVEDO, Carmen L.; CAMARGOS, Márcia; SACCHETTA, Vladimir. Monteiro Lobato Furacão na Botocundia. São Paulo: Senac ed., 1997. p. 160.

${ }^{50}$ ALMEIDA, Júlia Lopes; VIEIRA, Adelina. Contos Infantis. Em verso e prosa. Adaptados para o uso das escolas primárias do Brasil. 8 ed. Rio de Janeiro; São Paulo: Laemmert e Cia Editores, 1910. p. 4-5.

${ }^{51}$ SEVCENKO, Nicolau. Literatura como Missão. Tensões sociais e criação cultural na Primeira República. 3.ed. São Paulo: Ed. Brasiliense, 1989.
} 
conto é de uma menina, sentada em uma cadeira com uma postura impecável assim como sua vestimenta, com o livro aberto a sua frente. As autoras, no Prólogo à $2^{\text {a }}$ edição, explicam que o livro havia sido aprovado para o uso nas escolas públicas primárias, em 1891, e que possuía a intenção de realizar uma educação moral e também estética. Assim elas definem seu objetivo: "Que uma única das crianças, que nos lerem, pratique, imitando um de nossos heroes, uma ação boa, e ficaremos bem pagas da canceira"52. Não se menciona, nem se sugere, mesmo que pela ilustração o prazer da leitura.

É claro que trinta anos separam a publicação de Contos Infantis e Narizinho Arrebitado, mas como já foi mostrado, uma abundante literatura voltada à criança havia se desenvolvido em outros países, nas décadas finais do século XIX, possibilitando aos autores brasileiros uma opção literária que levava ao prazer da leitura, opção essa que parece não ter se concretizado até o aparecimento de Lobato.

Obras calcadas em valores nacionalistas e de orientação moral continuaram sendo produzidas nas primeiras décadas do século $\mathrm{XX}$, como exemplo temos a obra Através do Brasil, de Olavo Bilac e Manoel Bonfim. Lançada em 1910 pela Francisco Alves, Através do Brasil conta a história de dois irmãos órfãos que são obrigados, por várias contingências, todas elas dramáticas, a viajar pelo Brasil. Por essa narrativa os leitores podiam entrar em contato com a geografia e a história das várias regiões brasileiras, assim como também acompanhavam a trajetória dos dois irmãos. A obra, segundo Marisa Lajolo, pode ser vista como descendente do Bildungsroman, o romance de formação cujo modelo principal deve-se a Goethe, em Os anos de aprendizado de Wilhelm Meister, já que paralelamente aos conhecimentos de história e geografia desenvolve o amadurecimento e crescimento interior dos protagonistas. Esse último era um dos objetivos caros aos autores, como eles próprios explicam na “Advertência e Explicação" que antecede o texto:

\footnotetext{
${ }^{52}$ ALMEIDA, Júlia Lopes; VIEIRA, Adelina Lopes. Contos Infantis. Em verso e prosa. Adaptados para uso das escolas primárias do Brasil. 8.ed. Rio de Janeiro; São Paulo: Laemmert e Cia Editores, 1910. p.VII.
} 
“E também quisemos que este livro seja uma grande lição de energia, em grandes lances de afeto. Suscitar a coragem, harmonizar os esforços, e cultivar a bondade - eis a fórmula da educação humana.(...)"53

No mesmo período temos a publicação de Era uma vez..., escrito por Viriato Correia e João do Rio, com desenhos de Alfredo Norfini, lançado em 1908, também pelo mesmo editor Francisco Alves. Nessa obra os autores reúnem e recriam inúmeras histórias filtradas da cultura popular. Para Andréa Borges Leão, Era uma Vez..., pode ser considerado um marco na literatura de imaginação, pois foge do modelo escolar até então vigente, já que os personagens, crianças e animais, não seguem os princípios de obediência tão comuns nas obras do período, sendo vivos e travessos. ${ }^{54}$

Alguns anos antes, em 1905, a mesma Livraria Francisco Alves havia lançado de Olavo Bilac e Coelho Neto, o livro Theatro Infantil, que reunia pequenas peças escritas para serem encenadas ou recitadas pelas crianças no ambiente familiar. Pelos registros da época era bastante freqüente que as crianças da família criassem pequenas cenas a serem interpretadas para os adultos, assim como também montavam pequenos teatros domésticos de marionetes.

Olavo Bilac foi também o tradutor da obra Juca e Chico, de Wilhem Busch (1832-1908), publicada em alemão em 1865. Essa obra foi traduzida por Olavo Bilac e editada primeiramente em 1901 pela editora Laemmert, em 1911, com a quarta edição, seus direitos passam para a Livraria Francisco Alves. A história ilustrada conta as travessuras de dois meninos, recebeu inúmeras edições apesar de contar uma história repleta de situações improváveis e cruéis, terminando com a punição dos dois meninos. Da mesma forma João Felpudo, de Heinrich Hoffmann, publicada em 1844, recebe sua primeira tradução no Brasil em fins do século XIX, nessa obra as crianças também recebem severos castigos, ora por não tomarem banho, ora por não comerem a sopa. O próprio Monteiro Lobato lembrava-se de na sua infância ter lido e relido “(...) três obras editadas por Laemmert e adaptadas

\footnotetext{
${ }^{53}$ BILAC, Olavo; BOMFIM, Manoel. Através do Brasil: Prática da língua portuguesa. Narrativa. Organização e Introdução de Marisa Lajolo. São Paulo: Companhia das Letras, 2000. p. 46.

${ }^{54}$ LEÂO, Andréa Borges. "Francisco Alves e a formação da literatura infantil” I Seminário Brasileiro sobre o livro e história editorial. Rio de Janeiro: Casa de Rui Barbosa, nov. 2004.
} 
por Jansen Müller, e dois álbuns de cenas coloridas - 'O menino verde' e ‘João Felpudo’.(...) ‘55. Livros como esses eram considerados como álbuns coloridos, sendo que alguns eram feitos com esse propósito, serviam para serem coloridos, outros eram apenas livros de figuras, ou de histórias ilustradas, antecessores das histórias em quadrinhos.

Wilhelm Busch assim como Rodolphe Töpffer(1799-1846) foram os precursores das histórias em quadrinhos, publicando histórias ilustradas com legendas, no formato de livretos e cadernos. Diferentemente, no Brasil, as histórias em quadrinhos surgem no contexto adulto das revistas semanais com a publicação das histórias de Ângelo Agostini: As aventuras de NhôQuim, ou impressões de uma viagem à corte, na revista A Vida Fluminense, de 1869 a 1872, publicada em 15 capítulos, dos quais os nove primeiros foram desenhados pelo autor. Agostini também foi o responsável pela criação de um dos personagens mais importantes do período: Zé Caipora, cujas aventuras foram publicadas irregularmente na Revista Ilustrada, assim como em Dom Quixote e O malho, de 1883 a 1906, totalizando 75 capítulos.

Apesar de terem sido desenhadas para revistas destinadas aos adultos, provavelmente, essas histórias ilustradas devem ter divertido muitas crianças cujos pais eram assinantes. Possivelmente o fato de serem desenhadas e com legendas manuscritas facilitava a leitura ainda titubeante de quem se iniciava no mundo da leitura, os personagens Nhô-Quim e Zé Caipora sendo muito cômicos provavelmente estimulavam ainda mais essa prática, mesmo que por vezes o conteúdo não fosse tão recomendável. Ângelo Agostini foi o autor também de uma história ilustrada intitulada “Crônica para crianças”, publicada no O Malho, em 15 de outubro de 1904. A história possivelmente teve alguma repercussão, pois pouco tempo depois a empresa responsável pela veiculação de $O$ Malho lançará uma das mais importantes publicações voltadas à criança: a revista $O$ Tico Tico ${ }^{56}$.

Contudo, antes do surgimento de $O$ Tico-Tico, vemos surgir em São Paulo, em dezembro de 1904, a revista O Pequeno Polegar, editada pela Livraria Magalhães, tinha como redator Amadeu Amaral e como desenhista

\footnotetext{
${ }^{55}$ CAVALHEIRO, Edgar. Monteiro Lobato. Vida e obra. 3 ed. São Paulo: Brasiliense, 1962.vol I. p.13.

${ }^{56}$ OLIVEIRA, Gilberto Maringoni de. Ângelo Agostini ou impressões de uma viagem da corte à capital federal. São Paulo, FFLCH/USP. Tese de doutorado, 2006.
} 
Alfredo Norfini. Trazia além de textos literários, que abordavam a grandeza do país e a exuberância de suas matas, curiosidades, jogos de adivinhações e competições literárias e parece ter tido uma efêmera duração. ${ }^{57}$

Em 11 de outubro de 1905, é lançado o primeiro número de O Ticotico inspirado em periódicos voltados à infância que se tornavam freqüentes na Europa, como o semanário francês La semaine de Suzette. A revista era composta por histórias em quadrinhos, charadas, passatempos e contos e fazia a alegria das crianças, com personagens como: Chiquinho, Jagunço, Reco-reco, Bolão, Azeitona - entre muitos outros. ${ }^{58}$ Apesar de ter sido o periódico de mais sucesso, e mais longevidade no país, existiram também outras revistas que possuíam algumas semelhanças com O Tico-Tico, mas também tinham suas especificidades.

Entre elas temos a revista O Picapau publicada pela mesma Livraria Magalhães, que havia feito uma primeira incursão na imprensa para crianças com a já citada $O$ Pequeno Polegar. O primeiro número de O Picapau aparece em março de 1908, tendo 32 páginas, sendo que as 8 últimas eram somente anúncios da casa que a editava, veiculava contos e poesias de Coelho Netto, Olavo Bilac, Presciliana Duarte e Julia Lopes de Almeida. A impressão de fotos desta revista merece ser destacada pela qualidade, bastante superior a da revista $O$ Tico-Tico. Logo no primeiro número são divulgadas fotos de um baile carnavalesco realizado no Club Internacional, o fotógrafo: Valério Vieira retratou as crianças filhas da elite paulista da época, todas primorosamente fantasiadas. Ainda na mesma revista aparece a conhecida foto feita por ele intitulada "Os Trinta Valérios”. O acervo da Biblioteca Monteiro Lobato tem somente os quatro primeiros números, e não foi possível nesta pesquisa determinar sua permanência. É interessante notar que apesar da tiragem ser de 15.000 exemplares deveria ser difícil sua comercialização, tal é a quantidade de prêmios e recompensas dadas a quem conseguir uma lista de subscrições e também devido a quantidade de prêmios que eram distribuídos aos assinantes.

\footnotetext{
${ }^{57}$ MARTINS, Ana Luiza. Revistas em revista: imprensa e práticas culturais em tempos de república. São Paulo: EDUSP; FAPESP; Imprensa Oficial, 2001.

${ }^{58}$ PAULA ROSA, Zita de. O tico-tico, meio século de ação recreativa e pedagógica. Bragança Paulista: Ed. Universidade de São Francisco, 2002.
} 
Outras revistas foram lançadas nas primeiras décadas do século XX, como Juquinha, publicação semanal carioca, lançada em 1912, que parecida com O Tico-Tico veiculava quadrinhos coloridos, anedotas, brinquedos para montar, textos e folhetins e fotos de seus leitores. O Beija-flor revista publicada em Petrópolis, de 1915 a 1918 trazia somente a capa colorida e tinha cerca de 20 páginas que traziam textos onde a moral cristã aparecia com mais força do que em outras publicações, além de charadas, passatempos, concursos e brincadeiras. ${ }^{59}$
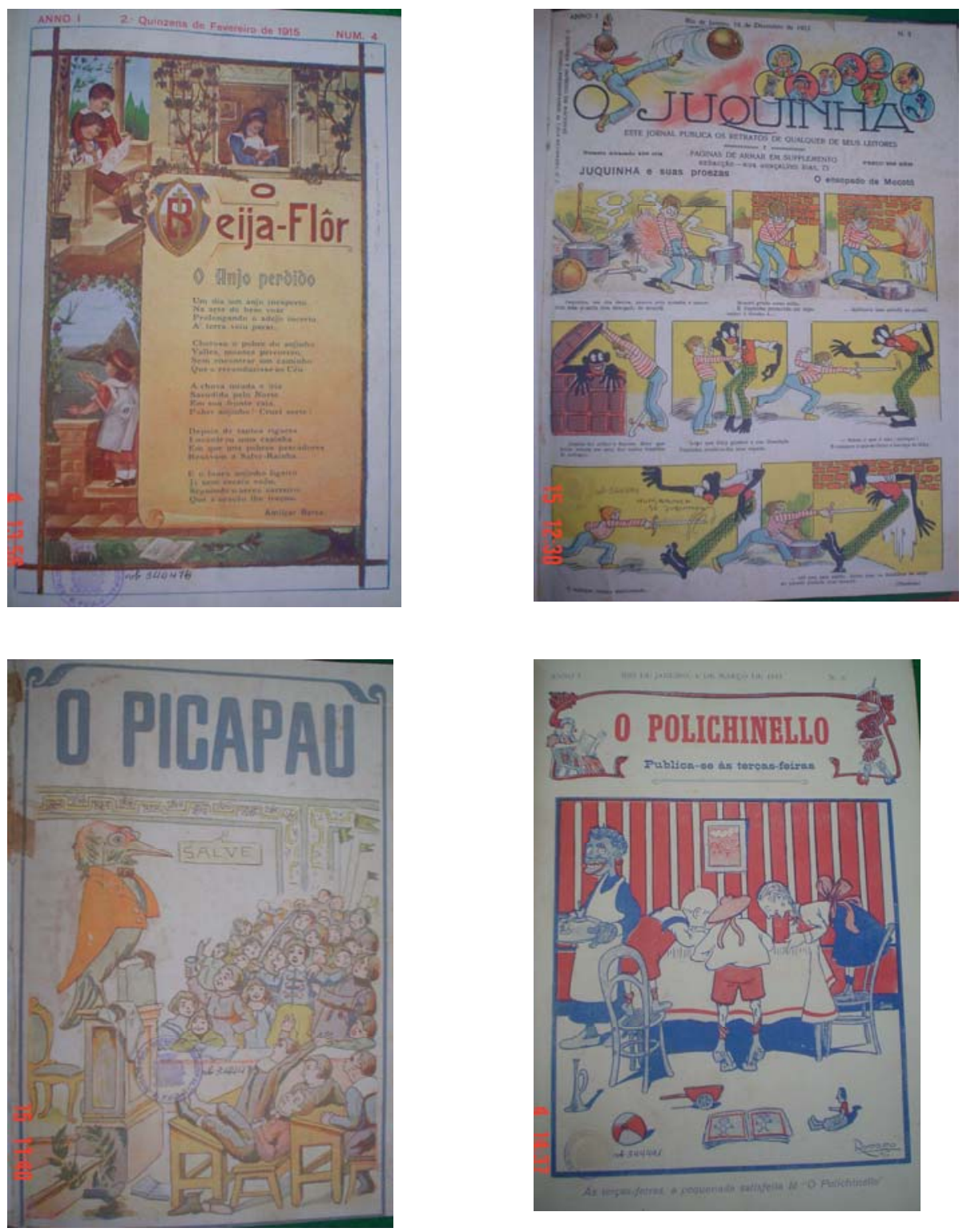

\footnotetext{
${ }^{59}$ As revistas citadas nesse capítulo foram consultadas no acervo de Bibliografia e Documentação da Biblioteca Municipal Monteiro Lobato. Como essas revistas não foram encontradas em outro acervo não nos foi possível determinar com exatidão se elas continuaram existindo em outros anos que não foram citados.
} 
A imprensa voltada à infância parece ter conhecido um grande crescimento nas três primeiras décadas do século, já no período que compreende as cartas enviadas pelos leitores a Monteiro Lobato, temos uma relação de revistas que foram consideradas por Lenyra Fraccarolli, diretora da Biblioteca Infantil, apropriadas para as crianças. A listagem traz doze títulos, sendo que um deles vinha da Argentina, era a revista Biliken. ${ }^{60}$ Dentre os títulos brasileiros estão incluídos O Tico-tico, Bem-te-vi, Vida Infantil e Era uma Vez... revista publicada em Belo Horizonte, por Vicente Guimarães, que usava o pseudônimo de Vôvo Felício para assinar inúmeros livros infanto-juvenis ${ }^{61}$. Além das revistas semanais ou mensais, na época, as crianças contavam também com suplementos especialmente dedicados a elas que saíam em alguns jornais, como a Gazeta Infantil, publicada pela Gazeta, ou O Guri, publicada pelo Diário da Noite. Na década de 30 temos também o surgimento e enorme crescimento da publicação de histórias em quadrinhos, que serão posteriormente chamadas pelo título de uma das mais representativas: Gibi. O enorme desenvolvimento de uma imprensa voltada exclusivamente para histórias em quadrinhos fez com que pedagogos, bibliotecários, professores e até mesmo as crianças discutissem sua influência nos hábitos de leituras das crianças. Gonçalo Júnior, em sua obra A guerra dos Gibis mostra como desde o seu surgimento os gibis suscitaram opiniões apaixonadas, contra e a favor deste gênero voltado à infância. As próprias crianças se posicionaram no Congresso de Escritores Infantojuvenis, como veremos mais adiante neste trabalho.

De certa forma podemos pensar que a obra de Lobato vai dialogar com a imensa divulgação das histórias em quadrinhos, pois o próprio Gato Félix, veiculado pela revista O Tico-Tico, aparece diversas vezes no sítio do Picapau Amarelo, mesmo que às vezes sob suspeita, pois todos no sítio desconfiavam que aquele gato era um falso Gato Félix. A obra de Lobato vai também ser construída a partir de outros personagens do universo infantil, que vão das princesas dos contos de fadas tradicionais aos personagens das fitas cinematográficas da época, como Tom Mix, passando

\footnotetext{
${ }^{60}$ A revista Biliken foi analisada por Gabriela Pelegrino Soares em Semear Horizontes. Belo Horizonte: Ed. UFMG, 2007.

${ }^{61}$ Listagem feita por Lenyra Fraccarolli. Caderno: Diversos 1936. Acervo de Bibliografia e Documentação. Biblioteca Municipal Monteiro Lobato.
} 
por personagens criados por outros autores como Pinóquio e Peter Pan. As cartas escritas pelas crianças assim como o jornal A Voz da Infância, por vezes, também comentarão esse universo das personagens que transita por meios tão diferentes, dos quadrinhos ao cinema, passando pelos contos de fadas tradicionais e obras literárias estrangeiras.

O período que compreende esta pesquisa deve ser analisado tendo-se em vista que o universo no qual a criança desenvolvia suas atividades cotidianas era já muito diferente do universo vivenciado no século XIX. O rádio, o cinema, as histórias em quadrinhos, as revistas e os livros publicados especialmente para esse público se desenvolviam plenamente, fazendo com que a criança das décadas de 30 e 40 tivesse uma ampla gama de produtos culturais voltados a ela.

Monteiro Lobato construía suas obras se apropriando e dialogando com esse universo. Quando em Geografia de Dona Benta, os personagens chegam aos Estados Unidos da América do Norte, um dos desejos das crianças era conhecer Hollywood e seus estúdios: Emília visita Shirley Temple, Tia Nastácia cozinha para as estrelas do cinema. Pedrinho quando quer ter notícias do Brasil, sintoniza alguma rádio através das ondas curtas. Talvez essa forma peculiar de incorporar elementos do cotidiano infantil à narrativa tenha sido um dos fatores de seu imenso sucesso. No entanto, Lobato não deixa de fazer referências aos autores de cada país, assim em Geografia de Dona Benta temos a citação de inúmeros livros de autores clássicos, muitos deles traduzidos por Lobato, como Kipling, Jack London, Mark Twain, Emílio Salgari, Julio Verne, Alexandre Dumas e Andersen. Isso também era freqüente em outras obras, como por exemplo: em Aritmética da Emília, onde Lobato coloca Dona Benta lendo para os netos o livro O homem que calculava, de Malba Tahan, autor de muito sucesso no período estudado. Outros autores como Thales de Andrade e Viriato Correa serão também citados tanto nas obras de Lobato como nas cartas das crianças. Dessa forma Lobato tecia ligações entre o universo cotidiano da criança e também a remetia ao universo da leitura, estimulando sua curiosidade com relação à leitura de obras literárias de autores estrangeiros e nacionais. 
Assim, ao ler um livro de Monteiro Lobato a criança tinha acesso a um universo literário maior, a leitura levava a outras leituras. Evidentemente a construção de uma obra com tais características fazia parte do projeto do autor de formação de cidadãos para a nação. Por meio dos livros infantis Lobato pretendia criar leitores, que no futuro transformariam o Brasil em uma nação moderna. Fazer com que suas obras fossem divertidas e que dialogassem com as novas tecnologias, além de incluir personagens vindos desses meios, era um dos recursos utilizados pelo autor.

Mas de que forma essas obras eram percebidas pelas crianças? As cartas escritas pelas crianças leitoras a Monteiro Lobato, em certa medida, elucidam alguns dos aspectos dessa prática. Se os livros possibilitavam uma fuga da realidade em que viviam, se motivavam a transformação dessa mesma realidade ou se constituíam, em si, uma realidade possível para as crianças é o que veremos no capítulo a seguir. 


\section{Pirlimpimpim pelo correio}

"Eu me adimiro como você tem tempo de responder a todas as cartinhas.”

João Alphonsus de Guimarães Filho

\section{O tesouro particular de Lobato}

A dificuldade maior em se trabalhar com o contingente de cartas enviadas pelos leitores a Monteiro Lobato não se deve somente ao fato de serem elas numerosas ${ }^{62}$, mas sobretudo, pelo dado concreto de, em cada uma delas, existir todo um universo a ser abordado e analisado. Tabelas que mostram os assuntos a que as cartas se referem pouco auxiliariam na compreensão mais aprofundada de como a leitura dos textos era feita na infância, de quais seriam os temas preferidos e indícios possíveis de como essa leitura transformava a vida das crianças. As cartas dificilmente tocam em um único assunto, a grande maioria, mesmo as escritas em um contexto escolar, deixam entrever o cotidiano de vida dessas crianças, suas leituras preferidas, seus desejos pessoais, a relação que tinham com pais, familiares e amigos.

As cartas preservadas no Arquivo Raul de Andrada e Silva, no dossiê Monteiro Lobato, do Instituto de Estudos Brasileiros (IEB/USP) compreendem o período que vai de 1932 a $1946 .{ }^{63}$ O período de tempo compreendido por esta documentação está balizado por duas viagens importantes na vida de Monteiro Lobato. Em março de 1931, ele retorna de sua estadia como adido comercial do governo brasileiro em Nova York,

\footnotetext{
${ }^{62}$ As cartas que constituem grande parte do corpo documental desta pesquisa estão preservadas quase que em sua totalidade no Arquivo do Instituto de Estudos Brasileiros. São 321 cartas, tendo sido catalogadas como: 246 cartas de crianças e 75 de adultos. No decorrer da tese elas serão citadas tal qual o original, mantidos os erros ortográficos e de acentuação.

${ }^{63}$ Existe somente uma carta, em toda a documentação pesquisada no Instituto de Estudos Brasileiros, cuja data no cabeçalho está 1926, mas escrito de forma rasurada, sendo que provavelmente a data é de 1936, se levarmos em conta que dificilmente uma única carta anterior a viagem a Nova York teria sido preservada pelo autor. Também foi encontrada uma carta não datada no mesmo arquivo, que provavelmente é de 1929, escrita por Alariquinho (Cx 1 P 2 doc 3) parece ser a resposta a uma carta publicada de Lobato, de setembro de 1929, ver Cartas Escolhidas, $1^{\circ}$ tomo, p 292- 293.
} 
fixando sua residência em São Paulo, e em junho de 1946, ele e sua família, mudam-se para Buenos Aires, onde permanecem por quase um ano.

Esses dois marcos temporais são bastante significativos na biografia de Lobato. Em Nova York ele passa pouco mais de quatro anos, de 1927 a 1931. Como adido comercial ele procura alternativas possíveis para o crescimento brasileiro, suas buscas dirigem-se principalmente a processos para a obtenção do ferro e do petróleo, que em sua opinião levariam o país ao desenvolvimento, já alcançado pela nação norte-americana. No segundo momento temos Lobato transferindo-se para Buenos Aires, em junho de 1946. As dificuldades econômicas parecem ter sido o principal motor que levou o autor a se transferir para o país vizinho. Como suas obras completas haviam sido publicadas pela Americalee, ele contava com recursos na Argentina que não podiam ser transferidos para o Brasil, pelo menos é o que sugere a carta enviada a Rangel:

"Creio que me tornei comum de dois paises, pois vivo de livros e os que tenho aqui em exploração os terei lá, todos, este ano. Cada livro considero uma vaca holandesa que me dá o leite da subsistência. O meu estábulo no Brasil conta com 23 cabeças no Octales, mais 12 na Brasiliense e mais as 30 Obras Completas. Total 65 vacas de 40 litros. E o meu estábulo na Argentina conta com 37 cabeças. Grande total lá e cá: 102 cabeças. O produto do leite vendido na Argentina (e mais paises hispânicos) fica depositado lá mesmo, de modo que para mim uma temporada lá não tenho que recorrer ao leite daqui.",64

Tendo residido na capital portenha por quase um ano, Monteiro Lobato retorna a São Paulo em Junho de 1947. Como veremos a seguir, o escritor, mesmo residindo na Argentina continuava a receber cartas de leitores, no entanto estas cartas parecem não ter sido preservadas e temos delas somente o registro no jornal A Voz da Infância.

No Arquivo Raul de Andrada e Silva encontramos ainda uma carta de Lobato a Marina Andrada Procópio de Carvalho, datada de maio de 1946, por meio da qual percebemos que ele está organizando seu arquivo e a

${ }^{64}$ MONTEIRO LOBATO. Barca de Gleyre: quarenta anos de correspondência literária entre Monteiro Lobato e Godofredo Rangel. 8.ed. São Paulo: Ed. Brasiliense, 1957. tomo II, p. 374. 
encaminha à Marina com alguns outros documentos, que ficaram preservados junto à correspondência pesquisada.

"Marina:

Hoje, 11 de maio de 1946, passei a manhã destruindo papeis velhos. Encontrei um antigo caderno de notas que só eu entendo e tive a idéia, em vez de destruí-lo, de dá-lo á boa amiga, como curiosidade. E bati esta copia das notas, com algumas observações esclarecedoras. Nessas notas, aparecem os germes de varias coisas que escrevi - inclusive o ‘começo’ de narizinho - o olho d'agua da minha literatura infantil. É um caderno-documento.”65

Antes de sua ida à Argentina, Lobato, encarregou-se de distribuir seu arquivo e biblioteca, entre familiares e amigos próximos. Possivelmente esse arranjo possibilitava ao autor a preservação de seus documentos, pois ele acreditava que sua mudança para o país vizinho seria por um longo tempo. Edgard Cavalheiro nos conta como isso aconteceu:

“Logo após a publicação de ‘A Barca de Gleyre’, ele apareceu uma noite. Não quis jantar. Ficou rodeando a mesa, beliscando coisas. Reclamou da casa. Muito pequena. Uma lata de sardinhas. Os livros andavam amontoados, por todos os cantos. Não se podia colocar mais nada ali. Foi ao escritório. Voltou. Como que estava a medir com os olhos os metros ou centímetros quadrados disponíveis. Por fim, esclareceu que ia mesmo de mudança para a Argentina. Talvez não voltasse. Tinha uma papelada imensa que de nada lhe servia, mas que lamentava botar fora, pois talvez se prestasse para reconstituir certa época de vida literária brasileira. (...) Finalmente parou e olhando-me firme, fez a pergunta que sem dúvida trouxera engatilhada:

- Quer ficar com meu arquivo?»66

Dessa forma a documentação pessoal de Monteiro Lobato ficou em parte com a família e em parte com amigos muito próximos, e percorreu um itinerário bastante peculiar até chegar aos dias de hoje, preservada em

\footnotetext{
${ }^{65}$ Instituto de Estudos Brasileiros. Arquivo Raul de Andrada e Silva. Dossiê Lobato. Cx 3.

${ }^{66}$ CAVALHEIRO, Edgard. Monteiro Lobato, Vida e Obra. 3.ed. São Paulo: Ed. Brasiliense, 1962. p. 3. $1^{\circ}$ tomo.
} 
algumas instituições públicas. A documentação que ficou sob a responsabilidade de Marina de Andrade Procópio de Carvalho, cartas de leitores, documentos pessoais e o caderno-documento, após a sua morte, foi conservada junto ao Arquivo de Raul de Andrada e Silva (ARAS), seu tio e professor do departamento de História da Universidade de São Paulo, sendo posteriormente doada pelos herdeiros para o IEB. Parte da documentação pessoal como os álbuns de recortes, feitos por Purezinha, esposa de Lobato, parte da biblioteca do autor, cadernetas de telefone, assim como objetos de uso pessoal, desenhos e quadros, foram doados pela viúva à Biblioteca Municipal Infanto-Juvenil, que recebeu o nome de Monteiro Lobato, e encontra-se atualmente em uma seção especializada em sua preservação. Recentemente a família do autor encaminhou ao Centro de Documentação Alexandre Eulálio, CEDAE/UNICAMP, cartas de correspondência ativa e passiva que estavam ainda em sua posse, além de cartões postais, aquarelas e quadros. Assim sendo, a documentação ao ser fragmentada ainda em vida pelo próprio Monteiro Lobato, percorreu caminhos sinuosos conseguindo ser, em parte, preservada.

Deste modo, as cartas de leitores concentram-se no arquivo do IEB, enquanto nas outras instituições mencionadas encontramos documentos que completam essa correspondência ou auxiliam a sua compreensão. Verificamos, procedendo à leitura e transcrição das cartas, que a organização do arquivo, tendo separado as cartas de crianças das cartas de adultos, foi em certa medida deficiente, pois não se percebeu que muitas delas classificadas em um primeiro momento como sendo de adultos não o eram. Muitas cartas classificadas como de adultos eram de fato a continuação de uma correspondência começada na infância e que se prolongou até a juventude destes leitores. Dessa forma, foi necessário ler e transcrever todas as cartas, assim trabalhamos com todo o conjunto de cartas preservadas e não somente com as que foram catalogadas como sendo de crianças leitoras. Foi também uma grata surpresa descobrir nos outros acervos mencionados a continuação da correspondência, ou uma resposta de Lobato aos leitores.

Durante a pesquisa com a correspondência verificou-se também que a transcrição das cartas em sua íntegra possibilitava uma compreensão muito 
mais aprofundada não só do que era comentado, mas da forma pelas quais as crianças construíam sua escrita. Assim durante vários meses da pesquisa nos dedicamos ao trabalho árduo de transcrever os documentos, e fomos aos poucos incorporando a linguagem utilizada pelas crianças e jovens, assim como também a maneira como os leitores compunham a carta enviada. Talvez sem essa etapa de transcrição dos documentos não teríamos notado nas cartas certas nuances, tons e eventuais tópicos que fizeram muita diferença possibilitando um trabalho mais acurado.

As cartas que os leitores escreveram para Monteiro Lobato já foram comentadas em várias publicações. Em sua clássica biografia: Monteiro Lobato, vida e obra, Edgard Cavalheiro as comenta por mais de dez páginas. Utilizando trechos das cartas das crianças, e também as respostas de Lobato a estas cartas, respostas essas que hoje não encontramos preservadas. Nessas páginas, Edgard Cavalheiro mostra a importância que Lobato dava às cartas recebidas de leitores e como a obra de Lobato era importante dentro do contexto da leitura infanto-juvenil, mesmo tendo sido perseguida e censurada em inúmeros colégios e pelo governo federal.

“As crianças realmente acreditaram nele, e constituiram-lhe os 'grandes prêmios' da vida. Ninguém dizia com inocultável orgulho, recebera mais prêmios do que ele. Que prêmios eram esses? As cartinhas que de todas as partes do Brasil e da América Latina lhe chegavam diariamente as mãos. Chega a ser comovente ler a enorme correspondência da petizada. Em geral ligeiros bilhetes, que levam uma palavra de aplauso ao homem que proporcionou alguns momentos de felicidade ao guri enfastiado com as maçantes histórias dos livros didáticos. A letra irregular, deliciosamente infantil (muitas vezes a lápis), o papel pequeno, que a mamãe trouxe da cidade especialmente para esse fim, a sem-cerimônia do tratamento, a pontuação inteiramente arbitrária e a ingenuidade sem intenções, fazem dessas cartinhas pequenos poemas em prosa." 67

\footnotetext{
${ }^{67}$ CAVALHEIRO, Edgard. Monteiro Lobato, vida e obra. 3 ed. São Paulo: Ed. Brasiliense, 1962. $2^{\circ}$ tomo. P. 172.
} 
A partir dos trechos transcritos na biografia podemos perceber que Cavalheiro teve acesso ao conjunto das cartas de crianças, hoje no arquivo IEB/USP, mas que também utilizou algumas das respostas que Lobato escreveu para as crianças leitoras. Infelizmente as respostas mencionadas por Cavalheiro não tiveram o mesmo destino das cartas de leitores e não puderam ser encontradas. No entanto algumas respostas estão ainda nas mãos dos leitores que se corresponderam com o escritor e que foram assunto da tese de doutorado de Eliane Debus.

Nessa tese de Doutorado, publicada posteriormente como livro: Monteiro Lobato e o leitor, esse $\operatorname{conhecido}^{68}$ a autora analisa a correspondência trocada entre Lobato e seus leitores como uma das formas que Lobato se utilizou para fomentar seu projeto de formação de leitores. Eliane Debus trabalha não só as cartas, mas também as visitas às escolas, as entrevistas e outras ações como parte de um projeto de Lobato para a criação de um público leitor. Seguindo essa idéia Eliane Debus entra em contato e entrevista sete leitores de Lobato, sendo que seis dentre eles se corresponderam na infância com o autor tendo suas cartas preservadas no arquivo já mencionado. Os depoimentos dados mais de sessenta anos após a correspondência mostram a importância que a obra de Lobato teve na vida destes leitores, revelando muitas vezes detalhes que explicam a correspondência.

A dissertação de mestrado de Marco Antônio B. Edreira, À caça do sentido $^{69}$, defendida na área de História e Historiografia da Faculdade de Educação, da Universidade de São Paulo, pretende também compreender as práticas de leitura por meio da correspondência trocada entre Lobato e seus leitores infantis. $\mathrm{O}$ autor trabalhou com as cartas dando ênfase, principalmente, à relação existente entre a leitura e a instituição escolar, apontando para os usos escolares que os livros escritos por Lobato tiveram. As cartas, classificadas por Edreira, como Escolares, mostravam como os leitores associavam o aprendizado feito pelos livros de Lobato e o adquirido nos bancos escolares.

\footnotetext{
${ }^{68}$ DEBUS, Eliane. Monteiro Lobato e o leitor, esse conhecido. Florianópolis: Ed. UFSC, 2004.

${ }^{69}$ EDREIRA, Marco Antônio Branco. À caça do sentido. Práticas de leitura de leitores de Monteiro Lobato: um estudo da cartas infanto-juvenis (1926-1946). São Paulo: Universidade de São Paulo, 2003. Dissertação de Mestrado - Faculdade de Educação.
} 
Na biografia escrita por Carmen Lúcia de Azevedo, Márcia Camargos e Vladimir Sacchetta, Monteiro Lobato Furacão na Botocúndia ${ }^{70}$ as cartas de leitores são abordadas em um capítulo intitulado: "Despertador do BrasilCriança”. Nesse capítulo os autores abordam como as cartas de leitores mostram o poder transformador da literatura infanto-juvenil de Monteiro Lobato, citando vários trechos das cartas do acervo IEB, apontam para o fato dos leitores comentarem o quanto a leitura de seus livros fazia com que eles vissem o mundo de forma diferente.

Toda a bibliografia e os biógrafos concordam com o fato dessa documentação ter tido uma imensa importância para o escritor. Repetidas vezes, ele menciona em cartas a amigos e entrevistas que as cartas constituíam sua recompensa, seu tesouro particular. Em carta a Godofredo Rangel, de 28 de março de 1943, Lobato comentava o sucesso nas vendas de suas obras infantis e escrevia sobre a importância que as cartas de leitores possuíam para ele citando uma carta recebida:

“Ah. Rangel, que mundos diferentes, o do adulto e o da criança! Por não compreender isso e considerar a criança 'um adulto em ponto pequeno', é que tantos escritores fracassam na literatura infantil e um Andersen fica eterno. Estou nesse setor há já vinte anos, e o intenso grau da minha 'reeditabilidade' mostra que o meu verdadeiro setor é esse. A reeditabilidade dos meus livros para adultos é muito menor. Não posso dar a receita. Entram em cena imponderáveis inapreensíveis. A carta desta menina revela todo um mundo para o psicólogo. E cartas assim constituem os verdadeiros prêmios que possa ter um escritor no fim da vida.”

Logo em seguida, Lobato transcreve para o amigo a carta de uma leitora. No entanto, comparando-se a carta original, preservada no arquivo IEB/USP, com a transcrita para Rangel e posteriormente publicada na Barca de Gleyre, vemos que Lobato teve o cuidado de suprimir o trecho no qual a leitora se descreve. E, provavelmente, com o intuito de preservar a identidade da leitora troca também a inicial com a qual ela assinou a carta ${ }^{71}$.

\footnotetext{
${ }^{70}$ AZEVEDO, Carmen L.; CAMARGOS, Márcia; SACCHETTA, Vladimir. Monteiro Lobato Furacão na Botocundia. São Paulo: Senac ed., 1997. p. 332.

${ }^{71}$ Carta de Sarita (S. A. M.). São Paulo, 26/04/1943. IEB/USP. ARAS. Cx 1 P 2 doc 44.
} 
Assim ele terminava a carta refletindo sobre a importância que a obra infantil tinha no final de sua vida:

“Quando, ao escrever a história de Narizinho, lá naquele escritório da Rua Boa Vista, me caiu do bico da pena uma boneca de pano muito feia e muda, bem longe estava eu de supor que iria ser o germe da encantadora Rainha Mab do meu outono.”72

Na carta seguinte ao mesmo amigo, de 24 de agosto de 1943, ele comenta mais uma carta recebida agora do pai de um leitor, que escreve agradecendo a carta que Lobato havia escrito ao menino que, tendo uma doença grave, havia melhorado em virtude da carta recebida ${ }^{73}$ :

“(...) Um pai escreveu-me: 'Com os meus agradecimentos pela cartinha que o senhor mandou em resposta a meu filho Lindbergh, dou-lhe notícia de que a missiva está concorrendo enormemente para a cura do rapaz. Diz ele que ontem foi um dos dias mais felizes de sua vida.' O menino estava no fundo da cama, convalescendo de doença grave, e minha carta fe-lo melhorar... Ora, evidentemente este sujeito taumaturgo vale muito mais que aquele magister dixit de Taubaté.”74

Por este trecho podemos perceber que a recepção de uma carta de Lobato tinha um poder enorme e poderia ser o motivo da melhora na saúde da criança. Tanto nesta carta como na que será citada abaixo vemos também que o escritor tinha uma postura bastante irreverente quando se tratava de falar do ensino institucionalizado.

Assim em carta de 5 de março de 1945, Lobato volta a comentar sobre as cartas de leitores, e solicita a Rangel uma “ajuda” para resolver o problema da leitora:

“(...) Como é interessante a minha correspondência! Não imaginas as cartas que recebo das crianças. Junto uma que me devolverás. A coitadinha, desesperada com o pedantismo dos programas oficiais, recorre a mim para que peça a Dona Benta que

\footnotetext{
${ }^{72}$ MONTEIRO LOBATO. Barca de Gleyre: quarenta anos de correspondência literária entre Monteiro Lobato e Godofredo Rangel. 8.ed. São Paulo: Ed. Brasiliense, 1957. tomo II, p. 347.

${ }^{73}$ Carta de Lindenbergh R. Faria. São Paulo, 04/08/1943. IEB/ARAS. Cx 2 P 1 doc 25.

${ }^{74}$ MONTEIRO LOBATO. Barca de Gleyre: quarenta anos de correspondência literária entre Monteiro Lobato e Godofredo Rangel. 8.ed. São Paulo: Ed. Brasiliense, 1957. tomo II, p.350.
} 
lhe explique o ponto. Ora, como eu não sei gramática, sou obrigado a recorrer a uma e aprender o que ela quer que D. Benta explique, 'Regência dos verbos mais frequentes'. Eu devo fazer isso muito bem, mas não ligo nome à pessoa. Antigamente você me resolvia as dúvidas gramaticais, quem sabe se ainda tem animo de me explicar isso? Porque se eu for ver na gramática sou até capaz de não achar, de tal modo eu me perco naquele baratro.”75

Além de mobilizar o amigo Rangel para auxiliar nas questões gramaticais, Lobato destaca o fato de que a carta da leitora, que ele envia junto a sua, deveria ser devolvida. Mais um indício de que Lobato tinha uma preocupação especial na conservação das cartas de leitores ${ }^{76}$.

No ano seguinte, já morando em Buenos Aires, Lobato escreve comentando as cartas recebidas de leitores argentinos, e se diverte com o fato de sua entrevista e um trecho de uma carta de criança ter sido publicado em um dos jornais mais sisudos da capital argentina:

"Por falar em Prensa. Não há no mundo jornal mais circunspecto e rigorista. Não ri nem sorri. É mais que gravidade; chega a ser gravidez. Pois bem na noticia que deu a respeito da visita que como velho colaborador, lhe fiz, referiu-se as cartas de crianças que tenho recebido cá e citou o pedacinho duma- em que uma niña de Santa Fé me pede que lhe mande uma pílula do Dr. Caramujo para curar de mudez congenitora uma boneca a que ela deu o nome de Emilia.

O Dr. Caramujo aqui virou na tradução, Doutor Cara de Col (Caracol), e as pílulas viraram 'pastilhas'. E eu achei muita graça em ver aparecer nas graverrimas colunas da 'Prensa' as Pastilhas del Dr. Cara de Col, que eles lá no jornal absolutamente não sabem o que é...,77

\footnotetext{
${ }^{75}$ MONTEIRO LOBATO. Barca de Gleyre: quarenta anos de correspondência literária entre Monteiro Lobato e Godofredo Rangel. 8.ed. São Paulo: Ed. Brasiliense, 1957. tomo II,, p. 366.

${ }^{76}$ A carta mencionada por Lobato a Rangel é provavelmente a carta de Wanda Côrtes. Juiz de Fora, 22/02/1945. IEB/USP. ARAS. Cx 1 P 3 doc 26.

${ }^{77}$ MONTEIRO LOBATO. Barca de Gleyre: quarenta anos de correspondência literária entre Monteiro Lobato e Godofredo Rangel. 8.ed. São Paulo: Ed. Brasiliense, 1957. tomo II, p. 380-381.
} 
Como vemos a correspondência de Lobato com seus leitores, especialmente as cartas escritas por crianças sempre foram valiosas para o escritor e frequentemente apareciam em entrevistas que o autor dava para jornais e revistas como no caso do Jornal portenho, mas também em diversos outros veículos como na Revista Diretrizes ${ }^{78}$. Até mesmo no jornal organizado pelas crianças frequentadoras da Biblioteca Municipal InfantoJuvenil, A Voz da Infância, pode-se ver reproduzidas duas cartas de leitores para o autor: uma de uma menina de Piracicaba, em setembro de 1946 e outra de outubro do mesmo ano de Ituzaingó, Argentina. ${ }^{79}$

Desse modo percebemos durante a pesquisa que a conservação e a possibilidade de atualmente consultarmos grande parte da correspondência enviada por leitores a Monteiro Lobato não foi casual. Parece mesmo ter sido planejada pelo escritor, que tomou cuidados para que ela fosse preservada, sendo que ele próprio frequentemente comentava as cartas e seus conteúdos. Apesar de Lobato ter sido muito conhecido, editado e lido, no período estudado, parece que ele ainda necessitava de uma prova concreta de que sua literatura era útil, transformava seus leitores, surtia efeito. Além disso, as cartas eram repletas de afetividade e opiniões inusitadas sobre sua obra, justificando também o zelo com a qual o autor preservou a correspondência enviada por leitores.

\section{A materialidade das cartas}

Primeiramente seria interessante discorrer um pouco sobre a materialidade das cartas e envelopes que constituem o corpo documental deste trabalho, pois ela nos fornece informações preciosas sobre o leitor e a correspondência. Percebemos na consulta ao material que existe uma diversidade de suportes para a carta, algumas são escritas em papel especial para uma correspondência infantil, em formato menor que o usual, com decorações específicas que aludem a escrita infantil. Não sabemos se esses

\footnotetext{
${ }^{78}$ MONTEIRO LOBATO. “Um Governo deve sair do Povo como o fumo sai da fogueira” In: Prefácios e entrevistas. $8^{\mathrm{a}}$ ed. São Paulo, Brasiliense, 1957. p. 155-180.

${ }^{79}$ Essas cartas não se encontram no arquivo do IEB/USP, pois foram enviadas a Lobato quando da sua residência em Buenos Aires, não foram também encontrados seus originais em nenhum outro acervo pesquisado. A Voz da Infância. No. 145. São Paulo, julho de 1948. p 3-4.
} 
papéis de carta eram fabricados no país ou eram importados, mas eles são pautados, com desenhos em policromia, quase sempre localizados no canto superior esquerdo. Os desenhos referem-se às crianças em mesas de escrever, ou fazendo alguma atividade infantil.
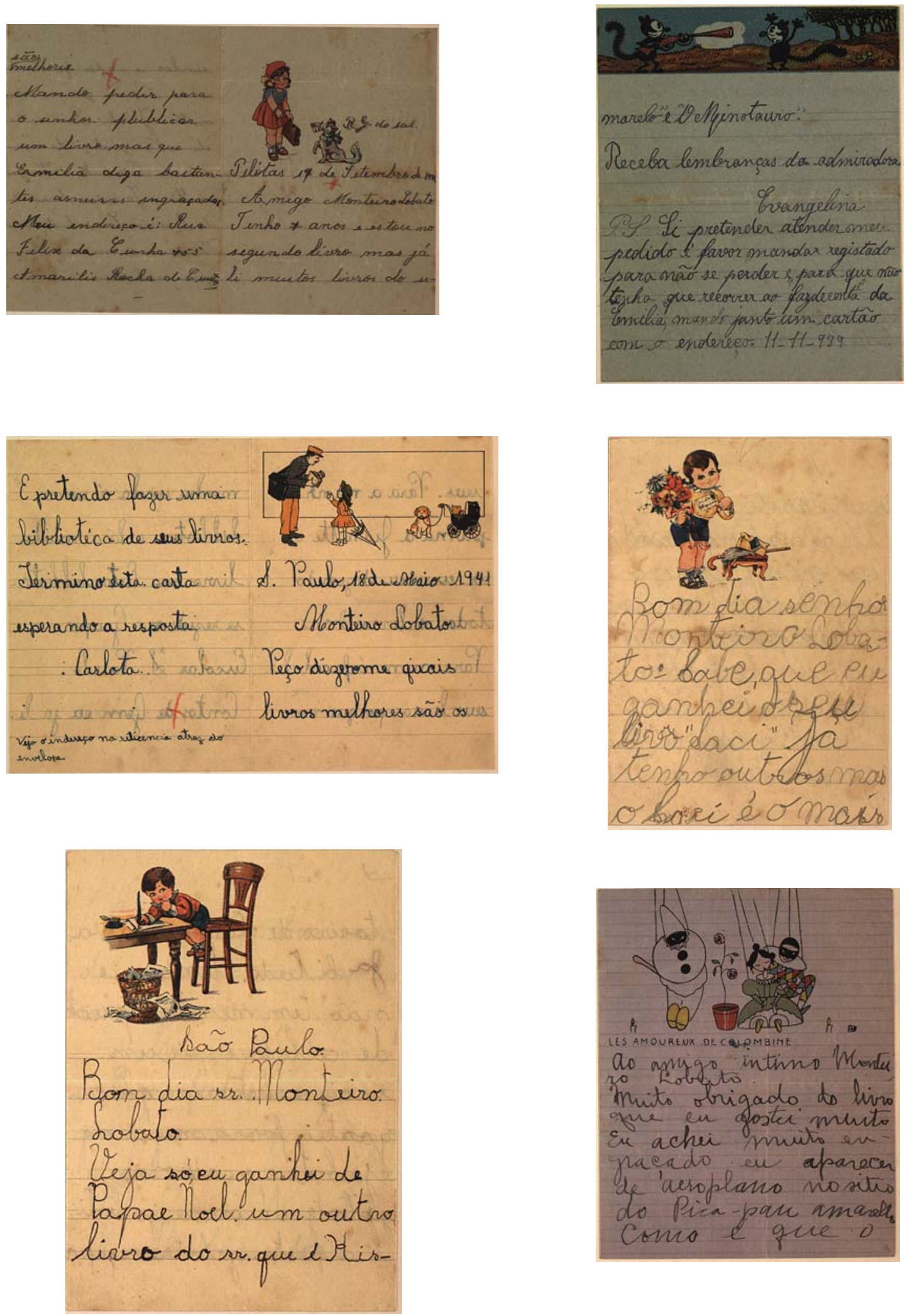
Podemos antever na reprodução dessas imagens uma determinada visão sobre o mundo da criança, ligada também ao desenho de histórias infantis ou mesmo dos quadrinhos. Esses papéis de cartas decorados nos mostram que a atividade epistolográfica não era algo restrito ao mundo adulto. Existia mesmo uma fabricação específica voltada ao público infantil que visava suprir de produtos materiais essa prática. Em uma das ilustrações vemos um menino sentado em uma cadeira visivelmente maior que a criança e ele debruçado na mesa tenta escrever a pena e tinta. A imagem parece indicar a precocidade da tentativa, pois o cesto está repleto de papéis com manchas e borrões. Não podemos esquecer que as canetas esferográficas só apareceram e se popularizaram décadas mais tarde. $\mathrm{O}$ aprendizado na escrita com penas ou canetas tinteiros era bastante penoso e, muitas vezes, resultava em cartas rasuradas, manchadas e com borrões, e para evitá-las era necessário passar a carta muitas vezes "a limpo”. Muitas cartas referem-se a essa dificuldade e, por vezes, pedem desculpas pelo uso do lápis ao invés da pena e tinta, pela caligrafia, ainda titubeante, ou então pelos inúmeros borrões existentes na correspondência:

“Não faça conta da letra porque tenho ainda 6 annos."

"Peço-lhe muitas desculpas por não escrever-lhe a tinta. Não tenho muita pratica e pode a letra sair borrada e feia.” ${ }^{\circ 1}$

Ou os utilizam como recurso:

"Desculpe-me os erros e borrões. Eles fazem parte da minha personalidade". ${ }^{82}$

Há cartas que são datilografadas, mas são minoria no conjunto total das correspondências. Contudo, quando o leitor opta por escrever a máquina frequentemente ele se refere no texto a essa opção, ou se desculpa por ainda não utilizar a máquina de forma eficiente:

"Peço desculpa pela simetria da carta é a primeira datilografia.”83

\footnotetext{
${ }^{80}$ Carta de Osmar. Sorocaba, 21/12/1937. IEB/ARAS. Cx 2 P 1 doc 5 .

${ }^{81}$ Carta de Breno Maciel. Recife, 04/07/1936. IEB/ARAS. Cx 1 P 1 doc 46.

${ }^{82}$ Carta de Modesto Marques. Tatuí, 12/12/1945 IEB/ARAS. Cx 1 P 2 doc 41.

${ }^{83}$ Carta de Haroldo Werneck Valle. Juiz de Fora, 14/05/1945. IEB/ARAS. Cx 4 P 2 doc 35.
} 
Já em cartas de leitores adultos se faz referência ao modelo de máquina utilizado, como no caso do médico residente no Ceará que se refere a uma máquina portátil, a Hermes Baby, a mesma que Lobato ajudou a vender em anúncio de jornais e revistas:

“(...)estou com a hermes baby em cima do joelho. “ 84

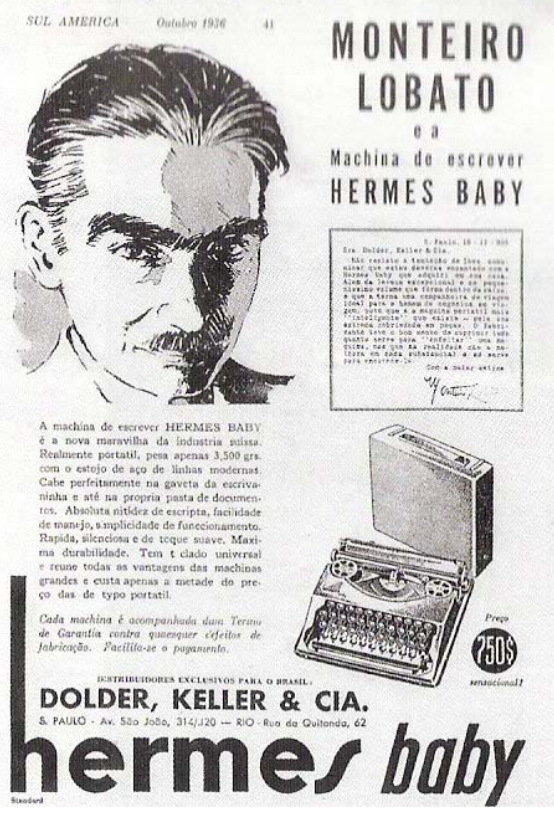

No entanto, a grande maioria das cartas é manuscrita e feita em papel sem decoração, com ou sem pauta, específicos para a correspondência ou não. Algumas cartas têm as iniciais gravadas, o que indica serem as crianças mais abastadas, e outras utilizam papel com o timbre do escritório do pai, propositadamente:

“Escrevo neste papel para o Snr. saber de quem sou filho."85

Há também quem utilize folhas bastante inapropriadas para a correspondência, como o leitor Celso Bentim, que faz uso de enormes tiras de papel, das que são usadas em caixas registradoras, para escrever uma comprida carta para Lobato. ${ }^{86}$

Em muitos casos os leitores escrevem também no verso do papel o que não deveria ser usual na época, pois escrevendo em papel fino, a tinta poderia aparecer no verso e dificultar a leitura. Mas alguns leitores explicam o porquê de utilizarem esse recurso em suas cartas:

\footnotetext{
${ }^{84}$ Carta de Quixadá Felício. Crato.CE. 05/08/1945. IEB/ARAS. Cx 4 P 2 doc 45.

${ }^{85}$ Carta de Breno Maciel. Recife, 04/07/1945, IEB/ARAS. Cx 1 P 1 doc 46.

${ }^{86}$ Carta de Celso Bentim. São Paulo, 20/11/1944. IEB/ARAS. Cx 4 P 2 doc 14.
} 
"Peço que me desculpe escrever no verso do papel, mas é que se eu tomar todas as vezes uma folha nova, o envelope não fecha...”87

Provavelmente era um costume do período utilizar papéis azulados para a correspondência, pois muitas cartas o faziam. Alguns leitores comentavam também essa prática:

"E peço desculpas pelo meu esquecimento na carta anterior. Disse tanta coisa e esqueci de mencionar minha idade, como fazem todas as meninas que escrevem em papel azul. Nem disse o dia em que escrevi, outra falha imperdoável para uma aluna do segundo ano ginasial...”88

Como as cartas chegavam até Lobato? Em muitas cartas percebe-se que a criança conseguiu o endereço de Lobato por meio de familiares ou amigos. Mas muitas cartas parecem ter sido endereçadas às editoras e livrarias que por sua vez a encaminhavam ao escritor. Uma das cartas enviadas, foi primeiro enviada a uma rádio carioca, a Rádio Globo, que veiculava "Reinações de Narizinho", para em seguida ir parar nas mãos de Lobato.

Em todo o acervo pesquisado somente alguns envelopes foram preservados, dentre eles um chama a atenção por sua peculiaridade: nele não havia a indicação de endereço. O leitor só havia escrito: “Ao Sr. Monteiro Lobato. Rio de Janeiro. São Paulo. Ou onde elle estiver.” E mesmo com tão poucas informações, a carta conseguiu chegar ao destinatário.

Na obra de Lobato temos também uma referência interessante sobre cartas e envelopes. Na obra Circo de Escavalinhos quando Pedrinho escreve convidando crianças amigas a participarem da festa no sítio, é assim que se refere ao envio das cartas:

"Quem levou as cartas? Quem mais se não esses preciosos portadores chamados envelopes? Mas como os senhores Envelopes não sabem chegar ao destino se não forem acompanhados dos senhores sobrescritos e de diversos senhores selos para acompanharem os senhores envelopes na longa viagem que tinham

\footnotetext{
${ }^{87}$ Carta de Alice D. von Trexler. Jaboticabal, ?/02/1945. IEB/ARAS. Cx 4 P 2 doc 36.

${ }^{88}$ Carta de Alice. São Paulo, 01/06/1945. IEB/ARAS. Cx 1 P 3 doc 30.
} 
de fazer. E esses portadores se comportaram muito bem. Nenhum se distraiu pelo caminho com brincadeiras, de modo que as cartas foram parar direitinhas nas mãos de cada um dos convidados”,89

\section{Escrevendo para Lobato}

Como já foi dito, as próprias crianças tinham consciência de que havia um modelo epistolográfico que deveria ser seguido, como datar e mencionar o local de onde se escrevia, mencionar a idade e algumas outras informações que identificassem o leitor, além da forma de tratamento utilizada para iniciar a carta. No início desta pesquisa, nos perguntávamos: como crianças de oito, nove ou dez anos poderiam escrever uma carta de forma tão sofisticada, pelo uso do vocabulário e também pelo modelo seguido? Naquele momento da pesquisa desconfiávamos da competência destes pequenos leitores e imaginávamos que eram auxiliados por seus pais e parentes próximos. Mas no decorrer do trabalho encontramos inúmeras gramáticas e livros de ensino da língua portuguesa do período, que ensinavam de que forma as cartas deveriam ser escritas. Por meio da pesquisa em livros didáticos percebemos que escrever cartas fazia parte do currículo desde os primeiros anos do grupo escolar, dessa forma compreendemos, em certa medida, como as cartas pesquisadas eram construídas. Como analisa Ângela de Castro Gomes, no Prefácio de Escrita de Si, Escrita da História:

“Cartas são assim, um tipo de escrita que tem fórmulas muito conhecidas, porque aprendidas, inclusive nas escolas, como a datação, o tratamento, as despedidas e a assinatura, além de um papel mais apropriado, um timbre/uma marca, um envelope, uma subscrição correta.(...),90

\footnotetext{
${ }^{89}$ MONTEIRO LOBATO. Circo de Escavalinhos. São Paulo: Cia Editora Nacional, 1929.

${ }^{90}$ GOMES, Ângela de Castro. Escrita de si, escrita da História: a título de prólogo. In: Escrita de Si, Escrita da História. Rio de Janeiro: Editora da FGV, 2004. p. 20
} 
Podemos também perceber o quanto as cartas eram usuais no cotidiano infantil por algumas propagandas veiculadas na revista O Tico-Tico. Em uma delas uma criança escreve a outra comentando como o Biotônico Infantil a tinha deixado forte. Mesmo sendo uma propaganda criada por um adulto para divulgar o referido biotônico, ela está veiculada em uma revista infantil, e para surtir o efeito desejado, a compra do biotônico, deve fazer parte do repertório do pequeno leitor, ele deve se identificar com a propaganda, para que solicite aos pais a compra do fortificante.

São inúmeras também as
cartas publicadas em vários
periódicos voltados ao público
infantil, praticamente todas as
revistas mencionadas no segundo
capítulo deste trabalho tinham
seções voltadas para a
correspondência recebida.

No contexto escolar, percebemos que nem sempre as cartas seguiam o roteiro aprendido pelo aluno. E por vezes na segunda missiva os leitores desculpavam-se tanto por erros estruturais como pelo

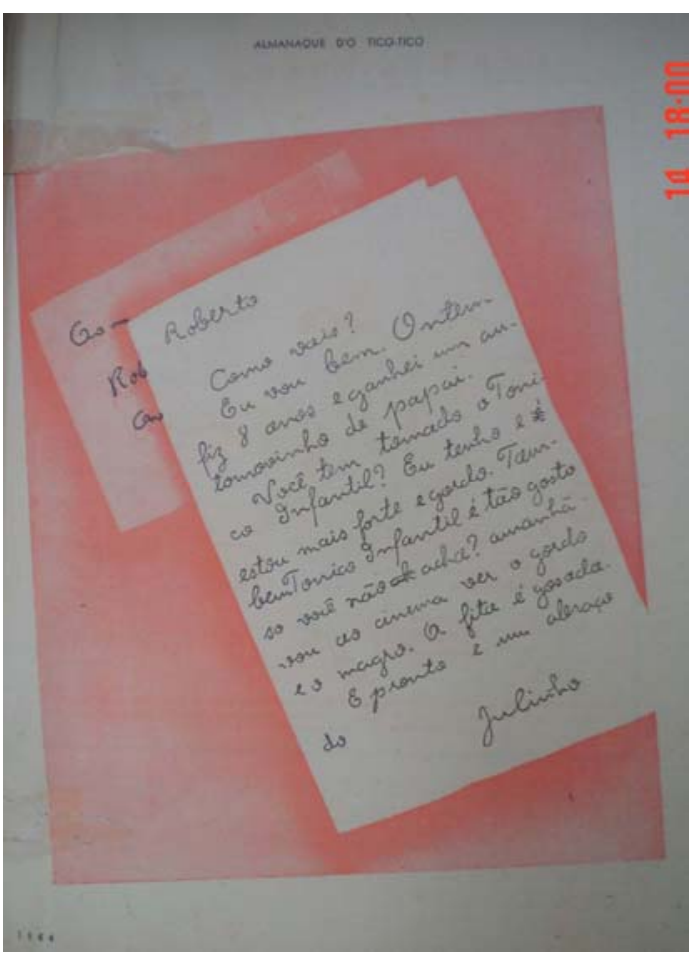

Propaganda no Almanaque do O Tico Tico, 1944. Seção de Bibliografia e Documentação. BML/PMSP. esquecimento de pontos importantes na confecção da carta.

Os comentários sobre erros cometidos por esquecimento e também ortográficos ou de acentuação são muito comuns nas cartas. Existem porém cartas com "erros” propositais, pois os leitores sabiam das divergências do autor sobre acentuação, nesse caso tais “erros” muitas vezes mostravam como o leitor gostaria de ser percebido pelo autor. No primeiro caso os erros podem indicar a precocidade da escrita, e que ainda não dominam inteiramente o código escrito, ou pela pouca idade ou pela pouca escolarização. A escrita era ainda mais difícil para os jovens leitores, pois 
durante o período estudado foram muitas as modificações ortográficas e de acentuação, fato esse comentado nas cartas.

"Não vá contar os erros que tenho nesta carta leia-la como se estivesse direita, ainda sou muito criança para saber muita coisa”91

“Espero que o senhor há de perdoar os meus erros pois ainda sou fraca no português"92

“(...) desculpe os inúmeros erros porém é errando que se aprende."93

“(...) gostaria de saber escrever. Não para os jornais, que dizem todas as coisas erradas mas para poder escrever sem erros e sem falhas, para quem escreve tão bem, sabe quem é?”94

Muitas vezes, o medo dos erros que iriam cometer desestimulava a escrita das cartas. Como no caso da menina Alice, que observava:

"Sempre tive vontade de escrever ao Sr. mas fico pensando nos erros que vou cometer e acabo desistindo. Hoje afinal resolvi-me e estou escrevendo.”95

Já no trecho transcrito abaixo vemos como muitos leitores conheciam a opinião de Lobato sobre a acentuação excessiva de nossa língua e, no caso específico deste leitor, comemoram com o escritor, chamando-o de “prevedor” das reformas ortográficas. É interessante também notar a divergência mencionada entre a opinião de Monteiro Lobato e a do professor de português, considerado pelo menino "um velho arcaico":

"Prezado sr:

Venho , por meio desta, congratular-me com o Dr. Monteiro Lobato, o ‘insubmisso'. Saiu hoje, no 'Diário Popular', parte do acordo ortográfico assinado em Portugal. Por ali vemos que o trema (") foi eliminado e o numero de acentos, que era imenso, reduzido.

\footnotetext{
${ }^{91}$ Carta de Gilson Maurity Santos. Rio de Janeiro, 28/04/1934. IEB/ARAS. Cx 1 P 1 doc 7.

${ }_{92}$ Carta de Maria Josefina. Curitiba, 28/10/1936. IEB/ARAS. Cx 1 P1 doc 50.

93 Carta de Edith Canto. Botucatu, 12/12/1939. IEB/ARAS. Cx 1 P 2 doc 15.

${ }^{94}$ Carta de Alice. São Paulo, 01/06/1945. IEB/ARAS. Cx 1 P 3 doc 30.

${ }^{95}$ Carta de Wanda Cortes. Juiz de Fora, 22/02/1945. IEB/ARAS. Cx 1 P 3 doc 26.
} 
O sr, pelo que parece, é um tanto ou quanto 'prevedor' (vocábulo instituído tão somente para o sr.). Escrevia pelo atual método enquanto que, os outros, pelo método “complicado”. Não acentuava quasi nenhum vocábulo, e vem hoje um acordo provar-me que a razão estava, como sempre, consigo.

Constatando mais uma vez de fato o senhor é quase infalível, foi que me animei a, novamente, importuna-lo.

Nosso professor de português - um velho 'arcaico' - detesta-o. Diz ele que o senhor é muito revolucionário e que quer 'deturpar’ a língua com seus métodos de simplificação. Vou contar-lhe exatamente o que sucedeu.

Estava ele - o professor de português, que é luso - contando que Gonçalves Viana, em Portugal, não havia aceitado a ortografia imposta pelos ‘alhos gramaticais’, (desculpe-me o plágio) que o senhor também recusou seguir.

Eu não me contendo, disse ao meu professor que o senhor não havia também aceitado. Então foi que ele disse o que está escrito encima. $(\ldots)) 96$

Sobre a não utilização de acentos vemos que outras cartas também comentam o fato, por vezes, até se desculpando por utilizá-los. Do mesmo leitor temos o trecho transcrito abaixo, na carta seguinte a Lobato:

"Eu espero, Dr. Lobato, que o senhor me perdoe esses acentos mas, se estão ai, é porque acostumei-me a eles. Espero que o senhor se recorde de que sou estudante portanto tenho que obedecer ao professor de português ou levarei 'bomba'...”97

Comentário parecido temos na carta do jovem Celso Bentim, o qual, de forma inusitada, revela-se constrangido por seguir as regras:

“Aproveito o ensejo para pedir desculpas de estar saindo, as palavras, quase todas acentuadas. No ginásio foi obrigatório. Brigar com o professor significa reprovação, infelizmente o habito fez-me assim, seria, creio eu, agora infantilidade minha tirar ou riscar todos

\footnotetext{
${ }^{96}$ Carta de Carlos Alceu C. Junqueira. São Paulo, 08/11/1945. IEB/ARAS. Cx 1 P 3 doc 36.

${ }^{97}$ Carta de Carlos Alceu C. Junqueira. São Paulo, 19/11/1945. IEB/ARAS. Cx 1 P 3 doc 37.
} 
os acentos. Espero não ter sido esse o motivo da não resposta de três ou quatro cartas que escrevi antes desta e confiando menos no correio que na atenção do amigo, foi que agora passo a redigir a minha quinta carta." 98

Ainda sobre as reformas feitas na língua portuguesa, encontramos críticas que ultrapassam, em muito, questões ligadas a ortografia, quase como se o leitor compartilhasse com o escritor a insatisfação com a realidade do país:

"Pena que eu não sei escrever como o senhor, porque tenho muita conta a ajustar (isso é mais ou menos sentido figurado!) com muita gente lá do alto, que me deixa meio maluca com leis de ensino, regras e reformas na acentuação e ortografia das palavras (gostaria muito de conhecer o Capanema, para pisar no seu calo predileto, desforando-me das mexidas que ele faz) e muita coisa mais."

“Aliás, muita coisa mesmo anda precisada de reforma, não acha? Mas só quem as sofre é a Ortografia....”100

Nessa carta fica evidente que apesar de possuírem um modelo a ser seguido, que era ensinado nas escolas, os leitores possuíam a liberdade de escrever as cartas de forma mais espontânea. E a espontaneidade muitas vezes está relacionada a aproximação da escrita da carta com a oralidade. Assim, o que vemos é quase que um sucedâneo da fala. Talvez na correspondência com Lobato essa forma mais livre pudesse aparecer, pois tanto nas poucas respostas de Lobato aos leitores como em suas obras literárias a oralidade e a irreverência aparecem com bastante ênfase. Dessa forma a escrita das cartas se aproxima e se baseia no padrão lido pelas crianças.

Podemos notar também que os leitores percebem a relação direta entre leitura e escrita, e como a leitura faz com que aprendam a escrever melhor. Desta forma se aproximam do que Mário Quintana, relembrando os tempos de menino, nos relata:

\footnotetext{
${ }^{98}$ Carta de Celso Bentim. Curitiba, 05/03/1945. IEB/ARAS. Cx 4 P 2 doc 15.

${ }^{99}$ Carta de Alice D. von Trexler. Jaboticabal, ?/02/1945. IEB/ARAS. Cx 4 P 2 doc 36.

${ }^{100}$ Carta de Sandra Martins Cavalcanti. Rio de Janeiro, 25/06/1944. IEB/ARAS. Cx 4 P 2 doc 21.
} 
"Sim, havia aulas de leitura naquele tempo. A classe toda abria o livro na página indicada, o primeiro da fila começava a ler e, quando o professor dizia 'adiante', ai do que estivesse distraído, sem atinar o local do texto! Essa leitura atenta e compulsória seguia assim banco por banco, do princípio ao fim da turma.

E como a gente aprende a escrever lendo, da mesma forma que aprende a falar ouvindo, o resultado era que - quando necessário escrever um bilhete, uma carta - nós, os meninos, o fazíamos naturalmente, ao contrário de muito barbadão de hoje.(...) $)^{\text {101 }}$

Como vemos Mário Quintana também se refere à escrita de cartas como algo usual, feito com facilidade, resultado, na sua opinião de leituras exaustivas feitas na própria sala de aula, oralmente.

Com a mesma percepção a menina Marjori escreve a Lobato para incentivá-lo a publicar “A Barca de Gleyre”. Pela carta percebemos que ela teve contato pessoal com o escritor, provavelmente através do amigo comum mencionado na carta, Moacyr, e que não teve coragem de fazer pessoalmente um pedido bastante especial:

“Gostei mesmo demais das cartas do sr. que o seu Moacyr me deu pr’a ler e fiquei tão entusiasmada do sr. publicá-las! O sr. não se importa com o que eu digo, mas essas cartas vão nos ensinar, a todos nós pirralhos a escrever quando crescermos e aparecermos.

Não seja ingrato, seu Moacyr disse que o sr. estava procurando saber se elas eram de fato boas para publicar. Porque duvida quando sabe que é mesmo um colosso?

Vou lhe pedir uma cousa que não pude na sua frente porque fiquei com muita vergonha: quer dizer nelas que eu, uma sua leitorinha que conhece todos os seus livros de cor e adora a Emilia, insistiu para o sr. publicar as cartas? Vai pôr o meu nome? Oh, que bom!

${ }^{101}$ QUINTANA, Mário. A vaca e o hipogrifo. São Paulo: Globo, 1995. p. 112. 
Dr. Lobato, eu não sei escrever, mas eu sei muito bem o que é bonito, sabe?” (...)

“De medo do sr. não publicar o livro, até copiei algumas quando o sr. Moacyr me emprestou. Aquela do Bode, também, achei um doce.

Se quizer me fazer esse grande favor eu lhe ficarei adorando, como adoro a Emilia, que desconfio que é o sr. mesmo, em carne e osso, disfarçado, em bruxinha de pano.

Se eu tiver essa felicidade vou ficar toda a vaidosa e vou mostrar o livro a todas as minhas coleguinhas que vão se morder de inveja de mim."102

A citação é longa, mas mostra a importância dada pela leitora às cartas de Lobato a Rangel, lidas antes mesmo da publicação. Percebemos assim que o universo de leituras das crianças leitoras não se restringia somente às obras infantis de Lobato, como veremos a seguir. A carta de Marjori revela, também, uma postura bastante freqüente no universo das cartas: a solicitação para serem mencionados em livros ou para aparecerem como personagens nas aventuras de Pedrinho, Narizinho e Emília. Ao mesmo tempo vemos claramente uma postura bastante sincera ao expor o quanto ficaria vaidosa e seria invejada pelas amiguinhas, afinal de contas se receber uma carta de Lobato já era considerado pelas crianças um grande presente, imaginem, então, ter o nome mencionado em uma obra. Como sempre o escritor cede aos pedidos da leitora e coloca seu nome, na dedicatória da Barca de Gleyre, entre os de sua esposa Purezinha e do saudoso amigo Ricardo Gonçalves:

“Três nomes... Nesta casca de árvore quero escrever três nomes: o de Purezinha, a Mater Dolorosa com a qual vou descendo o morro, de mãos dadas e saudades em comum; o de Marjori, a criaturinha que simboliza todas as que se lembram de mim e me escrevem; e qual seria o terceiro, se não o de Ricardo, o Inesquecível?”103

\footnotetext{
${ }^{102}$ Carta de Marjori Sundart. São Paulo, 25/05/1944. IEB/ARAS. Cx 2 P 1 doc 29.

${ }^{103}$ LOBATO, Monteiro. Barca de Gleyre: quarenta anos de correspondência literária entre Monteiro Lobato e Godofredo Rangel. 8.ed. São Paulo: Ed. Brasiliense, 1957. tomo I. P. 16.
} 


\section{A escrita de si}

Em grande parte da correspondência percebemos essa transparência com relação ao autor, muitas vezes até mesmo quando falam de si, como na carta de Marjori. Entretanto, em alguns trechos vemos que as crianças também fazem através da escrita das cartas uma escrita de si, assim como na documentação adulta.

Uma das características mais comentadas nas cartas é a da idade dos leitores, alguns comentam que são ainda muito crianças, enquanto outros dizem:

“(...) pois não sou mais muito criança”104

“Mas, Monteiro Lobato, está acontecendo comigo o que Narizinho, Pedrinho tem horror: virar gente grande, infelizmente não posso ser como Peter Pan, já fiz em fevereiro, 15 anos(...)”105

Quando os leitores comentam serem ainda muito novos, esse comentário está sempre justificando um saber ainda não adquirido. Não conseguem escrever de forma adequada utilizando a pena e tinta ou às vezes não conseguem ler aquilo que gostariam das obras de Lobato, como Liliana, neta de Alfonsus Guimaraens:

“(...)os outros [livros] tem muita ciência e eu não entendo pois fiz 9 anos dia 18 de junho.»106

Ou, como Gilson, se enganam e compram um livro para o público adulto e não conseguem prosseguir na leitura:

“Só um ano saiu um livro que me enganou - O escândalo do Petróleo.

- Oh delicia! Murmurava eu no bonde, apertando o livro contra o peito com os dois braços com se tivesse que protege-lo do mundo. A imaginação dava saltos, cambalhotas, a fantasiar quem de novo lá aparecia, que fariam os meus velhos amigos do sitio. Tive de fazer uma força enorme para não abrir o pacote ali mesmo no bonde. Consegui. Não abri.

\footnotetext{
${ }^{104}$ Carta de Modesto Marques. Tatuí, 10/12/1945. IEB/ARAS. Cx 1 P 2 doc 40.

${ }^{105}$ Carta de Nice Viegas. Niterói, 29/05/1942. IEB/ARAS. Cx 1 P 2 doc 26.

${ }^{106}$ Carta de Liliana Guimaraens. Belo Horizonte, 23/06/1942. IEB/ARAS. Cx 1 P 2 doc 48.
} 
Só em casa comecei a ler. Poucas paginas bastaram para me mudar as idéias.

- 'Mas', disse consigo mesmo, 'não faz mal. Estou ficando moço e preciso ler coisas sérias. E, demais, o livro é do Lobato.'

Devo dizer que as dez paginas seguintes me fizeram tropeçar e fechar o livro entristecido. Não compreendia nada.”107

Mas da mesma forma que comentam com Lobato seu insucesso na leitura devido a pouca idade, comentam também os sucessos, principalmente, na escola. Como a menina Cordélia de Belo Horizonte, que estando na quarta série ginasial, nos diz:

“Como terminei minhas provas parciais no sábado, e fiquei mais

'folgada', resolvi escrever-lhe.

Fui muito bem nas provas; até agora só o resultado da de inglês, e por sinal tirei o primeiro lugar na classe. (Mas não vá me responder esta carta, em inglês)"108

A mesma menina um ano depois, em novembro de 1945, comenta:

“Recebi ontem o meu diploma de 'Professora de Música'.

Obtive as maiores notas anuais nos curso de Pedagogia, Ciências e História da Música. Quando lhe escrevi, há dias, só sabia do resultado do Curso de Pedagogia.”109

Ou ainda a carta de Severino, que tem nove anos e pretende continuar mantendo os bons resultados:

“Eu já estou, em férias, passei para o $5^{\circ}$ ano primário com boas notas e espero fazer o $5^{\circ}$ ano ainda com melhores notas.”110

\footnotetext{
${ }^{107}$ Carta de Gilson Maurity Santos. Rio de Janeiro, sem data, provavelmente de março de 1943. IEB/ARAS. Cx 4 P 2 doc 53.

${ }^{108}$ Carta de Cordélia Fontainha Seta. Belo Horizonte, 30/10/1944. IEB/ARAS. Cx 1 P 3 doc 5.

${ }^{109}$ Carta de Cordélia Fontainha Seta. Belo Horizonte, 28/11/1945. IEB/ARAS. Cx 1 P 3 doc 9.

${ }^{110}$ Carta de Severino de Moura Carneiro Junior. Rio de Janeiro, 29/12/1945. IEB/ARAS. Cx 1 P 3 doc 25.
} 
Já o menino Gilbert, de doze anos relata seu sucesso e também de seus irmãos:

“ (...) Eu já entrei em ferias e agora sou quarto anista.

Meus irmãos também passaram nos seus exames.”111

Em muitas cartas percebe-se o cotidiano das crianças, comentado por elas mesmas, em algumas existe a preocupação em mostrar o quanto são estudiosas e seu desempenho na escola. Mas também percebemos que as crianças tinham inúmeras atividades, nas quais a escola não tinha um papel preponderante, muitas comentam cursos de música, principalmente os Conservatórios para o estudo de piano, ou esportes praticados fora do contexto escolar. Todas essas atividades, na opinião das crianças, muitas vezes impediam que escrevessem com mais freqüência. Como Gilson, que lamenta não ter tempo para treinar boxe e também para escrever para seu escritor favorito, pois as provas e o estudo de piano tinham que vir em primeiro lugar:

“Caro amigo Monteiro Lobato:

Estou até com vergonha de escrever-lhe esta carta.

Você me desculpe mas, quando recebi sua carta, ia responder mas calhou de chegar minhas provas parciais começarem. Tinha muito que estudar. Depois os dias passaram-se muito depressa; minha mãe ocupou muito meu tempo fazendo-me estudar piano quando chegava do collegio."

Ou Evangelina, que parece estar com a consciência um pouco pesada de se divertir lendo os livros de Lobato ao invés de estudar:

"Vou acabar, pois, o estudo preciza ser olhado, já que foi um pouco abandonado com a chegada de dois visitantes tão interessantes. “O Picapau Amarelo” e “O Minotauro”. 113

Já Marila Gravenstein Borges fala de si com bastante confiança, e apesar de sua idade, doze anos, já está no oitavo ano de piano, do

${ }^{111}$ Carta de Gilbert Hime Jr. São Paulo, 08/12/1939. IEB/ARAS. Cx 1 P 1 doc 35.

${ }^{112}$ Carta de Gilson Maurity Santos. Rio de Janeiro, 14/07/1934. IEB/ARAS. Cx 1 P 1 doc 8.

${ }^{113}$ Carta de Evangelina. Fazenda Sto. Inácio, 11/11/1939. IEB/ARAS. Cx 2 P 1 doc 7. 
Conservatório Dramático e Musical, convida o autor para ouvi-la nas rádios da cidade:

“Tenho doze annos de idade, gosto muitíssimo de música, sou aluna do Conservatório Dramático e Musical, aonde freqüento o oitavo anno.

Dizem que tenho vocação para o piano.

O senhor poderá fazer o seu juízo ouvindo-me

Toco pelas nossas estações de Rádio.

Haverá no sítio de D. Benta, logar para uma pequena pianista?

Quem sabe...”114

A carta de Marila nos mostra que muitas vezes as crianças tinham uma participação social que em um primeiro momento não imaginávamos. Como na menção ao fato de ela tocar nas rádios paulistanas. Outra leitora mencionada no início deste capítulo, Wanda Côrtes pede auxílio, pois necessita passar em um concurso para auxiliar os pais:

“Eu quero que Sr. faça o obséquio de pedir à D. Benta que me ensine mais alguma coisa de Português além do que ela ensinou no livro.

Digo já porque. É porque eu quero inscrever-me num concurso e quase não sei Português.

Se ela pudesse fazer-me esse obséquio eu ficaria tão satisfeita!

Tenho uma gramática mas infelizmente leio, leio e não entendo nada.

Preciso muito passar neste concurso pois Papai está desempregado (faz carretos quando têm) e eu ganho uma ninharia onde trabalho.”115

O fato de muitos leitores possuírem somente a escolarização primária era reflexo de uma escassez de ginásios para a continuação do ensino. Apesar do número de matrículas escolares terem crescido nas décadas de 30 e 40, havia um número muito grande de desistências e reprovações, o que fazia com que fosse pequeno o número de crianças

\footnotetext{
${ }^{114}$ Carta de Marila Gravenstein Borges. São Paulo, sem data, provavelmente 1932. IEB/ARAS. Cx 1 $\mathrm{P} 1$ doc 2.

${ }^{115}$ Carta de Wanda Côrtes. Juiz de Fora, 22/02/1945. IEB/ARAS. Cx 1 P 3 doc 26
} 
e jovens que pudessem terminar os estudos. Mesmo na década de 40, o número de analfabetos era de 56,2\% da população com mais de 15 anos, e apenas $21 \%$ das crianças e jovens com idade de 5 a 19 anos

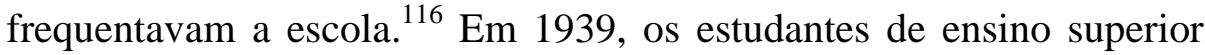
em todo o país não passavam de 21.235. ${ }^{117}$ Assim sendo, o ensino superior era então um sonho muito mais distante, como mostra a carta da leitora Alice:

“(...) eu acabei o científico (...) ganho a vida dando aulas particulares a alunos atrazados, porque estudo superior no Brasil está fora do alcance da maioria dos estudantes. Nós não somos nada, pelo menos, ainda não somos nada para poder ajudar homens de boa vontade como o senhor. Olhe 'seu’ Lobato, gente honesta, de bons propósitos, no meio de tanto cafageste rico e poderoso, repimpado no governo é 'fosque pagado!',"118

A preocupação com o trabalho é bastante freqüente nas cartas de jovens leitores, muitos falam de dificuldades para prosseguirem os estudos, como no caso de Alice e também comentam oportunidades de trabalho por meio de concursos, como Wanda. Em algumas cartas percebemos que alguns leitores vinham de estratos bastante humildes da população, como nas cartas do jovem Ari Reginaldo Soares, que começa a se corresponder com Lobato em 1943, quando tinha dezesseis anos, e ainda residia na cidade de Gália, interior de São Paulo. O arquivo pesquisado preserva dez cartas deste leitor, nessas cartas podemos perceber um pouco da trajetória deste jovem, suas aspirações, suas leituras e também algumas reflexões sobre si mesmo. A primeira carta é provavelmente anterior a outubro de 1943, pois não está datada, comenta algumas obras de Lobato. Inicia a missiva dizendo estar contente devido a inclusão de um conto de Lobato no livro As obras Primas do Conto Brasileiro, comenta que espera que o conto escolhido seja “O colocador de Pronomes", pois segundo o leitor "nesse conto o senhor tem uma distinção, um certo que, que não posso exprimir”. Compara o conto

\footnotetext{
${ }^{116}$ SOARES, Gabriela Pellegrino. Semear Horizontes. Belo Horizonte: Ed. UFMG, 2007. p. 53-54.

${ }^{117}$ FAUSTO, Boris. História do Brasil. São Paulo: Edusp, 2001. p. 394.

${ }^{118}$ Carta de Alice von Trexler. Jaboticabal, ?/02/1945. IEB/ARAS. Cx 4 P 2 doc 36.
} 
“O Jardineiro Timotheo” com as obras de Katherine Mansfield, que diz ter apreciado nas "Novelas" da Globo. Em seguida comenta as obras infantis e também obras da coleção adulta:

"Leio os seus livros desde os sete anos: Reinações de Narizinho, Narizinho Arrebitado? Noivado de Narizinho e outros tantos que não convem menciona-los para não massal-o mais do que está.

Professor, (admira-se? Pois não devia quem escreveu História do Mundo para as crianças, Aritmética da Emilia e a mesma no Paiz da Gramática..) se não leio Peter Pan, Caçadas de Pedrinho, O marquês de Rabicó é somente para não relelos pela quarta ou quinta vez e também porque não os tenho, mais nas horas vagas, dou um pulinho ao Grupo Escolar e leio: Fábulas, Minotauro e o que é mais: Reforma da Natureza e Espanto das Gentes. Há poucos dias li: No mundo da lua, Negrinha e Ideas de Jeca Tatu. Pelos mesmos constatei que o senhor há 20 anos foi editor.”

Neste trecho vemos - como ocorre em quase todas as cartas endereçadas a Lobato pelos leitores - uma quantidade enorme de informações sobre a leitura, todas elas entrelaçadas. Em primeiro lugar, Ari revela ter iniciado a leitura dos livros infantis aos sete anos, esse fato também é percebido em inúmeras cartas que mostram que logo que aprendiam a ler as crianças mergulhavam no universo criado pelo escritor. Em seguida chama Monteiro Lobato de "professor", essa relação estabelecida pelos leitores, também é freqüente, muitos julgam-se seus “alunos" ou mesmo seus “filhos”, deixando claramente enunciado a afetividade que nutriam pelo escritor. Contudo, esse trecho da carta de Ari R. Soares nos mostra ainda dois dados, um, também bastante repetido nas cartas, que revela que a leitura das obras de Lobato era intensiva, os leitores se referem constantemente a lerem inúmeras vezes o mesmo livro. Para uma determinada classe social, em determinadas regiões do país deveria ser difícil o acesso aos livros, devido principalmente a falta de bibliotecas públicas. No entanto, vemos que o leitor dribla essa falta, pois menciona uma informação que é única em toda a correspondência: a utilização da biblioteca do Grupo Escolar, por um jovem que já não era mais aluno da instituição. Por aparecer uma única vez em todo o corpo documental não podemos imaginar que a utilização de 
bibliotecas de Grupos Escolares fosse uma prática freqüente, no período. Contudo, no caso deste leitor em especial e, talvez, em virtude da escassez de recursos da família, a utilização da biblioteca escolar provavelmente era a única alternativa para a leitura deste jovem. Aliás, as referências às bibliotecas escolares são sempre no sentido de comentarem o quanto elas estão desfalcadas, e por isso os alunos pedem a Lobato que enviem alguns livros como presentes. Cartas como a do aluno Mário Granato:

“S. Paulo, 24 de Agosto de 1935.

Ilmo Sr. Monteiro Lobato.

Neste Grupo Escolar 'Marechal Deodoro’, existe uma biblioteca infantil, para uso dos alunos; mas, na ultima revolução, tendo sido o predio ocupado pelos soldados, a nossa biblioteca quasi, desapareceu. Em nome, pois, do meu Grupo venho pedir ao Sr., o favor de nos dar uns livros seus, cuja leitura é por nós muito apreciada.

Desde já muito lhe agradece, e em nome dos colegas.

o amiguinho e admirador

Mario Granato.”119

Ou como a carta enviada pelos alunos de um Grupo Escolar da cidade de Dores do Indaiá, Minas Gerais:

“Dores do Indaiá, 14 Abril 1944.

Sr. Monteiro Lobato,

Não pode calcular nossa satisfação em escrever para o autor de tantos livros bons, de tantas histórias bonitas que estão espalhadas neste Brasil inteiro, dando tanta alegria a nós brasileirinhos.

Há muito tempo era nosso desejo mandar-lhe uma cartinha, pois os seus livros são os mais apreciados em nosso Grupo Escolar.

Já conhecemos alguns e temos grande vontade de conhecer mais outros, mais algumas destas historias que só o senhor sabe escrever, mas a nossa biblioteca é tão pobre... Por isso vimos fazerlhe um pedido na certeza de que não será em vão: - presentear-nos

${ }^{119}$ Carta de Mário Granato. São Paulo, 24/08/1935. IEB/ARAS. Cx 1 P 1 doc 29. 
com alguns de seus livros. Só assim nossa biblioteca ficará mais interessante e a visitaremos com mais prazer.

Sabendo que muito breve o senhor vai nos mandar o belo presente, agradecemos-lhe com um forte abraço de simpatia.

Alunos do $3^{\circ}$ ano 'Cr 1-2' do Grupo Escolar 'Dr Zacarias'

Dores do Indaiá, oeste de Minas Gerais»"120

Ou ainda a carta da jovem Alice, de Jaboticabal, comentando o encontro com o livro O Escândalo do Petróleo na biblioteca escolar:

“O último livro que li, de sua autoria, foi ' $O$ escândalo do petróleo’.

Meu colega de escola, o primeiro da classe e talvêz do colégio todo, é um filho de japonês: Matinas. É, como eu, um fervoroso admirador seu; sempre mexemos na biblioteca desfalcada, lendo tudo. Um dia encontramos seu livro, atráz de uns volumes de geografia, meio abandonado.”121

Além da carta de Ari Reginaldo Soares, existe uma única carta em todo o conjunto de correspondência guardada que tece um comentário positivo sobre a biblioteca da escola:

“S. Paulo, 18 de Maio 1941

Monteiro Lobato

Peço dizer-me quais livros melhores são os seus. Para a minha prima Jeanette o sr. escreveu dizendo todos os livros bons.

Para mim é fácil ler seus livros porque na minha escola á uma

biblioteca e lá á muitos livros seus. Esta biblioteca se rezide no

Grupo Escolar 'S. Paulo’.

Contos de Grimm eu já li.

E pretendo fazer uma biblioteca de seus livros.”122

No entanto, pela carta de Carlota percebemos que ela provavelmente ainda não freqüentava assiduamente a Biblioteca, pois diz ter lido Contos de

\footnotetext{
${ }^{120}$ Carta dos alunos do $3^{\circ}$ ano do Grupo Escolar Dr. Zacarias. Dores do Indaiá. MG, 14/04/1944. IEB/ARAS. Cx 2 P 1 doc 28.

${ }^{121}$ Carta de Alice von Trexler. Jaboticabal, ?/02/1945. IEB/ARAS. Cx 4 P 2 doc 36.

${ }^{122}$ Carta de Carlota. São Paulo, 18/05/1941 IEB/ARAS. Cx 2 P 1 doc 8.
} 
Grimm, provavelmente em tradução de Lobato, mas deseja saber quais são os melhores livros do autor para iniciar sua leitura. A diferença entre Carlota e Ari é bastante grande, provavelmente Carlota é ainda uma criança com menos de dez anos, parece não ser ainda uma leitora habitual. Pela correspondência percebemos que ela pretende montar sua própria biblioteca, isto é deseja comprar os livros de Lobato. O próprio papel no qual escreve indica pertencer a uma família, se não abastada, com meios de comprar artigos específicos, como papéis de carta decorados.

Já Ari é um “modesto estafeta” como ele próprio nos conta:

“O senhor julga que eu queira ostentar um saber que não possuo? Engana-se, eu sou bastante inculto e sei-o (a minha carta testemunha isso) só tenho o modesto diploma do $4^{\circ}$ ano primário, não por falta de vontade mas sim pela de ... Sou um modesto estafeta (que diz? Sobre um buro não...) mais isso não pode nem deve impedir que eu deseje subir.” 123

As cartas nos mostram que em abril de 1944, o leitor se muda para São Paulo, provavelmente em busca de melhores oportunidades de trabalho, como ainda não fez dezoito anos necessita de autorização especial para poder trabalhar. Relata na carta a Lobato a situação social de quem como ele necessita trabalhar sendo ainda menor de idade:

“(...) o senhor talvez raramente saia do centro da cidade ou do Jardim Paulista, só vendo para crer, menores e mais menores nos Centros de Saúde e no Palácio das Indústrias dormem ao relento para tirar os papéis para trabalhar, tal não aconteceu comigo mas eu tomei chuva na fila sem sair do lugar e ensopado não sei porque pensei em condutores de homens."124

O leitor consegue, pouco tempo depois, o emprego de polidor de torneiras na Fundição Brasil, na Mooca. Escreve para Lobato contando as dificuldades dos primeiros meses:

"Minha mocidade e infância não são românticas como a sua que assemelha-se a do Eça de Queiroz, veja-se as ‘farpas’ e o ‘Minarete’;

\footnotetext{
${ }^{123}$ Carta de Ari Reginaldo Soares. Gália. SP. Sem data, provavelmente anterior a outubro de 1943. IEB/ARAS. Cx 4 P 2 doc 9

${ }^{124}$ Carta de Ari Reginaldo Soares. São Paulo, 18/04/1944. IEB/ARAS. CX 4 P 2 doc 4.
} 
talvez por culpa minha ainda não conheço Spinoza e não sei francez...

Agora que tudo passou e mesmo que queira ajudar-me não poderá (pois que já passou) dir-lhe-ei: em Dezembro quando fui visita-lo morava em uma construção por favor, fazia eu mesmo a comida, quantas espécies de comidas não comi até aprender... Si viesse a produzir algo em literatura não sei o que sairia. (...)”125

Aqui vemos que, muitas vezes, as cartas eram usadas como substitutos da oralidade. Fatos e sentimentos que não eram passíveis de serem verbalizados encontravam guarida e chegavam até o destinatário por meio do escrito. Em muitas cartas enviadas a Lobato, principalmente por jovens, notamos a necessidade que alguns tinham de encontrar com quem pudessem conversar, um amigo a quem pudessem contar segredos, por vezes muito íntimos. Dessa forma as cartas atuavam de forma catártica, cumpriam seu papel amenizando aflições e recalques, só possíveis de serem expressos por meio do papel. Ângela de Castro Gomes assim analisa a importância da correspondência:

“A escrita epistolar é, portanto, uma prática eminentemente relacional e, no caso das cartas pessoais, um espaço de sociabilidade privilegiado para o estreitamento de vínculos ente indivíduos e grupos.

(...) A escrita de si e também a escrita epistolar podem ser (e são com freqüência) entendidas como um ato terapêutico, catártico, para quem escreve e para quem lê. $\mathrm{O}$ ato de escrever para si e para os outros atenua as angústias da solidão (...)”126

As cartas que crianças e, principalmente, jovens escreveram para Lobato podem ser analisadas por essa perspectiva, mas como veremos a seguir a correspondência que por vezes se estendia por anos também possibilitava aos leitores a um contato pessoal com o escritor.

\footnotetext{
${ }^{125}$ Carta de Ari Reginaldo Soares. São Paulo, 10/05/1945. IEB/ARAS. Cx 4 P 2 doc 8.

${ }^{126}$ GOMES, Ângela Castro (org.) Escrita de Si, Escrita da História. Rio de Janeiro: Ed. FGV, 2004. p. $19-20$.
} 


\section{Encontros com Lobato}

Na terceira carta escrita por Ari Reginaldo Soares a Monteiro Lobato, um comentário a respeito de si, revela o preconceito racial introjetado:

“(...)Escute caro mestre, o senhor acha que si eu fosse um pretinho beiçudo, cabelos carapinhado pernóstico como todo eles são, poderia gostar de mim a mesma coisa, do mesmo modo, sem distinção? Todos dizem que os pretos são iguais isto é ‘sujos' mas não creio que isso impeça haja alguns diferentes.”127

Não temos a resposta de Lobato, mas pelas cartas escritas na seqüência percebemos que quando se muda para São Paulo o leitor visita Lobato, no mínimo três vezes, e é assim que relata suas visitas à casa do escritor:

“(...)O homem, tem a verdade á frente do nariz mas não a enxerga, tem arraigadas e coaguladas opiniões que dificilmente si dissolvem. Sai da sua casa dia 17 de Dezembro e apesar das suas explicações via monochromatico onde era colorido. (...) O senhor fala tão claramente que receio pelo senhor. Acho um velho-jovem e bom chamado e conhecido Monteiro Lobato melhor homem que escritor, e acho-o o melhor e maior escritor do Brasil... O senhor tem umas maneiras exquisitas para o posto que ocupa.”"128

$\mathrm{Na}$ carta seguinte temos mais detalhes sobre como o leitor fora recebido por Lobato em sua casa:

“Caro Mestre sinto me agradecido e ao mesmo tempo honrado com a sua amizade; o mestre na verdade tem teorias sobre isto ou aquilo, tem sempre uma frase incentivadora, chama-me amigo, recebe-me em sua casa, tomo café em sua casa, café levado pela sua própria senhora, ganho livros...

Mestre o senhor não é um homem comum, é algo mais, esta em um ponto que nesta vida poucos chegarão(...)"129

A neta de Lobato, Joyce Campos Kornbluh, em suas memórias relembra um episódio, que poderia ter sido uma das visitas de Ari ao escritor, e que

\footnotetext{
${ }^{127}$ Carta de Ari Reginaldo Soares. Gália. SP. 12/02/1944. IEB/ARAS. Cx 4 P 2 doc 3.

${ }^{128}$ Carta de Ari Reginaldo Soares. São Paulo, 11/02/1945. IEB/ARAS. Cx 4 P 2 doc 6.

${ }^{129}$ Carta de Ari Reginaldo Soares. São Paulo, 17/03/1945. IEB/ARAS. Cx 4 P 2 doc 7.
} 
também nos revela a dimensão que o preconceito racial tinha na época, pois a própria cozinheira, ela também negra se recusava a servir o rapaz:

“Certa vez, bateu na nossa porta um rapaz negro de cujo nome não me lembro. Ele queria falar com meu avô, que marcava vários encontros na casa de meu pai, a uns trinta metros da dele. Ele convidou esse candidato a escritor para almoçar lá em casa. Precisava ver a raiva da Benta [cozinheira da família] diante do sujeito que tivera a indecência de sentar à mesa com meu avô! Minha mãe foi que serviu a mesa, porque ela se recusava a isso. Após o homem ir embora, meu avô foi conversar com Benta. Explicou que não se fazia esse tipo de coisa só por causa da cor da pele, mas ela respondeu: 'Ele não sabe o lugar dele.' Meu avô insistia que aquilo não passava de uma grande burrice, o moço era um escritor como ele, não havia motivo para ela não servir a mesa”130

Muitos eram os leitores que conheciam Monteiro Lobato pessoalmente, alguns marcavam esses encontros, outros o encontravam inesperadamente em uma livraria, na rua, ou em uma leiteria. Podemos imaginar a emoção de um encontro como esse, por meio da crônica de Frederico Branco, quando este, escrevendo em 1991 relembra:

“Naquele tempo, quando eu estudava no São Bento, meu pai e eu tínhamos uma invariável rotina semanal: todas as quartas-feiras ele me esperava na porta do colégio, de onde descíamos a Líbero Badaró, cruzávamos a São João e fazíamos uma agradável escala na antiga Livraria Teixeira (...) Nem sempre encontrava o que mais me interessava - já tinha superado a fase das historietas de fadas e de contos da carochinha. Geralmente procurava pelos livros de Lobato, que sempre me encantaram, a ponto de conhecer vários deles praticamente de cor. E naquela memorável quarta-feira, seu Pontes (...) já tinha à mão uma surpresa para mim:

- Olhe tem um novo Lobato aqui.

${ }^{130}$ CAMARGOS, Márcia. Juca e Joyce. Memórias da neta de Monteiro Lobato. São Paulo: Moderna, 2007. p. 96. 
E me estendeu do fundo da sua escrivaninha, o Dom Quixote para as crianças.

(...) Mas as quartas-feiras, o ritual estabelecido por meu pai não terminava com a visita semanal à Teixeira. Invariavelmente, ao deixar a livraria, subíamos a Líbero Badaró, cortávamos a praça do Patriarca e fazíamos uma segunda escala não menos agradável na Leiteria Campo Belo(...) E naquela extraordinária quarta-feira, outra surpresa me estava reservada na Campo Belo. Mal chegados o chá com torradas e o frappé pedidos, meu pai indicou um senhor solitário, sentado junto a entrada, que lia seu vespertino.

- Está vendo? É o Monteiro Lobato. Não quer falar com ele?

Era emoção demais num mesmo dia. Não somente encontrar um Lobato novo, inédito, como o próprio Lobato. Sendo muito tímido e arredio, não me atrevi a interpelá-lo. Que teria a dizer? Como reagiria ele?"131

No entanto, o menino consegue vencer sua timidez e estimulado pelo pai vai pedir a Lobato um autógrafo em seu novo livro. É Lobato que o convida para sentar:

\section{“- Senta ai.}

Obedeci, ainda constrangido e certo de que ele iria perguntar quantos anos eu tinha, onde estudava, o que pretendia ser quando crescesse - perguntas de praxe geralmente dirigidas pelos adultos as crianças.

Mas as dele não foram de praxe. Não as esqueci.

- Sabe quem foi Cervantes?

- Não senhor.

- E o Quixote, sabe?

- Esse eu sei. Era o cavaleiro andante.

- Pois é. Cervantes foi o pai do Quixote. Como eu sou da Emília.

- A Emília é sua filha? (...)”132

\footnotetext{
${ }^{131}$ BRANCO, Frederico. Postais Paulistas. São Paulo: Maltese, 1993. p.169-170.
}

132 BRANCO, Frederico. Postais Paulistas. São Paulo: Maltese, 1993. p.169-170 
Neste trecho relatado por Frederico Branco percebemos que mesmo em um encontro casual Lobato não deixava de perguntar sobre as leituras das crianças, na seqüência da conversa pergunta qual livro a criança havia lido por último. Tendo sido a resposta a Ilha do Tesouro, Lobato comenta também ter lido o livro e gostado muito. No diálogo também percebemos que o escritor se relacionava com as crianças de maneira incomum, o cronista se lembra de no início da conversa esperar as tradicionais perguntas sobre idade e escola, mas foi surpreendido com perguntas sobre literatura.

Nas cartas, por vezes, aparecem os registros dos encontros pessoais do autor com seus leitores, como no caso de Ari Soares. Mas, às vezes, esses encontros não se concretizam como vemos na carta de Nice Viegas, que tendo marcado um encontro com Lobato não consegue atingir seu objetivo. Escreve então em seguida para o autor:

"Niterói, 8 de junho de 942

Meu caro Monteiro Lobato

Escrevo-lhe hoje, não para abusar da sua grande bondade e gentileza, com uma correspondência que não lhe interessa, mas para agradecer-lhe a atenção da resposta que me deu, com tanta presteza, para me convidar à coisa que eu mais tenho desejado neste mundo: conhece-lo pessoalmente.

Quero contar-lhe, também, o meu desgosto, por ter perdido essa oportunidade e não ter conseguido encontra-lo nem pelos telefones. Quando telefonei para o número da sua indicação - 27-7644, na sexta feira, disseram: já saiu. Telefonei, em seguida, para a 'Civilização Brasileira' e pedi lhe avisassem que Nice Viegas iria falar-lhe sábado, às 2 e 30. Prometeram anotar e transmitir-lhe o recado, mas não creio que o tenham feito.

E sábado, às 2 e 30, estava eu, toda importante, por ter de falar ao melhor escritor do mundo, acompanhada de uma prima, indagando na livraria se Monteiro Lobato estava.

Disseram-me que na sexta feira tinha passado toda a tarde lá, mas que até aquela hora não tinha aparecido, podia ser que ainda viesse. Saí, voltando minutos depois, para ter a decepção, ao me informar de um Sr., que parecia ser o Caixa, se o meu querido escritor estava, e ele 
me respondeu: Ele já foi para S. Paulo. Não me conformei, disse que não era possível, pois tinha uma carta sua em que me dizia que lhe fosse falar sexta ou sábado, entre 2 e 3 horas da tarde.

E o tal homem me respondeu: ele foi, sim, eu até me despedi dele.

Monteiro Lobato, por ai avaliará o desgosto que tive, por não poder ter-lhe dirigido nem uma palavrinha!”133

Consultando as cadernetas pessoais de Monteiro Lobato, preservadas na seção de documentação da Biblioteca Monteiro Lobato, pode-se perceber que certos leitores estabeleciam com o escritor relações de amizade, muitas vezes duradouras. ${ }^{134}$ Seus nomes e telefones aparecem anotados em anos seguidos junto aos nomes de familiares e amigos pessoais. Verificamos que Lobato teve o cuidado de fazer uma anotação para se lembrar do encontro agendado com Nice Viegas. Na caderneta de número 5, utilizada provavelmente de 1940 a 1942, vemos escrito na folha reservada para a anotação de telefones para nomes que se iniciavam com a letra $\mathrm{N}$ : “ $\mathrm{N}$. Viegas $-5^{\mathrm{a}}$ ou $6^{\mathrm{a}}$ antes do almoço

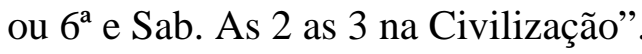

Na mesma caderneta temos o registro de telefone e endereço da Biblioteca Infantil Municipal, dirigida por Lenyra Fracarolli, e do telefone das "Villelas - Maria Elisa e Hilda" leitoras que se tornaram amigas de Lobato e da família, e a quem várias vezes Lobato se referiu como as "meninas das balas de cacau”, pois sempre enviavam como presente ao escritor as famosas balas. ${ }^{135}$ Nas cadernetas subseqüentes vemos o registro de vários leitores, sendo que na caderneta de número 7, relativa ao ano de 1944, é que temos o maior número de anotações sobre os leitores. Nessa caderneta temos anotação de endereço de: Ary Soares, Celso Bentim, Cordelia F. Seta, Myralda Coragem, Carlos Alceu Junqueira, Rosa Alice Godoy, Geo B. David, Hilda Villela e do pai de Lindenberg, José de Faria Ribeiro. Todos eles leitores que trocaram correspondência com Lobato. Sendo que muitos destes leitores tiveram contato pessoal com o autor. As cadernetas nos mostram que o

\footnotetext{
${ }^{133}$ Carta de Nice M. Viegas. Niterói, 08/06/1942. IEB/ARAS. Cx 1 P 2 doc 27.

${ }^{134}$ A Biblioteca Infantil Monteiro Lobato possui 9 cadernetas de telefone e endereço, que também serviam ao escritor para anotações. A primeira caderneta foi iniciada provavelmente em 1925, as subseqüentes muitas vezes tem data, o que parece constituir uma série, até o ano de seu falecimento. ${ }^{135}$ D. Hilda Villela Mertz, foi uma das principais organizadoras do arquivo preservado atualmente na Biblioteca Monteiro Lobato.
} 
relacionamento do escritor com seus leitores era bastante próximo e amigável, sendo assim completam o quadro esboçado pela leitura das cartas, pois nelas se percebe o alto grau de afetividade que os leitores nutriam por seu escritor favorito.

\section{“Querido Amigo”}

A relação afetiva dos leitores para com Lobato pode ser medida pela forma de tratamento utilizada, ou por sua própria ausência. São inúmeros os leitores que o tratam como: "Querido amigo”, "Caro mestre”, "Bom Amigo”. O usual é que a primeira carta tenha um tom mais formal e a partir da segunda ou terceira carta vemos que o leitor se sente mais próximo e passa a tratar o escritor com mais intimidade, possivelmente porque o próprio Lobato não deveria responder de maneira formal e rebuscada para seus leitores. ${ }^{136}$

Vejamos o exemplo das cartas escritas pela menina Cordélia F. Seta. A primeira carta de janeiro de 1944 se inicia com o seguinte tratamento: “Ilmo. Snr. Dr. Monteiro Lobato. Respeitosos Cumprimentos.” Na segunda carta refere-se ao escritor utilizando a mesma forma, na terceira retira o Dr. e escreve: "Ilmo. Snr. Monteiro Lobato. Saudações.” Na carta seguinte começa com: “Snr. Lobato. (O ‘ilustríssimo’ foi dar um passeio) Saudações.” Logo depois na carta subseqüente utiliza o já o “Caro Sr. Lobato” para finalmente trocar pelo já íntimo: “Amigo Monteiro Lobato”. Por essa série de cartas trocadas (são nove as cartas preservadas desta leitora no arquivo) vemos que os leitores quando iniciam a correspondência tendem a utilizar uma forma de tratamento bastante impessoal, mas no decorrer da correspondência isso se transforma. No caso desta leitora sabemos que ela só utilizou o termo “amigo”, depois de já o ter conhecido pessoalmente em uma visita que fez a São Paulo. Essa visita é comentada na carta, mas também temos dela um registro peculiar que é a matéria feita pelo jornal Diário da Noite, por ocasião do Congresso

\footnotetext{
${ }^{136}$ São poucas as cartas escritas por Lobato para seus leitores que foram encontradas durante a pesquisa, no entanto, pela continuação da correspondência entre leitor e escritor podemos ter uma idéia da resposta de Lobato.
} 
de Escritores Infantis, realizado na Biblioteca Infantil Municipal, em 1945, do qual Cordélia participou.

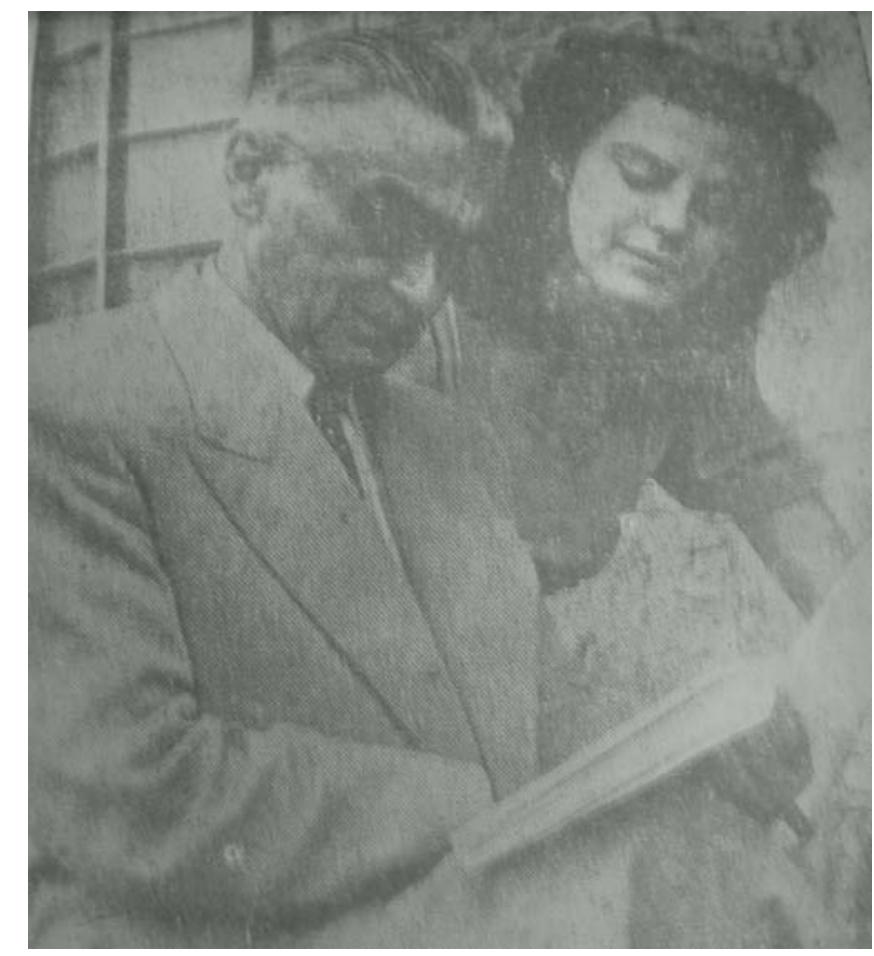

Lobato e Cordélia, 1945 - foto publicada no jornal O Diário da Noite. Seção de Bibliografia e Documentação. BML/PMSP.

Existem também poucos exemplos do contrário, crianças que começam a correspondência de forma espontânea e depois de algum tempo, quase sempre depois de um intervalo longo de tempo sem escreverem para o autor, começam a utilizar uma forma de tratamento mais distante. É o caso da correspondência de Edith Canto, sua primeira carta começa com um “Querido Monteiro Lobato”, a carta seguinte que temos no acervo é de quase dois anos depois e, talvez pela distância temporal entre as duas cartas, ela se inicia com "Meu Caro amigo Sr. Monteiro Lobato". A terceira carta se inicia com um simples "Sr. Monteiro Lobato", para logo na seguinte carta ser substituído por "Meu caríssimo amigo".

As formas de tratamento indicam como os leitores se colocavam em relação ao escritor, alguns são espontâneos e utilizam: “meu querido amigo” logo na primeira carta, e explicam só poderem imaginá-lo como amigo, tal é a intimidade que tem com sua obra. Outros leitores preferem usar as formas clássicas de tratamento, quase com receio de serem mal 
interpretados pelo escritor. Mas, mesmo utilizando maneiras de tratamento muito formais, é no desenrolar das cartas que percebemos o quanto os leitores o admiravam e tinham afeição por quem sempre foi o amigo das horas silenciosas de leitura. Como nos mostra Sarita:

“Querido Monteiro Lobato:

Digo assim porque desde pequenininha habituei-me tanto a você, 'tivemos’ tantas palestras juntos, na minha imaginação, que não teria jeito de tratá-lo de outra maneira. Creio que somos íntimos.”137

"Sou-lhe completamente desconhecida, apezar do Sr. ser um velho amigo meu."138

“(...) eu o admiro tanto que quero um retrato seu para ter em meu quarto ao lado do retrato de meu pai.”139

“Nosso bom amigo. Imagine que o Sr. é tão querido aqui em casa como o Papai Noel e olhe que esse velhinho é danado de querido, hein?!”140

Muitas vezes o escritor confunde-se com os personagens e parece ser imaginário para alguns leitores, como na resposta de Ari à primeira carta de Lobato:

“(...) Quando chegou a carta não quis acreditar fosse sua e a abri com mãos trêmulas para ver na parte superior do papel: Monteiro Lobato; então sim acreditei: não que eu julgasse que não me respondesse, não muito pelo contrário, é que o senhor parece uma pessoa inexistente."

Lobato é visto pelo leitores como um correspondente fiel, muitas vezes as crianças escrevem com espanto sobre como ele consegue responder a todas as cartinhas que recebe:

\footnotetext{
${ }^{137}$ Carta de Sarita. São Paulo, 26/04/1943. IEB/ARAS. Cx 1 P 2 doc 44.

${ }^{138}$ Carta de Helena. Maceió, 30/09/1944. IEB/ARAS. Cx 4 P 2 doc 24.

${ }^{139}$ Carta de Severino. Rio de Janeiro, 13/05/1945. IEB/ARAS. Cx 1 P 3 doc 22.

${ }^{140}$ Carta de Marjori. São Paulo, 25/05/1944. IEB/ARAS. Cx 2 P 1 doc 29.

${ }^{141}$ Carta de Ari Reginaldo Soares. Gália, 10/10/1943. IEB/ARAS. Cx 4 P 2 doc 1.
} 
“(...) eu me adimiro como você tem tempo de responder a todas as cartinhas."

"O fato de ter minha irmãzinha Lúcia Amélia recebido resposta de certa carta, que lhe escreveu, causou-me grande satisfação por verificar que o senhor é verdadeiramente o amigo das crianças, como demonstra nos livros."143

"Ha já muitos dias recebi seu retrato com sua assinatura. Fiquei muito satisfeita ao pensar que o Sr. ainda não se esqueceu de mim. Estimei imenso.”144

Já crescido o leitor Gilson Maurity Santos, escreve reatando a correspondência interrompida há quase dez anos. ${ }^{145}$ Quando recebe a resposta de Lobato, descreve assim o que sentiu:

"Era tamanha a emoção que tive de começar 3 vezes. Na quinta ou sexta linha eu perdia o fio do escrito e começava a imaginar: você escrevendo, você lendo a minha carta, você rindo, você sentindo-se contente, como eu esperava, de não se saber esquecido em mais um coração."146

Muitas vezes faltam palavras para descrever os sentimentos:

“(...) Gostaria de poder expressar meu contentamento mas isso é impossível”,147

Outros leitores como Myralda se queixam do atraso na resposta e escrevem unicamente para cobrá-lo:

“O fim desta cartinha é para a seguinte pergunta: a mais de 2 ou 3 semanas eu escrevi-lhe uma cartinha, e não obtive até hoje resposta. Porque é? O senhor esqueceu de mim, ou não gosta mais de mim? Das duas uma. Se o senhor não me escreveu por falta de tempo, não tem importância. Mas o senhor me escreva uma cartinha

\footnotetext{
${ }^{142}$ Carta de João Alphonsus Guimarães Filho. Belo Horizonte, 08/09/1943. IEB/ARAS. Cx 1 P 2 doc 50 .

${ }^{143}$ Carta de José Alberto. Recife, 07/08/1942. IEB/ARAS. Cx 2 P 1 doc 17.

${ }^{144}$ Carta de Edith Canto. São Paulo, 24/04/1943. IEB/ARAS. Cx 1 P 2 doc 18.

${ }^{145}$ No livro de Eliane Debus ver as cartas enviadas por Lobato a Gilson.

${ }^{146}$ Carta de Gilson Maurity Santos. Rio de Janeiro, 01/04/1943. Biblioteca Monteiro Lobato. doc 997.

${ }^{147}$ Carta de Ary Reginaldo Soares. Gália, 13/01/1944. IEB/ARAS. Cx 4 P 2 doc 2.
} 
nem que for só 3 linhas. Com tanto que me dê suas notícias. Sim? Espero breve respostas!" 148

Outros leitores transferem a culpa pelo atraso na correspondência aos correios:

“(...)Espero não ter sido esse o motivo da não resposta de três ou quatro cartas que escrevi antes desta e confiando menos no correio que na atenção do amigo, foi que agora passo a redigir a minha quinta carta."

A desconfiança pelo serviço prestado pelos correios, muito comum na época, ${ }^{150}$ é mencionada em várias cartas que solicitam, então, resposta em cartas registradas como faz Evangelina, que morava em uma fazenda:

“(...)Si pretender atender o meu pedido é favor mandar registrado para não se perder e para que não tenha que recorrer ao ‘faz de conta’ da Emilia, mando junto um cartão com o endereço.»151

O carinho e afeto para com o autor também estão presentes nas muitas cartas que são escritas com o intuito de desejarem melhoras por ocasião de alguma doença. Como o menino Antonio Henrique:

“Soube que o senhor está muito doente. Faço muitos votos para melhorar." 152

Alguns leitores que já se correspondiam com Lobato organizam uma carta coletiva com todos os colegas de sua classe na escola, como faz o menino Severino. Depois dos votos de melhora vem uma longa lista com a assinatura de todos os meninos e da professora:

"Nós desejamos ao grande escritor completo restabelecimento. Sua saúde é a saúde de Dona Benta, Tia Nastácia, Emilia, Rabicó, Visconde...

Essa gente é a nossa alegria e o nosso orgulho.

Grandes abraços e muita saúde.»153

\footnotetext{
${ }^{148}$ Carta de Myralda Elisa Coragem. Guaxupé, 23/11/1945. IEB/ARAS. Cx 2 P 2 doc 10.1.

149 Carta de Celso Bentim. Curitiba, 05/03/1945. IEB/ARAS. Cx 4 P 2 doc 15.

${ }^{150}$ LEMOS, Renato. Bem traçadas linhas: a história do Brasil em cartas pessoais. Rio de Janeiro: Bom texto, 2004.

${ }^{151}$ Carta de Evangelina Barbosa de Morais. Fazenda Sto. Inácio, 11/11/1939. IEB/ARAS. Cx 2 P 1 doc 7.

${ }^{152}$ Carta de Antonio Henrique Abreu Amaral. Santos, 26/07/1945. IEB/ARAS. Cx 2 P 2 doc 2.
} 
Em algumas cartas o universo imaginário se mescla à realidade, e Humberto Pires assim como sua irmã Vilma, que dizem ter ficado sabendo de sua doença por comentários de seus pais, imaginam poder recorrer ao Doutor Caramujo ou Visconde. Mas, como que não confiando muito em um remédio de "faz-de-conta", se prontificam a solicitar a um parente farmacêutico o remédio adequado:

“Soube que o senhor está doente. Fiquei muito triste. Com certeza o Visconde está tratando do senhor, ou o Dr. Caramujo.

(...)Papai foi ao teatro para assistir sua festa mas arrastou a mala. Disseram que o senhor estava doente.

Se você não ficar bom com o remédio do Visconde, eu mando pedir um a padrinho. Ele é farmacêutico e mora no norte.”154

"Quero que você fique bom logo e receba um abraço da sua amiguinha”"155

A preocupação com o bem estar do escritor também estava presente quando de sua prisão em 1941. Algumas cartas mencionam sua prisão, as crianças escrevem se solidarizando, mesmo sem saberem os motivos que o levaram a ser preso, assim como também ficam felizes com sua liberdade. No entanto ao compararmos as datas das cartas com o período em que esteve preso, de março a junho de 1941 percebemos que os leitores se confundiram, ou receberam alguma notícia sobre sua liberdade, que não era verídica, como na carta de Edith Canto, escrita em 19 de abril do mesmo ano, dois meses antes de sua saída da prisão:

"Ha tanto tempo que não lhe escrevo - será que o Sr. ainda se lembra de mim?

Soube ha poucos dias que o Sr. foi posto em liberdade.

Congratulo-me deveras consigo, apesar de não conhecer os motivos de seu aprisionamento”,156

\footnotetext{
${ }^{153}$ Carta de Severino de Moura Carneiro Junior. Rio de Janeiro, 27/07/1945. IEB/ARAS. Cx 1 P 3 doc 24.

${ }^{154}$ Carta de Humberto Pires. São Paulo, 27/08/1945. IEB/ARAS. Cx 1 P 3 doc 20.

${ }^{155}$ Carta de Vilma Pires. São Paulo, 27/08/1945. IEB/ARAS. CX 1 P 3 doc 17.

${ }^{156}$ Carta de Edith Canto.Botucatu, 19/04/1941. IEB/ARAS. Cx 1 P 2 doc 16.
} 
A menina Nicean, de oito anos, escreve em 14 de abril, de Manaus, por sua carta percebemos como a notícia da prisão de Lobato repercutia em todo o país:

"Venho por meio desta cartinha congratular-me com o Sr. pela liberdade que acaba de obter.

Quando li o telegrama mandando prende-lo, não imagina como fiquei triste! É que, embora pequenina, pois tenho oito anos, gosto imensamente de ler e o Sr. é meu autor predileto!”157

As informações sobre o escritor parecem mesmo um tanto quanto defasadas, pois o menino Lenildo, de 11 anos residente no Rio de Janeiro, escreve em setembro sobre a sua prisão:

"Venho escrever-lhe esta, para saber as notícias, pois soube que o snr. está detido; então fiquei muito triste, por ser um adimirador de seus livros apezar de só ter lido 3 (...)”158

Devemos nos lembrar que durante o Estado Novo, a censura aos jornais era severa, e tanto a prisão como a liberdade de Lobato foram proibidas de serem divulgadas. Assim as crianças dependiam do que pais, familiares e amigos comentassem sobre o caso, e mesmo os adultos tinham dificuldades de saber o que de fato acontecia no panorama nacional. Contudo, a prisão de Lobato parece ter permanecido durante bastante tempo na lembrança de crianças e jovens, pois uma jovem de apelido Sarita escreve em 1943 comentando esse momento:

“(...). Artigos que saíram antes da prisão, eu os devorei todos. Não pude visita-lo, mas ficou-me sempre na lembrança. Não o esqueci um só momento.”159

Vemos pelas cartas escritas por ocasião de uma doença ou da prisão de Lobato, que a leitura de suas obras de Lobato fazia com que as crianças leitoras se sentissem próximas ao escritor, se preocupassem com ele. Um dos motivos para esse sentimento pode estar relacionado à maneira pela qual Lobato

\footnotetext{
${ }^{157}$ Carta de Nicean Serrano Telles de Souza. Manaus, 14/04/1941. IEB/ARAS. Cx 1 P 2 doc 34.

158 Carta de Lenildo Pinto. IEB/ARAS. Rio de Janeiro, 15/09/1941. Cx 1 P 2 doc 35.

${ }^{159}$ Carta de Sarita. São Paulo, 26/04/1943. IEB/ARAS. Cx 1 P 2 doc 44.
} 
construía suas obras. Em muitos momentos no desenrolar da narrativa o próprio escritor aparece e é objeto de comentários, como neste de Narizinho:

“- Exigente! Você já anda bem famosinha no Brasil inteiro, Emília, de tanto o Lobato contar suas asneiras. Ele é um enjoado muito grande. Parece que gosta mais de você do que de nós. É só Emília para cá, Emília para lá (...)»160

Essa construção na qual os personagens falam de seu autor aparece em muitos momentos, mas especificamente nas obras publicadas a partir da década de trinta. Este aspecto metaliterário é uma das características importantes do modernismo, na qual o escritor se revela ao leitor como criador literário, possibilitando assim que ele seja percebido de forma clara pelos leitores. Colabora também com essa percepção o fato de Monteiro Lobato, repetidas vezes, aparecer em entrevistas dadas a rádios e também jornais ou revistas. Em uma delas: na da Revista Diretrizes, ele claramente fala das cartas recebidas o que deve ter estimulado ainda mais o contato dos leitores com o escritor por este meio. $^{161}$

Quando os leitores já são jovens adultos muitas vezes escrevem agradecendo ao escritor, a quem consideram um professor, um mestre e até mesmo um pai. O leitor Gilson Maurity Santos, já citado, escreve a Lobato comentando como a leitura de seus livros influenciou-o:

“Com seus livros na cabeça, quase decorados, eu fiz meus primeiros alicerces literários. Deles me vieram a imaginação enorme que me pôe hoje a olhar para o chão, sem ver, a cismar em coisas e gatos e historias que eu invento. E dali veio a vontade de ler e o entusiasmo que tenho pelos livros. E o carinho com que os trato. E por fim, abrasante, violentíssima, veio a loucura que tenho de escrever.

Mais diretamente de V., da clareza do seu estilo, do que das suas criaturas, partiu esse raio que me excita a imaginação e o desejo de fixa-la no papel.”

\footnotetext{
${ }^{160}$ MONTEIRO LOBATO. Dom Quixote das crianças. 8.ed. São Paulo: Ed. Brasiliense, 1957. p.61. 161 "Um governo deve sair do povo como o fumo sai da fogueira” In: MONTEIRO LOBATO. Prefácios e Entrevistas. 8.ed. São Paulo: Ed. Brasiliense, 1957. p. 155- 166.
} 
Assim como descreve Gilson, em sua infância o escritor não só o influenciou, fazendo dele um leitor voraz, como também despertou a imaginação com que via o mundo ao seu redor, mais do que isso o levou ao desejo de se tornar escritor. Não tendo sido a única influência, foi a primeira e fundamental, como diz logo em seguida:

“É lógico que muita gente tem influído em minha formação e particularmente em meus pendores para a literatura, para esse amor enorme que tenho para os livros. Mas V. foi a base. Foi e é a parte fundamental desse edifício que tem pouco mais de um andar (se é que já tem um andar...)

(...)É isso tudo, meu amigo, que me faz escrever para V. É esse sentimento de gratidão e amizade e principalmente de admiração.

É também para lembrar que daquela meninada cheia de entusiasmo pelos escritos, pelo menos um (mas tenho certeza de que existem muitos outros assim) nunca o esqueceu e guarda com carinho a lembrança do Monteiro Lobato. Começam agora a pensar e agir os seus primeiros filhos literários (vamos dizer assim). Você começa a ver os primeiros resultados do seu trabalho magnífico, edificante.”162

O anseio por se tornarem escritores ou mesmo tradutores pode ser encontrado em muitas das cartas, mesmo a de crianças com idades de oito ou nove anos. O interessante é notar que muitas vezes os leitores já se julgam escritores por terem imaginado uma história, como nos diz Raymundo de Araújo, carioca de oito anos:

“Olhe 'seu' Monteiro tenho de lhe dizer uma coisa: a minha idade, são 8 anos, e outra: que tenho no papel da cabeça escritos tres livros: 'Jak e Alfred na Groenlandia’, 'Tom Water e seus irmãos na Dinamarca' e 'O caso do bando Sereia de Prata'. Quando escreve-los (no rascunho é claro) mandarei para S.Paulo para o senhor corrigir e prefacionar."

\footnotetext{
${ }^{162}$ Carta de Gilson Maurity Santos. Rio de Janeiro, 20/03/1943. Cx 4 P 2 doc 53.

${ }^{163}$ Carta de Raymundo Araújo. Rio de Janeiro, 30/01/1937. IEB/ARAS. Cx 1 P 2 doc 20.
} 
Raymundo não só deseja publicar seus livros, mas solicita ao escritor que os corrija e faça o prefácio. Também Lucilia, de dez anos, diz que vai publicar um livro, e exige que Lobato seja seu leitor:

“Eu vou publicar um chamado ‘Aventuras de Halley’ e espero que o Senhor leia, e acho muito justo que assim o fasa, porque eu já li todos seus livros.

De sua constante leitora”164

A carta de Lucilia e de Raymundo, assim como muitas outras, mostram como as crianças se colocavam na mesma altura e com os mesmos direitos do próprio autor. No geral a correspondência para Lobato tem essa característica, as crianças não se julgam inferiores, muito menos se comportam como se estivessem a frente de um ícone da literatura. Ao contrário exigem são, em certa medida, petulantes, lembrando um pouco os próprios personagens de Lobato, principalmente Emília. Provavelmente essa postura só era possível devido à própria maneira como Lobato construiu suas personagens, estimulando seus leitores a se comportarem como Narizinho, Pedrinho e Emília. Apesar de serem um tanto quanto atrevidos e ousados, os leitores de Lobato não deixavam com isso de nutrir e expressar pelo autor um grande carinho.

São inúmeras as cartas que explicitam a mesma admiração, gratidão e amizade. Esses sentimentos que, claramente aparecem em muitas cartas, nascem da leitura de suas obras. Percebe-se que os leitores têm para com Lobato uma relação afetiva porque, mais do que ensinar geografia, aritmética e história, as obras de Lobato divertiram e fizeram com que as crianças passassem a pensar o mundo de outra forma.

Assim, alguns leitores agradecem pelos conhecimentos adquiridos ou pelos momentos de prazer e desprendimento passados em companhia dos personagens do Sítio, como a leitora Miriam:

“Não tenho nada a pedir ou a tratar. Venho apenas agradecer-lhe o muito que fez por mim atravéz de seus livros.

Desde que eu tinha 6 anos, quando ainda morava na Cidade do Salvador da Baia. (agora Bahia pela ortografia de janeiro de 1944) eu

${ }^{164}$ Carta de Lucilia Alves Carvalho. Rio de Janeiro, sem data. IEB/ARAS. Cx 1 P 3 doc 46. 
sonhava com o seu sitio do Picapau Amarelo, com o Sr., com seus personagens. (...)

Foi durante o meu exame vestibular que me veio a idéia de escreverlhe.

Eu estava neurastênica(...)

O snr. pode imaginar o que era.

Bom, eu sabia geografia mas estava já num ponto em que qualquer compêndio me dava náuseas.

Então, entra o Snr em cena. Eu não precisava + estudar, mas não me sentia bem sem faze-lo. Abri então a Geografia de D. Benta que me desanuviou o espírito e me deixou em um estado de ânimo milhões de vezes melhor. Conto com o senhor para que nunca conte isso a ninguém, porque é algo muito pessoal, que agradará ao senhor, mas não deixará meu prestígio muito alto. O snr. compreende o que eu quis dizer, não é?

Hoje, quando já faço parte da Faculdade (...) julgo-me na obrigação de agradecer-lhe o que fez por mim.

Não foi pouco!

Eu sou-lhe muito grata, assim como lhe são gratas todas as crianças e adolescentes e mesmo, - e somente- os adultos de compreensão de grau elevado, mas que por comodismo, falta de tempo, ou qualquer outra cousa, nunca se sentaram para contar-lhe quanto lhe devem.”165

Ou da leitora Helena, quando já tem 20 anos e que escreve para Lobato contando o quanto ele a ajudou nos trabalhos escolares:

“No colégio, consegui ótimas notas em Historia da Civilização, pois, em vez de resumir os pontos pelos livros adotados, valia-me do seu Historia do Mundo para as creanças, o que os tornava mais interessantes e bem diferentes dos das outras colegas.”166

Mas muitos jovens leitores, assim como Gilson, valorizam em Lobato esse pensar com liberdade e fazem de Lobato seu confidente, um deles é Celso

\footnotetext{
${ }^{165}$ Carta de Miriam. São Paulo, 25/03/1944. IEB/ARAS. Cx 4 P 2 doc 18.

${ }^{166}$ Carta de Helena. Maceió, 30/09/1944. IEB/ARAS. Cx 4 P 2 doc 24.
} 
Bentim $^{167}$, do qual temos preservadas no arquivo oito longas cartas. Nessas cartas ele relata suas dificuldades e também suas conquistas. Sua primeira carta é de dezembro de 1943, e ele se dirige ao escritor, como seu filho mental:

“Prezado Amigo Dr. Monteiro Lobato.

Saúde em família.

Sempre costumamos, nós, os filhos, quando temos algum êxito, comunicarmos aos nossos pais, a-fim-de se orgulharem de nossa vitória ou de nossa capacidade; quando se trata de filho mental, quando o aluno tem, exteriormente falando um êxito, este comunica ao seu pai mental, que é o mestre, a-fim-de este, ver que seu filho é de capacidade ou se esforça; o mesmo se deu comigo agora.

(..)Assim sendo, esta poesia fica-lhe como lembrança e com muito afeto despede este filho mental (...)"168

A correspondência nos mostra que o leitor visitava frequentemente o escritor. Em uma das cartas Bentim pede desculpas por ter perdido o livro que Mme Dupré havia dado a D. Purezinha e a Lobato, nesta mesma carta o leitor fala da afeição que nutria por Lobato:

“Não sei Dr. Monteiro Lobato, como agradecer a sua bondade para comigo; o que mais admira é a distância que nos separa, tanto na idade como na posição social; e vejo que a sua tolerância para comigo tem sido tão grande! Às vezes não sei como pensar. (...)

- E eu, um qualquer, desconhecido, moreno queimado, de tão pouca maturidade que quase não se sabe o meu estilo, os pendões natos no meu espírito, vejo-me como num sonho, atendido pelo grande Monteiro Lobato, que é o senhor, nome que posso dizer que é superlativo de grandeza. Às vezes eu fico admirado ao pensar que com tão pouca idade, sou atendido e o senhor conversa comigo como se eu fosse gente grande, ou uma pessoa ilustre, como sempre diz: ‘Ilustre! 169

\footnotetext{
${ }^{167}$ Sobre o leitor Celso Bentim é interessante lembrar que ele inicia a correspondência em 1943, e as cartas preservadas no IEB vão até julho de 1945. No entanto, temos a informação de que este leitor estava presente na última entrevista dada a rádio por Lobato, é o autor quem fala: "Vou pedir ali ao amigo Bentim que me ajude, que me dê um tema para esta dissertação. Vamos lá Bentim, me dê uma idéia, me ajude...”. Assim vemos que o leitor, de 1943, se transformou em amigo em 1948.

${ }^{168}$ Carta de Celso Bentim. São Paulo, 27/12/1943. IEB/ARAS. Cx 4 P 2 doc 10.

${ }^{169}$ Carta de Celso Bentim. São Paulo, 29/08/1944. IEB/ARAS. Cx 4 P 2 doc 13.
} 
Nessa carta percebemos que o leitor Celso se colocava em uma situação hierarquicamente inferior a que ele acreditava ser a do escritor, a admiração que nutria por Lobato era também resultado da forma pela qual o autor o tratava: “como seu eu fosse gente grande”. É interessante notar que o leitor, quando escreveu essa carta, tinha dezessete anos. Era um jovem rapaz, sua maneira de se colocar se comparada à das crianças de oito ou nove anos, é muito diversa, revela-nos um indivíduo comum frente a uma grande figura da literatura, que contrariamente ao esperado chamava de "ilustre” o jovem leitor.

\section{Os leitores se transformam em personagens}

Como vemos, a relação de Monteiro Lobato com seus leitores ultrapassava em muito o que poderia ser esperado entre um escritor e seus leitores. As crianças e jovens que travavam conhecimento com o autor por meio de seus livros não se contentavam com uma foto, ou uma carta escrita pelo autor, queriam conhecê-lo em carne e osso, se transformavam em amigos que visitavam sua casa, davam palpites para novas aventuras, pediam para entrar em seus livros. São muitas as passagens na correspondência que fazem pedidos incisivos como o da leitora Bú:

"Veja se você pode me encaixar nos livros das 12 Aventuras de hercules. Tia Zezé me disse que você vai me por num livro, mas eu quero que você me ponha em todos."

A primeira obra na qual aparecem crianças leitoras é Circo de Escavalinhos, publicada pela primeira vez em 1929, com ilustrações de Belmonte em quase todas as suas 31 páginas. Nesta primeira edição aparecem dez crianças que provavelmente eram filhas de amigos de Monteiro Lobato. Na narrativa haviam sido convidadas para o Circo que Pedrinho e Narizinho estavam organizando.

Das crianças mencionadas em Circo de Escavalinhos somente uma tem suas cartas preservadas no acervo pesquisado, tratava-se de Alariquinho, filho de Alarico Silveira secretário de Washington Luís, durante o governo do Estado

${ }^{170}$ Carta de Bú. São Paulo, 04/09/1944. IEB/ARAS. Cx 2 P 1 doc. 34. 
e também na presidência. É assim que o escritor comenta em carta ao amigo o que pretende fazer no livro a ser lançado:

"Recebi uma cartinha muito curiosa do Alariquinho e agora quero que me mandes um retratinho qualquer dele, de corpo inteiro, um instantâneo. Preciso para o seguinte. Estou escrevendo um novo livro para crianças em que há uma grande festa no sítio de Dona Benta, para a inauguração do circo de cavalinhos que Narizinho organizou. Para esta festa foram convidados, e compareceram vários meninos e meninas de carne e osso da atual geração, entre os quais o Sr. Alariquinho, a Maria da Graça, do Sampaio, e outros. Quero ter os retratinhos deles para que o desenhista daqui que me vai ilustrar esse livro apanhe a feição dos convidados. Fica interessante e vai ser uma alegria para eles.”171

Assim sabemos por esta carta que uma das meninas que visita o Sítio por ocasião do Circo de Cavalinhos era filha de Sebastião Sampaio, cônsul brasileiro em Nova York, na ocasião em que Lobato era adido comercial. Ao que parece essas crianças não haviam pedido a Lobato para aparecer no Sítio de Dona Benta que, como veremos, era um dos pedidos mais comuns em todas as cartas. A justificativa que Lobato dá ao amigo para essa inserção é: “fica interessante, e vai ser uma alegria para eles”. Interessante, pois era muito incomum que crianças de carne e osso aparecessem em obras literárias e, realmente, deveria ser uma grande felicidade se tornar personagem de Lobato. Pois nessa primeira edição o escritor não só faz com que as crianças sejam convidadas e compareçam, mas faz com que elas contracenem com os personagens das histórias de fadas, como o Gato de Botas, princesas como Cinderela, e muitos outros personagens de outras obras literárias como Raggedy Ann e Alice, e também das histórias em quadrinhos como o Gato Félix. Logo após a chegada das crianças no Sítio:

"Pedrinho teve que aparecer e explicar que ainda não tinham chegado os convidados do Paiz das Maravilhas.

A explicação causou grande contentamento porque nenhum dos presentes sabia que o pessoal do reino das fadas também vinha assitir ao espetáculo. E essa alegria se transformou em surpreza quando o primeiro

${ }^{171}$ MONTEIRO LOBATO. Carta a Alarico Silveira. Nova Iorque, 07/02/1929. Cartas Escolhidas. 3. ed. São Paulo: Ed. Brasiliense, 1964. p.276. 
deles apareceu. Era Aladino, com sua lâmpada maravilhosa na mão. Chegou e foi trepando as archibancadas como se fosse um velho freqüentador de circos. Todos os olhares se cravavam nele, porque era o primeiro príncipe encantado em carne e osso que aquelas crianças estavam vendo.

- Senador, deputado ou coronel são creaturas que eu conheço, disse o Alariquinho á Maria da Graça. Até presidente de república eu conheço e estou enjoado de ver. Mas príncipe encantado, é o primeiro.

(...)Nisto correu a notícia que havia chegado uma princeza. E era verdade. Dalli a pouco Cinderella entrou no circo pela mão de Narizinho e foi sentar-se junto da Therezinha Malhado, que abriu a boca de espanto.

A princeza sorriu para ella e pediu notícias de sua mãe e irmãzinhas. Mas a emoção da menina foi tanta que ficou de língua presa e não poude responder."172

Percebemos que, já em 1929, Lobato utilizava recursos como esses que nos remetem a metaliteratura, construindo uma obra que dialogava não só com os tradicionais contas de fadas, mas os atualizava dialogando com os novos personagens do cinema e dos quadrinhos. Trechos como esse onde os personagens das histórias de fadas conversam e interagem com as crianças foram retirados da narrativa, quando esta foi incorporada a Reinações de Narizinho, como um dos capítulos, em 1931. Frases que na primeira edição eram ditas pelas crianças passaram a ser ditas por personagens como o Gato Felix. Essa modificação bastante estrutural da obra fazia com que ela não ficasse tão circunscrita, e talvez pudesse ser melhor compreendida por um público leitor mais amplo.

No acervo pesquisado temos somente duas cartas de Alariquinho, uma que não está datada, mas tudo indica, foi escrita assim que o menino recebeu o livro Circo de Escavalinhos:

${ }^{172}$ MONTEIRO LOBATO. Circo de Escavalinhos. São Paulo: Cia Editora Nacional, 1929. 


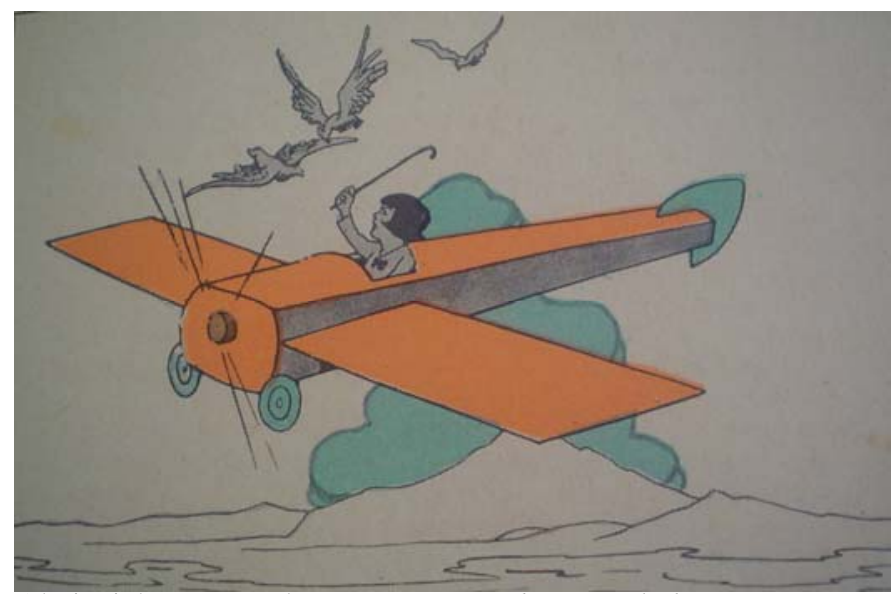

Alariquinho no aeroplano, em O Circo de Escavalinhos.

Desenho de Belmonte

“Ao amigo íntimo Monteiro Lobato

Muito obrigado do livro que eu gostei muito. Eu achei muito engraçado eu aparecer de aeroplano no sítio do picapau amarelo. Como é que o Edgard me disse que a empregada ahi da sua casa varreu a Emilia para o lixo e eu vi ella ahi no livro?

Logo vi que era peta do Edgard porque a Emília é a mais engraçada de todos e eu não gosto de livro que não tenha a Emília. Eu também achei muito engraçado aquellas cartinhas, correndo com perninhas e tudo."173

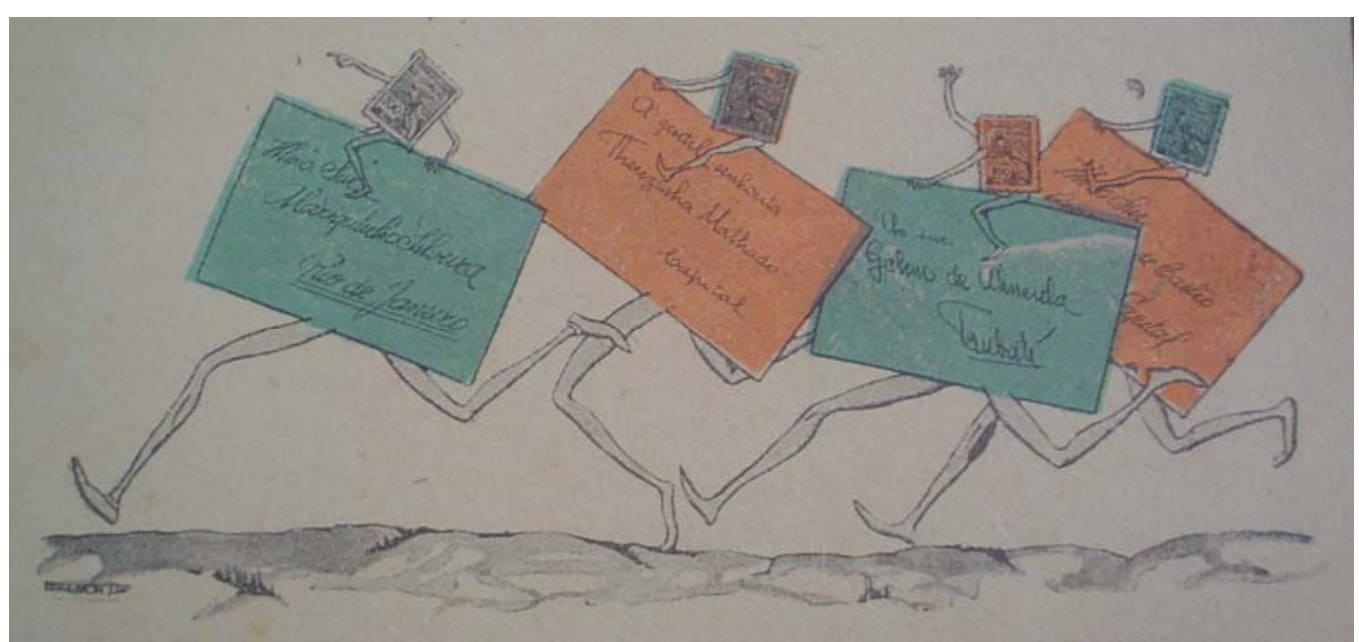

O Circo de Escavalinhos - desenho de Belmonte.

Seção de Bibiografia e Documentação. BML/PMSP.

\footnotetext{
${ }^{173}$ Carta de Alarico Silveira Jr. Sem Local e Sem data. Provavelmente de agosto/setembro de 1929. IEB/ARAS. Cx 1 P 2 doc. 3.
} 
Na resposta da criança percebemos que ela se ateve mais às ilustrações que a sua interação com os personagens. Pois, os dois momentos mencionados por ela diziam respeito ao desenho dele próprio em um aeroplano vermelho e as cartas que tinham perninhas. Mas o leitor não deixa de mencionar que prefere a Emília, dentre todos os personagens, e pergunta pelo Visconde.

Apesar dos trechos onde as crianças aparecem terem sido suprimidos nas edições posteriores de Circo de Escavalinhos, Lobato não deixaria de colocar outras crianças como personagens em outros livros da série. A próxima a aparecer no Sítio foi Cléo, filha de Octalles Marcondes Ferreira, na obra Caçadas de Pedrinho, editada em 1933. A menina visita o Sítio e vive aventuras com os netos de Dona Benta. Logo no início ela é apresentada como uma menina que falava pela rádio e escrevia cartas para Narizinho, isso porque por volta de 1931 ela havia falado juntamente com Lobato na rádio.

“- Quem é você, menina? - perguntou Dona Benta.

- Não me conhecem? - tornou a desconhecidazinha com todo o espevitamento. Pois sou a Cléo!, que falava pelo rádio e de vez em quando escrevia cartas a Narizinho dando idéias de novas aventuras”"174

Durante o desenrolar da história a menina desempenha um papel semelhante a de Narizinho e Pedrinho. Tal presença é tão importante que é mencionada na carta da leitora Marila Gravenstein Borges, que também quer participar das aventuras:

"Eis o caso: tanto tenho vivido entre os seus personagens que desejaria 'viver' num próximo livro onde a turma de D. Benta aparecesse.

Assim uma cousa como aconteceu á Cleo.

Ora, caso minha ideia pegue, e seria essa minha maior alegria, talvez lhe interessasse saber alguma cousa a meu respeito para poder transplantar-me para o sitio dos peraltas.”

Seis anos depois o desejo de Marila é atendido, e ela, seus dois irmãos: Mário e Estila, assim como muitos outros leitores e até mesmo os dois netos de Lobato aparecem para uma visita surpresa ao sítio. Na obra O Picapau Amarelo diversos leitores resolvem fazer uma visita a Emília, são liderados por Maria de

\footnotetext{
${ }^{174}$ MONTEIRO LOBATO. Caçadas de Pedrinho. 7. ed. São Paulo: Ed. Brasiliense, 1957. p. 50.

${ }^{175}$ Carta de Marila Gravenstein Borges. São Paulo, provavelmente 1932. IEB/ARAS. Cx1 P1 doc 2.
} 
Lurdes, ou Rãzinha, mas infelizmente chegaram em um momento no qual todos os personagens haviam viajado para participar do casamento de Branca de Neve. Mesmo assim visitam o Sítio, andam no Quindim, rinoceronte de estimação, e se regalam com as frutas do pomar. Foi a forma que Lobato arranjou para atender aos pedidos dos leitores, que respondem agradecendo:

"Isso sim, isso chama-se surpresa! Nunca tive a honra de aparecer em um livro, por isso a minha alegria foi do tamanho de um bonde ou do Quindim.”176

"Pois bem: a Nice Viegas que teve a honra de aparecer no seu livro ‘O Sítio do Picapau Amarelo’, está morando em Niterói, na rua Pe Anchieta - 19 e há muito tempo vem pensando em continuar a nossa correspondência."177

Mas coube à leitora Maria de Lurdes, ou Rãzinha, um dos papéis mais notáveis de toda a obra de Lobato. Na obra A Reforma da Natureza Emília escreve à leitora convidando-a a reformar a natureza:

“Assim que se pilhou sozinha, Emília correu a máquina de escrever e bateu uma carta para uma menina do Rio de Janeiro com a qual andava já a algum tempo se correspondendo e planejando coisas.

'Querida Rã:

Estou só - só-só-ró-só-só! Todos foram para a Europa arrumar aqueles países mais amarrotados do que latas velhas e agora preciso que você venha passar uma temporada aqui. Você é das minhas: das que não concordam. Podemos realizar aquele plano de reforma da Natureza.(...)"178

E assim a leitora atende ao pedido de Emília e chegando ao Sítio se põe junto à boneca a reformar a Natureza. Percebemos pelas três cartas encontradas no acervo pesquisado, que muitas das transformações sugeridas pela Rã no decorrer do livro, de fato foram dadas a Lobato por meio da correspondência da leitora com o escritor. Provavelmente o número de cartas trocadas entre os dois

\footnotetext{
${ }^{176}$ Carta de Flavio Lange de Morretes. São Paulo, 30/10/1940. IEB/ARAS. Cx 1 P 2 doc 33.

${ }^{177}$ Carta de Nice Viegas. Niterói, 29/05/1942. IEB/ARAS. Cx 1 P 2 doc 26.

${ }^{178}$ MONTEIRO LOBATO. A Reforma da Natureza. 7. ed. São Paulo: Ed. Brasiliense, 1957. p. 202.
} 
foi maior do que o preservado, pois uma das cartas encontradas no acervo está incompleta e em nenhuma delas existe uma apresentação, o início da correspondência. As cartas já começam comentando a Reforma, e dando inúmeras idéias para o escritor. Algumas delas vão de fato parar no livro, como as alterações feitas em Rabicó e em Quindim. Mas no decorrer da história são inúmeras as sugestões da menina, muitas vezes tão estapafúrdias que Emília chega a desconfiar que ou a menina é maluca ou estava sabotando sua obra reformatória. E as duas têm o seguinte diálogo:

“- Parece incrível, Rã! - disse ela. Chamei você para me ajudar com idéias na reforma, mas até agora não saiu dessa cabecinha uma só coisa aproveitável - só 'desmoralizações...'

- Isso não! A idéia das tetas com torneiras na Mocha foi minha e você gostou muito. A da pulga também.

- Só essas. Todas as outras eu tive de jogar no lixo. Vamos ver mais uma coisa. Que acha que devemos fazer para a reforma dos livros?"”179

Dessa forma durante toda a narrativa, as duas, Emília e Rã, dialogam e vão transformando os animais do Sítio, a casa, o mobiliário e os livros. Emília e a menina criam uma vaca que tem torneirinhas para que o leite saia por um método mais prático, cadeiras que flutuam, pulgas lentíssimas e os livros comestíveis entre muitas outras invencionices. A leitora participa da história de seu início até o final quando, ao voltar, Dona Benta convence Emília a desfazer a maior parte das reformas. O interessante é que em uma primeira leitura não se pode imaginar que tal menina não seja somente um personagem criado por Lobato, assim como também não imaginamos que as idéias de transformar a Natureza tenham sido dadas pela leitora.

Infelizmente não conseguimos apurar quem teria sido Maria de Lurdes, ou Rã, sabemos pelas cartas que vivia no Rio de Janeiro, que deveria ter por volta de 1939, cerca de onze anos. Temos ainda uma indicação da leitora em uma carta de Gilson Maurity Santos, que também residia no Rio de Janeiro:

“Quis retardar essa carta, para procurar a Maria de Lourdes (a Rã) conversar com ela, e depois contar a entrevista.

\footnotetext{
${ }^{179}$ MONTEIRO LOBATO. A Reforma da Natureza. 7. ed. São Paulo: Ed. Brasiliense, 1957. p. 235.
} 
Mas qual! A colega estava cheia e eu precisava dizer o que acontecia comigo."

Por esse trecho não conseguimos saber se quem havia apresentado um ao outro tenha sido o próprio Lobato, ou se já se conheciam em outras circunstâncias. O importante é notar que por meio das cartas poderia se estabelecer uma rede de contatos entre os leitores. Em alguns momentos vemos que irmãos escrevem depois de verem que o escrito respondia aos leitores, ou mesmo amigos de escola que mencionam ter visto a resposta recebida pelo colega.

De qualquer forma as cartas estão sempre comentando e dando novas idéias de aventuras para os personagens do Sítio. Os leitores pedem para viver uma aventura com eles ou então gostariam de ver seu bichinho de estimação nas obras. Aos pedidos Lobato sempre atende, mas muitas vezes o personagem criado não corresponde ao que a criança tinha imaginado. Como no caso de Therezinha Dantas a quem Lobato prometera colocar um gatinho de estimação, chamado Manchinha, em um livro. O escritor cumpre o prometido na obra $A$ chave do Tamanho, no entanto, pela carta da leitora percebemos que ela se decepciona um pouco com o que acontece a seu gatinho na obra:

"Li seu livro e gostei muito dele. Vi também que o senhor não se esqueceu do meu querido gatinho. Achei-o ‘meio' malvadinho, mas gostei bastante.(...)

Fiquei com pena foi do Manchinha. Ele era tão bonzinho e o senhor o fez comer os pais do Juquinha e da Candoca! Fiquei até zangada com o senhor!”181

O gato mencionado tem em A Chave do Tamanho um papel bastante importante, pois quando Emília muda o tamanho dos seres humanos, transformando-os em seres com o tamanho de formigas, o gato come os pais de duas crianças. Emília então toma conta de Juquinha e Candoca, durante todo o desenrolar da aventura. É claro que Therezinha, que havia pedido a Lobato que incluísse seu gato Manchinha em uma das histórias, não fica muito contente com o papel de vilão que ele desempenha. A chave do Tamanho, como veremos

\footnotetext{
${ }^{180}$ Carta de Gilson Maurity Santos. Rio de Janeiro, 01/04/1943. Biblioteca Monteiro Lobato. Seção de Bibliografia e Documentação. Doc. 997.

${ }^{181}$ Carta de Therezinha Dantas. Rio de Janeiro, provavelmente 1942. IEB/ARAS. Cx 4 P 1 doc 9.
} 
a seguir, foi um dos livros mais comentados pelas crianças, o fato de Lobato ter feito uma reflexão sobre a Guerra Mundial por toda a narrativa tornava o livro menos engraçado, mas na opinião das crianças não menos interessante.

Em toda a correspondência são inúmeras as sugestões oferecidas ao escritor pelas crianças. Idéias essas que, pelo que parece, Lobato levava a sério. Um dos leitores solicita uma história que se passasse na Pré-história:

“A ideia que eu lhe dou, é de escrever um livro fazendo a turma ir a 'pré-historia' onde eles possam encontrar Dinossauros e outros animais de grande porte”"182

Lobato não chega a escrever uma nova aventura com este tema, mas a aborda em um álbum de figurinhas, intitulado Um sonho nas cavernas, lançado pelo café Jardim, em 1943.

Outros leitores, como o menino Márcio de oito anos, escrevem para lembrar Lobato das histórias que ele mesmo havia prometido contar no decorrer de uma determinada aventura:

"Sr. Monteiro Lobato no livro Pena de Papagaio o menino envisível prometera ir com eles no mar dos piratas.

No livro diz que eles ião fazer essa viagem.

Como o sr. não escreveu essa viagem venho pedir lhe que escreva essa viagem onde Pedrinho, Narizinho, Emilha e o Visconde vem com o Peninha ao mar dos piratas.

Vam todos o Visconde, Faz de Conta e o Rabicó

Com Faz de Conta vai acender o fogo e assar Rabicó

Mas com a sabedoria e a astúcia de Peninha e a coragem do bando comseguem rapitar o Faz de conta e Rabicó.

E ao voltar ao sitio prometer ir a Liliput a terra de Gulliver.”183

O menino não só lembra o autor como dá idéias de como desenvolver a narrativa, com seus pontos de tensão: piratas prendem Faz de Conta, boneco de madeira e Rabicó, que são libertados por Peninha e todo bando. Até mesmo sugere a continuação, que seria uma viagem a Liliput. Apesar da linguagem

\footnotetext{
${ }^{182}$ Carta de Eduardo da Silveira Teixeira Leite. Termas de Lindóia, sem data. IEB/ARAS. Cx 1 P 2 doc 4.

${ }^{183}$ Carta de Márcio Moreira Nascimento. São Paulo, 06/09/1943. IEB/ARAS. Cx 1 P 2 doc 46.
} 
utilizada na carta revelar um menino com pouca idade, podemos notar que suas idéias para os livros são bastante aventurescas e cheias de fantasia.

A menina Lucilia prefere aventuras passadas em uma terra distante: a China, onde claro a leitora também seria uma personagem:

“Monteiro Lobato peço que escreva um livro que entre não só Narizinho, Pedrinho, Emilia, O Visconde, o Renoceronte, o burro falante, Da Benta, o “anjinho” e Tia Anastácia como também eu, esta ultima personagem eu peço para entrar num livro que conta uma viagem à china"184

Já a menina Liliana Guimaraens, filha do escritor João Alphonsus de Guimaraens, dá uma idéia ligada ao cotidiano:

“Agora uma idéia. Você nunca fez festa de aniversário nos seus livros. Quero uma festa bem bonita com bolo feito por tia Nastácia.”185

Outros solicitam histórias que explicam os últimos acontecimentos, como na carta escrita por Renato, de dez anos, em dezembro de 1945:

"Eu desejaria que o senhor escrevesse a história da Bomba Atômica, contada pela vovó D. Benta uma das personagens do sítio do Picapau Amarelo.”186

Provavelmente todas essas idéias que Lobato recebia dos leitores eram de fato respostas a pedidos seus feitos através cartas. Como podemos verificar em uma das respostas de Lobato a uma carta escrita por Alariquinho, onde percebemos claramente a solicitação do escritor:

“Faço questão de receber outras cartas do amigo íntimo, dando-me idéias para os meus livros, mas cartas inteirinhas escritas por ele, sem que papai ou mamãe metam o bedelho ou consertem as idéias do amigo. Os amigos íntimos dizem tudo o que pensam e não pedem opinião a ninguém.”187

Trechos como esse deveriam ser freqüentes nas cartas de Lobato às crianças, pois muitas respostas trazem sugestões que em certa medida deviam apontar caminhos para que o escritor escrevesse sua obra.

\footnotetext{
${ }^{184}$ Carta de Lucilia Alves de Carvalho. Rio de Janeiro, sem data. IEB/ARAS. Cx 1 P 3 doc 46.

${ }^{185}$ Carta de Liliana Guimaraens. Belo Horizonte, 08/09/1943. IEB/ARAS. Cx 1 P 2 doc 49.

${ }^{186}$ Carta de Renato Vivacqua. Rio de Janeiro, 31/12/1945. IEB/ARAS. Cx 1 P 3 doc 41

${ }^{187}$ MONTEIRO LOBATO. Cartas Escolhidas. 3. ed. São Paulo:Ed. Brasiliense, 1964. p. 273.
} 


\section{Modos de leitura}

Na correspondência enviada a Lobato temos alguns indícios de como a leitura era realizada no período. Muitas cartas se referem ao primeiro contato com as obras de Lobato terem acontecido, antes mesmo da alfabetização, em uma idade precoce, através da leitura feita em voz alta por familiares. Assim o mundo fantástico de Lobato é primeiro percebido através da fala, da oralidade, o que sem dúvida alterava sua recepção. O fato das obras infantis de Lobato serem construídas sobretudo com base em diálogos, faz com que a oralidade esteja muito presente em sua obra. Podemos imaginar o leitor que em voz alta modula sua fala para cada um dos personagens, dando mais ênfase em algumas palavras, fazendo pausas. Não devemos esquecer que essa forma de leitura pressupunha também um ambiente de sociabilidade: todos reunidos no quarto, antes de dormir, ou então na sala com a presença de adultos que comentavam a obra lida.

A jovem Dirce, normalista, por exemplo, escreve contando sobre como, ainda não sabendo ler, mergulhava no mundo fantástico das histórias do Sítio:

“Desde pequenininha, quando nem ao menos soletrar sabia, já consistia para mim um prazer, quando a noite ouvia embevecida, ao lado da mamãe que lia em voz alta, as historias do célebre Monteiro Lobato. Eu me deleitava com essas historias, e mais tarde, quando já sabia ler, ficava horas e horas, esquecida, com um livro entre as mãos, enquanto meu espírito se transportava para um mundo diferente, para o 'Sítio do Picapau Amarelo'.

A imagem de Monteiro Lobato, fazia parte então de todas as divagações de minha meninice, e muitas e muitas vezes, dediquei-lhe meus pensamentos, considerando-o um gênio, o meu melhor amigo, como também de todas as crianças.

Hoje já cursei o Ginásio, e me acho no curso Pré-Normal, mas, continuo a ser fanática apreciadora de seus livros.”188

${ }^{188}$ Carta de Dirce Souza Miranda. Agudos, 24/11/1944. IEB/ARAS. Cx 4 P 2 doc 28. 
A leitora não é a única a mencionar que entrou em contato com a literatura de Lobato por meio das leituras feitas pela mãe ou mesmo irmãos mais velhos. Algumas cartas relatam que muitas vezes a leitura não era individual e em silêncio, e sim coletiva e oral, quase sempre com a mãe ou então o pai, ou um irmão mais velho que lia. Luis Hildebrando em uma crônica intitulada Dona Aranha e suas seis filhas nos conta um pouco desta prática de leitura:

"Mas a grande felicidade de nossa existência de criança (...) Era quando papai, chegando à noitinha do trabalho, sacudia no ar um pequeno pacote.

- Adivinhem o que trago aqui?

Adivinhávamos na hora e era aquela gritaria geral: um novo livro de Monteiro Lobato! Era um verdadeiro entusiasmo! Até meu irmão mais velho, que se orgulhava de ler sempre sozinho, não resistia ao acontecimento. Porque sabíamos o que isso queria dizer: duas ou três semanas de leitura de mamãe, capítulo por capítulo, de noite, antes de dormir. (...)

A sessão de leitura se passava depois do jantar. No quarto dos meninos. Nós nos apressávamos para enfiar os pijamas e nos deitar. Nossa irmãzinha vinha se enfiar na cama de meu irmão mais novo, os olhos brilhando de prazer. Os dois na excitação da espera, ficavam se fazendo cócegas e explodindo em acessos de risos, sob protestos do meu irmão mais velho. Mamãe, chegando com o livro os acalmava:

- Se vocês não pararem de rir, não haverá leitura.

Eles paravam pouco a pouco, as mãozinhas sobre a boca para abafar os risos.

E mamãe lia...”189

O prazer da leitura vinha não somente do que estava sendo lido mas, também do contato físico, da intimidade de quem estava escutando com quem estava lendo, na sonoridade da voz que lia, no carinho com que fazia isso. Todo um contexto emocional envolvia o compartilhar da história.

\footnotetext{
${ }^{189}$ HILDEBRANDO, Luis. Dona Aranha e suas seis filhas. In: Crônicas de nossa época. São Paulo: Paz e Terra, 2001. p. 207-208.
} 
Também por isso a leitura de um mesmo livro se repetia muitas vezes, ainda Luis Hildebrando comenta que, na ausência de obras inéditas de Lobato, se recorria à leitura de histórias já conhecidas:

"Havia entretanto longos períodos sem que saíssem novos livros de Monteiro Lobato. Então, a saudade nos invadia. Saudades das histórias. Saudades principalmente da intimidade das noites de leitura em companhia de mamãe, escutando sua voz, seu falar e seu rir, seus suspiros de emoção, seus comentários sobre uma frase de Dona Benta ou sobre um acontecimento da aventura...

Quando a saudade se tornava insuportável, nós as crianças, organizávamos um complô. Na hora do jantar, à mesa, exigíamos numa sinfonia de gritos e lamentações, a leitura de um capítulo já lido, mas de que gostávamos muito. Mamãe resistia um pouco, mas se deixava finalmente convencer. Nessas ocasiões, entretanto, era ela que escolhia o livro e o capítulo e ela selecionava, sem dúvida as passagens que mais apreciava.”190

As cartas de leitores também revelam o quanto essa prática da leitura intensiva estava presente no cotidiano das crianças. O jovem Gilson relembrando a leitura de Lobato quando era criança dizia ler inúmeras vezes, mas sempre como se fosse a primeira:

"Reli inúmeras vezes todos os livros. E cada vez (não sei como conseguia fazer isso) abstinha-me de toda idéia preconcebida e entrava no volume com a mesma delicia da prelibação duma história de Monteiro Lobato - Tal qual da primeira vez.”191

Já Haroldo, de treze anos comenta que a releitura é fruto da facilidade com que lia toda a sua obra:

“(...)Li quando tinha apenas 9 anos a sua "Viagem ao Céu” e achei tão fácil e compreensível a sua maneira de expressão, que reli muitas vezes esse livro.”192

Therezinha Dantas nos conta qual é o seu preferido:

\footnotetext{
${ }^{190}$ HILDEBRANDO, Luis. Dona Aranha e suas seis filhas. In: Crônicas de nossa época. São Paulo: Paz e Terra, 2001. p. 208.

${ }^{191}$ Carta de Gilson Maurity Santos. Rio de Janeiro, 20/03/1943. IEB/ARAS. Cx 4 P 2 doc 53.

${ }^{192}$ Carta de Haroldo Costa. Curitiba, 26/12/1944. IEB/ARAS. CX 2 P 1 doc 37.
} 
“Andei relendo alguns dos seus livros e ainda gostei mais deles. É sempre assim - quanto mais se lê uma qualquer obra mais coisas interessantes lá se acha. "Reinações de Narizinho” eu li umas cinco ou seis vezes!”193

A menina Nicean escreve de Manaus:

“Tenho aprendido muito através de seus belos livros! Já possuo uma biblioteca bem regular e, em minha estante, estão 17 livros seus, que leio e releio com o maior prazer."194

Os leitores comentam pelas cartas que a leitura intensiva era fruto da apreciação das obras de Lobato, eles liam e reliam inúmeras vezes um único livro, pois gostavam desse livro, por seu enredo ser divertido, pela facilidade da leitura e pela compreensão imediata da obra. Diferentemente do que se poderia imaginar, a leitura intensiva não ocorria pela falta de livros, pois muitos leitores comentam ter muitos livros: coleções inteiras de Lobato e de outros autores, mas sim por gostarem e sentirem prazer em cada leitura e releitura. Quase como se visitassem um local do qual gostam muito, ou brincassem repetidas vezes da brincadeira preferida, sem se cansarem com a repetição.

Alguns leitores comentam que a leitura e releitura das obras ocorreu durante o período em que estavam acamados por motivo de doença, como a menina Maria Victoria:

"Eu estava de cachumba e mamãe leu para mim todas as "Reinações". Gostei muito.”195

Ou então Nina Rosa:

“Também gosto de Reinações de Narizinho quando eu li da primeira vez eu estava no hospital pois havia feito operação de apendicite(...)”196

E também Gilbert Hime aproveita para ler, estando impossibilitado de sair da cama:

"Estando de cama ha mais de tres semanas, resolvi passar uma revista nos meus livros.”197

\footnotetext{
${ }^{193}$ Carta de Therezinha Dantas. Rio de Janeiro, sem data. IEB/ARAS. Cx 4 P 1 doc 9.

${ }^{194}$ Carta de Nicean Serrano Telles de Souza. Manaus, 14/04/1941. IEB/ARAS. Cx 1 P 2 doc 34.

${ }^{195}$ Carta de Maria Victoria. Sem local e sem data. IEB/ARAS. Cx 2 P 2 doc 27.

196 Carta de Nina Rosa. Rio de Janeiro, 25/07/1942. IEB/ARAS. Cx 2 P 1 doc 20.

${ }^{197}$ Carta de Gilbert Hime Jr. São Paulo, 15/03/1942. IEB?ARAS. Cx 1 P 1 doc 36.
} 
Vemos então pela documentação que os leitores relatam vários modos de leitura: a leitura coletiva feita principalmente com a presença de um adulto, sendo a mãe a mais citada, a leitura individual realizada nas horas de lazer. Muitos afirmam ler e reler muitas vezes alguns livros, mesmo possuindo muitos exemplares. É interessante que poucos comentam ler a obra de Lobato no ambiente escolar, quando o fazem referem-se principalmente aos contos para adultos, como Negrinha, que aparecem em coletâneas já para o uso do Ginásio. A obra infantil de Lobato parece não ter circulado durante as décadas de 30 e 40, em um âmbito escolar, devemos ter em mente que como alguns colégios proibiram seus livros, ler Lobato para algumas crianças deveria ser quase um ato de rebeldia.

\section{A circulação dos livros}

São principalmente os pais que, tanto nos períodos de doença, como em festas de Natal, de Reis e aniversários, davam de presente aos filhos os livros de Lobato. Pela documentação percebemos como a circulação de livros, durante as décadas de 30 e 40, ainda era precária. São inúmeras as cartas que se queixam por não encontrarem alguns dos livros, ou por estarem os livros com edições esgotadas, escrevem então a Lobato como forma de adquirirem os livros que não são encontrados, como relata Fernando, escrevendo da capital federal:

“Acontece entretanto que não pude ainda completar a coleção de seus trabalhos na minha pequena biblioteca. Papai tem andado em todas as livrarias, e não consegue encontrar, porque está esgotado aqui no Rio, ' $\mathrm{O}$ Picapau Amarelo’, ‘Poço do Visconde’, ‘As aventuras de Hans Staden’, ‘e as Novas Reinações de Narizinho’. Se o senhor com seu prestígio ai em São Paulo, puder me resolver este problema, fico-lhe muito grato.”198 E também Severino, da mesma cidade:

${ }^{198}$ Carta de Fernando César Mergulhão. Rio de Janeiro, sem data. IEB/ARAS. Cx 2 P 2 doc 33. 
"Eu tenho todos os seus livros menos 'Histórias de Tia Nastácia' que eu procuro nas livrarias mas não encontro.” 199

Para conseguir um livro esgotado de Lobato os leitores chegam a escrever a Rádio Globo, do Rio de Janeiro, que transmitia a novela "Narizinho Arrebitado”, como vemos nessa carta, escrita por José Carlos, de doze anos residente em Niterói:

"Sou sincero admirador do snr. Monteiro Lobato, do qual tenho todas as suas obras infantis, com exceção do livro “Memórias de Emília”, que não se encontra, por estar a edição esgotada, nem aqui, nem no Rio.

Ouvindo os capítulos de "Reinações de Narizinho", que me entusiasmam, principalmente pela fidelidade que se observa entre o texto do livro e o da radiofonização, ocorreu-me escrever-lhe, para não só aplaudir o trabalho da RÁDIO GLOBO, como, também, solicitar os seus bons ofícios, afim de que eu possa adquirir o livro que me falta na estante. $^{200}$

A carta citada acima chegou a Lobato porque foi enviada pela Rádio Globo, com um bilhete de Luiz de Toledo Piza onde ele menciona que no Rio de Janeiro a obra Memórias de Emília estava esgotada em todas as livrarias. Percebemos pela leitura das cartas que mesmo pertencendo a uma classe social abastada as crianças não conseguiam comprar os livros de Lobato por estes estarem esgotados em muitas cidades do Brasil. Assim, apesar de Lobato ter reeditado inúmeras vezes seus livros, a documentação mostra-nos que ainda não era o suficiente, que o mercado era muito maior do que a possibilidade de produção.

Essa característica de ser um mercado ainda não totalmente preenchido pode ser explicada pela circulação realmente em âmbito nacional das obras do autor. Pela documentação verificamos que Lobato recebia correspondência de praticamente todos os estados brasileiros. Até mesmo do exterior Lobato recebe algumas poucas cartas, como de Nova York e de Lourenço Marques, antigo nome

\footnotetext{
${ }^{199}$ Carta de Severino de Moura Carneiro Junior. Rio de Janeiro, 13/05/1945. IEB/ARAS. Cx 1 P 3 doc 22.

${ }^{200}$ Carta de José Carlos Quintella. Niterói, 26/06/1945. IEB/ARAS. Cx 1 P 3 doc. 31.
} 
da capital de Moçambique. Um leitor chamado Manuel Pedro, residente em Lourenço Marques escreve a Lobato contando:

“Já tenho 15 livros da colecção de V. Exa., e todos eles me agradam muito inclusive a 'História do mundo para as crianças' que ensina muita coisa que ignorava inteiramente.

É pouco possível compreender como V. Exa. tem tanta imaginação para alguns livros como o 'Sacy' as 'Caçadas de Pedrinho', 'Viagem ao Céu’, ‘As reinações de Narisinho’, o ‘Pó de Pirlimpimpim’ e muitos outros livros.

Ontem acabei o livro de 'Alice no país das Maravilhas', que é muito interessante.

De todos os livros os autores que eu elogio mais são os livros de V. Exa. porque são os que me despertam mais curiosidade.

Quando vou á Minerva central com minha mãi sempre lhe peço para me comprar livros de V. Exa."201

Em Geografia de Dona Benta, Lobato faz alusão a esse leitor quando descreve Emília olhando pela luneta para o continente africano:

“- Agora estou vendo a cidade de Lourenço Marques cheia de portugueses. Há lá uma farmácia; dentro da farmácia está um menino lendo um livro... Imaginem que livro é? A minha gramática!...Oh, esse menino conhece todos os nossos livros. Estou vendo na estante dele as 'Reinações’, as ' Caçadas de Pedrinho', a 'Viagem ao Céu'...”202

Pela correspondência podemos notar que a divulgação e a circulação das obras de Lobato era de fato bastante expressiva. Pois mostra que mesmo em locais, onde não imaginávamos que as obras pudessem chegar, como no continente africano, temos leitores que chegam a ter inúmeros volumes do autor. Isso mostra que não era uma única obra do escritor que havia conseguido atravessar fronteiras, mas sim que havia uma comercialização muito ampla de suas obras.

Como as aventuras passadas no Sítio do Picapau Amarelo eram vendidas em formatos seriados, Os doze trabalhos de Hércules, por exemplo, saíram

\footnotetext{
${ }^{201}$ Carta de Manuel Pedro O. Marques. Lourenço Marques (Atual Maputo) Moçambique, sem data. IEB/ARAS. CX 1 P 1 doc 4.

${ }^{202}$ MONTEIRO LOBATO. Geografia de Dona Benta. 8. ed. São Paulo: Ed. Brasiliense, 1957. p. 219.
} 
primeiramente em uma série de doze livros, cada qual com uma aventura. Era muito frustrante para os leitores encontrar e ler o início de uma aventura e não ter acesso ao seu final. A leitora Amarílis, de apenas oito anos, solicita a Lobato que não publique mais livros seriados:

"Vou lhe pedir uma coisa: para o senhor não escrever mais livros em continuação. Porque eu fico com vontade de ler o resto mas as vezes eu não acho a continuação",203

A documentação trabalhada também nos revela que os leitores não podiam contar com uma rede de bibliotecas públicas e que as bibliotecas escolares eram pobres e desprovidas de livros. São mais de 15 cartas que solicitam ao autor uma doação de livros para a biblioteca da escola, e outras 33 cartas são escritas em nome de "Clubes de Leituras". Pela leitura das cartas verificamos que esses “Clubes de Leitura” faziam parte do programa de ensino primário e eram organizados pelas próprias crianças orientadas pela professora, sendo mais freqüentes nas $3^{\mathrm{a}}$, $4^{\mathrm{a}}$ e $5^{\mathrm{a}}$ séries do Grupo Escolar. A documentação sugere que eram as crianças que deveriam prover esse "Clube” de livros, elegiam um patrono e faziam reuniões semanais, provavelmente, para emprestarem os livros entre si. Esses livros tinham uma estante especial na sala de aula, onde também eram guardadas fotos e biografias dos escritores. Nas cartas escritas pelos "Clubes de Leitura” Lobato é convidado para ser patrono, e as crianças pedem uma fotografia sua assim como também alguns livros de sua autoria. Pelas cartas enviadas na seqüência notamos que Lobato deveria atender a todos os pedidos, enviando além de um retrato autografado alguns exemplares de seus livros. De todo o conjunto de cartas enviadas pelos “Clubes de Leitura” somente três não são mineiras, sendo duas de Niterói e uma do Distrito Federal. Essa grande maioria de cartas vindas do Estado de Minas Gerais se deve provavelmente ao fato de tais clubes serem previstos no programa de ensino primário de Minas Gerais, de $1927 .{ }^{204}$ Como já foi citado algumas cartas comentam o uso das bibliotecas escolares, contudo, as

\footnotetext{
${ }^{203}$ Carta de Amarílis Rocha de Cunto. Pelotas, 06/11/1941. IEB/ARAS. Cx 2 P 1 doc 14.

${ }^{204}$ KLINKE, Karina. A leitura no curso primário e o movimento escolanovista em Minas Gerais. Disponível em: http://www.anped.org.br/reunioes/23/textos/0204p.PDF. Acesso 10.02.2008.
} 
cartas nos informam que as bibliotecas haviam sido desfalcadas, ou tinham poucos volume desinteressantes sendo por esse motivo pouco frequentadas. Assim na ausência de bibliotecas adequadas os leitores deveriam recorrer às práticas difundidas entre todas as classes sociais, como a do empréstimo de livros.

Mesmo com a falta de uma rede de bibliotecas públicas e escolares eficientes, pela correspondência, percebemos que a leitura das obras de Lobato era uma prática que poderia ser encontrada em todas as classes sociais. Apesar da insuficiência de escolas primárias e secundárias e do grande número de analfabetos, existiam crianças de extratos mais humildes da população que se interessavam pela leitura dos livros de Lobato. Sendo que algumas delas chegavam até mesmo a se corresponder com o escritor, solicitando livros, conselhos e até mesmo oportunidades de trabalho. Um dos leitores, Celso Bentim escreve descrevendo uma cena vista da janela da pensão onde morava em São Paulo:

"Hoje presenciei um quadro muito curioso: Um menino, de seus onze anos, passou, quando eu estava na janela, em frente a casa. Era, naturalmente, filho de lavadeira, por ter uma ‘trocha' de roupa sobre a cabeça. Um outro menino encontrou-se com ele e pararam bem a janela onde eu estava. Só naquele momento é que vi carregar, na mão direita, o filho da lavadeira, um livro de Monteiro Lobato. O menino que encontrou-se com ele pediu o livro para ver. Chamei um colega para presenciar aquilo. Ambos não nos via. O livro era Gramática da Emília; vi pelo desenho, pois o outro folheava, ser, se não me engano, da autoria do mesmo pintor que desenhou as figuras do Poço do Visconde. Como sempre costumo pensar sobre o que vejo, veio-me a idéia mil coisas sobre aquele menino.

Pouco depois ele foi embora, o outro seguiu o seu caminho. Fiquei com vontade de saber o nome do filho da lavadeira para guardá-lo; acho que daqui uns vinte anos vê-lo-ia em alguma livraria. O senhor ficaria admirado se presenciasse aquele quadro.,205

A surpresa mencionada pelo leitor, de ver um livro de Lobato nas mãos de um filho de lavadeira, se devia, provavelmente, ao fato das lavadeiras serem

${ }^{205}$ Carta de Celso Bentim. São Paulo, 29/08/1944. IEB/ARAS. Cx 4 P 2 doc 13. 
provenientes das camadas mais humildes da cidade. Logo, não seria usual um livro nas mãos de crianças tão desprovidas de recursos. Contudo, percebemos pela documentação pesquisada, que muitas crianças que escreviam a Lobato não tinham recursos para comprarem muitos de seus livros, mas os liam por intermédio de empréstimo de amigos ou parentes. Como pode ser visto na carta de Maria Helena:

“(...)Snr. Monteiro Lobato, peço-lhe um grande favor, se o senhor pode mandar-me alguns livros de sua autoria, porque sou pobre, minha mãe é empregada e mal dá para vestir-nos, não posso comprar.

Já li alguns livros do Snr. como: Geografia de D. Benta (eu tenho) Viagem ao Céu - Emilia no Pais da Gramática - Robinson Crusoé - Peter Pan Alice no Pais das Maravilhas - Contos de Andersen - Aventuras do Barão de Munchausen.,206

Ou ainda de leitores que emprestam seus livros a outras crianças, como Nice Viegas:

"Estando a conversar com um seu admirador, e sabendo ele que eu possuo toda a coleção adorada pelas crianças, pediu-me um dos livros emprestado; ao perguntar-lhe qual preferia, ele me respondeu: Qualquer um, basta ser escrito por Monteiro Lobato.”207

O empréstimo de obras era, por vezes, necessário mesmo em uma classe mais abastada devido ao fato de as obras se esgotarem facilmente, e uma nova edição demorar a chegar as prateleiras. Assim, o empréstimo de obras deveria ser uma prática bastante comum pela dificuldade na aquisição, independente das classes sociais.

Podemos também notar como essa prática - de empréstimo de obras literárias de Lobato - deve ter sido comum, por outros registros, como no interessante conto Felicidade Clandestina, de Clarice Lispector. Nele a autora nos conta o sofrimento que passou nas mãos de uma menina, filha do dono de uma livraria, que tinha livros, em especial possuía Reinações de Narizinho, e com a promessa de emprestá-lo, torturava Clarice sempre inventando um motivo para não emprestá-lo:

\footnotetext{
${ }^{206}$ Carta de Maria Helena. Guaxupé, 25/01/1946. IEB/ARAS. CX 1 P 3 doc 42.

${ }^{207}$ Carta de Nice M. Viegas. Maceió, 03/03/1939. IEB/ARAS. Cx 1 P 2 doc 25.
} 
“(...) Na minha ânsia de ler, eu nem notava as humilhações a que ela me submetia: continuava a implorar-lhe emprestados os livros que ela não lia. Até que veio para ela o magno dia de começar a exercer sobre mim uma tortura chinesa. Como casualmente, informou-me que possuía As reinações de Narizinho, de Monteiro Lobato. Era um livro grosso, meu Deus, era um livro para se ficar vivendo com ele, comendo-o, dormindo-o. E, completamente acima de minhas posses. Disse-me que eu passasse pela sua casa no dia seguinte e que ela o emprestaria."208

No conto, Clarice Lispector, nos revela a crueldade da menina rica em se utilizar do livro para torturar a amiga, sempre adiando o empréstimo, mas também revela o amor, quase sensual de ter o livro, quando finalmente por intermédio da mãe da menina ela consegue o livro tão cobiçado. O conto nos mostra como ter o livro era também algo desejado, a sua materialidade do livro, o toque nas páginas e a grossura do volume, tudo era sentido e dava à leitura um significado maior. Como Clarice nos diz: “Às vezes sentava-me na rede, balançando-me com o livro aberto no colo, sem tocá-lo, em êxtase puríssimo. Não era mais uma menina com um livro: era uma mulher com o seu amante."209

\section{A materialidade do livro}

Em muitas cartas enviadas a Lobato, as crianças, tecem comentários sobre o aspecto material dos livros, referem-se aos formatos utilizados na publicação e aos ilustradores. No período pesquisado temos de ressaltar que as edições das obras de Lobato não eram padronizadas e, às vezes, dentro de uma mesma coleção temos a utilização de tamanhos e ilustradores diferentes. Essa característica provavelmente fazia com que os leitores não pudessem visualizar um padrão na coleção. Assim, muitas cartas reclamavam, ou faziam sugestões no sentido de deixar as coleções mais uniformes, como Cordélia, de catorze anos, que solicita ao autor ajuda para conseguir os exemplares no antigo formato:

\footnotetext{
${ }^{208}$ LISPECTOR, Clarice. Felicidade Clandestina. Rio de Janeiro: Ed. Rocco, 1998.

${ }^{209}$ Idem.
} 
"Eu possuo quase todos os livros de autoria do Sr., pertencentes à 'Série $1^{\mathrm{a}}$ da Biblioteca Pedagógica Brasileira'.

Até poucos dias faltavam-me apenas estes: 'As aventuras de Hans Staden’, ‘As caçadas de Pedrinho’, 'Peter Pan’, 'D. Quixote das Crianças’, 'O Poço do Visconde’ e ‘A Chave do Tamanho'.

Eu, entretanto, já adquiri ‘A Chave do Tamanho' e 'Caçadas de Pedrinho’. Achei-os interessantíssimos e muito engraçados, mas - para dizer a verdade- eu não gostei muito do formato desta última edição de ‘Caçadas de Pedrinho’. (5 edição)

Passados alguns dias, quis comprar as 'Aventuras de Hans Staden' e 'Peter Pan'; Entretanto, percorri todas as livrarias da cidade, e disseramme que estes livros estão esgotados.

Com certeza na próxima edição destes dois livros, os volumes terão o mesmo formato de 'Caçadas de Pedrinho' na 5a edição (18 cmX24,5 cm), não é verdade?

Como eu queria ter estes livros no formato antigo. (15,5cms X 21,5 $\mathrm{cm})$, vou pedir-lhe um favor:

Será que o Sr. tem e pode ceder-me um exemplar de 'Peter Pan’ e outro de 'As aventuras de Hans Staden', no antigo formato?

Peço-lhe o favor de me escrever dizendo si é possível.

Si o Sr. cedê-los, pode me enviá-los e dizer quanto é que eu lhe remeterei o dinheiro.

Ficar-lhe-ei muito grata."210

Como vemos pelo pedido da leitora, existia uma preocupação com a materialidade do livro, era importante para ela que a coleção tivesse uma uniformidade, pois como ela comenta na carta seguinte ela tinha um local bastante específico para guardar seus livros, que não deveriam ser poucos:

“Agradeço-lhe também os elogios que me fez e, modéstia à parte, gosto mesmo de ter os meus livros muito em ordem. Até já organizei um catálogo, no qual aparece o nome do livro, o nome do

${ }^{210}$ Carta de Cordélia Fontainha Seta. Belo Horizonte, 15/02/1944. IEB/ARAS. Cx 1 P 3 doc 2. 
autor, o número do volume na prateleira, o número das prateleiras na estante, e o preço do volume.

Tenho muita vontade de ir conhecer a sua biblioteca. Assim como Narizinho acha que a Emília é 'espirro de Gente’, eu acho que a minha biblioteca deve ser 'espirro de biblioteca'. (Será espirro da sua biblioteca?)"211

Além do formato dos livros chamarem a atenção das crianças, outro aspecto comentado são os ilustradores das obras de Lobato. Nas poucas cartas que se referem às ilustrações as crianças tecem comentários ou reclamações, sobre um ou outro ilustrador. O menino Severino faz uma crítica veemente a Rodolfo:

"Para uma coisa eu quero lhe chamar a atenção: Há um desenhista chamado Rodolfo que faz verdadeiros aleigões. Ele faz Dona Benta feia, Tia Nastácia toda desajeitada, o Visconde nem parece o Visconde, Emilia uma coisa horrorosa, Pedrinho e Narizinho nem se fala. Eu gosto do outro desenhista chamado Belmonte que faz desenhos muito bonitos.”212

Enquanto que Lucília elogia Belmonte:

“Gostei muito das ilustrações de Belmonte (já as conhecia da Gazeta infantil) e acho que o senhor deve dar todos os livros para ele ilustrar."213

Assim como Ângelo, que apesar de gostar dos desenhos de Belmonte, tem uma preferência especial por J. U. Campos:

"E por falar nisso, por onde anda o Belmonte? Os desenhos de J. U. Campos são melhores. A Emília do Campos é graciosa!

A Emília é muito bem desenhada! O Pedrinho é ótimo! Dona Benta idem! O J. U. Campos é um bom desenhista, mas o Belmonte não fica atrás não!

O Belmonte é uma espécie de caricaturista, como na 'Aritmética da Emília’, e ‘Emília no país da Gramática’, que são bons desenhos. Eis

\footnotetext{
${ }^{211}$ Carta de Cordélia Fontainha Seta. Belo Horizonte, 13/04/1944. IEB/ARAS. Cx 1 P 3 doc 3.

${ }^{212}$ Carta de Severino de Moura Carneiro Junior. Rio de Janeiro, 19/02/1945. IEB/ARAS. Cx 1 P 3 doc 21.

${ }^{213}$ Carta de Lucília A. Carvalho. Rio de Janeiro, sem data. IEB/ARAS. Cx 1 P 3 doc 47.
} 
minha impressão dos desenhistas. Eu quando for escritor, e tradutor, meu desenhista vai ser o Campos."214

Para Edite tanto Belmonte como Rodolfo são ótimos desenhistas:

“(...) os ensinamentos ali contidos são inúmeros; as piadas não só da

Emilia como dos outros, são muito engraçadas; os desenhos de Belmonte e de Rodolfo estão ótimos.”215

Percebemos por esses trechos que os desenhos de Belmonte são muito apreciados, assim como os de J. U. Campos. Mas enquanto o primeiro leitor, Severino, desaconselha ao escritor o uso dos desenhos de Rodolpho, por serem desproporcionais, feios e não representarem fielmente os personagens, todos concordam ser Belmonte um bom desenhista. Quando lemos a opinião de Ângelo vemos que este já possuía um olhar mais especializado, pois ele qualificava os desenhos de Belmonte de caricaturas. Talvez essa opinião fosse também fruto do conhecimento que a criança tinha do trabalho que Belmonte fazia para revistas e jornais, como no caso do célebre Juca Pato. Entretanto, percebe-se pela documentação que não existe unanimidade na opinião sobre os ilustradores, pois enquanto uns detestam os desenhos de Rodolfo outros elogiam, dizendo estar ótimos.

As ilustrações também são comentadas em duas cartas que apontam os erros cometidos, nos livros de Lobato, como na obra Minotauro e em um livro de Viriato Corrêa. No entanto, essas cartas mostram que são adultos que verificam os erros. Sobre a obra Minotauro, um leitor, Dr. H. E. Schroeder comenta que o ilustrador errou ao fazer um tripopo, com quatro pés ${ }^{216}$. Enquanto que na carta sobre a obra de Viriato, Meu Torreão, é o pai que alerta à leitora que o cacho de bananas estava em posição errada ${ }^{217}$.

\section{As crianças comentam a obra de Lobato}

O aspecto principal presente em praticamente todas as cartas pesquisadas é a recepção da obra de Lobato. Pela leitura das cartas percebemos quais eram as

\footnotetext{
${ }^{214}$ Carta de Ângelo Castro. Rio de Janeiro, 07/03/1944. IEB/ARAS. Cx 1 P 3 doc 10.

${ }^{215}$ Carta de Edite Canto. Botucatu, 12/12/1939. IEB/ARAS. Cx 1 P 2 doc. 15.

${ }^{216}$ Carta de H. E. Schroeder. Diamantina, 09/06/1942. IEB/ARAS. Cx 4 P 1 doc 10.

${ }^{217}$ Carta de Beatriz I. S. Birnfeld. Pelotas, 22/12/1936. IEB/ARAS. Cx 1 P 1 doc 54.
} 
características que levaram a obra de Lobato ser tão difundida, durante as décadas de 30 e 40. Como já dissemos cada uma das cartas enviadas para o escritor trazia ou uma opinião ou uma sugestão diferente, cada qual com sua peculiaridade. Reunir e trabalhar com todas essas informações foi uma tarefa difícil não somente pela quantidade, mas, sobretudo, pelo desejo de não perder nenhum pormenor.

A primeira particularidade, das cartas ao comentarem a obra de Lobato, é a liberdade que os leitores têm em transitar pelo mundo real e o da fantasia. As cartas, por vezes, são escritas diretamente aos personagens, como Emília e Dona Benta, e quando são dirigidas a Lobato frequentemente fazem pedidos e recomendações aos personagens. Como vemos na carta do menino João Eduardo, que como muitos outros pedia para Lobato um pouco do pó mágico inventado por ele:

"Snr. Monteiro Lobato

Eu fiz 8 anos no dia 21 de janeiro.

Já sei ler e gosto muito de ler os seus livros.

O que mais me impressionou foi o que o senhor escreveu sobre o pó mágico de pirlimpimpim. Pedia para me mandar um pouco desse pó.”218

Ou na carta da menina Maria Amélia:

“Caro Snr. Monteiro Lobato

Como vae o Snr?

Tenho lido muitos livros que o senhor tem inventado da Historia de Dona Benta, Tia Nastacia, Pedrinho, Narizinho Arrebitado, Do Visconde de Sabugosa e da Emilia. tenho dado muitas risadas de (suas) asneirinhas da Emilia.

Que quero até perguntar ao Senhor onde posso encontrar uma Emilia e o Doutor Caramujo para fazel-a falar”219

Ou ainda no convite da menina Cecília:

“Exmo Sr. Dr. Monteiro Lobato

Tendo lido todos os livros da sua Biblioteca de Narisinho arrebitado e admirando todos os personagens mas, não tendo o prazer de

\footnotetext{
${ }^{218}$ Carta de João Eduardo Berquó. Curitiba, 25/05/1936. IEB/ARAS. Cx 1 P 2 doc 13

${ }^{219}$ Carta de Maria Amélia Silveira Melo. Fazenda N. Sra. Da Glória, 08/07/1936. IEB/ARAS. Cx 1 P 1 doc 47.
} 
conhece-los venho por meio desta pedir-lhe a fineza de convida-los em meu nome para virem lanchar comigo no dia do meu anniversario natalicio que será no dia 22 de Novembro. O lanche terá inicio ás cinco horas"220

Essa fantasia era provavelmente estimulada por Lobato, pois nas poucas respostas que temos do escritor para seus leitores vemos que ele também se utilizava de alguns subterfúgios. Como na resposta escrita para o menino Gilson pelo próprio Visconde de Sabugosa. ${ }^{221}$ Também percebemos o uso do imaginário do Sítio pelo escritor em algumas cartas das crianças, como nas cartas de Vilma, que quando escreve pela primeira vez ao escritor diz:

“O meu maior desejo é vizitar o sítio do Picapau Amarelo e aranjar umas pílulas falantes porque eu já fiz muitas bonecas que não falam.”222

Quando a menina escreve pela segunda vez, já respondendo a carta de Lobato, que provavelmente prometia enviar as famosas pílulas, ela comenta:

“Quindim ainda não veio e eu não recebi as pílulas falantes.”223

Possivelmente, as cartas enviadas pelas crianças eram muito ricas neste jogo de faz de conta, não somente por terem sido escritas por alguém de tão pouca idade, mas também devido às características inerentes à obra de Lobato. No início de sua produção, o escritor, ainda utilizava o sonho como forma de passagem do mundo onírico, da fantasia ao mundo real dos personagens. Nas primeiras versões de Narizinho Arrebitado, Lobato, terminava a história como se a aventura no Reino das Águas Claras fosse somente um sonho. Com as modificações feitas nas edições que se sucederam, aos poucos, o autor assume o mundo da fantasia como real, possibilitando aos leitores a crença nesse universo criado. Dessa forma, por volta de meados da década de trinta, o autor já não usava mais subterfúgios para criar uma literatura baseada na imaginação. Por exemplo, temos o uso do "faz de conta” de Emília em inúmeras situações como em Os doze trabalhos de Hércules, quando o herói grego está em apuros, pois Emília havia quebrado a ponta de todas as suas flechas, a saída encontrada por Emília é bastante simples, ela diz: “faz de

\footnotetext{
${ }^{220}$ Carta de Cecília de Barros Correia. Rio de Janeiro, 05/10/1933. IEB/ARAS. Cx 1 P 2 doc 1.

${ }^{221}$ DEBUS, Eliane S. D. o Monteiro Lobato e o Leitor esse conhecido. Itajaí; Florianópolis: Univali;UFSC, 2004.

${ }^{222}$ Carta de Vilma Pires. São Paulo, sem data. IEB/ARAS. Cx 1 P 3 doc 13.

${ }^{223}$ Carta de Vilma Pires. São Paulo, 03/10/1944. IEB/ARAS. Cx 1 p 3 doc 14.
} 
conta que essa flecha tem ponta”. Na história imediatamente a flecha adquire ponta e Emília passa a ser considerada uma poderosa feiticeira.

Além disso, Lobato inseria em sua narrativa elementos cotidianos e verídicos, como conversas sobre jogos de futebol entre times paulistanos, comentários sobre as estrelas do cinema norte-americano ou mesmo sobre as safras de café e a economia brasileira. Assim, a criança ao ler as aventuras criadas pelo autor tinha acesso a uma narrativa onde ficção e realidade estavam amalgamadas de tal forma que tudo poderia parecer possível. É necessário, também, lembrar que Monteiro Lobato reescreveu suas histórias inúmeras vezes até elas serem publicadas no formato das obras completas, já na segunda metade da década de 40. Esse trabalho de reedição possibilitou que mesmo histórias publicadas no início de sua produção, na década de 20, fossem coerentes com as obras publicadas posteriormente.

Lobato estabelece de forma tão concreta esse universo fantástico que no início da obra O Picapau Amarelo, ele faz quase que uma profissão de fé:

“(...) Mas o Mundo-da-Fábula não é realmente nenhum mundo de mentira, pois o que existe na imaginação de milhões e milhões de crianças é tão real como as páginas deste livro. O que se dá é que as crianças logo que se transformam em gente grande fingem não mais acreditar no que acreditavam.

- Só acredito no que vejo com meus olhos, cheiro com meu nariz, pego com minhas mãos ou provo com a ponta da minha língua, dizem os adultos - mas não é verdade. Eles acreditam em mil coisas que seus olhos não vêem, nem o nariz cheira, nem os ouvidos ouvem, nem as mãos pegam."224

Sendo assim as cartas das crianças só fazem continuar um jogo proposto pelo próprio autor, onde o “faz de conta” era real e a qualquer momento, Quindim poderia passar na casa de uma leitora levando pílulas falantes para bonecas emudecidas. A fantasia presente nas cartas nem sempre levam a pensar em crianças ainda muito novas, antes parecem falas de um diálogo onde tudo é possível.

${ }^{224}$ MONTEIRO LOBATO. O Picapau Amarelo. 7. ed. São Paulo: Ed. Brasiliense, 1957. p. 3. 
A personagem mais citada em todas as cartas não poderia ser outra que não Emília, a bonequinha de pano é praticamente uma unanimidade. Tanto por parte dos meninos como das meninas, Emília é sempre lembrada como a mais gozada, a que tem as melhores idéias. Talvez o fato de Lobato não ter construído sua obra baseado em diferenças de gênero tenha feito com que os leitores, independentemente do sexo, gostassem das mais variadas obras. Em um primeiro momento pensou-se que livros como Sacy, ou Caçadas de Pedrinho, pudessem interessar mais aos meninos, e livros como Reinações de Narizinho fossem mais lidos por meninas. Contudo, o que a pesquisa com as cartas mostrou é que tanto meninos como meninas referiam-se aos mesmos livros, não tendo sido observado nenhuma preferência maior calcada em diferenças por gênero.

O que notamos na leitura da correspondência é que se não há uma preferência, baseada no gênero, com relação aos livros preferidos, no que diz respeito à identificação do leitor com os personagens ela está presente. As meninas sempre se dizem parecer ou que gostariam de ser a Emília ou Narizinho, e os meninos se identificam com Pedrinho. Com Visconde não há essa identificação, possivelmente pelas desventuras acontecidas, muitas vezes, os leitores pedem a Lobato um pouco mais de compaixão para com esse personagem.

A preferência pela Emília deve-se, sobretudo, pelo seu humor. É a opinião de Leda, de doze anos:

“Já li quasi todos os seus livros, exceto 'História das invenções' e 'Aritmetica da Emilia'

Acho muita graça na Emilia.

Como é que na sua cabeça cabe tanta coisa boa e engraçada?”225 Já Myralda gostaria de morar com a personagem:

“Mas a Emilia é interessante em? Ah! Se eu pudesse morava com a Emilia! Queria rir o dia inteirinho!”226

Enquanto que a menina Evangelina, de nove anos a prefere aos outros personagens:

“De todos os 'picapaus’ o que mais gosto é da Emilia com as suas idéias tão engraçadas.”227

\footnotetext{
${ }^{225}$ Carta de Leda A. R. Maciel. Recife, 04/07/1936. IEB/ARAS. Cx 1 P 1 doc 45.

${ }^{226}$ Carta de Myralda Coragem. Guaxupé, 04/12/1945. IEB/ARAS. Cx 2 P 2 doc 11.
} 
O menino Antonio Henrique, de nove anos diz:

"Como vai a Emilia? Ainda muito asneirenta? Gosto muito dela porque é asneirenta."228

Enquanto que Eduardo, primo de Alariquinho, nos diz:

“(...) desejo que o Sr. continue com todos seus personagens, mas não aperfeiçoe mais a Emilia porque a bonequinha já chegou ao maximo. Não faça que esse Visconde morra e apareça um outro (como já fez em muitos)”229

Às vezes as opiniões não são muito lisonjeiras para com a bonequinha, e tomam o partido do Visconde:

“A Emília sempre tiraninha, cheia de autoridade, faz que a gente pense que na verdade só os imponentes dominam. Não vê o coitadinho do Visconde, com toda a sua ciência, como é maltratado. E agora passou a ser ‘aranha de cartola'. Quase chorei quando ele enlouqueceu. A sua pena precisa ser mais generosa para com o visconde, coitadinho, tudo de ruim acontece para ele! A Emília que é uma diabinha, faz de Hércules gato e sapato. Domina-o. Ele a carrega. Ele a atende. Pobre do nosso viscondinho."230

Outros personagens também são frequentemente citados nas cartas. Dona Benta é considerada uma senhora sábia e justa pelos leitores que se referem a ela. Existe mesmo um leitor, Modesto Marques, que a intitula “pedagoga revolucionária”. Tia Nastácia também aparece na correspondência, mas sempre relacionada a seus quitutes, muitos são os leitores que gostariam de ir ao Sítio para experimentar seu famosos bolinhos.

Em algumas cartas, as crianças, comentam outros personagens que aparecem pontualmente no decorrer da obra de Lobato como o Saci ou o Anjinho da Asa Quebrada. Sobre o Anjinho a leitora Lucília lembra:

\footnotetext{
${ }^{227}$ Carta de Evangelina Barbosa de Morais. Fazenda Sto. Inácio, 11/11/1939. IEB/ARAS. Cx 2 P 1 doc 7.

${ }^{228}$ Carta de Antonio Henrique Abreu Amaral. Santos, 26/07/1945. IEB/ARAS. Cx 2 P 2 doc 2.

${ }^{229}$ Carta de Eduardo da Silveira Teixeira Leite. Termas de Lindóia, sem data. IEB/ARAS. Cx 1 P 2 doc 4.

${ }^{230}$ Carta de Celso Bentim. Curitiba, 12/05/1945. IEB/ARAS. Cx 4 P 2 doc 16.
} 
"Hoje relendo aquele livro Viagem ao céu lembreime que nos livros que fez depois dele não falam no anjinho, não o esqueça é tão engraçadinho!",231

Sobre o Saci o que mais se comenta são suas estripulias, e casos engraçados como o relatado a seguir:

"Bom dia senhor Monteiro Lobato. Sabe, que eu ganhei o seu livro 'Saci’. Já tenho outros mas o Saci é o mais engrasado. Eu me, ri a valer, quando o Saci puxou o cabelo da Yara. Que pena, que a gente nase gente e não Saci."232

O humor aparece em quase todas as referências à obra de Lobato, nas cartas sempre o que é engraçado e diverte é valorizado. São inúmeros os comentários sobre como a leitura dos livros é divertida, como riram a valer com cenas inusitadas, como no comentário de Nina Rosa:

“Também gosto de Reinações de Narizinho quando eu li da primeira vez eu estava no hospital pois havia feito operação de apendicite, dei boas gargalhadas no pedaço que $\mathrm{D}$. Benta tinha se sentado no dedo do pássaro Roca.”233

Ou então os leitores criticam os livros do autor onde o humor não aparece tanto:

“Eu li o seu livro 'Reinações de Narizinho', e gostei das respostas da Emília. Depois quando eu ganhei o 'Viagem ao Céu’ gostei mais ainda. E quando chegou a vez do 'História do Mundo para as Crianças', eu não gostei, não tinha graça!”234

Em um primeiro momento poderíamos pensar que os livros criados por Lobato para auxiliar nos estudos como: Emilia no país da gramática, Aritmética da Emília, Geografia de Dona Benta, História do Mundo para Crianças e Serões de Dona Benta, pudessem ser enfadonhos, pois à temática relacionada a escola

\footnotetext{
${ }^{231}$ Carta de Lucília A. Carvalho. Rio de Janeiro, sem data. IEB/ARAS. Cx 1 P 3 doc 47.

${ }^{232}$ Carta de Flavio Lange de Morretes. Sem local e sem data. IEB/ARAS. Cx 1 P 2 doc 31.

${ }^{233}$ Carta de Nina Rosa. Rio de Janeiro, 25/07/1942. IEB/ARAS. Cx 2 P 1 doc 20.

${ }^{234}$ Carta de Arnaldo Teixeira Mendes. São Paulo, 29/09/1944. IEB/ARAS. Cx 1 P 3 doc 12.
} 
poderia não interessar. Ou ainda porque algumas dessas obras eram adaptações de obras publicadas para a infância nos Estados Unidos da América do Norte. No entanto, as cartas nos mostram que, com pouquíssimas exceções, as crianças adoravam e entendiam melhor as matérias escolares por meio dos livros de Lobato. Um dos fatores que colaboravam nesta aquisição de novos conhecimentos era o humor, assim, as asneiras da Emília faziam com que as crianças dessem boas risadas enquanto aprendiam a gramática, ou que partindo melancias pudessem compreender melhor frações. Muitos são os comentários agradecendo a Lobato por ter escrito tais obras. Como Wanda, que salientava a facilidade com que o autor explicava assuntos de difícil compreensão, além do humor com que escrevia:

\section{"Sr. Monteiro Lobato}

Acabo de ler o seu livro ‘Emilia no País da Gramática’ e venho por meio desta agradecer ao Sr. o muito que aprendi com ele.

Já li 5 livros seus e cada vez gosto mais de lê-los porque sempre aprendo alguma coisa.

O Sr. tem um modo simples de dizer as coisas difíceis que elas se tornam logo fáceis.

Acho tanta graça da Emilia que quando estou lendo dou boas risadas.,235

Da mesma forma Lea, de treze anos comenta:

“(...) devo dizer-vos quanto tem sido úteis os vossos livros, que me têm muitas vezes tirado de sérias dificuldades. Frequentemente quebro a cabeça estudando lições que não há meios de assimilar.

Acontece que depois de algum tempo, tenho a oportunidade de encontrar em alguns livros de vossa autoria o assunto que tanto me torturava e num instante encontro a chave do problema.”236

Em algumas cartas percebemos os livros de Lobato que explicavam uma determinada matéria escolar eram considerados, pelos leitores, superiores aos livros utilizados nas escolas. Como explica Fernando:

\footnotetext{
${ }^{235}$ Carta de Wanda Cortez. Juiz de Fora, 22/02/1945. IEB/ARAS. Cx 1 P 3 doc. 26.

${ }^{236}$ Carta de Lea de Siqueira Prazeres. Maceió, 11/07/1943. IEB/ARAS. Cx 2 p 1 doc. 22.
} 
“Tenho pelo senhor uma grande estima, porque suas histórias, bonitas e instrutivas, muito teêm influenciado nos meus estudos. Fique o senhor sabendo que talvez eu tenha aprendido mais nos seus livros do que naqueles que usam no colégio.”237

Da mesma forma o menino Haroldo, de treze anos, diz:

“O que a minha mãe quebrou a cabeça, sem que ela nunca pudesse entender, eu entendi em dois tempos.

Á sua custa a criançada do meu tempo pode ilustrar-se mais do que os adultos modernos e antigos.

Um tio meu me disse que só há um modo canja de apreender gramática: é ler ‘Emília no País da Gramática’.”238

O ambiente escolar e as aulas, repetidas vezes, recebem adjetivos pouco lisonjeiros, como na carta de Lincoln, que surpreendentemente escreve em nome da classe, dando o endereço da escola para a correspondência:

"Tive a honra de ser o escolhido pelos meus collegas para dirigirlhe esta cartinha que conten o mais sincero de todos os pedidos.

Queremos o seu retrato para pormos num quadro e colocal-o em frente a nossa bibliotheca. o snr. foi reeleito para ser o nosso patrono. Acompanhando o retrato, queremos alguns dados da sua vida, principalmente da sua infancia, de seus brinquedos e estudos preferidos.

Guardaremos tudo isto como reliquia do melhor amigo que tivemos, que nos livrou das cacetes e antigas aulas de Portuguez e Arithimetica.

Os seus livros nós já os conhecemos. O preferido por nós é “Arithmetica da Emilia”, que viajando, comendo melancias nos ensinou fracções. Era este ponto detestado por nós.”239

Todas essas citações nos revelam alguns pontos interessantes a serem analisados. Um deles, comum em várias cartas, refere-se ao ambiente escolar: os livros escolares como algo enfadonho, pesado, em contraposição à literatura de Lobato, que mesmo abordando assuntos escolares era considerada por seus

\footnotetext{
${ }^{237}$ Carta de Fernando César Mergulhão. Rio de Janeiro, sem data. IEB/ARAS. Cx 2 P 2 doc. 33.

${ }^{238}$ Carta de Haroldo Costa. IEB/ARAS. Curitiba, 26/12/1944. Cx 2 P 1 doc. 37.

${ }^{239}$ Carta de Lincoln Geraldo de Féo. Cidade do Prata, MG. 15/05/1936. IEB/ARAS. Cx 1 P 2 doc. 12.
} 
leitores, como agradável, leve, fácil e divertida. Outro ponto a ser analisado é que as crianças se referem à opinião que os adultos têm sobre a obra de Lobato. Professores usam seus livros em sala de aula, pais e familiares também acreditam que as obras facilitam o aprendizado, por isso aprovavam e estimulavam as crianças a lerem essas obras e a se corresponderem com o escritor. As próprias crianças afirmavam que teriam mais conhecimento que as crianças do passado, que não possuíam obras como aquelas.

Assim como diversas crianças escrevem agradecendo a ajuda nas tarefas escolares, comunicando que foram bem em provas por causa de seus livros, elas também escrevem solicitando que Lobato escreva outras obras que abordem alguns assuntos escolares, como ciências ou história do Brasil. Algumas cartas dizem detestar determinado conteúdo, como Sarah, que acha História do Brasil, "muito cacete":

"Estou estudando a Historia do Brasil e como acho muito cacete, peço por favor que o senhor escreva, um livro, sobre este assunto.

Acho que o senhor não quer escrever porque Viriato Corrêa plagiou dos seus contos, escrevendo logo a Historia do Brasil.

Mas por mim pode escrever porque certamente já o tinha imaginado e mesmo eu não gosto dos livros que Viriato Corrêa faz. Prefiro os seus.

Já li quase todos os seus livros achando muita graça e gostando muito.”240

Outras cartas solicitam que Lobato escreva um livro justamente por gostarem muito de uma determinada matéria, e um livro com a Emília explicando facilitaria muito a vida escolar:

"Envio-lhe esta, para pedir que escreva um livro tratando de ciências, incluindo nele a Emilia, o Visconde, Narizinho, Pedrinho, tia Nastácia, D. Benta.

Estou no terceiro ano ginasial e gosto muito desta matéria.

Ai ocorreu-me a idéia de lhe escrever, porque com os seus livros, aprende-se brincando!

É duro decorar aqueles nomes de músculos, tecidos, etc.

\footnotetext{
${ }^{240}$ Carta de Sarah Viegas da Motta Lima. Rio de Janeiro, 18/05/1937. IEB/ARAS. Cx 1 P 2 doc 23.
} 
Mas, com um livro ‘da Emilia’, quem não aprende?

Por exemplo, fiquei maravilhado ao ler 'Historia do Mundo para crianças', 'Geografia de d. Benta', 'Emilia no pais da gramática’, ‘Aritmética da Emilia’ e outros.”241

Além de comentários como os de Sarah comparando a produção de Lobato com a de Viriato Correa serem raros na documentação pesquisada, em muitas cartas os leitores comentam que Lobato é seu autor preferido. Somente alguns autores infantis brasileiros também são comentados pela correspondência, como Malba Tahan e Érico Veríssimo:

“Mas agora, falemos do autor. Este, para mim é o melhor. O modo de escrever, o agrado da leitura, as asneiras da Emília, tudo enfim, para mim é o ‘suco’ (como diz Narizinho) Suas obras infantis, são as melhores para mim. O Sr. e Malba Tahan, formam uma dupla do barulho.”242

“Tenho 7 anos (..) mas já li muitos livros do senhor e achei que o senhor é um grande escritor. Já li: Reinações de Narizinho, As caçadas de Pedrinho e Viagem ao Céu. Já li uns livros de Lewis Carrol de Erico Veríssimo mas achei que os livros do senhor são melhores.”243

Sobre os autores preferidos pelas crianças temos também como fonte de pesquisa o jornal “A Voz da Infância” escrito e publicado pelas crianças frequentadoras da Biblioteca Infantil Municipal, em São Paulo. O jornal tinha publicação mensal e em uma das seções, eram divulgados os números de empréstimos feitos a cada mês. Lobato aparece em todos os meses, assim como também os livros ilustrados de Disney. Somente um outro autor era páreo para Lobato superando-o em alguns meses, o autor alemão Karl May, muito lido por suas aventuras cheias de bravura e heroísmo como Winnetou.

Uma carta enviada pela secretária do jornal, Ligia Busch a Lobato dá conta desta “competição” entre autores na Biblioteca Infantil:

\footnotetext{
${ }^{241}$ Carta de Sylvio. São Paulo, 23/04/1946. IEB/ARAS. Cx 2 P 2 doc 22.

242 Carta de Ângelo Castro. Rio de Janeiro, 07/03/1944. IEB/ARAS. Cx 1 P 3 doc 10.

${ }^{243}$ Carta de Amarílis Rocha de Cunto. Pelotas, 17/09/1941. IEB/ARAS. Cx 2 P 1 doc 13.
} 
"Bendigo a hora em que acertei o cargo de Secretária da 'Voz da Infância’ pois só assim teria a grande honra de receber uma carta do genial escritor Monteiro Lobato.

Sim, senhor, seu gênio creador de enredos tão empolgantes que deliciam o nosso espírito de crianças, jamais será vencido por outro escritor nacional ou estrangeiro. E, embora, Karl May, o derrote em alguns meses, quanto à preferência dos leitores da nossa acolhedora Biblioteca Infantil, é sempre o querido e popularíssimo Monteiro Lobato quem vence longe...."244

Além do humor, outro motivo apontado nas cartas para essa predileção por Lobato deve-se à fluidez da leitura de seus livros. As crianças leitoras comentam em muitos momentos quão fácil é ler seus livros:

"Venho por meio desta exprimir-vos a minha grande admiração pela sua brilhante série de livros infantis. Sou também criança e posso affirmar-vos que dentre as melhores obras infantis, nacionaes e extrangeiras, que já li, as vossas ganham em supremacia sobre as outras. São bons mesmo seus livros ‘seu’ Lobato.

O senhor póde orgulhar-se do que digo, pois estou certo de que correspondo aos mesmos pensamentos de seus milhares de leitores desse nosso caro Brasil. O Brasil é pobre em autores infantis, mas só o senhor vale por muitos. Quem lê seus livros guarda sempre uma agradavel impressão sobre eles, porquê não são como muitos cuja leitura é fastidiosa a gente, principalmente quando estamos nos primeiros passos da leitura." 245

A opinião que o leitor emite sobre a fluidez com que lê os livros de Lobato é de fato resultado de um projeto literário do autor quando escreve para crianças. Em inúmeros momentos, principalmente na correspondência trocada com o amigo Rangel, Lobato afirma que era necessário, ao escrever para as crianças, retirar tudo o que poderia ser chamado de literatura. Comentando a obra de Maria José Dupré, Éramos Seis, ao amigo ele diz:

"Revelou-me um tremendo segredo: o certo em literatura é escrever com o mínimo possível de literatura! Certo, porque desse modo somos lidos,

\footnotetext{
${ }^{244}$ Carta de Ligia Silva Kuntz Busch. São Paulo, 23/09/1943. IEB/ARAS. Cx 4 P 1 doc 19.

${ }^{245}$ Carta de Haroldo Leite. Pedregulho, 02/11/1934. IEB/ARAS. Cx 1 P 1 doc 24.
} 
como ela está sendo e como eu consegui ser nos livros em que me limpei de toda a 'literatura'.(...)

Faltou-me naquele tempo uma Dupré mas a mim me salvaram as crianças. De tanto escrever para elas, simplifiquei-me, aproximei-me do certo (...)" 246

Nesta citação percebemos que a escolha por uma linguagem mais limpa e direta é motivada, em grande medida, pela vontade do autor de ser lido. A lição de Dupré deve ser aprendida para que os literatos possam ser lidos por uma grande parcela da população, para que possam em fim ter um papel de relevo na sociedade, para que possam transmitir suas idéias e transformar a realidade.

No entanto, em outra carta a Rangel, Lobato comenta que para atingir esse objetivo é necessário um trabalho árduo:

"Não imaginas a minha luta para extirpar a literatura dos meus livros infantis. A cada revisão nova nas novas edições, mato, como quem mata pulgas, todas as 'literaturas' que ainda a estragam. Assim fiz no Hércules, e na segunda edição deixa-lo-ei ainda menos literário do que está. Depois da primeira edição é que faço a caçada das pulgas - e quantas encontro, meu Deus!”247

A linguagem é apontada pelos leitores como uma das características mais importantes da obra de Lobato, contudo as crianças não deixam de apontar que a criatividade e as idéias surpreendentes do autor motivam a leitura, fazem com que elas aguardem ansiosamente novas histórias. Assim, ao ler as cartas enviadas pelas crianças vemos que o sucesso de Lobato foi motivado em parte pelo uso de uma linguagem direta, sem tantos floreios, e também ao ritmo rápido, com idéias e sugestões divertidas e insólitas por parte principalmente de Emília. Muitos leitores comentam como ficam envolvidos pela leitura dos livros, sobre o prazer que sentem ao fazê-lo, e se admiram com os enredos, como comenta Manuel Pedro:

“É pouco possível compreender como V. Exa. tem tanta imaginação para alguns livros como o 'Sacy' as 'Caçadas de Pedrinho,

\footnotetext{
${ }^{246}$ MONTEIRO LOBATO. A Barca de Gleyre. 8. ed. São Paulo: Ed. Brasiliense, 1957. p. 340.

${ }^{247}$ Idem. p. 372.
} 
Viagem ao Céu, ‘As reinações de Narisinho’, o Pó de Pirlimpimpim e muitos outros livros."248

Ou como ressalta Cordélia:

“ ‘Os Doze Trabalhos de Hércules’, são destes livros (como aliás são todos os que o Sr. escreve) que a gente (...) lê, lê, lê, nunca enjoa de estar lendo, e fica com pena de ter que acabar de ler.

(...) acho que não há nada com o Sítio... Ele é a melhor cousa que já se imaginou no mundo. Acho que não existe nenhuma criança que não gostaria de morar lá. É mesmo 'o suco dos sucos', como dizem os ‘picapáus’”249

Uma das obras que os leitores comentam com detalhes é A Chave do Tamanho, narrativa na qual Emília faz com que os seres humanos diminuam de tamanho, na tentativa de acabar com a Segunda Guerra Mundial, os resultados como se pode prever são desastrosos. Alguns leitores traçam um parecer sobre a obra, a pedido do autor, que muitas vezes enviava para as crianças com quem se correspondia o livro como presente. A carta de Edith Canto é um destes exemplos a leitora recebeu pelo correio três livros enviados por Lobato, A Chave do Tamanho, Fábulas e Viagem ao Céu. Após a leitura de todos responde para o autor comentando cada um deles:

“O caso é que primeiramente eu li 'A chave do tamanho'.

Gostei, gostei muito. Achei extraordinaria a facilidade de adaptação da Emilia. Suas teorias são notaveis!

O raciocinio do livro está perfeito em face da situação tão dificil.,250

Sobre Fábulas e Viagem ao Céu a leitora escreve:

“O que muito me agradou na nova edição das 'Fabulas' foi o comentário do pessoal do sítio. Comentário 'batatal' que dá margem a outros comentários...

Quanto à 'Viagem ao Céu' ficou inda mais interessante depois das muitas modificações sofridas.”

\footnotetext{
${ }^{248}$ Carta de Manuel Pedro O. Marques. Lourenço Marques (atual Maputo) Moçambique. Sem data. IEB/ARAS. CX 1 P 1 doc 4.

${ }^{249}$ Carta de Cordélia Fontainha Seta. Belo Horizonte, 15/02/1944. IEB/ARAS. Cx 1 P 3 doc 2

${ }^{250}$ Carta de Edith Canto. São Paulo, 12/01/1944. IEB/ARAS. Cx 1 P 2 doc. 19.
} 
Percebemos com o comentário de Viagem ao céu que a menina já havia lido uma edição anterior, percebe e aprova as modificações realizadas pelo autor na narrativa.

A menina Marina, de onze anos, pede a amiga Myralda, que já se correspondia com Lobato há meses, o endereço do autor. Escreve então uma primeira carta em janeiro de 1946 solicitando ao autor que lhe enviasse livros, pois como a mãe era empregada doméstica ela não possuía recursos para comprá-los. Pouco tempo depois ela recebe A Chave do Tamanho, que comenta na missiva seguinte:

"Fiquei encantada com a leitura do seu livro, 'A chave do Tamanho’. Até cheguei a pensar que eu tivesse diminuído.

$\mathrm{O}$ que achei mais interessante, foi a igualdade em que as pessoas reduzidas, vivem; de fato o único causado de tantos transtornos em nossa vida é o tamanho. Cheguei mesmo a crer que existissem tais chaves e se não fosse minha mãe explicar-me de que isso é uma fantasia recreativa, alias muito instrutiva, eu estava disposta a ir em procura da mesma. Tive muita pena de D. Benta, pois é uma avó tão admirável, revoltei-me mesmo com a Emília e segui as idéias de Narizinho, que logo desconfiou ser arte dela a redução do tamanho para a exterminação da tão horrível guerra, que tantos transtornos vem causando a humanidade.

Apreciei imenso o vôo nos besouros, mas fiquei com muito medo do Manchinha, da Aranha caranguejeira e do Marques de Rabicó em terem devorado os pais de Candoca e Juquinha e da mulher do coronel Teodorico, mas analisando o caso, conclui que D. Benta, tia Anastácia, O Burro Falante, a Mocha e o Cel. Teodorico votassem para que o tamanho ganhasse, pois quantas crianças devem ter ficado órfãos, eu que não tenho pai, sei quanto é triste a luta pela vida, juntamente com mamãe.”251

Já Amarílis de nove anos faz um comentário bem mais sucinto:

"Escrevo-lhe hoje esta que vai com o fim de levar as impressões do novo livro.

${ }^{251}$ Carta de Marina Helena Dias. Guaxupé, 24/04/1946. IEB/ARAS. Cx 1 P 3 doc 43. 
Vou se bem sincera. Para dizer a verdade, eu gostei muito do livro: A chave do tamanho, mas no fim desde o capitulo: Em Berlim até Kremlin eu não gostei muito, não sei porque. As partes que eu mais gostei foram: Por causa do pinto sura, a viagem pelo jardim e aventuras.”252

Na obra A Chave do Tamanho o que mais chama a atenção dos leitores é como Emília consegue, pelas suas idéias, vencer os obstáculos e as dificuldades que surgem quando todos ficam reduzidos a poucos centímetros. Os detalhes narrados por Lobato do mundo microscópico de um jardim, assim como as situações de tensão, tais como as mortes de alguns adultos, também são comentados pelos leitores. A leitora Amarílis diz não ter gostado da parte que relata a viagem de Emília e Visconde pela Alemanha e a Rússia, provavelmente pelas descrições realistas e soturnas sobre o que a guerra havia causado nestes países.

Também sobre essa mesma obra um dos leitores escreve para tirar uma dúvida, sobre o personagem Burro Falante:

"No livro A Chave do Tamanho o sr. diz que o burro Falante nasceu na fazenda do Coronel Teodorico mas em outro livro o sr. diz que o Burro veio do pais das Fabulas.

Como me explica o fenômeno?”253

Por este pedido vemos que as crianças estavam atentas para detalhes sobre os personagens não somente dentro de uma mesma obra, mas também em toda a coleção. E exigem do autor uma coerência não só dentro do livro que estão lendo, mas também no que se refere a todo o conjunto das obras.

Diferentemente do que poderíamos imaginar as crianças não só comentavam as obras infantis lidas, mas também contos e obras dirigidos aos leitores adultos. Pela leitura das cartas verificamos que muitas crianças que já frequentavam o Ginásio liam os contos da produção adulta, muitos diziam ter se iniciado na leitura com as obras infantis e depois de certa idade passaram para a leitura dos contos, como vemos nas citações a seguir, a primeira de Sandra, leitora carioca de 18 anos:

\footnotetext{
${ }^{252}$ Carta de Amarílis Rocha de Cunto. Porto Alegre, 23/04/1943. IEB/ARAS. Cx 2 P 1 doc 16.

${ }^{253}$ Carta de Márcio Moreira Nascimento. São Paulo, 10/06/1943? IEB/ARAS. Cx 1 P 2 doc 47.
} 
"Fui, e ainda sou, leitora assídua de seus livros infantis. Passei-me depois para os contos, e agora ando ns traduções. Por sinal, aquela do ‘Piloto de Guerra’ de Saint-Ex está ótima. Gostei bastante.”254

Pela carta de Geraldo percebemos que os contos de Lobato começavam a ser lidos no Ginásio, e que os leitores continuavam admirando o escritor:

“Sou aluno do ginásio 'S. Paulo' e porta voz de meus colegas, todos admiradores do senhor desde pequeninos, desde os tempos em que líamos o ‘Narizinho Arrebitado’ até agora que já lemos ‘Urupês’.”255

Comentário semelhante, que nos revela a difusão dos contos de Lobato em livros didáticos e antologias, encontramos na carta de José Aurimar:

"Achei um livro muito interessante; outro dia, a minha professora falava numa de suas diversas páginas do livro Língua Portuguesa de Aníbal Bruno; todos os meus colegas se viam interessados na leitura de 'A morte e o lenhador' que prova mais uma vez o seu modo de arranjar um meio de ensinar a juventude.”256

E também na de Severino:

“Eu também leio 'Urupês', e acho que um dos melhores contos é 'Negrinha'. Esse conto nos obriga a pensar: Como a humanidade é cruel.”257

A primeira informação que nos chama a atenção é a de que os contos de Lobato eram veiculados em livros de Língua Portuguesa, sua leitura é feita no ambiente escolar. Mesmo assim os leitores que escrevem a Lobato elogiam esses contos, que os fazem pensar e refletir sobre diversos aspectos como o mencionado por Severino. Outros leitores parecem buscar os livros para adultos de Lobato nas prateleiras da biblioteca dos pais. E existem ainda os que, apesar de já terem entrado em contato com a leitura das obras para adultos, ainda preferem os livros infantis, como a jovem Edith:

\footnotetext{
${ }^{254}$ Carta de Sandra Martins Cavalcanti. Rio de Janeiro, 25/06/1944. IEB/ARAS. Cx 4 P 2 doc 22. ${ }^{255}$ Carta de Geraldo Galvão Leopoldo Santanna. São Paulo, 19/05/1945. IEB/ARAS. Cx 2 P 2 doc 23.

${ }^{256}$ Carta de José Aurimar da Cunha Barbosa. Rio de Janeiro, 12/08/1944. IEB/ ARAS. Cx 2 P 1 doc 33.

${ }^{257}$ Carta de Severino de Moura Carneiro Junior. Rio de Janeiro, 29/12/1945. IEB/ARAS. Cx 1 P 3 doc 25.
} 
“Já li diversos de seus livros para adultos: 'Negrinha', 'Na antevespera', 'O macaco que se fez homem', e outros; mas gosto inda mais das aventuras da Emilia, Narizinho, Pedrinho, que fazem a gente ver um mundo tão despreocupadamente feliz." ${ }^{258}$

Assim, apesar de mencionarem as leituras feitas no ambiente escolar, percebemos no trabalho com a documentação que as crianças e jovens se referiam na maior parte das vezes à leitura das obras de Lobato no âmbito doméstico, fora do ambiente escolar. Para todas essas crianças e jovens a leitura era prazerosa, as horas que passavam em aventuras com “o pessoal do Sítio” eram puro deleite. Mas o que fazia com que crianças que às vezes tinham tão pouca idade se transformassem em leitores ávidos?

As cartas não respondem de forma direta essa pergunta, é necessário buscar alguns indícios para que possamos compreender essa prática e o que a motivava. Em um primeiro momento percebemos que as crianças entram no mundo da leitura pelas mãos dos pais, como já vimos o prazer de ler é também um prazer compartilhado com os pais, vivenciado antes mesmo de serem alfabetizadas. O fato dos pais serem eles mesmos leitores e admiradores de Lobato faz com que as crianças tenham uma visão positiva do escritor. Em algumas cartas ela essa admiração é explícita:

“Aqui de casa não sou só eu fan dos livros do senhor, somos todos desde papae até os caçulas os três gêmeos de Campo Grande.”259

"Há muitos anos que papai havia comprado 'Emilia no paiz da gramática’, que eu e meus quatro irmãos adoramos.

Agora minha alegria aumentou por ter em meu quarto o retrato do querido autor de 'Urupês' de que papai me fala sempre.”260

“Todos daqui, papai, mamãe, minhas duas irmãs Silvia, Vilma e eu, desejamos sempre a sua felicidade, das pessoas de sua casa e do sítio

\footnotetext{
${ }^{258}$ Carta de Edith Canto. São Paulo, 24/04/1943. IEB/ARAS. Cx 1 P2 doc 18.

${ }^{259}$ Carta de Artur. Campo Grande, 20/10/1943. IEB/ARAS. Cx 2 P 1 doc. 26.

${ }^{260}$ Carta de Lindenbergh R. Faria. São Paulo, 04/08/1943. Cx 2 P 1 doc. 25.
} 
de Dona Benta. E não é só um voto de Natal e Ano Bom; é um desejo permanente."261

No entanto, a vivência familiar da leitura parece não ser a única responsável pela criação de um leitor. As crianças comentam em suas cartas, como já foi dito, que a facilidade da leitura das obras as estimulam a ler outros livros do autor, e uma vez que já circulam com desenvoltura pelo ambiente da leitura elas se sentem atraídas por outros autores e outras obras. O fato das obras de Lobato terem um humor bastante peculiar e histórias muito dinâmicas também faz com que os leitores voltem às obras muitas vezes, pois a leitura os diverte e emociona, como nos diz o leitor João Alphonsus, neto de Alphonsus Guimaraens:

"Eu sou assim: quando leio um livro fico com dó, fico contente,

fico com medo, como se fosse de verdade."262

Assim, se a leitura se iniciava como uma prática compartilhada pela família, logo em seguida passava a ser também algo individual, e que levava a estados de espírito diferentes. As crianças que se corresponderam com Lobato relatavam frequentemente as horas deliciosas que passavam em companhia de seus personagens. O que mais aparece na correspondência é o prazer que a leitura das obras proporciona. Mas também os leitores nos falam das idéias de Lobato veiculadas nos livros, desde opiniões sobre o petróleo, sobre a nação até mesmo sobre religião e ateísmo. Assim as próprias crianças mostram que ao lerem as obras entram em contato com um conteúdo que pode ser usado para a transformação da realidade.

Dessa forma as perguntas feitas no final do capítulo anterior não têm uma única resposta. As cartas mostram que a leitura era em parte evasão da realidade cotidiana, as crianças ao lerem os livros de Lobato, passavam horas vivendo em um mundo mágico e imaginário. Nesse sentido podemos afirmar que o autor conseguiu concretizar o desejo expresso ao amigo Rangel, em 1926: “Ainda acabo fazendo livros onde as nossas crianças possam morar”,263.

\footnotetext{
${ }^{261}$ Carta de Humberto Pires. São Paulo, 04/01/1945. IEB/ARAS. Cx 1 P 3 doc. 19.

${ }^{262}$ Carta de João Alphonsus de Guimaraens Filho. Belo Horizonte, 08/09/1943. IEB/ARAS. Cx 1 P 2 doc. 50 .

${ }^{263}$ MONTEIRO LOBATO.Barca de Gleyre: quarenta anos de correspondência literária entre Monteiro Lobato e Godofredo Rangel. 8.ed. São Paulo: Ed. Brasiliense, 1957. tomo II, p. 293.
} 
As cartas enviadas a Lobato também revelam, em certa medida, o alcance que as idéias veiculadas nas obras infantis atingiram. Muitos leitores principalmente jovens acolhiam as idéias do autor e por meio da correspondência compartilhavam seus ideais de transformação da sociedade, solidarizando-se na luta do petróleo, ou por ocasião de sua prisão, assim como também nas críticas ao governo autoritário de Vargas.

No entanto, principalmente para os mais novos, a leitura criava uma realidade que era imaginariamente e intensamente vivida. Não só as crianças passavam a morar nos livros, vivendo cada aventura como se fossem eles próprios os protagonistas, mas também faziam com que os personagens e suas invenções ganhassem vida própria, fazendo bonecas de pano que se parecessem com Emília, realizando experiências “científicas” como as do Visconde, enviando cartas para os personagens e convidando-os para festas de aniversário.

Andersen já havia mencionado em um de seus contos a possibilidade dessa mágica: no início de “Cisnes Selvagens” aparece uma pequena princesa que possuía um livro que valia a "metade de um reino”, pois nele tudo estava vivo, “Os pássaros cantavam e as pessoas saíam do livro e falavam” e quando a menina virava a página “todos pulavam imediatamente de volta para o livro"264.

Esse mundo imaginário que se torna real parece ter sido também a maneira pela qual as crianças se relacionavam com os livros e os personagens criados por Lobato. Dessa maneira podemos compreender melhor uma carta como a de Maria Eugênia, enviada a Dona Benta, pelos cuidados de Monteiro Lobato:

"D. Benta,

Eu gosto muito da senhora.

Eu queria uma caixinha de pó de pirlimpimpim si a senhora quizer me fazer esse grande favor.

Eu estou lendo a sua geografia.

Maria Eugenia.,265

\footnotetext{
${ }^{264}$ Walter Benjamin no ensaio "Visão do livro infantil" comenta essa passagem sem especificar a que conto se refere. BENJAMIN, Walter. Reflexões sobre a criança, o brinquedo e a educação. São Paulo: Duas Cidades; Ed. 34: 2002.

${ }^{265}$ Carta de Maria Eugênia. Forte de Coimbra, Mato Grosso, 19/07/1945. IEB/ARAS. Cx 2 P 2 doc 1.
} 
Também a litografia de Jean G. Villin feita para a edição de Reinações de Narizinho, de 1931, é nesse sentido emblemática de como as crianças ao lerem as obras davam vida aos personagens, que saíam das páginas impressas e passavam então a habitar o seu mundo cotidiano.

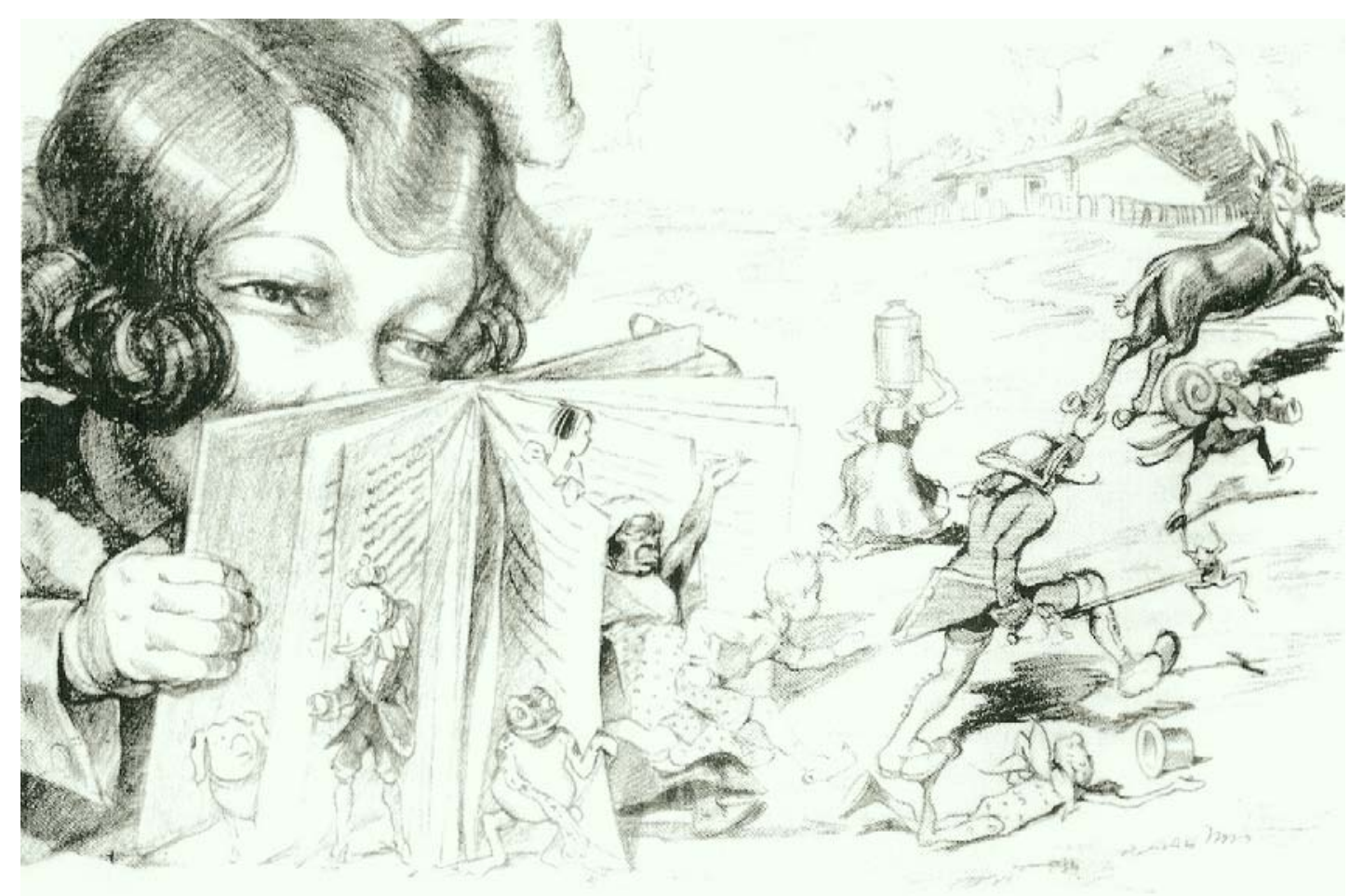

Ilustração de J. G. Villin para Reinações de Narizinho 


\section{O Jornal “A Voz da Infância”}

"De repente as palavras vestem seus disfarces e num piscar de olhos estão envolvidas em batalhas, cenas de amor e pancadarias. Assim as crianças escrevem, mas assim elas também lêem seus textos.”

Walter Benjamin

As cartas enviadas por leitores a Lobato nos mostraram como sua obra foi recebida e quais eram seus aspectos mais apreciados, no entanto, essas cartas abordam apenas pontualmente obras de outros escritores, sejam eles nacionais ou estrangeiros. Na tentativa de compreender melhor a recepção da leitura literária na infância procuramos trabalhar com uma outra fonte documental que veiculasse a opinião que as crianças tinham sobre o que liam. Desta forma foi importante a leitura e análise de um jornal publicado pelas crianças frequentadoras da Biblioteca Infantil Municipal, intitulado A Voz da Infância.

A Biblioteca Infantil foi criada no contexto de organização do Departamento de Cultura de São Paulo, em abril de 1936. Sua primeira diretora foi a educadora Lenyra Fraccaroli, que havia montado uma primeira biblioteca infantil no Instituto de Educação ligado à Escola Caetano de Campos. Na Biblioteca Infantil Municipal seu papel foi o de organizar todo o projeto e instalação da instituição, tendo também criado a partir de 1946 uma rede municipal de bibliotecas voltadas à infância, por vários bairros paulistanos. O trabalho de Gabriela Pellegrino Soares analisa com profundidade a mediação que Lenyra Fraccaroli teve e sua importância na seleção, difusão e promoção da leitura literária em nosso país. ${ }^{266}$

A Biblioteca Infantil foi primeiramente instalada em uma casa na rua Major Sertório, n. 690, no bairro de Vila Buarque. A casa adaptada tinha salas para a leitura de livros e revistas, assim como uma sala para festas e jogos e uma que foi criada especialmente para a projeção de filmes. Durante o primeiro ano o número de visitas feitas a ela por crianças foi de 25.547, contando inclusive as

\footnotetext{
${ }^{266}$ SOARES, Gabriela Pellegrino. Semear Horizontes. Belo Horizonte: Ed. UFMG, 2007. p. 309-343.
} 
visitas feitas para as sessões de cinema. A biblioteca permaneceu até 1945 neste endereço quando mudou para o palacete de Rodolfo Miranda, na rua General Jardim, e em 1950 se transferiu definitivamente para o prédio que ocupa até os dias de hoje, na mesma rua, tendo uma praça que a envolve.

A diretora, Lenyra Fraccaroli deveria ser uma presença constante e querida nas salas de leitura e em outras atividades pois, pela documentação, percebemos inúmeros cartões de natal e aniversário dirigidos a ela pelas crianças. Temos também cartas de frequentadores e ex-consulentes, que agradecem-na pela orientação nas leituras e as agradáveis horas passadas na biblioteca entretidos em leituras e jogos. Uma das cartas interessantes guardadas no acervo é de Paulo Vanzolini, na época com doze anos de idade, mostra sua amizade para com a diretora, além de seu interesse já na época pela zoologia:

“Querida dona Lenyra.

Abraços. Chegamos bem ao Guarujá, apesar de sairmos daí no dia 5 e chegarmos aos 45 minutos do dia 6 . A saudade já chegou, mas ainda não tinha apertado muito, quando ontem á noite comecei a pensar, e senti um apertinho na garganta. Então compreendi que a consciência estava me mordendo por não ter escrito ainda, e apazigüei-a, pensando: ‘Amanhã mesmo escreverei’. De fato, hoje fiz várias tentativas para escrever uma carta 'almofadinha' com letra de menina, papel sem pauta, e outras atrapalhações mais, mas não obtive um resultado satisfatório. Então, resolvi escrever com minha letra, num papel pautado, como escreve quem tem pouco capricho e quer mostrar franqueza.

Os fatos interessantes são tantos, que não sei por onde começar. Dizendo do Museu? Sim. É uma boa idea. Trouxe o Oscarsinho, que está dando sorte. Já arranjei um ouriço do mar, um guaiá, um guaiazinho, um amborê, um guará bebê, duas tiniúnas, e outros exemplares que não interessam a senhora, que não é apaixonada pela História Natural. Digo apenas que guaiá é uma espécie de caranguejo e o resto é peixe.”267

\footnotetext{
${ }^{267}$ Carta escrita por Paulo Emílio Vanzolini. Guarujá, 11/12/36. Biblioteca Municipal Monteiro Lobato. Acervo de Bibliografia e Documentação. Álbum de Correspondência Recebida. 1933-1943.
} 
Esta carta foi enviada em dezembro de 1936, havia menos de um ano que a Biblioteca funcionava, mesmo com tão pouco tempo percebemos que a relação que o consulente tem para com a diretora era de intimidade e amizade. Provavelmente porque Lenyra Fraccaroli não era uma diretora distante.Vemos pela documentação escrita e fotográfica que ela organizava e levava as crianças em excursões, em uma das quais aparece o menino Paulo Emílio. Além disso, organizava festas e horas do conto convidando escritores conhecidos das crianças. Fazia então com que a biblioteca fosse mais do que uma simples instituição municipal de leitura voltada ao público infantil. A ligação do menino Paulo Emílio com a diretora deveria ser também próxima devido às atividades que este tinha na biblioteca. Paulo Emílio foi uma das crianças que participaram da criação do jornal A Voz da Infância, no quarto número, de setembro de 1936, ele aparece como diretor, permanecendo no cargo até novembro de 1937.

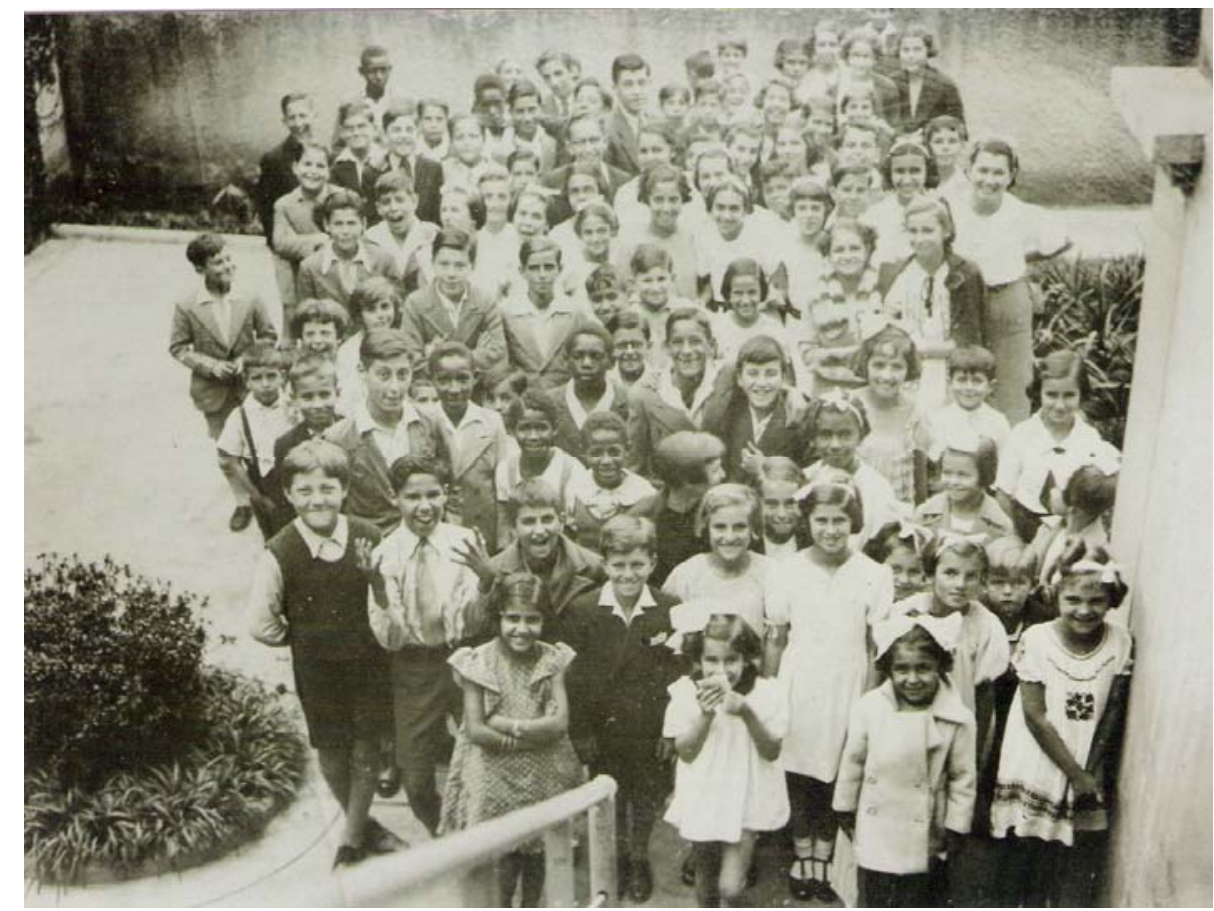

Crianças esperam pela sessão de cinema na Biblioteca Infantil Acervo Seção de Bibliografia e Documentação - BML/PMSP

As atividades que as crianças poderiam fazer na Biblioteca Infantil iam além da leitura e empréstimo de livros e revistas, havia uma sala destinada aos jogos de tabuleiro, como o xadrez e damas, além de uma coleção de gravuras que 
poderiam ser copiadas. Havia também a Hora do Conto, muitas vezes com a participação de escritores conhecidos como Monteiro Lobato, Tales de Andrade e Malba Tahan, para citar apenas alguns. Assim como também o cinema infantil que exibia fitas comerciais, principalmente, de Walt Disney e Shirley Temple. A escolha de filmes comercialmente atrativos tinha uma razão: estimular a freqüência de leitura, pois apenas os consulentes que tivessem retirado dois ou três livros durante a semana poderiam ganhar ingressos para os filmes, que eram, aliás, concorridíssimos como vemos pelas fotos.

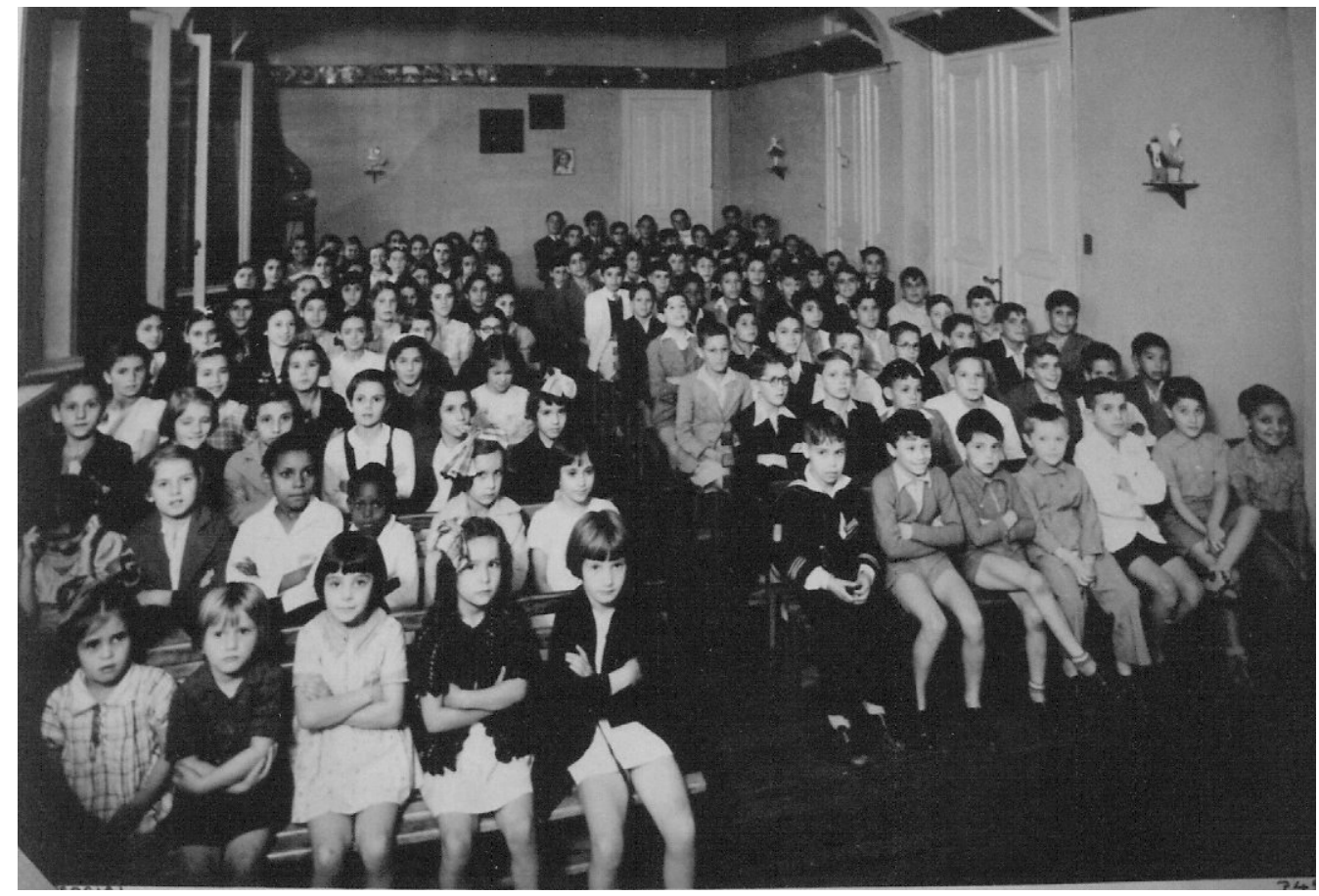

A Sala de Projeção da Biblioteca Infantil repleta de crianças, ao fundo a foto de Shirley Temple. Acervo Seção de Bibliografia e Documentação - BML/PMSP

Mas quem eram as crianças que freqüentavam a biblioteca? No Acervo de Bibliografia e Documentação, ainda estão preservadas as fichas de inscrição dos consulentes. As feitas nos primeiros anos de funcionamento da biblioteca constam apenas o nome, idade e endereço da criança, mas naquelas feitas a partir do final da década de 30 temos as informações sobre os pais, se eram estrangeiros e que profissão exerciam, assim como se possuíam irmãos e suas idades. Essas fichas que ainda necessitam um trabalho aprofundado podem nos revelar, em certa medida, qual o perfil dos frequentadores. Em nossa pesquisa nos utilizamos delas principalmente para compreender quem eram as crianças que colaboravam no 
jornal A Voz da Infância. De forma geral as fichas mostram que em grande parte os consulentes residiam nas imediações da biblioteca, principalmente no bairro de Vila Buarque, mas em alguns casos eles também vinham de regiões mais afastadas como a Lapa e Vila Mariana. O fato de ser a única biblioteca destinada às crianças na cidade de São Paulo, até a instalação da Biblioteca Infantil do Itaim, em 1947, deveria fazer com que mesmo leitores que morassem em bairros afastados a visitassem. As profissões dos pais mostram que em grande parte as crianças eram filhas de uma camada de profissionais liberais ou funcionários públicos, no entanto, temos também filhos de vendedores ambulantes, motoristas e operários, em geral temos uma diversidade muito grande no que diz respeito as profissões dos pais de freqüentadores da Biblioteca.

Sobre a origem sócio-econômica das crianças freqüentadoras da Biblioteca temos, em fevereiro de 1940, um artigo publicado na Revista do Arquivo Municipal, que analisa as profissões dos pais e os bairros de onde as crianças eram provenientes. A pesquisa havia sido feita pela Subdivisão de Documentação Social e Estatísticas do Departamento de Cultura, juntamente com o Laboratório de Psicologia do Instituto de Educação e pretendia verificar se os frequentadores da Biblioteca eram de origem operária ou não. Tendo sido realizada em 1938 a pesquisa se baseou nos dados de 500 crianças e foi publicada com o título “Condições econômicas dos pais das crianças que freqüentam a Biblioteca Infantil”. ${ }^{268}$ A pesquisa separava as profissões em três categorias: A (consideradas operárias, como: açougueiro, alfaiate, jardineiro, mecânico, motorista, pedreiro, sapateiro entre outros), B (considerada não-operária, como: caixa de banco, chefe de trem, comerciante, escriturário, guarda-livros, inspetor da polícia, repórter, tipógrafo, entre outros) e C (também não operária, mas com remuneração maior, como: advogado, boticário, contador, cirurgião, dentista, professor, proprietário entre outros). Ao se cruzar a informação das profissões dos pais com a dos bairros onde residiam, chegou-se a informação de que 34\% das crianças tinham origem operária e 66\% de origem não operária. Como vemos o fato de a Biblioteca localizar-se no bairro de Vila Buarque foi muito importante na determinação de quem era majoritariamente seu público, pois o bairro assim como os adjacentes,

${ }^{268}$ Revista do Arquivo Municipal. n. 64, fevereiro de 1940. 
Centro, Consolação e Campos Elíseos eram ocupados por uma classe social mais abastada.

A pesquisa não menciona que as crianças provenientes das classes sociais mais humildes além de não terem uma escolarização regular, não podendo assim constituir um público leitor, quando eram alfabetizadas e tinham interesse em freqüentar a Biblioteca, não a poderiam fazer, pois em grande parte começavam a trabalhar cedo. Como o horário de funcionamento da Biblioteca era restrito, poucas eram as crianças que trabalhando conseguiam ainda freqüentar a biblioteca. Mesmo assim aparecem, mesmo que tragicamente, no jornal registros de leitores que trabalham, como no caso do leitor José Corrêa de Toledo:

"Lamentável. Na tarde de 21 de novembro, quando voltava do serviço, foi vítima de um desastre fatal, o menino José Correa de Toledo, freqüentador assíduo da Biblioteca.

Um automóvel que vinha em desabalada corrida, o acolheu sob suas rodas na rua da Consolação, fraturando-lhe o craneo e ocasionando sua morte, momentos depois na Santa Casa.

Esse menino trabalhador, estudioso e bom sentia-se feliz, quando podia roubar alguns momentos de seu trabalho para se deliciar com os nossos livros e ... com o nosso cinema.,269

Em janeiro de 1943, temos uma estatística publicada na Voz da Infância que nos revela mais algumas características do público que frequentava a Biblioteca Infantil. Durante o ano de 1942 haviam sido matriculadas 1.217 crianças, sendo 880 meninos e 337 meninas. Desse total 423 freqüentavam os Grupos Escolares, 405 já estavam nos Ginásios, 36 no Comércio, o documento não especifica se escola técnica, 243 crianças estavam em outras escolas e 110 crianças não freqüentavam nenhuma escola, já haviam terminado o curso primário e não estudavam mais. A grande maioria dos frequentadores era brasileira, sendo apenas 55 o número de crianças estrangeiras. A faixa etária mais presente é dos 9 aos 14 anos. Os bairros com maior número de consulentes eram Vila Buarque, Bela Vista, Campos Eliseos, Santa Cecília, Bom Retiro e Consolação. ${ }^{270}$ Essa pesquisa não menciona, mas pelas das fichas de inscrição na Biblioteca verifica-se que parte considerável das crianças estudavam nas escolas da região, muitas delas

\footnotetext{
${ }^{269}$ Voz da Infância. n. 6, novembro de 1936. p. 8.

${ }^{270}$ Voz da Infância. n. 79, janeiro de 1943. p. 7.
} 
em escolas particulares como o Colégio Rio Branco, o Colégio Visconde de Porto Seguro e o Mackenzie.

Temos assim, a partir dos dados das duas pesquisas e das fichas de inscrição na Biblioteca uma idéia de quem eram as crianças frequentadoras, é interessante notar que na estatística publicada pela Voz da Infância, o número de meninas é duas vezes menor do que o de meninos. As razões para essa diferença não puderam ser explicadas pela documentação, no entanto, essa porcentagem parece refletir a condição da mulher durante o período, principalmente nas camadas médias da população as meninas eram educadas para trabalharem no lar e tinham relativamente pouca autonomia fora do ambiente doméstico. Podemos imaginar assim, que as meninas nas décadas de 30 e 40 não costumavam circular sozinhas pela cidade, limitando a possibilidade de frequentarem a Biblioteca. O fato dos pais dos frequentadores não poderem entrar na biblioteca, durante o período estudado, talvez fosse um dos motivos para que várias meninas não a frequentassem. Não podemos esquecer ainda que nesse período as classes escolares de Grupos e Ginásios eram separadas por sexo, e talvez alguns pais não vissem com bons olhos meninos e meninas convivendo em um único espaço, por vezes compartilhando uma mesma mesa. Desta forma, a presença de meninas na redação da Voz da Infância foi menor que a dos meninos, do total de 368 participantes do jornal de 1936 a 1950, 114 eram meninas, enquanto que 254 eram meninos. ${ }^{271}$ A relação existente entre o número de frequentadoras era equivalente ao número das meninas que colaboravam no jornal. Outro dado importante que as fichas de inscrição dos frequentadores nos revelam é que muitos irmãos frequentavam juntos a Biblioteca, assim como também participavam juntos da confecção do jornal, como no caso dos irmãos Henrique e Mário Capuani, Lélia e Ligia Silva Kuntz Busch e Victor e Moisés Nussenzveig, para citar alguns nomes que colaboraram consideravelmente no $A$ Voz da Infância. $^{272}$

O jornal A Voz da Infância era composto de cerca de dez páginas mimeografadas, em azul ou preto. A partir do número 102, de dezembro de 1944, temos a publicação sendo realizada em quatro cores, mas, provavelmente, pela

\footnotetext{
${ }^{271}$ Andreotti, Azilde. O Jornal como fonte de pesquisa.Um projeto de educação através do A Voz da Infância (1936-1950). Tese de Doutorado. Faculdade de Educação. UNICAMP/SP. 2004. p.32.

${ }^{272}$ Essas informações forma coletadas nas fichas de inscrição dos freqüentadores da Biblioteca. Preservadas na seção de Bibliografia e Documentação.
} 
dificuldade que o processo acarretava, essa impressão apesar de atraente foi abandonada alguns números depois. O jornal era totalmente feito pelas crianças da escolha das matérias à impressão em mimeógrafo. Em um primeiro momento a diretoria do Jornal, que era escolhida anualmente pelos frequentadores da Biblioteca, reunia-se para estabelecer quais artigos, contos, piadas e desenhos fariam parte do número a ser publicado. Estas reuniões estão documentadas, pois as crianças faziam uma ata para cada uma delas. ${ }^{273}$ Depois de resolvido o conteúdo a entrar na revista as crianças datilografavam todo o seu conteúdo, seguindo um determinado padrão, e montavam todo o jornal com os desenhos e charadas, para em seguida utilizarem-se do mimeógrafo, comprado para esta finalidade pela biblioteca, para fazerem as cópias. Estas cópias eram vendidas para os consulentes da Biblioteca e o dinheiro era revertido para compra de material para a publicação de novos números. No início de nossa pesquisa imaginávamos que o jornal tinha uma supervisão atenta da bibliotecária chefe, Lenyra Fraccaroli, ou das bibliotecárias Haydée e Noêmia, que auxiliavam das salas de consulta e empréstimo. Contudo no decorrer da pesquisa, assim como aconteceu com as cartas fomos percebendo que a escrita era mesmo das crianças, talvez os adultos da instituição sugerissem algum tema, como o do primeiro número, que tratava de Carlos Gomes, mas a pesquisa, a escrita e a ilustração das matérias eram feitas pelos freqüentadores. Isto ficou mais evidente quando analisamos as cartas que as crianças escreviam entre elas, e que foram publicadas pelo jornal, assim como as atas e outros documentos relativos ao jornal.

De junho de 1936 a dezembro de 1948, o jornal saiu regularmente todos os meses, em alguns períodos chegou a ter quatorze páginas, mas na maioria das vezes saía com dez páginas, todas elas com ilustrações. Durante a pesquisa com $A$ Voz da Infância percebeu-se que o jornal seguia em parte o modelo das revistas voltadas à infância, mais notadamente da revista $O$ Tico-Tico. Muitas seções eram inspiradas em seções da revista, como na intitulada "Folha Charadística” ou mesmo nas histórias sobre heróis e personalidades da história brasileira. Até mesmo nos desenhos e histórias ilustradas com quadrinhos vemos o uso de alguns desenhos como Gato Félix, Mickey Mouse ou ainda nos personagens inspirados

\footnotetext{
${ }^{273}$ As atas e outros documentos produzidos pelas crianças estão preservados na seção de Bibliografia e Documentação da Biblioteca Monteiro Lobato. Na Caixa 1, intitulada "Atas e Documentos da Voz da Infância”.
} 
em Reco-reco, Bolão e Azeitona. No entanto, não eram aceitos desenhos, charadas ou mesmo contos plagiados de outras revistas, nas atas ficava explícito o cuidado que as crianças tinham para que o material fosse inédito.

Tomemos um número como exemplo do que era publicado no jornal. $\mathrm{O}$ segundo número do jornal se inicia com uma entrevista feita por dois membros da diretoria do jornal: Benedito Mendes e Gastão Gorenstein a Monteiro Lobato. Logo no início quando Benedito Mendes começa a entrevistá-lo, o autor pede para que o entrevistador "não fale complicado assim senão eu não entendo”. A entrevista comenta vários pontos: aborda os personagens, o livro Emília no Pais da Gramática, e trata da polêmica opinião de Lobato com relação à acentuação das palavras. A entrevista se encerra com os meninos pedindo uma sugestão do autor porque os frequentadores da Biblioteca gostariam de lhe fazer uma homenagem. E Lobato responde:

“- Nada mais fácil. Mandem-me de presente uma dúzia de laranjas tangerinas, daquelas graúdas, de casca bem solta. Que fruta boa a laranja, hein?

Apesar de toda a solenidade de Mendes e Gorenstein os olhinhos deles brilharam - e veio-lhes água na boca. Por mais que a gente se finja de gente grande, só a lembrança de uma laranja cravo já crianciza a gente...,274

Nessa frase final fica evidente que as duas crianças tinham consciência que estavam tentando parecer durante a entrevista mais velhas e maduras, que naturalmente eram. Quando Lobato menciona as laranjas, com as quais deveria ser feita a homenagem, eles se comportam como as crianças que realmente são.

Logo em seguida à entrevista temos a ilustração de uma menina lendo em uma mesa, com a estante de livros da Biblioteca atrás. Muitos desenhos veiculados no jornal retratavam crianças lendo, ou mesmo como o desenho da página seguinte, que mostra um homem desanimado e triste com um papel na mão, onde está escrito "Despedido por não saber ler”. O homem se lembra dele ainda menino no colo da mãe que pedia para que ele estudasse. Em vários dos desenhos encontrados em $A$ Voz da Infância temos essa ênfase à leitura, e nas

${ }^{274}$ Entrevista sensacional. A Voz da Infância. n.2, julho de 1936. p. 3. 
conseqüências indesejáveis que a falta de estudo acarreta. Outros desenhos retratam personagens de obras infantis, assim como seus criadores. Somente a partir do quarto número é que temos a criação de histórias ilustradas, que aos poucos vão se transformando em quadrinhos propriamente ditos. Já durante a década de 40, temos colaboradores que eram excelentes desenhistas e que criam personagens e histórias que foram publicadas em números seguidos, como Hamilton de Souza.

A importância do estudo e da leitura é bastante freqüente no discurso dos colaboradores, assim como também se valoriza a criança que trabalha, mas não deixa com isso de se instruir. O relato, já mencionado, sobre o acidente fatal ocorrido com uma das crianças que frequentava a Biblioteca é revelador.

Em muitos números do jornal fica evidente a importância dada ao estudo e ao trabalho. Às vezes uma redação valoriza aquele que não tendo recursos materiais se esforça para estudar, ou por vezes criticam as crianças que sendo ricas não se esforçam nos estudos. Toda essa mentalidade de valorização do estudo e da ascensão social com base na escolaridade foi abordada na tese de doutorado intitulada O Jornal como fonte de pesquisa, de Azilde Andreotti ${ }^{275}$. A autora analisa também outros pontos recorrentes na escrita do jornal $A$ Voz da Infância, como a visão na qual por meio da escola a pátria seria engrandecida e a nação fortalecida.

Em todo o percurso do jornal vemos que comentários e apreciações literárias estavam sempre presentes. Ainda no segundo número temos o artigo "Livros", escrito por Lygia Caropreso, nele a colaboradora comenta suas preferências literárias:

"Eu fui e ainda sou uma grande leitora. Leio muito e sempre com crescente prazer. (...) Quando era menor, dedicava as leituras de livros fantásticos, contos de fadas, etc.

Depois com meu crescimento em instrução comecei a desdenhar esses livros para gostar dos livros mais reais. Destes os que mais gostei, e ainda gosto são: 'Desastres de Sofia' e todos os livros da Condessa de Segur. 4 raparigas, Colégio da Ameixoeira, Alguns anos depois e Rapazes

\footnotetext{
${ }^{275}$ ANDREOTTI, Azilde. O Jornal como fonte de pesquisa.Um projeto de educação através do A Voz da Infância (1936-1950). Tese de Doutorado. Faculdade de Educação. UNICAMP/SP. 2004.
} 
de Maria João, todos eles de Maria Paula Azevedo. Destas obras gostei tanto, que li três ou quatro vezes cada exemplar(...)

Eu tenho pena dos que não gostam de ler. Esses que infelizmente são em grande número, nunca poderão sair dos limites de um pensamento material, sem conhecerem os tesouros que encerra a imaginação. Mas não é só a leitura de contos, de revistas, de histórias que devem entreter nosso pensamento. A narrativa de viagens bem escritas, poderão auxiliar-nos muito no estudo da Geografia. (...)

E é por isso caros leitores que eu digo: Leiam, que não se arrependerão.

Mas leiam livros escolhidos, como são os que existem na 'Biblioteca Infantil'.,276

O artigo escrito pela menina Lygia, de catorze anos, é bastante interessante pois toca em pontos que também aparecem nas cartas enviadas a Lobato. A leitora diz ter iniciado seu percurso de leitura com os contos de fadas e outras obras "fantásticas”, que aqui parece designar livros onde um universo onírico e de fantasia estão presentes passando, na medida em que crescia, para obras “mais reais”, ou seja livros onde os personagens se vêem em cenas do cotidiano, que poderiam acontecer de fato. Destes últimos os preferidos pela menina são os livros da Condessa de Ségur e de uma autora portuguesa Maria Paula Azevedo ${ }^{277}$, sendo que esses últimos foram relidos três ou quatro vezes. Aqui, como também aparece nas cartas, os leitores relêem as obras inúmeras vezes, não por não terem acesso a outras obras, mas por apreciarem muito determinados livros. A menina também salienta que os livros de viagens "bem escritos” devem ser lidos pois auxiliam na compreensão da geografia. Também nas cartas percebemos como as crianças valorizavam livros que as auxiliassem nos deveres escolares e na aquisição de um conhecimento considerado por elas importante. No entanto, a leitora também tem consciência de que está escrevendo para um público, não deixando de aconselhá-lo a leitura, mas a leitura de livros “escolhidos, como são os que existem na Biblioteca Infantil”. Neste ponto a

${ }^{276}$ CAROPRESO, Lygia. Livros. A Voz da Infância, n. 2, jul. 1936. p. 6.

${ }^{277}$ A autora portuguesa Maria Paula Azevedo publicou em 1922 um romance histórico intitulado Brianda, em 1923 publicou Theatro para crianças, no entanto, não foi possível determinar as datas de publicação dos livros aos quais a menina se refere. Uma das obras mencionadas Rapazes de Maria João é uma adaptação de um livro de Louisa May Alcott intitulado Life at Plumfields with Jo's boys. 
escrita do jornal diferencia-se da das cartas, pois as crianças são conscientes de estarem escrevendo para muitos, e de seu papel na divulgação de hábitos considerados por elas saudáveis.

Ainda neste segundo número do jornal $A$ Voz da Infância temos reproduzida uma ficha de leitura. A Biblioteca ao emprestar seus livros solicitava aos consulentes que preenchessem uma ficha onde várias perguntas eram feitas, por essas perguntas as bibliotecárias poderiam perceber se a leitura havia sido bem realizada ou não, podendo posteriormente indicar livros mais adequados àquela criança.

Nesse número a ficha escolhida para ser publicada foi a de Paulo Emílio Vanzolini, sobre o livro O Saci, de Monteiro Lobato. Essa ficha foi escolhida como a melhor ficha feita durante aquele mês e a razão para publicá-la era a de que através dela "todos os leitores possam julgar como se faz uma boa ficha”. A ficha faz um pequeno resumo da história do livro, de forma bem objetiva, e depois responde as perguntas:

“O que achou do livro? Ótimo

É realidade ou ficção? Fantasia

Qual o personagem que mais o impressionou? Pedrinho

Porque? Porque tem sangue frio.”

As fichas de leitura foram muito esporadicamente publicadas no jornal, e nesse número em específico parece ter sido publicada para auxiliar as outras crianças freqüentadoras, dando um bom modelo a ser seguido. As fichas de leitura preenchidas pelos leitores infelizmente não foram encontradas no acervo preservado pela Biblioteca.

Ainda no segundo número da revista temos uma notícia escrita por Eleonora Cardoso, de treze anos, sobre a Corrida Automobilística realizada em São Paulo. Notícias sobre o cotidiano da cidade eram também muito freqüentes no jornal, e por meio delas podemos ter uma idéia de como a criança percebia o meio urbano, e também qual era o seu cotidiano. Nesta matéria a menina Eleonora relata que acompanhou a corrida pelo rádio e nos conta como foi irradiada a notícia sobre o acidente com um dos carros que se desgovernou e atingiu a população que assistia a corrida, matando e ferindo muitas pessoas. Aliás, um dos assuntos que aparecem com assiduidade nas páginas do jornal infantil é o 
atropelamento de crianças, por carros ou mesmo bondes. Até mesmo na seção de piadas do jornal encontramos o assunto:

"Na classe:

A professora - Um sinônimo de ambulância.

Pedrinho - Um carro que salva um e mata três.”

Esse também foi um assunto abordado pela resenha, do livro $O$ Pequeno Pedestre, de Vicente Guimarães. A autora da resenha Wilma Leite Silva, de dez anos, indica a leitura deste livro como forma de se evitar os acidentes e atropelamentos:

“Nós as crianças ao atravessarmos a rua devemos sempre olhar de todos os lados. Quantos pais trazem os corações enlutados por terem perdido seus filhos por um simples descuido dos mesmos.

Ás vezes a culpa é do motorista, porém a maior parte das vezes é a falta de cuidado do pedestre.

Quantos acidentes poderiam ser evitados lendo: 'O Pequeno Pedestre’ de Vicente Guimarães.”278

A indicação do livro tem, assim, um motivo de ordem prática: evitar acidentes, no entanto, a menina não deixa de analisar o livro do ponto de vista material, comentando sobre as ilustrações e também sobre a linguagem utilizada pelo autor:

“É um livro dedicado inteiramente a garotada. As figuras são sugestivas e explica tudo por meios simplíssimos e com palavras tão fáceis que mesmo uma criança de 5 anos pode entender.”279

O segundo número do jornal, assim como todos os outros, também veiculou algumas curiosidades, propagandas como a do suplemento O Gury, da Folha da Noite, ou do colégio Paulista, uma carta enigmática, palavras cruzadas e informações sobre o movimento da biblioteca.

Essa seção que mostra o movimento em números, assim como também os autores e livros mais retirados pelos consulentes, existirá em todos os números do jornal e, por ela podemos perceber a preferência dos frequentadores da Biblioteca. No entanto, devemos estar atentos para o fato de que os autores mais retirados também pudessem ser aqueles que tinham mais obras disponíveis para a consulta

\footnotetext{
${ }^{278}$ SILVA, Wilma Leite. O pequeno Pedestre. A Voz da Infância, n. 60, jun. 1941, p. 8.

${ }^{279}$ Idem. P.8.
} 
na Biblioteca. Infelizmente, não foram preservadas as listagens de aquisição de obras pela Biblioteca Infantil durante o período estudado, não sendo possível precisar com exatidão quais obras compunham seu acervo e quantos exemplares havia de cada. No entanto, a partir da Bibliografia infantil de obras brasileiras, publicada em 1945 por Lenyra Fraccaroli, podemos ter uma idéia de quais obras constituíam o seu acervo pois, como a própria autora nos conta, a Bibliografia foi feita tomando como base o acervo da Biblioteca que estava sob sua direção. Gabriela Pellegrino Soares em seu trabalho A semear horizontes analisa detalhadamente a Bibliografia organizada por Lenyra, notando inclusive algumas omissões, como as de obras voltadas para o público juvenil. Assim, autores como Karl May, Emilio Salgari, Robert Louis Stevenson, Rudyard Kipling, entre outros, que produziram obras de ação e aventura para jovens não são mencionados por Lenyra, provavelmente porque ela estava preocupada em enumerar obras para crianças de até catorze anos. Gabriela P. Soares indica-nos como a Bibliografia revela quais autores tinham um número maior de publicações que outros. Assim temos Disney publicado, principalmente, pela Companhia Melhoramentos com o maior número de edições, setenta e cinco, sendo seguido por Monteiro Lobato, com cinqüenta e sete livros, entre as obras publicadas na Companhia Editora Nacional e a Brasiliense. A Condessa de Ségur mencionada pela menina Lygia ficava em quinto lugar com quarenta edições, feitas por várias casas editoras, em sua maioria portuguesas. Alguns outros autores que não são mencionados pelo jornal $A \mathrm{Voz}$ da Infância aparecem como terceiros e quartos lugares, sendo eles o escritor português Gabriel Ferrão e Renato Sêneca Fleury. Gabriela P. Soares também nos informa que apesar de não estar mencionado na Bibliografia, outro escritor com muitas obras editadas era Karl May que teve seus quarenta e cinco títulos publicados pela Editora Globo. ${ }^{280}$

O panorama traçado pela Bibliografia quando comparado com as informações retiradas da leitura do jornal A Voz da Infância revela um quadro bastante interessante. Em primeiro lugar temos uma pluralidade de publicações que vai desde os álbuns em pequeno formato e cheios de ilustrações de Disney, que remetem nitidamente a sua produção cinematográfica, até obras com pouquíssimas ou nenhuma ilustração, encadernadas em couro com letras

\footnotetext{
${ }^{280}$ SOARES, Gabriela Pellegrino. Semear Horizontes. Belo Horizonte: Ed. UFMG, 2007. p. 319-337.
} 
douradas, com centenas de páginas. Materialmente vemos que as crianças tinham acesso à obras muito variadas e que, já nas décadas de 30 e 40, as editoras brasileiras e estrangeiras se preocupavam com o aspecto visual dos livros a serem publicados para crianças. Vemos também que a maior parte dos autores de grande sucesso internacional foram aqui traduzidos e editados, estando à disposição dos leitores da Biblioteca Infantil. Assim, podemos pensar que os livros que aparecem como os preferidos pelos leitores da Biblioteca são de fato representativos, dado o universo de obras disponíveis para a consulta e empréstimo. No entanto quando pensamos nos autores com mais circulação na Biblioteca esse número deve ser relativizado, pois como Disney e Lobato, assim como Karl May tinham uma quantidade muito grande de obras disponíveis para empréstimo não seria de se estranhar que fossem os campeões em número de consultas e empréstimo. Mesmo assim seu sucesso não pode ser menosprezado, pois como vimos outros autores como Gabriel Ferrão e Renato Sêneca Fleury tinham também uma grande quantidade de obras disponíveis na Biblioteca, e somente a disponibilidade de exemplares não fez com que fossem lidos pela maioria dos consulentes.

Essa seção “Movimento da Biblioteca” durante o período estudado, de junho de 1936 a dezembro de 1948, dava indicação sobre o número de exemplares retirados para consulta, número de visitas à Biblioteca, autores preferidos e livros mais retirados. Monteiro Lobato, como era de se esperar, figurava praticamente em todos os meses como um dos autores preferidos, assim como muitos dos seus livros apareciam como sendo um dos mais retirados. Monteiro Lobato só tinha um autor que lhe fazia concorrência em termos de autor preferido, Karl May, principalmente com seu livro Winnetou.

O próprio Monteiro Lobato em uma carta dirigida aos diretores de $A \mathrm{Voz}$ da Infância diz que, ao ler o jornal produzido pelas crianças, sempre verificava se estava em primeiro ou segundo lugar na preferência dos leitores:

"Leio as patriotadas todas e vou ver no 'Movimento da Biblioteca' se ainda estou bem cotado - fico triste quando o Karl May me derrota. Mando a 'Voz' para o Sítio do Picapau Amarelo, porque é o único jornal que D. Benta deixa lá entrar.”281

${ }^{281}$ Carta de Lobato a 'Voz'. A Voz da Infância, n. 88, out. 1943. p. 5. 
Lobato deveria mesmo ser um dos autores preferidos pois cada visita sua era uma festa. Tendo sido em vida várias vezes homenageado, como quando recebeu o convite para ser patrono do Grêmio Juvenil de Cultura, da Biblioteca, em 1943. Dois anos depois em março de 1945, quando a Biblioteca inaugurou sua nova sede, no antigo palacete de Rodolfo Miranda, é feita uma nova homenagem e Lobato é convidado a ser o patrono da Biblioteca. O início do discurso feito pelo menino Arthur de Moraes César, que era também o diretor de A Voz da Infância, nos mostra o grau de proximidade que as crianças tinham com Lobato:

“Exmo. e Revmo. Sr. Arcebispo; Exmo. Sr. Representante do Dr.

Prestes Maia; Exmo. Sr. Diretor do Departamento de Cultura; Querido Monteiro Lobato; senhoras, senhores, colegas.”

Vemos que o menino apesar de utilizar as formas tradicionais de tratamento para as autoridades presentes quando se refere ao escritor o trata como “Querido Lobato”. Em muitos outros números do jornal temos desenhos, apreciações de obras, cartas enviadas por Lobato, e reproduções de cartas enviadas pelas crianças leitoras ao escritor. Enfim em todos os números do jornal, assim como nas cartas das crianças, percebe-se a admiração e o carinho que os leitores tinham pelo escritor e por sua obra.

Em um outro número do jornal, publicado em outubro de 1943, um leitor, o menino Carlos de Arruda Botelho, faz uma rima humorística com um fato contado para as crianças por Monteiro Lobato, em uma de suas visitas:

“Anedota Verdadeira

Matreiro...

Esta, de fato, ocorreu,

A um menino gaiato.

Quem conta é o nosso

Caro Monteiro Lobato

Numa farmácia de bairro,

O Boticário contente,

Corre a atender um freguês,

Inda um projeto de gente.

O menino muito sério

Com vosinha de flautim

Pede ao doutor: 'Duzentão' 
Do pó de 'Pirlimpimpim.',282

Ou mesmo quando Lobato decide transferir-se à Argentina, uma das frequentadoras da Biblioteca, chamada Baby Lomani, escreve um artigo intitulado “Será?”. Neste artigo a menina informa que Lobato havia se mudado à Argentina e além de mencionar a tristeza que todos os leitores brasileiros estão sentindo indaga sobre qual seria o motivo:

“Por que será que ele abandonou as crianças brasileiras? Por que mudou a Narizinho Arrebitado, Pedrinho a fazenda do Picapau Amarelo e todos os nossos amiguinhos? Quem sabe se Monteiro Lobato enjoouse de nós, ou não quis pão misturado com fubá? Será que é por causa disso?

O grande escritor foi a Argentina para conhecer as lindas crianças, ou porque lá não há tanta falta de pão, carne, etc.”283

Durante a leitura do jornal percebemos em muitos momentos, principalmente, após o término da Segunda Guerra que as crianças comentam a falta de artigos básicos como a farinha, a carne, entre outros, além de se referirem ao preço elevado e a baixa qualidade dos mesmos artigos. Talvez, esses comentários fossem influenciados pelo que também era veiculado na impressa de forma geral ou refletissem os comentários que as crianças ouviam em seu dia a dia. O interessante é que de certa forma a criança coloca a escolha feita por Lobato de maneira bastante dicotômica, ou o escritor enjoou das crianças brasileiras ou não agüentava mais a falta de pão.

Além de Lobato existem outros escritores e desenhistas que recebem números especiais ou mesmo uma biografia com resenhas de suas obras em $A$ Voz da Infância como: Érico Veríssimo, Tales de Andrade, Malba Tahan, Vicente Guimarães, Mary Buarque, Maria José Dupré, Belmonte, Karl May, Julio Verne, Disney e La Fontaine. Dentre estes somente Lobato, Karl May, Disney e Julio Verne aparecem com freqüência como escritores mais apreciados pelos leitores da Biblioteca. As obras de Disney editadas em álbuns coloridos pela Companhia Melhoramentos, muitas vezes estão entre as mais retiradas, assim Branca de Neve e Pinóquio aparecem por meses seguidos como obras mais retiradas. A própria

\footnotetext{
${ }^{282}$ BOTELHO, Carlos de Arruda. Anedota Verdadeira. A Voz da Infância, n. 89, nov. 1943, p. 5.
}

${ }^{283}$ LOMANI, Baby. Será? A Voz da Infância, n. 124, out. 1946, p. 6. 
diretora da Biblioteca, Lenyra Fraccaroli, analisava esse fato pela influência que o cinema tinha na escolha do livro a ser emprestado:

"O interesse por determinados livros varia segundo as circunstâncias. O cinema, por exemplo, influi na preferência de leitura. Verificamos que os livros infantis com enredos também aproveitados em filmes atraem grande número de leitores após a apresentação dessas fitas. Foi o que aconteceu nos casos de Miguel Strogoff, Robin Hood, Branca de Neve, Mulherzinhas, Pinóquio, Gulliver no país dos anões, etc. De modo geral, as obras de Disney gozam de grande estima também na forma de livros."284

Esta prática de fato deveria ser representativa, pois durante todo o ano de 1939, temos o livro Branca de Neve, de Walt Disney, entre os mais retirados ${ }^{285}$, talvez a própria Biblioteca Infantil incentivasse indiretamente essa predileção, pois tinha uma sala destinada à projeção de filmes, sendo os de Disney e de Shirley Temple os preferidos. Assim, no mesmo ambiente da Biblioteca as crianças tinham contato com as fitas cinematográficas baseadas em livros, como no caso de Heidi, estrelado por Temple, ou então filmes de Disney que depois eram publicados como livro, como Pinóquio e Branca de Neve. Da mesma forma o cinema influencia a confecção do jornal infantil, pois os próprios desenhos de Disney aparecem reproduzidos nos primeiros números ilustrando algumas colunas, assim como também o Gato Félix.

A temática de uma das obras mais lidas da Biblioteca, Winnetou também remetia às aventuras que as crianças viam nas matinês do cinema, pois seu protagonista o chefe dos Apaches passa por inúmeras situações muito semelhantes às vividas em filmes de faroeste, onde homens brancos lutam com as tribos indígenas norte-americanas. Assim, tanto o cinema influenciava na leitura de determinados livros, pois as crianças poderiam vivenciar novamente a aventura vista na tela do cinema por meio dos livros, como também deveria acontecer o contrário, as crianças se interessavam em assistir uma fita cinematográfica cuja história já conheciam por meio das publicações.

\footnotetext{
${ }^{284}$ Lenyra Fraccaroli, citada em SOARES, Gabriela Pellegrino. Semear Horizontes. Belo Horizonte: Ed. UFMG, 2007. p. 325.

${ }^{285}$ O Filme Branca de Neve de Disney foi lançado no mercado norte-americano em 1938, e foi um dos filmes que bateu recordes de público para a época. A Biblioteca Infantil projetava em sua sala de cinema essa fita, além de outras de Disney.
} 
Essa relação entre a leitura e o cinema deveria ser tão significativa que foi tema de uma pesquisa realizada pelo Laboratório de Psicologia da Faculdade de Filosofia, Ciências e Letras da Universidade de São Paulo na Biblioteca Infantil Municipal. A pesquisa sob responsabilidade da Dra. Betti Katzenstein e de Beatriz Freitas foi divulgada em um extenso artigo publicado na Revista do Arquivo Municipal, em $1941^{286}$. O artigo começa explicitando seus objetivos: as autoras pretendiam entender quais livros as crianças preferiam e quais os motivos que as levavam a escolher determinadas publicações. Outro ponto abordado no decorrer de todo o texto é a diferença entre a leitura realizada por meninos e meninas, assim como também a preocupação em definir faixas etárias para respectivas obras, para isso a pesquisa utilizou entrevistas feitas com os leitores, além das fichas de leitura, que eram preenchidas pelos frequentadores da Biblioteca Infantil. Depois de determinarem quais eram as obras literárias que haviam sido transpostas para o cinema, as autoras fizeram um levantamento nas 930 fichas de leitura preenchidas pelos frequentadores da Biblioteca, de abril de 1936 a julho de 1939. Chegaram à constatação que dois livros, cujos enredos foram adaptados para o cinema, foram os mais retirados: Mulherzinhas, de Louise May Alcott, com 100 fichas de leitura e O Rancho do Fantasma, adaptado por A. Brussolo, publicado primeiramente na Gazeta Infantil, com 104 fichas de leitura. As autoras logo perceberam uma diferença muito significativa em termos de gênero: quase a totalidade de leitores de Mulherzinhas era do sexo feminino, assim como, também, noventa por cento dos leitores de O Rancho do Fantasma era composto por meninos. Depois de procederem a uma análise material dos dois livros, assim como também de seus conteúdos, elas analisaram as opiniões das crianças sobre os livros e também sobre os personagens. Ao final as autoras avaliaram ter compreendido como as crianças viviam as aventuras de seus heróis e julgavam as personalidades dos mesmos.

Ao iniciar a pesquisa imaginávamos que teríamos acesso a todas essas fichas preenchidas pelos frequentadores, e que poderiam nos revelar a recepção de um universo bastante representativo da literatura infanto-juvenil do período. No entanto, as fichas não foram preservadas junto ao acervo histórico da instituição, e delas somente restam as citações bastante fragmentadas utilizadas no decorrer do

\footnotetext{
${ }^{286}$ KATZENSTEIN, Betti; FREITAS, Beatriz de. Algo do que as crianças gostam de ler. Revista do Arquivo Municipal, n. 77, p. 5 -87, jun/jul 1941.
} 
artigo, além das poucas fichas que foram publicadas no A Voz da Infância. Além disso, devemos lembrar que as frases e expressões que aparecem no texto foram escolhidas pelas autoras, no sentido de comprovar um determinado ponto de vista. Assim, também por terem sido feitas seguindo um determinado padrão, temos respostas muito semelhantes, pois as fichas de leitura traziam perguntas muito dirigidas e com espaço reduzido para suas repostas.

De forma geral pelo A Voz da Infância temos acesso ao universo cotidiano destas crianças. Em determinados meses do ano elas mesmo dizem estar sobrecarregadas com as avaliações e provas escolares, assim como em meses mais “folgados" encontram tempo para passeios muitas vezes feitos com os pais e parentes pelos arredores da cidade. A relação existente entre as crianças e a cidade também é outro ponto que pode ser analisado, por vezes, a cidade é hostil, com seus carros em alta velocidade, bondes e ruas movimentadas, onde poucos se conhecem. Em outros contos a cidade é mais receptiva, e a criança pode encontrar beleza, em árvores e pássaros e mesmo trabalhadores que passam pelas ruas. Um trabalho que analise a cidade pela ótica das crianças pode ser feito a partir da leitura do jornal publicado na Biblioteca Infantil.

Mas o que as crianças achavam do que liam? Pela seção "Movimento da Biblioteca” já vimos quais eram seus autores prediletos, assim como os livros que tinham mais circulação. Mas porque eram eles os escolhidos, o que eles tinham que motivavam a leitura? As resenhas, ou apreciações dos livros feitas no jornal, podem nos trazer algumas pistas para entendermos melhor a recepção da leitura literária no período estudado.

Durante o período estudado, de junho de 1936 a dezembro de 1948, encontramos várias resenhas publicadas pelos colaboradores no jornal, e algumas fichas de leitura. Como já foi dito as fichas de leitura eram solicitadas pelas bibliotecárias como forma de mapear a compreensão do livro, quando são publicadas servem principalmente para que os leitores do jornal e frequentadores da Biblioteca possam fazer as suas próprias fichas de forma satisfatória. Com o texto muito objetivo e, por vezes, superficial não nos possibilita uma compreensão mais aprofundada do tema.

Por sua vez as resenhas, que muitas vezes estão publicadas na seção intitulada “Livros Novos”, dão inúmeros indícios de quais eram os pontos que motivavam a leitura e o que havia mais agradado na obra lida. Veremos também 
que o fato de terem sido escritas por crianças teve como resultado resenhas com características muito peculiares.

Novamente Monteiro Lobato aparece como o favorito, pois é o autor que teve o maior número de obras resenhadas pelo jornal, as obras: Reforma da Natureza, A chave do tamanho e Os Doze Trabalhos de Hércules foram as escolhidas. É interessante notar que as resenhas que apareceram no jornal infantil saíram pouco tempo depois do lançamento das obras, assim percebemos que, provavelmente, as crianças frequentadoras da Biblioteca tinham acesso aos livros logo após eles terem sido lançados no mercado.

Em julho de 1941, mesmo ano da primeira edição da obra, a menina Lélia Silva Busch, de 11 anos fez a apreciação de Reforma da Natureza. A leitora inicia a resenha elogiando e qualificando a obra lida:

“Acabo de ler mais um interessante livro de Monteiro Lobato, intitulado - a Reforma da Natureza.

O autor demonstra sua imaginação fértil contando uma curiosa aventura com os já conhecidos personagens, Dona Benta, tia Nastácia, Pedrinho, Narizinho, Visconde e a danadinha da Emília.”

Já no primeiro parágrafo notamos que não era o primeiro livro de Lobato que a menina havia lido, mais do que isso ela deixa claro ser "mais um interessante livro”, assim ela inclui essa obra no rol das outras, todas elas interessantes. Logo em seguida ela diz que o autor nessa obra "demonstra uma imaginação fértil”, a leitora não explicita o porque deste comentário, no entanto, pela própria leitura da obra podemos imaginar o porquê, pois nesta obra Emília, ajudada por Rã, modificam a natureza com idéias totalmente inusitadas.

Logo em seguida a menina Lélia faz um pequeno resumo do livro:

"Depois de acabada a guerra, os ditadores europeus procuraram alguém que pudesse reformar o Velho Mundo e estabelecer definitivamente a paz. Descobriram para isso D. Benta e o seu pessoal, que imediatamente embarcaram para a Europa. Somente Emília ficou no Sítio. Após a partida da família, Emília resolveu reformar a natureza. É fácil imaginar as estrepolias que fez em companhia de sua amiga a Rã.

De volta da sua viagem, D. Benta encontrou tudo muito estranho, mas Emília explicou que tinha reformado a natureza. Algumas de suas invenções eram acertadas, como por exemplo, o apito que a panela soltava 
toda a vez que o leite estava fervendo; outras porém eram bastante desastradas.

Diante da reclamação geral feita pelos pássaros, pelas frutas, etc., a Emília não teve remédio senão desfazer suas invenções e deixar tudo no mesmo estado anterior."287

A resenha é bastante objetiva, faz um resumo do enredo e não nos dá muitas pistas sobre quais partes teriam agradado mais a jovem leitora. Ela descreve somente uma mudança que Emília tinha feito, que em sua opinião era “acertada” pois tinha uma razão prática de ser. Qualificando as mudanças feitas por Emília e Rã como “estrepolias”, isto é bagunças, nos indica que talvez fosse exatamente esse o interessante da obra. Provavelmente, para a leitora, Lobato utilizou-se de sua imaginação fértil justamente para criar mudanças insólitas, inesperadas e por isso engraçadas na natureza. O livro também se torna mais interessante, pois os leitores poderiam se identificar com a Rã, menina amiga de Emília, que como vimos era uma das leitoras que havia se correspondido com Lobato. Quem não gostaria de visitar o Sítio e aprontar grandes reinações junto com Emília? Talvez o sucesso da obra fosse, em certa medida, resultado dessa imensa liberdade que a criança podia experimentar identificando-se com um dos protagonistas.

Na resenha feita pelo menino Milton Oscar Szente, de nove anos, do livro A Chave do Tamanho, publicada em fevereiro de 1943, poucos meses depois de seu lançamento em 1942, as opiniões sobre a obra aparecem de forma mais acentuada. Logo no início o leitor diz:

"Esta, julgo eu, foi a melhor obra de Monteiro Lobato.

Nesse livro, Lobato prende a atenção irresistivelmente, não só das crianças como de pessoas grandes.”

Assim para o menino Milton esta seria a melhor obra de Lobato, novamente vemos que não era o primeiro livro do autor que ele lia, uma das qualidades apontadas por ele seria de que o livro "prende irresistivelmente" a atenção dos leitores, sendo eles crianças ou adultos. Assim como a menina Lélia, Milton ressalta as peraltices feitas pela boneca:

"Nesse livro, Emilia faz as suas diabruras pelo mundo a fora”

\footnotetext{
${ }^{287}$ BUSCH, Lélia Silva Kuntz. Apreciação do livro a Reforma da Natureza. A Voz da Infância, n. 61, jul. 1941, p.2.
} 
Ouvindo D. Benta falar horrores da guerra, resolve acabar com ela, mas ... quase acaba com o gênero humano, pois transforma os homens em minúsculos seres e a ela também.

Enfrenta grandes perigos, tais como: quando enfrenta um grande pinto sura, fato esse que causa uma grande modificação na sua vidinha, pois impede-a de entrar no sítio.”

A resenha de Milton comenta o enredo da obra, mas provoca a curiosidade do leitor, pois não nos revela o final da obra. Além disso faz considerações que também estimulam a leitura:

“Tem a 'Chave do Tamanho’ a teoria da relatividade, de modo que o leitor quando acaba a leitura, sabe muito mais de relatividade do que pensa."

Dessa forma, mesmo as crianças que preferem obras não tão fantasiosas e onde o aprendizado de certos conteúdos ligados às matérias escolares aparece com mais força, se sentem atraídas a ler o livro.

O final da resenha é peculiar:

“Quem ler esse livro, nem quer ouvir falar da palavra guerra!”288

A terceira resenha de um livro de Lobato é feita em dezembro de 1944, mesmo ano da primeira edição de Os doze trabalhos de Hércules, obra que foi publicada inicialmente em doze livros curtos, cada qual contando uma das aventuras presenciadas, por Pedrinho, Emília e Visconde. A resenha foi feita por José Arthur Giannotti, frequentador da Biblioteca com catorze anos, e inicia contando como Lobato concebeu a obra:

"Monteiro Lobato acaba de escrever 12 livros novos, intitulados 'Os doze trabalhos de Hércules'. Eles falam sobre os trabalhos que o maior herói do mundo antigo realizou. Em certos volumes, como tornarse-ia enfadonho o assunto, Lobato sacrifica um pouco a lenda, cortando-a com as peripécias dos ‘picapaus’, para retomá-la novamente.

Agradecemos a maravilhosa idéia do nosso escritor e pedimos que escreva mais sobre mitologia helena, essa mitologia de imaginação e poesia."

\footnotetext{
${ }^{288}$ SZENTE, Milton Oscar. Apreciação sobre a Chave do Tamanho. A Voz da Infância, n. 80, fev.
} 1943, p. 4. 
José Arthur nessa resenha pouco fala sobre o enredo da obra, assim como também não a qualifica, prefere tecer comentários sobre a importância da mitologia grega:

“A mitologia helena é a mais bela do universo, pois revela um sentimento verdadeiro que existe nos corações humanos. Começou rude, vinda de pastores humildes, mas evoluiu, indo abrigar-se nos domínios das Musas, lá no Hélicon, para viver eternamente lembrando que o coração tem poesia”,289

Talvez desta forma o menino José Arthur estimule a leitura do livro pelo assunto que ele aborda. Devemos lembrar que, ainda na década de 40, o ensino de línguas clássicas e de uma história antiga mais detalhada era freqüente em todas as escolas, assim o assunto do livro fazia também parte do conteúdo trabalhado em sala de aula. É interessante que em nenhum momento o leitor se refere como os outros haviam feito as asneiras ou estripolias feitas por Emília, unicamente se limita a dizer que "Lobato sacrifica um pouco a lenda, cortando-a com as peripécias dos picapaus”, em seu modo de ver por que o assunto se tornava enfadonho. Ao compararmos essa resenha com as duas outras já comentadas vemos que existe uma diferença não só na forma pela qual ela foi feita, mas também em seu conteúdo. Provavelmente essa diferença possa se justificar pela idade de cada um dos resenhistas, nas duas primeiras temos onze e nove anos, enquanto que a idade de José Arthur é de catorze anos. Sendo assim essa última resenha é mais séria e parece querer mostrar já um certo domínio de conteúdos mais "adultos".

Por estas três resenhas das obras de Lobato temos poucos indícios de como era a recepção literária. Percebemos que as obras de Monteiro Lobato são muito apreciadas, mas os leitores não explicitam o porquê de gostarem tanto de sua obra. Somente na apreciação de Milton é que ficamos sabendo um pouco mais Por exemplo, que o leitor considera o livro envolvente, pois ele "prende a atenção”. Os leitores também comentam a personagem Emília, suas peraltices e diabruras, mas o fazem com um certo comedimento se comparadas às cartas que as crianças enviavam para o escritor. Aqui talvez tenhamos uma das grandes diferenças entre as resenhas e as cartas: o humor e a diversão que a leitura

${ }^{289}$ GIANNOTTI, José Arthur. Livros Novos. A Voz da Infância, n. 102, dez. 1944, p. 13. 
proporciona não tem tanto lugar nas resenhas. Não que ele não existisse no âmbito da leitura, provavelmente existia, mas as crianças não deixam explícito isso como uma característica importante da obra, talvez porque estivessem escrevendo para outras crianças ou porque o ambiente do jornal e da Biblioteca fossem mais sérios, a leitura é vista como algo que instrui, ou que deveria servir a isso, e não somente para o prazer e o divertimento. Isso fica evidente em alguns textos produzidos pelas crianças, como no artigo “Até eles!” escrito por Bento Carlos de Arruda Botelho, de dezesseis anos. Neste texto, o leitor, diz que tendo ido à Biblioteca Municipal, viu alguns poucos consulentes lendo e anotando assuntos variados, mas um senhor mais velho chamou sua atenção, pois tinha uma aparência bem cuidada e lia de “cenho carregado” uma brochura. Várias hipóteses passaram pela cabeça do jovem: seria um livro de alta matemática, uma descrição do Tibet ou outros assuntos de grave significado. No entanto quando o senhor termina sua leitura e vai a procura de outro nas estantes, o menino aproveita:

“Chegara a grande oportunidade! Fechei o meu livro e me dirigi para a mesa, preparado para ler qualquer nome arrevezado. Mais tarde dissiparei minhas dúvidas numa enciclopédia.

Ligeiro me aproximei, curvei-me sobre o livro, e... seria possível? Pisquei repetidamente. Olhei de novo. Não havia dúvidas, era um banalíssimo romance policial, cujo nome não convém figurar aqui." 290

A citação e mesmo o título nos mostram que a leitura de certos livros era marcada pelo preconceito, e julgada inferior às outras leituras. Assim como a menina Lygia Caropreso, que aconselhava as crianças a ler, mas a lerem os livros apropriados, o menino Bento se decepciona ao constatar que até mesmo os adultos liam obras consideradas não muito adequadas, como os romances policiais, que ele se faz questão de nem citar o nome.

Percebemos então que a leitura era incentivada pelas resenhas, artigos e até mesmo caricaturas feitas em $A$ Voz da Infância, mas não qualquer tipo de literatura. As obras deveriam ajudar a construir bons indivíduos, cidadãos para a nação, incutir nas crianças valores corretos. O prazer e a diversão que a leitura

\footnotetext{
${ }^{290}$ BOTELHO, Bento Carlos de Arruda. Até Eles! A Voz da Infância, n. 88, out. 1943, p. 5.
} 
poderia trazer parecem não vir em primeiro lugar, e muito frequentemente não são sequer mencionados.

Se livros como os romances policiais eram mal vistos por algumas crianças, o que dizer então das histórias em quadrinhos, os famigerados Gibis, que tanto atraíam os meninos e jovens das décadas de 40 e 50. A preocupação com o que as crianças estavam lendo era tão importante que inúmeros artigos em jornais e revistas da época comentavam essas leituras, e a influência que poderiam exercer nesse público ainda em formação. Temos como exemplo a matéria “A literatura de guerra é a preferida no momento", publicada pelo A Noite, jornal paulistano em 2 de dezembro de 1943. Nessa matéria temos uma pesquisa feita em livrarias da cidade, onde os volumes mais vendidos para jovens e adultos diziam respeito aos acontecimentos da Segunda Guerra Mundial, paralelamente a isso é veiculada uma entrevista de Lenyra Fraccaroli, onde ela conta um pouco sobre a organização da Biblioteca Infantil e o que as crianças preferem na instituição que ela dirigia. A reportagem tende a mostrar os romances policiais, assim como os relatos de guerra como prejudiciais ao desenvolvimento infantil, em virtude sobretudo das descrições de cenas violentas. Se esses livros eram condenados os Gibis eram ainda mais, pois ultrapassavam o relato escrito mostrando visualmente as cenas de crimes e violência, além de mostrar o corpo feminino praticamente desnudo.

A preocupação com o que as crianças liam aparece com bastante destaque com a organização dos Congressos Infanto-juvenil de Escritores. O primeiro realizado em São Paulo em 1946, o segundo em Belo-Horizonte em 1947 e o terceiro no Rio de Janeiro em 1948. Nesses Congressos as crianças escreviam e apresentavam diversas teses, todas elas relacionadas a literatura infanto-juvenil, por exemplo: em sua terceira edição o Congresso debateu a influência que a leitura de Gibis acarretava nas crianças. De fato, essa preocupação não era exclusividade das crianças, pois durante o período a imprensa e educadores debateram com bastante veemência as conseqüências que esse tipo de leitura poderia trazer as crianças e jovens. Gonçalo Junior aborda essa perseguição empreendida por parte da imprensa às histórias em quadrinhos, em seu livro $A$ guerra dos Gibis. ${ }^{291} \mathrm{O}$ autor mostra como a violência era sim um dos pontos mais

291 GONÇALO JUNIOR. A Guerra dos Gibis: a formação do mercado editorial brasileiro e a censura aos quadrinhos, 1933-64. São Paulo: Companhia das Letras, 2004. 
criticados por educadores, no entanto, a acusação de que os quadrinhos desnacionalizavam as crianças e jovens, incutindo em suas mentes hábitos e valores sobretudo norte-americanos era também um forte argumento que os opositores dos quadrinhos utilizavam.

Toda essa polêmica sobre as histórias em quadrinhos havia nascido na Europa, notadamente em solo italiano e francês, durante a década de 30, a principal acusação de religiosos, educadores e literatos era de que os quadrinhos além de desnacionalizarem as crianças, importando hábitos norte-americanos, incitavam a violência sendo um dos principais fatores do aumento da delinqüência juvenil. Já no final dessa década começaram a surgir oposicionistas também em solo norte-americano, por conseguinte, as críticas se voltavam para a violência e para a influência que os quadrinhos teriam nos sentido de afastar as crianças da literatura propriamente dita. Pois, como teriam um apelo visual grande e frases fáceis de serem lidas faziam com que meninos e meninas não se tornassem leitores de fato.

Todos esses argumentos estavam presentes nas discussões do terceiro Congresso Infanto-Juvenil de Escritores, realizado no Rio de Janeiro. Percebemos pela leitura dos discursos e teses apresentados que as crianças estavam atentas ao debate veiculado nos jornais e revistas. Assim, podemos inferir que as crianças tinham acesso e liam a imprensa adulta, tirando dela muitos argumentos utilizados em suas falas.

Enquanto a violência explícita dos Gibis recebia inúmeras críticas, autores literários que também se utilizavam dela aliada às cenas de ação e aventura eram os mais lidos da própria Biblioteca Infantil Municipal. Era o caso de Karl May um dos autores mais procurados pelas crianças, sobretudo pelos meninos, que liam com furor as aventuras passadas em terras exóticas, onde o herói era sempre um bravo guerreiro com nobres ideais, como Winnetou, cacique dos apaches. Karl May (1842-1912) foi um dos autores alemães mais vendidos em todos os tempos. Publicado no Brasil pela Editora Globo sua obra de mais sucesso foi Winnetou, romance de aventura em três volumes que relatava as lutas do chefe dos apaches contra homens brancos traiçoeiros e maus.

Essa obra esteve durante anos na lista das mais retiradas da Biblioteca Infantil e em abril de 1943 recebe uma resenha em A Voz da Infância. A resenha escrita por Kleber M. Dória, de quinze anos, se inicia com a descrição do livro: 
"Winnetou é o livro que inicia a série de obras de Karl May. É uma obra em três volumes, não muito pequenos, cheios de aventuras, emoções e heroísmos, etc.

Tem por cenário as planícies bravias do oeste dos Estados Unidos.”

O menino destaca aqui o que o leitor irá encontrar no livro: aventuras, emoções e heroísmos, para em seguida tecer um comentário inusitado sobre a forma literária:

“A obra em português não é grande coisa sob o ponto de vista literário, pois é uma tradução”

Na concepção do menino as traduções sempre esvaziariam o conteúdo literário? Como não pudemos determinar qual seria a edição lida por Kleber não conseguimos averiguar se de fato a tradução foi mal feita. Contudo, é interessante notar que o leitor escolheu mencionar o fato de ser a obra lida uma tradução e de ressaltar não ter ela um valor literário muito importante. Talvez não fosse somente o fato de ser uma tradução que a esvaziasse do ponto de vista literário, mas uma característica intrínseca desse gênero ou autor.

Logo em seguida o leitor faz algo inusitado para uma resenha, não só conta o final e clímax da obra, mas também faz questionamentos sobre ela:

“Aqueles que esperavam a vitória final do herói (Winnetou) sofrem uma desilusão, pois em um dos últimos capítulos ele falece prostado por uma bala.

Uma coisa porém eu não compreendi, o que aliás não se deu apenas comigo, pois vários amigos toparam com essa dúvida.

Essa dúvida que paira sobre esses leitores de Winnetou é a seguinte:

O varonil cacique dos apaches vem a falecer como já disse em linhas acima, mas... depois esse mesmo ídolo dos peles vermelhas da terra de Washington vive outras aventuras nos outros livros de Karl May.

Para sanar essa dúvida eu formulei uma hipótese: os outros livros de Karl May foram escritos ao mesmo tempo que escreve os volumes de Winnetou.

Vocês que já leram esse livro podem avaliar se eu estou ou não com a razão. 
É um dos melhores livros de Karl May e um dos melhores livros de aventuras."292

Nessa resenha temos uma linguagem muito diferente das utilizadas pelas outras crianças já mencionadas. Em primeiro lugar o menino Kleber escreve e dialoga diretamente com o leitor do jornal, não se esquivando de dar sua opinião pessoal sobre o livro lido. Em um primeiro momento pode parecer pueril ele contar o final da história, relatando a morte do herói. No entanto contar o desfecho se justifica nessa resenha porque o que o menino pretende, em última instância, é analisar o conjunto da obra de Karl May, resolver um impasse que é o dos livros publicados a posteriori contarem histórias de um herói falecido no primeiro livro. É interessante analisar o fato de que a verossimilhança é cobrada pelo leitor, que utiliza uma estratégia bastante interessante para adequar as obras do mesmo autor. Também nas cartas dirigidas a Lobato notamos que um dos pontos que mais chamam a atenção dos leitores infantis é o apego a verossimilhança, a obra pode abusar da fantasia, mas deve ser fiel ao que propõe.

O mesmo menino Kleber fez também uma segunda resenha em julho de 1943, desta vez da obra Kim, de Rudyard Kipling. A resenha começa com uma descrição elogiosa do livro:

"Kim é um livro de aventuras que nos mostra a vida de um menino na velha Índia colonial inglesa. Esse menino se chama Kim, daí o nome desse estupendo volume de Kipling.

Classifiquei Kim como sendo o primeiro dentre os muitos livros de aventuras que já li.”

Depois de qualificar o livro, como sendo o melhor já lido, no gênero de aventuras, Kleber passa a fazer um pequeno resumo da obra. Mas dessa vez não nos conta o que acontece no final, instigando a curiosidade do leitor:

“(...) nas primeiras férias que tem Kim desaparece e sabe vocês o que faz? Faz a Índia ficar de cabelos brancos.

Leiam o livro e vejam o que faz o terrível Kim.”293

As duas resenhas feitas por Kleber M. Dória abordam livros de aventuras, onde os heróis passam por situações arriscadas, cheias de ação e suspense. O enredo, a história, é o que chama a atenção do leitor. Em outras resenhas as

${ }^{292}$ DÓRIA, Kleber M. Winnetou. A Voz da Infância, n. 82, abr. 1943, p. 6.

${ }^{293}$ DÓRIA, Kleber M. Kim. A Voz da Infância, n. 85, jul. 1943, p. 2. 
crianças se preocupam em analisar a linguagem e também os aspectos materiais do livro como o tamanho da letra e ilustrações. É o caso da resenha de Milton Szente, de 11 anos, do livro Os Três Mosqueteiros:

“Outro livro novo, muito interessante é 'Os Três Mosqueteiros'.

Não não tenham medo; não é o de Alexandre Dumas... é uma adaptação, adivinhem de quem? Do nosso amigo Mário Donato.

Com muitas gravuras, em linguagem clara é um dos melhores livros que já li."294

Nesse comentário percebemos que o fato de ser uma adaptação é considerado pelo menino uma qualidade do livro, pois parece que a leitura do clássico não era muito encorajadora. Além disso, ele destaca que a linguagem é clara e que o uso de gravuras faz o livro ser mais atrativo. Alguns meses depois a menina Lélia Silva Kuntz Busch faz um comentário dos três livros de Maria José Dupré, O Cachorrinho Samba, A montanha Encantada e A Ilha Perdida. Nesses comentários é também a linguagem que chama a atenção da autora:

"Eis mais um interessante livro contando a vida de um cachorrinho inteligente e vivo. Escrito em linguagem simples, com inúmeras ilustrações e impresso em tipos grandes muito legíveis, certamente encantará a pequenada de 9 e 10 anos.”

“A 'Montanha Encantada' encerra aventuras irreais mas bem interessantes. Os fans deste livro variarão entre 9 a 13 anos, sendo como é a linguagem simples e o enredo emocionante de lindas aventuras de férias”

E sobre A Ilha Perdida:

“No estilo, por alto naturalmente, de Monteiro Lobato, é leitura cativante que certamente agradará a jovens de 10 a 13 anos.

Aventuras de crianças, sempre agradarão aos pequenos leitores. Fundo real e com ilustrações é de se esperar êxito também nos livros infantis de Sra. Leandro Dupré."295

Em todos os livros de Maria José Dupré a leitora aponta uma linguagem simples e de fácil acesso, mesmo aos menores, chega mesmo a compará-la a Monteiro Lobato. Mas toma o cuidado de usar uma expressão “por alto

294 SZENTE, Milton. Os três Mosqueteiros. A Voz da Infância, n. 104, fev. 1945, p.17.

${ }^{295}$ BUSCH, Lélia Silva Kuntz. Comentário de Livro. A Voz da Infância, n. 112, out. 1945, p. 18. 
naturalmente”, quase como dissesse que Lobato era inimitável. É interessante notar que também considera o enredo de A Montanha Mágica irreal, ou seja fantasioso demais, como contraponto considera que A Ilha perdida tem "fundo real”. Assim como Milton Szente tece considerações sobre o aspecto material da obra, como as ilustrações, sempre presentes e mesmo a impressão em tipos maiores, facilitando a leitura.

Pelas resenhas analisadas acima percebemos que os pontos abordados pelas crianças leitoras em muitos aspectos se aproximam das questões levantadas pelos leitores que se correspondiam com Lobato. Algumas questões dizem respeito ao enredo, a história propriamente dita, ou seja a criatividade em escrever sobre temas inexplorados, ou inéditos, a história é tanto melhor quanto mais envolvido o leitor fica com a leitura. No mesmo sentido a forma, principalmente a linguagem utilizada pelo escritor deve ser simples, possibilitando uma leitura fluente, daí a valorização dos livros de Lobato e também de Maria José Dupré. No entanto, em certa medida, vemos que as resenhas e comentários a cerca de livros feitos no jornal não apontam para um dos pontos mais importantes mencionados pelas cartas, como o humor, a diversão e o prazer advindos da leitura. Sobre isso podemos pensar de duas formas, talvez complementares, ou os leitores/escritores de $A$ Voz da Infância pressupunham que isso era óbvio, não sendo necessário escrever sobre, ou então pelo contrário não se fala explicitamente nele pois o objetivo maior e mais nobre da leitura não seria esse. Seguindo essa última forma de pensar a Biblioteca não seria um lugar única e exclusivamente de deleite e sim de instrução e conhecimento, o jornal publicado por seus frequentadores era um veículo para a propagação de uma determinada forma de leitura. Apesar disso o jornal não é totalmente isento de bom humor e diversão, mas estas parecem estar sempre relacionadas aos passatempos como as cartas enigmáticas e palavras cruzadas e as tiras humorísticas e histórias em quadrinhos. 


\section{Considerações Finais}

Em um texto escrito em 1934, Lucia Miguel Pereira, romancista e crítica literária, aborda a diferença existente entre as maneiras pelas quais um livro pode ser lido:

“Há livros que se lêem, e há livros que se vivem. Não sei bem em que residirá essa diferença, mas é sensível; talvez esteja na qualidade da emoção que comunicam, mais intelectual nos primeiros, nos últimos mais direta, mais elementar, isto é influindo nos elementos, nas fontes da sensibilidade.(...),296

Segundo a autora às crianças somente interessa a segunda categoria, os livros onde possam residir, nos quais elas se identificam ou se tornam amigas dos personagens, vivenciando cada ação praticada por estes, como se fossem elas próprias os protagonistas da história. Tanto em romances de aventuras como em contos de fadas os pequenos leitores solidarizam-se com o herói, entusiasmam-se com os lances de bravura e dão boas risadas com situações inusitadas ou com as estratégias inventadas para a superação de algum obstáculo. Os elementos de fantasia e imaginação são aceitos com naturalidade, pois para a criança o mundo ao seu redor é repleto de possibilidades. Ainda é Lucia Miguel Pereira que ao analisar um livro de contos de fadas nos diz:

“Todo o deslumbramento, todo o imprevisto, todo o infinito do universo infantil encontram-se nessas histórias onde o maravilhoso e o quotidiano se sucedem sem transição aparente. Aquilo que faz a riqueza das crianças e dos poetas - a aceitação plácida do extraordinário, e a surpresa ante o que, a nós outros, parece natural - torna encantador o ambiente do livro"297

A documentação pesquisada: cartas, resenhas, fichas de leituras e artigos produzidos pelas crianças nos indicam que essa característica, a junção do maravilhoso com o quotidiano, era que fazia da obra de Lobato e de outros

\footnotetext{
${ }^{296}$ PEREIRA, Lúcia Miguel. Para as Crianças. In: A leitora e suas personagens. Seleta de textos publicados em periódicos (1931-1943) e em livros. Rio de Janeiro: Graphia, 1992. p. 245.

${ }^{297}$ Idem. P. 246.
} 
autores muito lidos no período um refúgio seguro, um local onde quisessem habitar. Vimos, principalmente, pela correspondência trocada entre os leitores e Lobato que de fato o autor conseguiu atingir seu objetivo, criando livros onde as crianças quisessem morar. Mais do que isso, conseguiu também por meio de sua obra divulgar idéias e valores que muitas vezes eram discutidos, principalmente pelos maiores, jovens que já pensavam em transformar a realidade.

A bibliografia sobre Lobato, repetidas vezes, menciona ter sido ele um pioneiro na área da literatura para crianças, no contexto nacional. No entanto, percebemos pela pesquisa que, antes mesmo da década de 20, havia uma considerável produção de obras de literatura infanto-juvenil. Essas obras eram, sobretudo, clássicos que haviam sido traduzidos e publicados por algumas importantes editoras do período, como a Laemmert, a Francisco Alves e a Pedro Quaresma. Além dessas traduções, muito autores consagrados por sua produção para adultos também escreveram para crianças como: Júlia Lopes de Almeida, Olavo Bilac, Coelho Neto, entre outros. Contudo, apesar dos diversos trabalhos mencionados no decorrer desta tese, essa ainda é uma área que comporta diversas investigações. Assim como também o universo da publicação de revistas destinadas ao público infantil merece um estudo aprofundado, durante a pesquisa foram encontrados títulos que não são analisados pela bibliografia, como as revistas O Picapau, O Beija-flor, Juquinha e O Polichinelo.

Não tendo sido o primeiro, Lobato, parece sim ter criado um universo totalmente inovador com suas obras para as crianças. Nelas as personagens tinham autonomia e a liberdade de pensar por conta própria, viviam em um mundo onde sacis, yaras e demais seres autóctones conviviam com as fadas e princesas vindas de outras paragens, assim como com personagens originários das histórias em quadrinhos e do cinema. Essa parece ter sido a fórmula do incrível sucesso alcançado por suas obras. Lobato ao escrever a saga do Sítio do Picapau Amarelo fazia, enfim, uma produção nitidamente nacional, reelaborando lendas e mitos de origem cabocla, assim como também contos e histórias provenientes de narrativas européias. Como se não bastasse, o escritor conseguia falar de um mundo natural muito rico, a mata, seus barulhos e mistérios, assim como não deixava de mencionar o universo das novas descobertas tecnológicas. Mesmo sendo crianças ligadas a um ambiente rural, onde a natureza estava sempre presente, Pedrinho e Narizinho tinham contato com o rádio, o cinema e os 
desenhos animados. Essa mistura de diversos aspectos que, em certa medida, compunham uma determinada identidade para as crianças brasileiras daquele período, fazia com que meninos e meninas de todas as idades aceitassem o convite para viver no Sítio, e o elegessem como lugar onde gostariam de morar para sempre.

Aliado a esses elementos, Lobato, parece também ter conseguido elaborar uma linguagem acessível à criança, pelo menos é essa a característica mais mencionada nos pareceres que as crianças elaboraram tanto nas cartas como em $A$ Voz da Infância. Essa característica fazia com que crianças que acabavam de ser alfabetizadas pudessem ler sem muitas dificuldades seus livros, e como elas mesmo mencionam, depois de se tornarem hábeis na leitura todo um mundo se abria para elas. Dessa forma a leitura das aventuras de Narizinho, Pedrinho, Emília e Visconde faziam com que as crianças enveredassem por leituras diversas. Muitos dos autores de sucesso no período hoje em dia estão praticamente esquecidos ou permanecem na lembrança de poucos, como no caso de Karl May. O porquê desta impermanência merece ser investigado, um dos pontos importantes parece ser o da linguagem, obras produzidas há quase um século utilizavam-se de uma construção muito diferente, atualmente essa construção, se não impossibilita, torna enfadonha a leitura de crianças e jovens.

Os escritos produzidos pelas crianças, cartas e artigos, revelaram-nos no decorrer da pesquisa a autonomia de pensamento que possuíam, quando lhes era dada a oportunidade de se expressar, e quando também possuíam interlocutores atentos, que valorizavam suas opiniões. Mais que isso, mostraram que as crianças, ao participar de uma cultura, reelaboram significativamente seu conteúdo, criando novas possibilidades de se pensar a literatura e também o mundo a seu redor. 


\section{Fontes}

Instituto de Estudos Brasileiros. Universidade de São Paulo. IEB/USP: Arquivo Raul Andrada e Silva. Dossiê Monteiro Lobato.

- Correspondência Passiva:

- Cartas Infantis

- Cartas Adultas

- Correspondência Ativa

- Documentos Pessoais

Biblioteca Monteiro Lobato. BML/PMSP. Seção de Bibliografia e Documentação:

- Documentação da Biblioteca Monteiro Lobato. Álbuns organizados por Lenyra Fraccaroli (1936 a 1954)

- Jornal “A Voz da Infância” (1936 a 1948)

- Atas das reuniões da diretoria do jornal “A Voz da Infância”

- Documentação sobre os Congressos Infanto-Juvenis de Literatura.

- Correspondência Ativa e Passiva de Monteiro Lobato

- Correspondência Ativa e Passiva de Lenyra Fraccaroli

- Correspondência dos frequentadores da Biblioteca

- Cadernetas pessoais de Monteiro Lobato

- Livros antigos e obras raras de literatura infantil.

- Revistas infantis:

- “O Picapau” (1908)

- “Juquinha” (1912)

- “O Beija-Flor” (1915-1918)

- “O Polichinello” (1917-1918)

- “O Tico-Tico” (1911-1951)

- “Vida Infantil” (déc. 40 e 50)

Arquivo do Centro de Estudos e Documentação Alexandre Eulálio. CEDAE/UNICAMP. Fundo Monteiro Lobato:

- Correspondência Ativa e Passiva 


\section{Bibliografia}

\section{Obras literárias}

ALENCAR, José de. Como e porque sou romancista. São Paulo: Pontes, 1990.

ALENCAR, José de. Obras. Rio de Janeiro: Aguillar, 1989,

ALMEIDA, Júlia Lopes; VIEIRA, Adelina. Contos infantis em versos $e$ prosa. Adaptados para o uso das escolas primárias no Brasil. 8.ed. Rio de Janeiro; São Paulo: Laemmert, 1910.

BARRETO, Lima. Obra Completa. São Paulo: Brasiliense, 1956.

BILAC, Olavo; BOMFIM, Manoel. Através do Brasil: Prática da língua portuguesa. Narrativa. Organização e Introdução de Marisa Lajolo. São Paulo: Companhia das Letras, 2000.

BROCA, Brito. A vida literária no Brasil - 1900. Rio de Janeiro: José Olympio, 1975.

BROCA, Brito. Horas de Leitura. Campinas: Unicamp,1992.

CAVALHEIRO, Edgard. A correspondência entre Monteiro Lobato e Lima Barreto. Rio de Janeiro: MEC/Serviço de Documentação, 1955. Caderno de Cultura, 76.

DAUDET, Aphonse. Aventuras Prodigiosas de Tartarin de Tarascon. São Paulo: Saraiva, 1959.

LISPECTOR, Clarice. Felicidade Clandestina. Rio de Janeiro: Rocco, 1998.

MONTEIRO LOBATO, José Bento. Obras Completas. São Paulo: Ed. Brasiliense, 1957. 30 vols.

MEIRELES, Cecilia. Inquérito realizado nas escolas do Distrito Federal sobre a literatura infantil. Belo Horizonte: Departamento de Educação, 1934. $12 \mathrm{v}$.

MEIRELES, Cecilia. Problemas da literatura infantil. 3 ed. Rio de Janeiro: Nova Fronteira, 1984.

PEREIRA, Lucia Miguel. A leitora e seus personagens. Rio de Janeiro: Graphia, 1992.

QUINTANA, Mário. A vaca e o hipogrifo. 4 ed. Porto Alegre: LPM, 1983.

RIO, João do. O momento literário. Rio de Janeiro/ Paris: Garnier, s.d.

ROMERO, Sílvio. História da literatura brasileira. 3 ed. revista e aumentada. Rio de Janeiro: José Olympio, 1943.

TEIXEIRA, Anísio. Conversa entre amigos: correspondência escolhida entre Anísio Teixeira e Monteiro Lobato. Salvador/ Rio de Janeiro: Fundação Cultural do Estado da Bahia/ Fundação Getúlio Vargas/ CPDOC, 1986. 


\section{Memórias, Crônicas e Biografias}

AMERICANO, Jorge. São Paulo naquele tempo. 1895/1915. São Paulo: Saraiva, 1957.

AMERICANO, Jorge. São Paulo nesse tempo. 1915/1935. São Paulo: Melhoramentos, 1962.

BILAC, Olavo. Julio Verne, o bonde, o burro e outros escritos. São Paulo: Ed. Barcarolla, 2004.

BOSI, Ecléa. Memória e Sociedade: lembranças de velhos. São Paulo: T. A. Queiroz, 1979.

BRANCO, Frederico. Postais paulistas. São Paulo: Maltese, 1993.

BARROS, Maria Paes de. No tempo de Dantes. 2 ed. São Paulo: Paz e Terra, 1998.

BROCA, Brito. Memórias. Texto organizado, anotado e com introdução de Francisco Assis Barbosa. Rio de Janeiro: Livraria José Olympio, 1968.

BELINSKY, Tatiana. Transplante de menina: da rua Navios à rua Jaguaribe. Rio de Janeiro: Agir, 1989.

CAMARGOS, Márcia. Juca e Joyce: memórias da neta de Monteiro Lobato. São Paulo: Moderna, 2007.

CAVALHEIRO Edgard. Monteiro Lobato: vida e obra. São Paulo: Nacional, 1956. 2v.

DUPRÉ, Maria José. Caminhos. São Paulo: Saraiva, 1969.

GATTAI, Zélia. Anarquistas graças a Deus. 10 ed. Rio de Janeiro: Record, 1985.

HILDEBRANDO, Luís. Crônicas de nossa época. Rio de Janeiro: Paz e Terra.

MEIRELES, Cecília. Olhinhos de Gato. São Paulo: Moderna, 1983.

MORLEY, Helena. Minha vida de menina. São Paulo: Cia das Letras, 1998.

PENTEADO, Jacob. Belenzinho, 1910. Retrato de uma época. 2 ed. São Paulo: Carrenho Editorial; Narrativa Um, 2003.

RAMOS, Graciliano. Infância. 37. ed. Rio de Janeiro: Ed. Record, 2003.

TELLES, Lygia Fagundes. Durante aquele estranho chá: perdidos e achados. Rio de Janeiro: Rocco, 2002. 


\section{Bibliografia Interpretativa Sobre Lobato}

AZEVEDO, Carmen Lucia de; CAMARGOS, Márcia R. de; SACCHETTA, Vladimir. Monteiro Lobato:furação na botocúndia. São Paulo: Senac, 1997.

BARBOSA, Alaor. O ficcionista Monteiro Lobato. São Paulo: Brasiliense, 1996.

BEY, Essad. A luta pelo petróleo. Trad. Charley W. Frankie. São Paulo: Nacional, 1935.

BIGNOTTO, Cilza Carla. Personagens infantis da obra para crianças e da obra para adultos de Monteiro Lobato. Convergências e divergências. Campinas, Unicamp/IEL, 1999.

BRASIL, Pe. Sales. A literatura infantil de Monteiro Lobato ou comunismo para crianças. Salvador: Aguiar \& Souza, 1957.

CAMPOS, André Luis Vieira de. A República do Picapau Amarelo. São Paulo: Martins Fontes, 1986.

CHIARELLI, Tadeu. Um Jeca nos vernissages. São Paulo: EDUSP, 1995.

CONTE, Alberto. Monteiro Lobato: homem e obra. São Paulo: Brasiliense, 1948.

DANTAS, Paulo (org.) Vozes do tempo de Lobato. S.l.: Traço, 1982.

DANTAS, Paulo. Presença de Lobato. São Paulo: Ed. do Escritor, s.d.

DEBUS, Eliane S. D. o Monteiro Lobato e o Leitor esse conhecido. Itajaí; Florianópolis: Univali;UFSC, 2004.

HAYDEN, Rose Lee. The children's literature of José Bento Monteiro Lobato of Brazil: a pedagogy for progress. Tese de doutorado. Michigan State University, 1974.

KOSHIYAMA, Alice Mitika. Monteiro Lobato: intelectual, empresário, editor. São Paulo, T. A. Queiroz, 1982.

LAJOLO, Marisa (org.) Monteiro Lobato. São Paulo: Abril Educação, 1981. Literatura Comentada.

LAJOLO, Marisa. Monteiro Lobato. São Paulo: Brasiliense, 1985. Encanto Radical, v. 72.

LANDERS, Vasda Bonafini. De Jeca a Macunaíma - Monteiro Lobato e o modernismo. Rio de Janeiro: Civilização Brasileira, 1988.

LOPES, Eliane M. T. e GOUVEA, Maria Cristina S. Lendo e Escrevendo Lobato. Belo Horizonte: Autêntica, 1999.

LUCA, Tânia Regina de. A Revista do Brasil: um diagnóstico para a (N)ação. Tese de doutorado. São Paulo, FFLCH/USP, 1996.

MELLONI, Rosa Maria. O imaginário e o ideário de Monteiro Lobato: um estudo antropológico. São Paulo: FE/USP, 1995.

MERTZ, Hilda J. Villela et al. Histórico e resenhas da obra infantil de Monteiro Lobato. São Paulo: Brasiliense, 1996. 
NUNES, Cassiano (org.) Cartas de Monteiro Lobato a uma senhora amiga. São Paulo, s.e., 1983.

NUNES, Cassiano. Monteiro Lobato vivo... Rio de Janeiro: MPM Propaganda/ Record, 1986.

NUNES, Cassiano. O patriotismo difícil. São Paulo: s.e., 1981.

NUNES, Cassiano. O sonho brasileiro de Monteiro Lobato. Brasília, s.e., 1979.

PENTEADO, J. Roberto Whitaker. Os filhos de Lobato. O imaginário infantil na ideologia do adulto. Rio de Janeiro: Dunya ed., 1997.

SANDRONI, Laura. De Lobato a Bojunga: as reinações renovadas. Rio de Janeiro: Agir, 1987.

SEBE BOM MEIHY, José Carlos. "Pré-modernismo, modernismo ou Monteiro Lobato e o outro lado da Lua” D.O Leitura São Paulo, 12/05/1994.

STAROBINAS, Lilian. O caledoscópio da modernização: discutindo a atuação de Monteiro Lobato. Tese de doutorado. FFLCH/USP. 1995.

TRAVASSOS, Nelson P. Minhas memórias das Monteiros Lobatos. São Paulo: Edart, 1964.

VALE, Fernando Marques do. A obra infantil de Monteiro Lobato: invocações e repercussões. Lisboa: Portugalmundo, 1994.

VASCONCELOS, Zinda Maria Carvalho de. O Universo ideológico na obra infantil de Monteiro Lobato. São Paulo: Traço Ed., 1982.

YUNES, Eliana. Presença de Lobato. Rio de Janeiro: Divulgação e Pesquisa Ed., 1982.

ZILBERMAN, Regina (org.) Atualidade de Monteiro Lobato: uma revisão crítica. Porto Alegre: Mercado Aberto, 1983.

\section{Sobre a Infância e o Período}

ANDREOTTI, Azilde L. O Jornal como fonte de pesquisa. Um projeto de educação e cultura através do "A Voz da Infância” (1936-1950). Tese (doutorado em história e filosofia da educação) Unicamp, 2004.

ARIÈS, Philippe. História social da criança e da família. Rio de Janeiro: Zahar, 1979.

ARROYO, Leonardo. Literatura infantil brasileira. São Paulo: Melhoramentos, 1967.

AZEVEDO, Fernando de. A cultura brasileira.: introdução ao estudo da cultura no Brasil. São Paulo: Melhoramentos, 1956

BELUZZO, Ana Maria de Morais. Voltolino e as raízes do modernismo. (dissertação de mestrado em artes apresentada à Escola de Comunicações e Artes da Universidade de São Paulo) São Paulo, s/d. 
BENJAMIN, Walter. Obras Escolhidas. $5^{\mathrm{a}}$ ed. São Paulo: Ed. São Paulo, 1995. Vol. 1 e 2.

BENJAMIN, Walter. Reflexões sobre a criança, o brinquedo e a educação. São Paulo: Duas Cidades; Ed. 34, 2002.

BETTELHEIM, Bruno. A Viena de Freud e outros ensaios. Rio de Janeiro: Campus, 1991.

BETTELHEIM, Bruno. A Psicanálise dos contos de fadas. Rio de Janeiro: ed. Paz e Terra, 1986.

BOSI, Alfredo. História concisa da literatura brasileira. São Paulo: Cultrix, 1981.

BRITO, Mário da Silva. Antecedentes da Semana da Arte Moderna. Rio de Janeiro: Civilização Brasileira, 1964.

COHN, Clarice. Antropologia da Criança. Rio de Janeiro: Jorge Zahar Ed., 2005.

FERNANDES, Florestan. Folclore e Mudança social na cidade de São Paulo. São Paulo: Anhembi, 1961.

FREITAS, Marcos Cezar; KUHLMANN Jr., Moyses. os Intelectuais na história da infância. São Paulo: Cortez, 2002.

HALBWACHS, Maurice. A memória coletiva. trad. Laurent Leon Schaffter. São Paulo: Vértice, 1990.

HEYWOOD, Colin. Uma História da Infância. Da Idade Média à Época Contemporânea no Ocidente. Porto Alegre: Artmed, 2004.

HOBSBAWM, Eric. A Era dos Impérios. 1875 - 1914. 8.ed. Rio de Janeiro: Paz e Terra, 2003.

MANGANELLI, Giorgio. Pinóquio: um livro paralelo. São Paulo, Companhia das Letras, 2002.

NADAI, Elza. O ginásio do Estado em São Paulo: uma preocupação republicana, 1889/1896. São Paulo: Faculdade de Educação/ USP, 1987.

NEVES, Margarida de S., LOBO, Yolanda L. e MIGNOT, Ana Christina V. Cecília Meireles: a poética da educação. Rio de janeiro: Ed. PUC-RIO/ Loyola, 2001.

POSTMAN, Neil. O desaparecimento da infância.. Rio de Janeiro: ed. Record, 1999.

PROUT, Alan. The Future of Childhood. Towards the interdisciplinary study of children. Londres; Nova York: Routledge Falmer, 2005.

SAID, E. W. Cultura e Imperialismo. São Paulo: Cia das Letras, 1995.

SALIBA, Elias Thomé. Raízes do Riso. A representação humorística na história brasileira: da Belle Époque aos primeiros tempos do rádio. São Paulo: Companhia das letras, 2002.

SALIBA, Elias Thomé. Utopias Românticas. São Paulo: Brasiliense, 1991. 
SCHWARZ, Roberto. Que horas são? Ensaios. São Paulo: Companhia das Letras, 1997.

SILVA, Aracy Lopes; NUNES, Angela; MACEDO, Ana Vera L. S. (orgs.) Crianças Indígenas: ensaios antropológicos. São Paulo: Global, 2002.

SEVCENKO, Nicolau (org.) História da vida privada no Brasil. República: da Belle Époque à era do Rádio. São Paulo: Companhia das Letras, 1998. v.3.

SEVCENKO, Nicolau. Literatura como Missão. São Paulo: Brasiliense, 1983.

SEVCENKO, Nicolau. Orfeu Extático na metrópole. São Paulo, sociedade e cultura nos frementes anos 20. São Paulo: Cia das Letras, 1992.

TEIXEIRA, Anísio. Educação no Brasil. São Paulo: Companhia Editora Nacional, 1976.

\section{Sobre Epistolografia, História da Leitura e da Literatura}

ABREU, Márcia (org). Leitura, História e História da leitura. São Paulo: FAPESP, 2000.

BARTHES, Roland. Mitologias. Rio de Janeiro: Nova Fronteira, 1982.

BURKE, Peter (org). A escrita da História. São Paulo: Editora da Unesp, 1992.

CAVALLO, Gugliemo e CHARTIER, Roger. (org.) História da leitura no mundo ocidental. trad.. Fulvia M. L. Moretto. São Paulo: Ática, 1998.

CARPEAUX, Otto Maria. História da Literatura Ocidental. 2.ed. Rio de Janeiro: Ed. Alhambra, 1984. 8 vols.

CERTEAU, Michel de. A invenção do cotidiano: artes de fazer. Petrópolis: Vozes, 1994. v. 1 e 2.

CHARTIER, Roger. A Ordem dos livros. Leitores, autores e bibliotecas na Europa entre os séculos XVI e XVIII. Tradução: Mary del Priore. Brasília: ed. UnB, 1994.

CHARTIER, Roger (org.) Histoires de la lecture. Paris: Éditions de la Maison des Sciences de l'Homme, 1995.

CHARTIER, Roger. A história cultural entre práticas e representações. Lisboa/Rio de Janeiro: Difel/Bertrand, 1990.

CHARTIER, Roger. Práticas da leitura. Tradução: Cristiane Nascimento. São Paulo: Estação Liberdade, 1996.

CHARTIER, Roger. A aventura do livro: do leitor ao navegador. Conversações com Jean Lebrun. São Paulo: Unesp/Imprensa oficial, 1999.

CHARTIER, Roger e HEBRARD, Jean. Les imaginaires de la lecture. In: Histoire de l'edition française. Paris: Promadis, 1984.. 
CHARTIER, Anne-Marie e HÉBRARD, Jean. Discursos sobre a leitura. São Paulo: Ed. Ática, 1995.

COELHO, Nelly Novaes. Dicionário crítico da literatura infantil e juvenil brasileira. São Paulo: EDUSP, 1995.

COELHO, Nelly Novaes. Literatura infantil: teoria, análise, didática. $6^{\mathrm{a}}$ ed. São Paulo: Ática, 1997.

COELHO, Nelly Novaes. Panorama Histórico da Literatura Infantil/Juvenil. 3 ed. São Paulo: Quiron, 1985.

DARNTON, Robert. O grande massacre de gatos. Rio de Janeiro: Graal, 1986.

DARNTON, Robert. O Beijo de Lamourette. São Paulo: Cia das Letras, 1995.

DARNTON, Robert. Os best-sellers proibidos da França prérevolucionária. São Paulo: Cia das letras, 1998.

DEJEAN, Joan. Antigos contra Modernos. As guerras culturais e a construção de um fin de siècle. Rio de Janeiro: Civilização Brasileira, 2005

DeNEPOTI, Cláudio. Páginas de Prazer. A sexualidade através da leitura no início do século. Campinas: Ed. Da Unicamp,

DICKENS, Charles. Frauds on the fairies. in: Household words, v.8, n.184 (out.1853) In: Children's literature - the development of criticism. London: Routledge, 1990.

ELEUTÉRIO, Maria de Lourdes. Vidas de Romance. As mulheres e o exercício de ler e escrever no entresséculos. 1890-1930. Rio de Janeiro: Topbooks, 2005.

EL FAR, Alessandra. O livro e a leitura no Brasil. Rio de Janeiro: Jorge Zahar, 2006.

EL FAR, Alessandra. Páginas de Sensação. Leitura popular e pornográfica no Rio de Janeiro (1870- 1940). São Paulo: Companhia das Letras, 2004.

FADIMAN, Anne. Ex-Libris. Confissões de uma leitora comum. Rio de Janeiro: Jorge Zahar ed., 2002.

FEBVRE, Lucien et MARTIN, Henri-Jean. L'apparition du livre. Paris: Albin Michel, 1971.

FOUCAULT, Michel. "What is an author?" In: HARARI, Josue. Textual strategies: perspectives in post struturalist criticism. Ithaca: Cornell University Press, 1979.

GALBRAITH, Gretchen R. Reading Lives. Reconstructing Childhood, Books, and Schools in Britain, 1870-1920. New York: St. Martin's Press, 1997.

GALVÃO, Walnice Nogueira; GOTLIB, Nádia Battella (orgs.) Prezado senhor, prezada senhora. Estudos sobre cartas. São Paulo: Companhia das Letras, 2000. 
GAY, Peter. O Coração desvelado. A experiência burguesa da rainha Victória a Freud. São Paulo: Companhia das Letras, 1999. vol 4.

GENETTE, Gerard. Umbrales. Buenos Aires: Siglo XXI, 2001.

GOMES, Ângela de Castro (org.) Escrita de Si, escrita da História. Rio de Janeiro: Editora FGV, 2004.

GONÇALO JUNIOR. A Guerra dos Gibis: A Formação do mercado editorial brasileiro e a censura aos quadrinhos, 1933-1964. São Paulo: Companhia das Letras, 2004.

HALLEWELL, Laurence. O livro no Brasil: sua história. São Paulo: T. A. Queiroz/EDUSP, 1985.

HANSEN, Patrícia Santos. Brasil, um país novo: Literatura cívicopedagógica e a construção de um ideal de infância brasileira na primeira República. Tese (doutorado em História). Universidade de São Paulo, 2007

HUNT, Peter. Children's literature: an illustrated history. Oxford: Oxford University Press, 1995.

HUNT, Peter. (Ed.) International Companion Encyclopedia of Children's Literature. London; New York: Routledge, 1996.

LABARRE, Albert. Histoire du livre. Paris: PUF, 1979.

LACERDA, Lílian de. Álbum de Leitura: memória de vida, história de leitores. São Paulo: Ed. Unesp, 2003.

LAJOLO, Marisa. Usos e Abusos da literatura na escola. Porto Alegre: Globo, 1982.

LAJOLO, Marisa. Do mundo da leitura à leitura do mundo. São Paulo: Ática, 1993.

LAJOLO, Marisa. (org.) Monteiro Lobato. Quando o carteiro chegou. Cartões-postais a Purezinha. São Paulo: Moderna, 2006.

LAJOLO, Marisa et ZILBERMAN, Regina. Literatura infantil brasileira: histórias \& histórias. São Paulo: Ática, 1984.

LAJOLO, Marisa et ZILBERMAN, Regina. Um Brasil para crianças. São Paulo: Global, 1986.

LAJOLO, Marisa et ZILBERMAN, Regina. A Formação da leitura no Brasil. 3 ${ }^{a}$ ed. São Paulo: Ed. Ática, 1999.

LAJOLO, Marisa et ZILBERMAN, Regina. A leitura rarefeita. Leitura e livro no Brasil. São Paulo: Brasiliense, 1991.

LEÃO, Andréa Borges. Brasil em Imaginação: livros, impressos e leituras infantis. 1890-1915. Tese (doutorado em sociologia). Universidade de São Paulo, 2002

LIMA, Herman. "O Tico-Tico - Revista Pioneira de Literatura Infantil" Revista do Livro. XIII - 340: 15-25, $1^{\circ}$ trimestre de 1970.

MANGUEL, Alberto. Uma história da Leitura. São Paulo: Cia das Letras, 1999. 
MARTíNEZ, Jesus A. Martin. (dir) História de la Edicion en Espana. (18361936). [S. l.]: Marcial Pons, 2001.

MEYER, Marlyse. Folhetim: Uma história. São Paulo: Cia das Letras, 1996.

NETTO, Samuel Pfrom et al. O livro na educação. Rio de Janeiro: Primor; MEC, 1974.

PAES, José Paulo. "Por uma literatura brasileira de entretenimento" In: A aventura literária: ensaios sobre ficção e ficções. São Paulo: Companhia das Letras, 1990.

PERROTTI, Edmir. O texto sedutor na literatura infantil. São Paulo: Ícone, 1986.

PERROTTI, Edmir. Confinamento cultural, infância e leitura. São Paulo: Summus, 1990.

PRADO, Maria Ligia Coelho. América latina no século XIX: Tramas, telas e textos. São Paulo; Bauru, Edusp; Edusc, 1999.

PROUST, Marcel. Sobre a leitura. Campinas: Pontes, 1989.

RAMA, Angel. A cidade das letras. São Paulo: Brasiliense, 1985.

RICHTER, Noé. La lecture \& ses instituitions. La lecture populaire 17001918. S.l. : Éditions Plein Chant/ Bibliothèque du Maine, 1987.

RICOEUR, Paul. Tempo e narrativa. Tomo III. Campinas: Papirus, 1994.

ROSA, Zita de Paula. Tico-Tico: o mito da formação sadia. Tese de doutorado em História Social. FFLCH/USP: São Paulo, 1991.

SARTRE, Jean-Paul. Les Mots. Paris: Gallimard, 1964.

SCHAPOCHNIK, Nelson; ABREU, Márcia (org.) Cultura Letrada no Brasil: Objetos e Práticas. Campinas, Mercado de Letras, 2005.

SOARES, Gabriela Pellegrino. A Semear horizontes: leitura literárias na formação da infância, Argentina e Brasil (1915-1954). São Paulo, 2002. Tese de doutorado em história social. FFLCH/USP.

SULEIMAN, Susan et CROSSMANN, Inge (org.) The reader in the text: Essays os audience and interpretation. Princeton: Princeton University Press, 1980.

TRAVASSOS, Nelson P. Livro sobre livros. São Paulo: Hucitec, 1978.

VIANNA, Antônio Manuel Couto. João de Deus e um século de literatura infantil em Portugal. Campo Livre: Edição do Templo, 1976.

VIDAL, Diana. O exercício disciplinador do olhar: livros, leitura e práticas de formação docente no Instituto de Educação Docente do Rio de Janeiro/ Distrito Federal. (1932-1937). Tese (doutorado em história da educação) Universidade de São Paulo, 1995.

VIEIRA, Cleber Santos. Entre as coisas do mundo e o mundo dos livros: Prefácios cívicos e impressos escolares no Brasil republicano. Tese (doutorado em educação). Universidade de São Paulo, 2008.

WATT, Ian P. Mitos do Individualismo Moderno: Fausto, Dom Quixote, Dom Juan, Robinson Crusoé. Rio de Janeiro: Jorge Zahar, 1997. 
WATT, Ian P. A ascensão do romance: Defoe, Richardson e Fielding. 3.ed. São Paulo: Companhia das Letras, 1990

ZILBERMAN, Regina. Estética da recepção e história da literatura. São Paulo: Ática, 1989.

ZILBERMAN, Regina e MAGALHÃES, L.C. Literatura infantil. Autoritarismo e emancipação. São Paulo: Ática, 1987. 